UNIVERSIDADE DE SÃO PAULO

ESCOLA POLITÉCNICA

PÓS - GRADUAÇÃO EM ENGENHARIA METALÚRGICA E DE MATERIAIS

CONTRIBUIÇÃO AO ESTUDO DAS BENTONITAS DO MUNICÍPIO DE BOA VISTA ESTADO DA PARAÍBA

Adriana Almeida Silva

SÃO PAULO 
Adriana Almeida Silva

\section{CONTRIBUIÇÃO AO ESTUDO DAS BENTONITAS DO MUNICÍPIO DE BOA VISTA ESTADO DA PARAÍBA}

Tese apresentada ao Programa de PósGraduação em Engenharia Metalúrgica e de Materiais da Escola Politécnica da Universidade de São Paulo - EPUSP, como requisito parcial para obtenção do grau de Doutora em Engenharia .

Área de Concentração: Engenharia Metalúrgica.

Orientador: Prof. Dr. Francisco Rolando Valenzuela-Diaz.

São Paulo 
A Deus, pelo equilíbrio e força;

Às pessoas que dão razão à minha existência: meu marido, meu pai, minha mãe, aos meus irmãos e a todos os membros da minha família.

Dedico. 


\section{AGRADECIMENTOS}

Principalmente a Deus, pela fidelidade, pelo equilíbrio, pelo amparo, pela saúde e principalmente pela capacitação que me deu para vencer todos os obstáculos. "Tudo que tenho, tudo que sou, agradeço a ti Senhor: "Toda honra e toda glória sejam dadas a ti."

Em especial, ao meu marido Orlando, agradeço pelas orações, fidelidade, dedicação, paciência, por acreditar no meu potencial e por me estimular nos momentos mais difíceis. Agradeço acima de tudo pelo amor e apoio incondicional. Amo-o muito!

Agradeço aos meus queridos pais, sogro e sogra (Egidio e Miriam; Assis e Hilda), meus amados irmãos (Adriano e Alisson), cunhadas (Danielle e Jamuna), meus avós (José Pedro "in memoriam" e Inácia; José Egidio e Maria do Karmo), tios (as), primos (as) e Zilma pelo incentivo e compreensão. Amo muito todos vocês!

Ao professor/orientador Prof. Dr. Francisco Rolando Valenzuela-Diaz, pela oportunidade de realizar este estudo, pela orientação competente, espírito científico, pela amizade, compreensão, críticas construtivas, análise e revisão do texto, bem como pelo apoio durante o desenvolvimento dessa tese. Agradeço também pela contribuição profissional direta durante todas as etapas de minha carreira acadêmica.

À USP - Universidade de São Paulo pela oportunidade de poder cursar o Doutorado em Engenharia de Metalúrgica e de Materiais.

Aos professores do Programa de Pós-Graduação em Engenharia de Metalúrgica e de Materiais da Escola Politécnica da Universidade de São Paulo, agradeço pelo repasse de conhecimentos necessários para conclusão desta tese. Em especial aos professores Dr. Francisco R. Valenzuela-Diaz, Dr. Hélio Wiebeck, Dr. Samuel Toffoli e Dr. Pedro Buchler.

Aos meus queridos amigos da USP Dr. Guillermo Cortez e Dr. Fábio Ésper, meus sinceros agradecimentos pela ajuda prestada nas mais diversas ocasiões, pela amizade, pelo companheirismo e pelas análises realizadas nos laboratórios da EPUSP. 
À minha grande e querida amiga Dra. Graça Valenzuela, agradeço pelas orações, conselhos, fidelidade, eterna amizade, pelo companheirismo, pela dedicação, paciência, pelo incentivo e pela força. A amizade é algo raro e você é um presente que Deus colocou na minha vida!

À empresa BENTONISA - Bentonita do Nordeste S.A, agradeço por todos os recursos financeiros concedidos para desenvolvimento dessa tese e a todos os amigos que nela conquistei (Luciana, Cléia e Delânia). Em especial aos diretores Luiz Sálvio Galvão e Alexandre Dantas, por sempre acreditarem no meu potencial e incentivarem a pesquisa no Brasil. Que Deus continue abençoando-os em todos os seus empreendimentos.

Aos pesquisadores do CPTECH Jakeline, Júlia, Natan, Eládio, Alysson, Izabel e Camila agradeço pela colaboração direta nos ensaios realizados para essa tese e pelo apoio. Obrigada pela paciência e dedicação!

Aos pastores (Bezerra, Ana, Daniel, Malu, Roberto, Eneide e Roseane) da igreja INSEJEC (Igreja Nacional do Senhor Jesus Cristo). Em especial a Apóstola Rivanda agradeço pela cobertura espiritual, orações e acima de tudo por me fazer compreender que Deus é quem está no controle da minha vida, e que tudo só ocorre quando Ele quer e da forma que Ele quer, por isso temos que confiar plenamente na Sua soberania. Hoje, para mim, verdadeiramente não há nada mais importante do que estar servindo ao Senhor de todo meu coração. Obrigada Senhor, porque tu colocaste essas pessoas tão abençoadas para cuidar espiritualmente de mim!

Às minhas queridas e amadas irmãs em Cristo: Mariana, Andrezza, Ednir, Germana, Aline, Vanessa, Gesilandia, Rita Eulália e Iragilda agradeço pelo amor e pelas orações. A Jacinta agradeço pelas intercessões para a conclusão do mesmo.

A todos que de alguma forma contribuíram para o sucesso desta tese.

"Tudo posso naquele que me fortalece..."

Filipenses 4:13 


\section{RESUMO}

Contribuição ao Estudo das Bentonitas do Município de Boa Vista Estado da Paraíba

As argilas são rochas constituídas por argilominerais e por minerais acessórios, cuja estrutura cristalina permite a adsorção de cátions e ânions conferindo-Ihes propriedades físico-químicas particulares. Quimicamente os argilomineriais são formados essencialmente por silicatos hidratados de alumínio, ferro e magnésio. As bentonitas apresentam mais de 140 usos industriais, com variações particulares, seja devido ao emprego tecnológico desta argila, seja devido à origem geológica ou à composição mineralógica desta, por isso, sendo consideradas tipos especiais de argilas industriais. O termo bentonita é usado para designar uma argila com alto teor de argila esmectítica. O maior produtor mundial de bentonita são os Estados Unidos representando cerca de um terço do total da produção mundial. No Brasil, os mais importantes jazimentos de bentonitas encontram-se na Paraíba, nos municípios de Boa Vista, Cubati e Pedra Lavrada. A bentonita bruta da Paraíba é lavrada por empresas mineradoras e comercializada em grandes quantidades no próprio Estado, sendo estas destinadas a empresas que as beneficiam, ativam e posteriormente vendem para os demais mercados nacionais. Os preços da bentonita variam em função da qualidade do produto, da pureza, da função ou aplicação, e do tipo do beneficiamento e ativação a que foi submetido o minério. Considerando a expectativa de crescimento desse setor para os próximos anos, este estudo tem como objetivo complementar e atualizar dados tecnológicos existentes na literatura sobre as bentonitas do Estado da Paraíba, contribuindo com estudos tecnológicos das bentonitas da Paraíba realizados em 1976 pelo professor Dr. Pérsio de Souza Santos. Pretende-se evidenciar como estão as propriedades e os usos de 5 argilas da mina Lages após 35 anos de estudos. Para o desenvolvimento deste trabalho utilizaram-se 5 tipos diferentes de bentonitas cedidas pela empresa BENTONISA - Bentonita do Nordeste S.A. Para estas foram realizadas as caracterizações físico-químicas e mineralógicas. Através da análise dos resultados obtidos foi possível realizar algumas indicações para os usos potenciais destes materiais.

Palavras-chave: Bentonitas, Argilas, Argilas industriais. 


\begin{abstract}
Contribution to the study of bentonite in Boa Vista state of Paraíba
\end{abstract}

The clays are composed of clay minerals and accessory minerals, whose crystal structure allows the adsorption of cations giving them particular physical and chemical properties. Chemically, the argilomineriais are formed mainly of hydrated silicates of aluminum, iron and magnesium. The bentonites are special types of industrial clays because submitting more than 140 industrial uses, with particular variations, whether due to technological employment of clay, is due to the geological origin and the mineralogy of this clay. The term bentonite is used to designate a high clay content of montmorillonite. The world's largest producer of bentonite is the United States represents about one-third of total world production. In Brazil, the most important bentonite clay bentonite deposits are found in Paraiba, in the municipalities of Boa Vista, Cubati and Pedra Lavrada. The crude bentonite Paraíba is wrought by mining companies and sold in large quantities within the State, which are aimed at companies that benefit, activate and subsequently sold to other markets. Prices vary depending on the bentonite product quality, purity, function or application, and the type of processing and activation in the ore that was submitted. Considering the expected growth of this sector in the coming years, this study aims to complement existing technology and update data in the literature on bentonite clays of Paraíba State, contributing to technological studies of bentonites from Paraíba conducted in 1976 by Professor Dr. Pérsio de Souza Santos. It is intended to highlight are the properties and uses of these materials after 35 years of studies. To develop this work, we used five types of bentonite clays supplied by the company BENTONISABentonita do Nordeste S.A., For these were the physical and mineralogical characterization. By analyzing the results we achieve some indication for the potential uses of these materials.

Keyword: Bentonites, Clays, industrial clays. 


\section{LISTA DE ILUSTRAÇÕES}

Figura

Página

Figura 1 Mapa de localização de Wyoming (EUA)

36

Figura 2 Foto ilustrando os folhelhos argilosos do Fort 37 Benton, Wyoming (EUA)

Figura 3 Mapa de localização de Boa Vista - PB 38

Figura 4 Foto ilustrando os folhelhos argilosos de Boa Vista 39 $-\mathrm{PB}$

Figura 5 Foto ilustrando o inchamento das: (a) Bentonitas que incham em água; (b) Bentonitas que não incham em água

Figura $6 \quad$ Foto da frente de lavra da bentonita de Wyoming

Figura 7 llustração no mapa dos municípios de: (a) Boa Vista, (b) Cubati e (c) Pedra Lavrada

Figura 8 Mapa geológico da região da Paraíba: (a) Boa 50 Vista (b) Cubati e (c) Pedra Lavrada

Figura 9 Foto da frente de lavra em Boa Vista - PB

Figura 10 Foto ilustrando as pilhas de estoque em Boa Vista $-\mathrm{PB}$

Figura 11 Depósito da Argila Chocolate

Figura 12 Depósito da Argila Chocobofe no pátio de 56 estocagem

Figura 13 Argila Sortida no pátio de estocagem

Figura 14 Argila Bofe no pátio de estocagem 
Figura 16 Calcedônia presente na matéria-prima utilizada

Figura 17 Calcedônia retirada manualmente durante 0

60 processo

Figura $18 \quad$ Material ativado em processo de cura 62

$\begin{array}{lll}\text { Figura } 19 & \text { Processo de secagem natural } & 63\end{array}$

$\begin{array}{lll}\text { Figura } 20 \quad \text { Moinho classificador } & 64\end{array}$

Figura $21 \quad$ Localização da cidade de Boa Vista - PB no mapa 67 da Paraíba

Figura 22 Localização das minas na região de Boa Vista - PB

69

$\begin{array}{lll}\text { Figura } 23 & \text { Localização da mina Bravo }\end{array}$

$\begin{array}{lll}\text { Figura } 24 \quad \text { Localização da mina Lages } & 71\end{array}$

$\begin{array}{lll}\text { Figura } 25 & \text { Localização da mina Lagedo }\end{array}$

$\begin{array}{lll}\text { Figura } 26 & \text { Localização da mina Primavera }\end{array}$

$\begin{array}{lll}\text { Figura } 27 & \text { Localização da mina Juá } & 74\end{array}$

Figura $28 \quad$ Localização da cidade de Cubati - PB no mapa da 75

$\begin{array}{lll}\text { Figura } 29 & \text { Localização da cidade de Pedra Lavrada - PB no } & 77\end{array}$ mapa da Paraíba

Figura 30 Gráfico ilustrando o comércio de bens primários 80 de bentonita $(\mathrm{t})$ - 2002-2007

Figura 31 Quadro demostrando os valores do comércio de 80 bens primários de bentonita (t) de exportação e importação entre 2002-2007

Figura 32 (a) Gráfico demonstrando a estabilidade nos preços de bentonitas nos últimos sete anos; (b) Preços de exportação e importação da bentonita (t) $-2002-2007$

Figura 33 Projeções da demanda 2010/2030 nos três 86 cenários 
Figura 34 Bentonitas que incham em água são 92 transformadas em organofílicas por meio de reações de troca catiônica com sais quaternários de amônio

Figura 35 Esquema da introdução do sal orgânico e da 93 substituição dos cátions trocáveis das argilas por estes sais

Figura $36 \quad$ Esquema de uma argila 2:1 expansível pilarizada

Figura 37 Representação esquemática do processo de 94 pilarização

Figura $38 \quad$ Curvas de difração de raios $X$ das bentonitas da mina Lages:(a) Chocolate; (b) Bofe; (c) Chocobofe; (d) Sortida; (e) Verde Lodo

Figura 39 Curvas das análises térmicas das bentonitas da 121 mina Lages: (a) Chocolate; (b) Bofe; (c) Chocobofe; (d) Sortida; (e) Verde Lodo

Figura 40 Micrografias eletrônicas de varredura das 126 bentonitas da mina Lages: (a) Chocolate; (b) Bofe; (c) Chocobofe; (d) Sortida; (e) Verde Lodo, com aumentos de $2000 \mathrm{X}$

Figura 41 Espectroscopia por energia dispersiva das 130 bentonitas da mina Lages: (a) Chocolate; (b) Bofe; (c) Chocobofe; (d) Sortida; (e) Verde Lodo

Figura 42 Curvas de infravermelho das bentonitas da mina 133 Lages: (a) Chocolate; (b) Bofe; (c) Chocobofe; (d) Sortida; (e) Verde Lodo

Figura 43 Comportamento das argilas 145

Figura 44 Visão geral do sistema de separação óleo/água 146

Figura 45 Ilustração detalhada das vinte amostras coletadas para análise

Figura 46 Curvas de raios $X$ da argila Chocolate sem tratamento e Chocolate modificada com sal 
HDTMA-Cl (cloreto de haxadeciltrimetilamônio GENAMIN-CTAC50) com diferentes concentrações

Figura 47 Curvas de raios $X$ da argila Fluid Gel sem 148 tratamento e Fluid Gel modificada com o sal HDTMA-Cl (GENAMIN-CTAC50) com diferentes concentrações

Figura 48 Curvas de análises térmicas, DTA da amostra 149 Chocolate modificada com o sal HDTMA-Cl (GENAMIN-CTAC50) com diferentes concentrações.

Figura 49 Curvas de análises térmicas, DTA da amostra 150 Fluid Gel modificada com o sal HDTMA-Cl (GENAMIN-CTAC50) com diferentes concentrações

Figura 50 Microscopia eletrônica de varredura para a 152 amostra Chocolate sem tratamento, com aumentos de: (a) $\times 50$, (b) $\times 500$ e (c) $\times 1000$

Figura 51 Microscopia eletrônica de varredura para a 153 amostra Chocolate modificada com o sal HDTMA$\mathrm{Cl}$ (80G), com aumentos de: (a) x 50, (b) x $500 \mathrm{e}$ (c) $\times 1000$.

Figura 52 Miscroscopia eletrônica de varredura para a 153 amostra Chocolate modificada com o sal HDTMA$\mathrm{Cl}$ (100G), com aumentos de: (a) x 50, (b) x $500 \mathrm{e}$ $\times 1000$

Figura 53 Microscopia eletrônica de varredurs para a amostra 154 Fluid Gel sem tratamento, com aumentos de: (a) $x$ 50, (b) $\times 500$ e (c) $\times 1000$

Figura 54 Microscopia eletrônica de varredura para a 155 amostra Fluid Gel modificada com o sal HDTMA-Cl (80G), com aumentos de: (a) x 50, (b) x 500 e x 1000 
Figura 55 Microscopia eletrônica de varredura para a amostra Fluid Gel modificada com o sal HDTMA-Cl (100G), com aumentos de: (a) x 50, (b) x 500 e x 1000

Figura 56 Espestroscopia por energia dispersiva das 157 bentonitas Chocolate. (a) sem tratamento, (b) com tratamento com o sal HDTMA-Cl na concentração de $80 \mathrm{G}$ de argila e (c) com tratamento com o sal HDTMA-Cl na concentração de $80 \mathrm{G}$ de argila e (c) com tratamento com o sal HDTMA-Cl na concentração de 100G de argila

Figura 57 Espectroscopia por energia dispersiva das 158 bentonitas Fluid Gel. (a) sem tratamento, (b) com tratamento com o sal HDTMA-Cl na concentração de $80 \mathrm{G}$ de argila e (c) com tratamento com o sal HDTMA-Cl na concentração de $100 \mathrm{G}$ de argila

Figura 58 Capacidade de Adsorção em óleo diesel 159

Figura 59 Capacidade de Adsorção em óleo lubrificante $(\mathrm{g} / \mathrm{g})$ 160 das amostras Sigma com tratamento com o sal HDTMA-Cl (cloreto de hexadeciltrimetilamônio) na concentração de $80 \mathrm{meq} / 100 \mathrm{~g}$, Chocolate sem tratamento e Fluid Gel com tratamento com o sal HDTMA-Cl (cloreto de hexadeciltrimetilamônio) na concentração de 100 meq/100g

Figura 60 llustração das amostras coletadas através do 162 sistema de separação óleo/água (a) amostra coletada antes de passar pela argila organofílica; (b) amostra coletada após ter passado pela argila organofílica

Figura 61 llustração do conjunto de amostras coletadas 163 
através do sistema de separação óleo/água

$\begin{array}{lll}\text { Figura } 62 & \text { Fluxograma demonstrando a seleção inicial das } & 170\end{array}$ argilas

Figura 63 Fluxograma demonstrando a seleção final das 171 argilas

Figura 64 Fluxogramas: (a) Reação de transesterificação; 173 (b)Variação dos parâmetros da reação

Figura 65 Sistema S1 montado para produção do biodiesel 175

Figura 66 Separação de fases do biodiesel 176

Figura $67 \quad$ Sistema S2 177

Figura 68 Separação de fases do biodiesel 178

Figura $69 \quad$ Aquecimento do biodiesel 178

Figura 70 Equipamento para a produção de biodiesel 179 composto de: Reator PARR 4842, manômetro, agitador e sistema de aquecimento

Figura $71 \quad$ Curva de raios X para argila A23 191

Figura $72 \quad$ Curva de raios X para argila A24 192

Figura 73 Espectro de infravermelho da argila A23 195

Figura $74 \quad$ Espectro de infravermelho da argila A24 196 
Figura 75 Micrografia obtida por MEV da argila A 23 com um aumento 1000X (a barra corresponde a 5 micrometros)

Figura 76 Micrografia obtida por MEV da argila A24 com um 197 aumento 1000X (a barra corresponde a 5 micrometros)

Figura $77 \quad$ Espectroscopia de raios $\mathrm{X}$ por energia dispersiva 199 da argila A23

Figura 78 Espectroscopia de raios $\mathrm{X}$ por energia dispersiva 199 da argila A24

Figura 79 Estrutura química do Sal GENAMIN-CTAC50 219

Figura 80 Esquema ilustrativo do processo de preparação 223 das mantas

Figura 81 (a) Manta antes da vulcanização e (b) Manta após 224 vulcanização

Figura $82 \quad$ Corpos de prova 224

Figura 83 Curvas de DRX da argila $\mathrm{CB}$ 227

Figura 84 Curvas de DRX da argila FG 227

Figura 85 Espectroscopia na região do infravermelho das 228 argilas $\mathrm{CB}$ e $\mathrm{FG}$

Figura 86 Micrografia da argila esmectítica $C B$ com um 230 aumento 1000X (a barra corresponde a 50 
micrômetros)

Figura 87 Micrografias da argila esmectítica FG com um 230 aumento 1000X (a barra corresponde a 50 micrometros)

Figura $88 \quad$ Espectroscopia por dispersão de energia da argila 231 bentonítica CB

Figura 89 Espectroscopia por dispersão de energia da argila 232 bentonítica FG

Figura 90 Curvas de raios $\mathrm{X}$ da argila organofílica CBO

Figura $91 \quad$ Curvas de raios $\mathrm{X}$ da argila organofílica FGO 233

Figura 92 Difratograma da argila organofílica comercial 234 importada C30B

Figura 93 Análises conjuntas dos DRX de todas as argilas 235 estudadas

Figura 94 Espectroscopia na região do infravermelho das 236 argilas $\mathrm{CBO}, \mathrm{FGO}$

Figura 95 Micrografia da argila bentonítica CBO com um aumento 1000X (A barra corresponde a 50 micrômetros)

Figura 96 Micrografia da argila bentonítica FGO com um 238 aumento 1000X (A barra corresponde a 50 micrômetros) 
Figura 97 Micrografia da argila organofílica comercial 239 importada C30B com um aumento 1000X (a barra corresponde a $50 \mu \mathrm{m})$

Figura 98 Espectroscopia por dispersão de energia da argila 240 CBO

Figura 99 Espectroscopia por dispersão de energia da argila FGO

Figura 100 Espectroscopia por dispersão de energia da argila C30B

Figura 101 Resistência à tração dos sistemas estudados (a) 244 Resultados das amostras estudadas; (b) Resultados obtidos por Arroyo (2003)

Figura 102 Alongamento na ruptura dos sistemas estudados. 246 (a) Resultados das amostras estudadas; (b) Resultados obtidos por Arroyo, (2003)

Figura 103 Dureza dos sistemas estudados. (a) Resultados 248 das amostras estudadas; (b) Resultados obtidos por Arroyo, (2003)

Figura 104 Densidade dos sistemas estudados. (a) Resultados 250 das amostras estudadas; (b) Resultados obtidos por Arroyo, (2003)

Figura 105 Curvas de raios $X$ dos sistemas estudados 252 (intervalo $2 \Theta$ entre 3 e $30^{\circ}$ )

Figura 106 Curvas de raios $\mathrm{X}$ dos sistemas estudados 
(intervalo do ângulo $2 \Theta$ entre 2 e $10^{\circ}$ )

Figura 107 Esquema llustrativo da metodologia utilizada para 258 o tratamento ácido com $\mathrm{HCl}$

Figura 108 Esquema ilustrativo da metodologia utilizada para 259 a pilarização da bentonita Sortida

Figura 109 Curvas de raios X da argila bentonítica Sortida (a) 262 natural (b) tratada com $\mathrm{HCl}(3,0 \mathrm{M})$

Figura 110 Perfis de ATG/ATD para bentonita Sortida natural, 263 tratada com ácido clorídrico $(0,5 \mathrm{M} ; 1,0 \mathrm{M} ; 1,5 \mathrm{M}$ e $3,0 \mathrm{M})$

Figura 111 Isoterma Adsorção Física de Nitrogênio 


\section{LISTA DE TABELAS}

Tabela

Página

Tabela 1 Produção de bentonita no mundo (2004-2008)

Tabela 2 Reservas brasileiras de bentonita e argilas descorantes65 2005

Tabela 3 Principais Empresas Produtoras/ Fornecedoras Nacionais

Tabela 4 Evolução do Saldo da Balança Comercial bens primários 79 de bentonita - 2001 a 2008 (US\$ milhões)

Tabela 5 Preços de exportação e bens primários de bentonita 79 $2001-2007(U \$ t)$

Tabela 6 Principais estatísticas do consumo aparente da bentonita 82 - Brasil

Tabela 7 Preços nacionais de bentonita

Tabela 8 Preços internacionais de bentonita (t) 83

Tabela 9 Projeção do consumo de bentonita (t)

Tabela 10 Projeção da produção brasileira - 2010 a 2030

Tabela 11 Principais Aplicações Industriais da Bentonita

Tabela 12 Argilas fornecidas pela empresa BENTONISA 


\section{Bentonitas da Mina Lages}

Tabela 14 Resultados referentes aos argilominerais presentes e a $\mathrm{d}_{001}$

Tabela 15 Resultados referentes as curvas de análises térmicas

Tabela 16 Variação das dimensões dos aglomerados de partículas 128 das argilas

Tabela 17 Valores para as absorções características

Tabela 18 Resultados de FRX para as argilas bentoníticas da mina 138 Lages: (a) Chocolate; Sortida; (e) Verde Lodo

Tabela 19 Resultados de BET para as argilas bentoníticas da mina 140 Lages

Tabela 20 Variação das dimensões dos aglomerados de partículas 156 das argilas hidrofílicas e organofílicas estudadas

Tabela 21 Resultados da separação óleo/água

Tabela 22 Composições empregadas no desenvolvimento desta 172 pesquisa

Tabela 23 Novas composições obtidas com óleo de soja e sistema 174 S3

Tabela 24 Resultados das análises de teor de umidade e pH

Tabela 25 Resultados para as composições F1-F15, ilustrando o 184 aspecto visual da cor do óleo obtido através da utilização 
do sistema S1 e S2

Tabela 26 Referente às viscosidades dinâmicas das amostras no 189 sistema S1 e S2

Tabela 27 Composição química das argilas A 23 e A24

Tabela 28 Características texturais dos catalisadores argilosos

Tabela 29 Composição de ácidos graxos do óleo de soja utilizado

Tabela 30 Características físico-químicas do óleo de soja

Tabela 31 Composição de ácidos graxos do biodiesel de óleo de 203 soja via rota etílica e metílica

Tabela 32 Caracterização físico-química do biodiesel etílico e 207 metílico

Tabela 33 Formulações estudadas

Tabela 34 Composição química das amostras de argilas estudadas

Tabela 35 Valores para as absorções características

Tabela 36 Diâmetro médio dos aglomerados das argilas CB e FG estudadas contados a partir do programa MOCHA da Jandell (analisador de imagens)

Tabela 37 Variação das distâncias basais $\left(\mathrm{d}_{001}\right)$ das argilas 235 estudadas

Tabela 38 Variação das dimensões dos aglomerados das argilas 
naturais e organofílicas contados a partir do programa MOCHA da Jandell (analisador de imagens)

Tabela 39 Propriedades mecânicas dos sistemas: borracha pura, 242 argila organofílica/borracha e negro de fumo/borracha

Tabela 40 Propriedades mecânicas dos sistemas: borracha pura, 243 argila organofílica/borracha e negro de fumo/borracha obtidos por Arroyo (2003)

Tabela 41 Resultados das análises químicas. Composição química 260 da argila antes e após o tratamento com solução de ácido clorídrico $(3,0 \mathrm{M})$

Tabela 42 Área específica dos materiais naturais antes e após a 264 pilarização 


\section{LISTA DE SIGLAS, SÍMBOLOS E UNIDADES}

BET - Brunauer Emmet Teller

BENTONISA - Bentonita do Nordeste S.A

BUN- Bentonit União Nordeste

BVQI - Bureau Veritas Quality Internacional

CETEM - Centro de Tecnologia Mineral

CPTECH - Centro de Pesquisas Tecnológicas

CTC - Capacidade de Troca Catiônica

CTCC - Centro de Tecnologia do Couro e do Calçado Albano Franco

CTGÁS - Centro de Tecnologia do Gás

DNPM - Departamento Nacional de Produção Mineral

DRX - Difração de Raios X

DTA - Análise Térmica Diferencial

EDS - Espectroscopia por Energia Dispersiva

EMBRAPA - Empresa Brasileira de Pesquisa Agropecuária

EPUSP - Escola Politécnica da Universidade de São Paulo

EUA - Estados Unidos da América

FRX - Fluorescência de Raios X

HB- Hamilton Beach

ISO - International Organization for Standardization

LACOM - Laboratório de Combustíveis e Materiais

LMPSol- Laboratório de Matérias-primas Particuladas e Sólidos não Metálicos

IPT - Instituto de Pesquisas Tecnológicas

IV - Espectroscopia na região do infravermelho

MEV - Microscopia Eletrônica de Varredura

pH - Potencial Hidrogeniônico

PMT - Departamento de Engenharia Metalúrgica e de Materiais

SENAI- Serviço Nacional de Aprendizagem Industrial

SUDENE - Superintendência de Desenvolvimento do Nordeste

TG - análise termogravimétrica

USGS - Serviço Geológico dos Estados Unidos 
UFCG - Universidade Federal de Campina Grande

UFPB- Universidade Federal da Paraíba

UFRJ - Universidade Federal do Rio de Janeiro

USP- Universidade de São Paulo

$\lambda=$ Comprimento de onda da radiação;

$\theta=$ Ângulo de incidência.

nm - Nanômetro

$\infty-$ Infinito

mA - Miliampere

kV - Kilovolt

Á - Ampêre

d001 - distância basal

$\mu \mathrm{m}$ - Micrometro 


\section{SUMÁRIO}

CAPÍTULO 1 INTRODUÇÃO 32

$1.1 \quad$ Objetivo Geral 33

$1.2 \quad$ Objetivos Específicos 33

$1.3 \quad$ Organização do Trabalho 34

CAPÍTULO 2 REVISÃO DA LITERATURA 36

$\begin{array}{lll}2.1 & \text { Origem das Bentonitas } & 36\end{array}$

2.1.1 Origem das Bentonitas: no Cenário Mundial (EUA) 36

2.1.2 Origem das Bentonitas: no Cenário Brasileiro 37 (Paraíba)

$\begin{array}{lll}2.2 & \text { Definição de Bentonita }\end{array}$

$\begin{array}{lll}2.3 & \text { Classificação das Bentonitas } & 41\end{array}$

$2.4 \quad$ Aspectos Gerais sobre Bentonitas 42

2.4.1 No Cenário Mundial (EUA) 42

2.4.1.1 Características Geológicas das Bentonitas 43

2.4.1.2 Lavra das Bentonitas 43

2.4.1.3 Processamento/Beneficiamento das Bentonitas 44

2.4.1.4 Reservas das Bentonitas 45

2.4.2 No Cenário Brasileiro (Paraíba) 46

2.4.2.1 Características Geológicas das Bentonitas 46

2.4.2.2 Lavra das Bentonitas 53

2.4.2.3 Processamento / Beneficiamento / Ativação / 54

$\begin{array}{lll}\text { 2.4.2.4 } & \text { Reservas das Bentonitas } & 64\end{array}$

2.4.3 Os Principais Depósitos de Bentonitas da Paraíba 66

$\begin{array}{lll}\text { 2.4.3.1 } & \text { Bentonitas de Boa Vista (PB) }\end{array}$ 
$\begin{array}{lll}\text { 2.4.3.2 } & \text { Bentonitas de Cubati (PB) }\end{array}$

2.4.3.3 Bentonitas de Pedra Lavrada (PB) 76

$\begin{array}{lll}\text { 2.4.4 Os Principais Produtores Nacionais } & 77\end{array}$

2.4.5 Comércio e Preço da Bentonita 78

2.4.6 Bentonitas, Perspectivas no Mercado 84

2.4.7 Principais Usos das Bentonitas 86

2.4.8 Propriedades das Argilas para Aplicação Industrial $\quad 89$

2.4.9 Processo de Modificação de Argilas 91

$\begin{array}{lll}\text { 2.4.9.1 } & \text { Organofilização } & 91\end{array}$

$\begin{array}{lll}\text { 2.4.9.2 } & \text { Pilarização } & 93\end{array}$

$\begin{array}{lll}\text { 2.4.9.3 } & \text { Ativação Ácida }\end{array}$

$\begin{array}{lll}\text { 2.4.9.4 Suporte Catalítico } & 96\end{array}$

2.4.10 Alguns Estudos Realizados no País Utilizando 97 Bentonitas

2.5 Caracterizações Físico-Químicas e Mineralógicas das 98 Bentonitas

2.5.1 $\quad$ Fluorescência de raios X (FRX) 98

2.5.2 Difração de raios X (DRX) 99

2.5.3 Espectroscopia na Região do Infravermelho (IV) 100

2.5.4 Microscopia Eletrônica de Varredura (MEV) / 101

Eletroscopia por Energia Dispersiva (EDS)

$\begin{array}{lll}\text { 2.5.5 } & \text { Análise Textural (BET) } & 101\end{array}$

$\begin{array}{lll}\text { 2.5.6 } & \text { Análises Térmicas } & 101\end{array}$

CAPÍTULO 3 MATERIAIS E MÉTODOS 104

$\begin{array}{lll}3.1 & \text { Materiais Argilosos } & 104\end{array}$

$\begin{array}{lll}3.2 & \text { Metodologia } & 104\end{array}$ 
Espectroscopia por Energia Dispersiva (EDS)

3.2.1.11 Espectroscopia na Região do Infravermelho (IV) das Bentonitas

\section{CAPÍTULO 4 DISCUSSÃO E ANÁLISES DOS RESULTADOS}


4.1.1.3 Microscopia Eletrônica de Varredura (MEV) 126

$\begin{array}{lll}\text { 4.1.1.4 } & \text { Espectroscopia por Energia Dispersiva (EDS) }\end{array}$

4.1.1.5 Espectroscopia na Região do Infravermelho (IV) $\quad 133$

$\begin{array}{lll}\text { 4.1.1.6 } & \text { Fluorescência de raios X (FRX) }\end{array}$

4.1.1.7 Análise Textural - Método BET 140

CAPÍTULO 5 APLICAÇÕES E USOS DA BENTONITA 142

5.1 Aplicação 1: Bentonitas para Tratamento de 142

$\begin{array}{lll}\text { 5.1.1 } & \text { Objetivo desse Estudo } & 144\end{array}$

$\begin{array}{lll}\text { 5.1.2 } & \text { Materiais Utilizados } & 144\end{array}$

$\begin{array}{lll}\text { 5.1.3 } & 145\end{array}$

$\begin{array}{lll}\mathbf{5 . 1 . 4} & \text { Resultados Obtidos } & 147\end{array}$

$\begin{array}{lll}\text { 5.1.4.1 } & \text { Difração de raios X } & 147\end{array}$

5.1.4.2 Análise Termogravimétrica (TG) e Análise Térmica 149

Diferencial (DTA)

5.1.4.3 Microscopia Eletrônica de Varredura (MEV) 151

5.1.4.4 Espectroscopia por Energia Dispersiva (EDS) $\quad 157$

5.1.4.5 Capacidade de Adsorção em Solventes Orgânicos $\quad 159$

$\begin{array}{lll}\text { 5.1.4.6 } & \text { Análise do Teor de óleo/água } & 161\end{array}$

$\begin{array}{lll}\text { 5.1.5 } & \text { Conclusão desse Estudo } & 163\end{array}$

5.2 Aplicação 2: Bentonitas como Catalisadores para 166

Produção do Biodiesel

$\begin{array}{lll}\text { 5.2.1 Objetivo desse Estudo } & 168\end{array}$

$\begin{array}{lll}\text { 5.2.2 } & 168\end{array}$

$\begin{array}{lll}\text { 5.2.3 } & 169\end{array}$

5.2.3.1 $\quad$ Etapa 1 - Seleção das Matérias Primas 169 
Selecionadas

5.2.3.5 Etapa 5 - Caracterização de Óleo de Soja e do

Biodiesel melhores Composições

5.2.4.2.1 Cor do óleo

Parte 3: Caracterização dos Catalisadores

Selecionados

5.2.4.3.1

Difração de raios $X$

Biodieseis Produzidos Através do Sistema S3

5.2.4.4.1.1 Composição Química do Óleo de Soja

5.2.4.4.1.2 Características Físico-químicas do Óleo de Soja 
$\begin{array}{lll}\text { 5.3.1 } & \text { Objetivo desse Estudo }\end{array}$

$\begin{array}{lll}\text { 5.3.2 } & \text { Materiais Utilizados } & 217\end{array}$

$\begin{array}{lll}\text { 5.3.3 } & \text { Metodologia Utilizada } & 218\end{array}$

$\begin{array}{lll}\text { 5.3.4 } & \text { Resultados Obtidos } & 225\end{array}$

5.3.4.1 $\quad$ Fluorescência de raios X (FRX) 225

5.3.4.2 Difração de raios X (DRX) 226

5.3.4.3 $\quad$ Espectroscopia na Região do Infravermelho (IV) 228

5.3.4.4 Microscopia Eletrônica de Varredura (MEV) 229

5.3.4.5 Espectroscopia por Dispersão de Energia (EDS) 231

5.3.4.6 Caracterização das Argilas Organofílicas 232

5.3.4.6.1 Difração de raios X (DRX) 232

5.3.4.6.2 Espectroscopia na Região do Infravermelho (IV) 236

5.3.4.6.3 Microscopia Eletrônica de Varredura (MEV) 237

5.3.4.6.4 Espectroscopia por Dispersão de Energia (EDS) 242

$\begin{array}{lll}\text { 5.3.4.7 } & \text { Propriedades Mecânicas } & 251\end{array}$

5.3.4.8 Difração de raios X (DRX) 251

5.3.5 Conclusões Obtidas 254

5.4 Aplicação 4: Bentonitas modificadas com ácido e com 256 agente pilarizante visando sua utilização como catalisadores

5.4.1 Objetivo desse Estudo 256

$\begin{array}{lll}\text { 5.4.2 } & \text { Materiais Utilizados }\end{array}$

$\begin{array}{lll}\text { 5.4.3 } & \text { Metodologia Utilizada } & 257\end{array}$

5.4.3.1 Parte I - Tratamento Ácido 257

$\begin{array}{lll}\text { 5.4.3.2 } & \text { Parte II - Pilarização } & 258\end{array}$

5.4.3.3 Parte III - Métodos de ensaios de caracterização 260 
5.4.4.1 Parte I - Tratamento Ácido 260

$\begin{array}{lll}\text { 5.4.4.1.1 } & \text { Fluorescência de raios X }\end{array}$

$\begin{array}{lll}\text { 5.4.4.1.2 } & \text { Difração de raios X }\end{array}$

5.4.4.1.3 Análises Térmicas Diferencial e Termogravimétrica 262

$\begin{array}{lll}\text { 5.4.4.2 } & \text { Parte II - Pilarização }\end{array}$

5.4.4.2.1 Caracterização Textural- Método de BET 264

5.4.5 Conclusões Obtidas 265

$\begin{array}{lll}\text { CAPÍTULO } 6 & \text { CONCLUSÕES } & 268\end{array}$

CAPÍTULO 7 SUGESTÕES PARA TRABALHOS FUTUROS 272

CAPÍTULO 8 REFERÊNCIAS DA LITERATURA 274 
CAPÍTULO 1 INTRODUÇÃO 


\section{CAPITULO 1- INTRODUCÃO}

\subsection{INTRODUÇÃO}

O Brasil é um importante produtor de materiais cerâmicos possuindo um considerável número de jazidas de argilas. A existência de dados técnico-científicos orientam a utilização e aplicação industrial das argilas, bem como, sua utilização de maneira racional e otimizada por parte do setor industrial (MENEZES et. al., 2009).

$\mathrm{Na}$ Paraíba e regiões circunvizinhas é observada uma acentuada atividade industrial na extração e beneficiamento de argilas, destacando-se o município de Boa Vista-PB que apresenta as principais jazidas de bentonitas do país, que atualmente são utilizadas comercialmente em uma vasta gama de setores tecnológicos.

Souza Santos (1992) define argilas como sendo rochas sedimentares formadas pela alteração dos silicatos de alumínio de origem magmática, metamórfica ou sedimentar, sendo rochas naturais com granulações finas, terrosas e que geralmente quando umedecidas com água adquirem certa plasticidade. As argilas são essencialmente formadas por silicatos hidratados de alumínio, ferro e magnésio, mas podendo também conter minerais acessórios (quartzo, cristobalita, micas, feldspatos e outros), além de matéria orgânica e outras impurezas. As bentonitas, caulins, ball-clays, argilas refratárias, flints-clays e terras fuller são tipos de argilas industriais. Para Souza Santos, as bentonitas são argilas esmectíticas que nelas possam ser desenvolvidas propriedades que as permitam ter usos tecnológicos análogos às bentonitas tradicionais estrangeiras (caso da bentonita de Wyoming, EUA).

As primeiras reservas de bentonitas na Paraíba foram encontradas em 1961, no município de Boa Vista. As bentonitas de Boa Vista-PB são de origem continental, vulcano-sedimentar (derrames de lavas basálticas), que preencheram lagos e canais. Possuem grandes variedades de empregos industriais por causa das suas interessantes propriedades físico-químicas e devido ao alto teor de argilas esmectíticas em sua composição. Esse fato torna a Paraíba um Estado privilegiado, 
pois tem sido o principal Estado produtor desse bem mineral tanto bruto quanto beneficiado.

Pesquisadores da região têm dedicado grandes esforços na caracterização, bem como, na avaliação da possibilidade de novos usos destas bentonitas nos mais diversos setores industriais, como por exemplo: nanotecnologia, meio ambiente, cosméticos, saúde, dentre outros.

Levando-se em consideração que o Estado da Paraíba possui importantes depósitos de bentonitas, torna-se importante a realização de um estudo tecnológico detalhado e atualizado através de caracterização físico-química e mineralógica que possa contribuir ao conhecimento destas argilas presentes na região da Paraíba. Nesse contexto, este trabalho visa complementar e atualizar estudos tecnológicos das bentonitas da mina Lages, localizada em Boa Vista-Paraíba realizados pelo professor Dr. Pérsio de Souza Santos em 1976. Também, serão expostos os resultados para os diversos usos dessas argilas estudados pela autora nos últimos 10 anos.

\subsection{Objetivo Geral}

O objetivo geral deste trabalho é contribuir com os estudos realizados sobre as bentonitas do Estado da Paraíba por meio das caracterizações físico-químicas e mineralógicas de alguns ensaios tecnológicos para algumas argilas presentes atualmente na região de Boa Vista, mina Lages.

\subsubsection{Objetivos Específicos}

Como objetivos específicos têm-se:

- Selecionar amostras de bentonitas da Paraíba a serem estudadas nessa pesquisa.

- Submeter as diversas amostras de bentonitas a ensaios de caracterizações físico-químicos e mineralógicos.

- Apresentar algumas das possíveis aplicações industriais para estas argilas. 


\subsection{Organização do Trabalho}

O presente trabalho está organizado em 7 capítulos.

No Capítulo 1 é apresentada a introdução, descrevendo a justificativa para a realização desta pesquisa, bem como, os seus objetivos gerais e específicos, além da organização do trabalho, onde descreve-se o conteúdo dos seus diversos capítulos.

No Capítulo 2 encontra-se a revisão da literatura sobre os temas relevantes para a realização desse estudo.

No Capítulo 3 estão descritos os materiais e a metodologia utilizada para o desenvolvimento desta pesquisa.

No Capítulo 4 são apresentados e discutidos os resultados para os materiais argilosos utilizados nessa tese.

No Capítulo 5 são apresentados os resultados para os usos dos materiais argilosos estudados.

Logo em seguida, nos Capítulos 6 e 7 encontram-se apresentadas as conclusões do estudo, seguidos das sugestões para trabalhos futuros e das referências bibliográficas. 
CAPÍTULO 2 REVISÃO DA LITERATURA 


\section{CAPÍTULO 2- REVISÃO DE LITERATURA}

Neste capítulo serão apresentados e detalhados assuntos referentes ao tema abordado nesse estudo.

\subsection{BENTONITA}

\subsection{Origem das bentonitas}

\subsubsection{Origem das Bentonitas: no Cenário Mundial (EUA)}

O termo bentonita foi derivado da localização do primeiro depósito comercial de uma argila encontrada nos Estados Unidos (EUA) (FERREIRA; SILVA, 2008) .

Knight reportou que desde 1888 William Taylor comercializava uma argila peculiar encontrada em Fort Benton (Wyoming, EUA) e propôs a denominação "taylorite", sugerindo em seguida "bentonita", uma vez que a primeira denominação já era utilizada (GRAY,1988 apud FERREIRA; SILVA, 2008) .

Logo, o termo "bentonita" foi citado pela primeira vez na literatura pelo geólogo Knight em 1897, referindo-se a uma argila de consistência plástica e coloidal localizada (figura 1) em uma jazida nas proximidades de Fort Benton (Wyoming, EUA) (NEUMANN et. al., 2000).

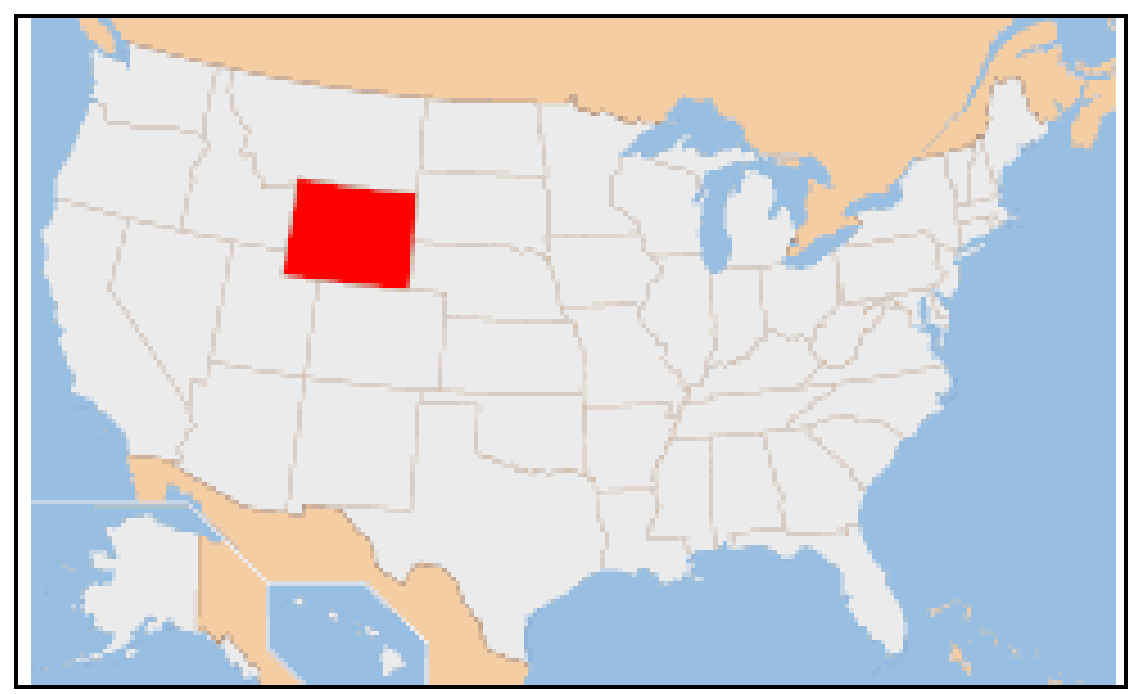

Figura 1: Mapa de localização de Wyoming (EUA).

Fonte: Gopinath, (2004). 
A figura 2 ilustra 0 depósito descoberto em folhelhos argilosos no Fort Benton, Wyoming (EUA), onde a bentonita foi pela primeira vez caracterizada como um tipo especial de argila industrial (NEUMANN et. al., 2000).

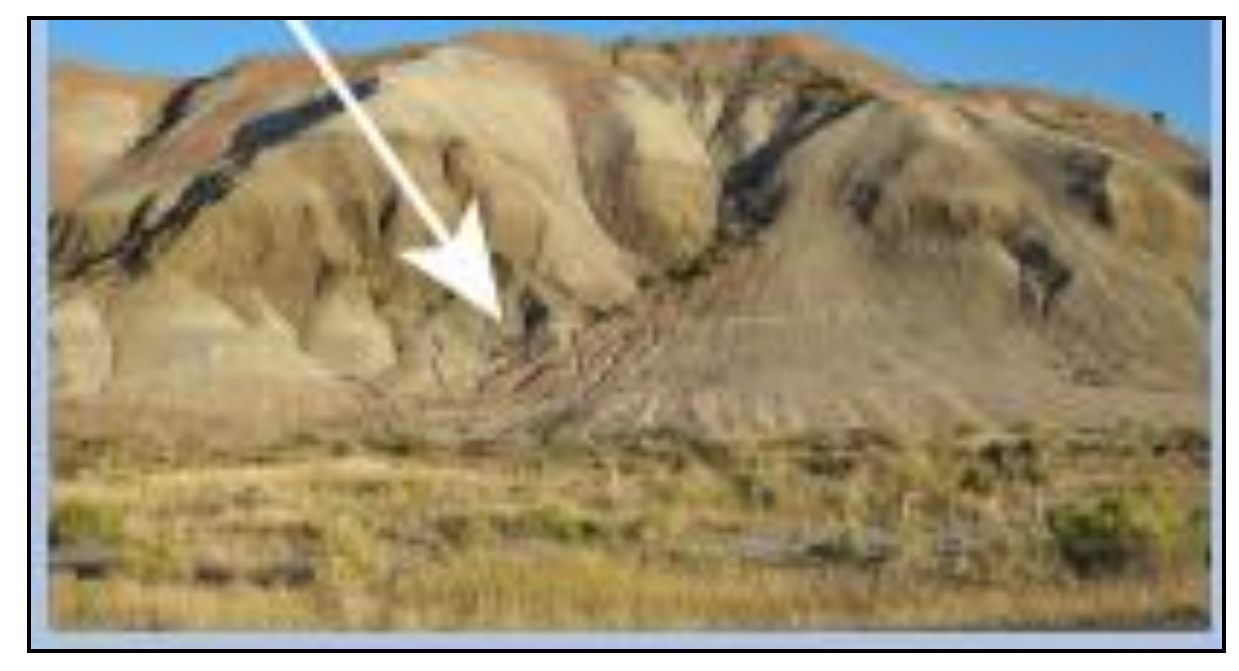

Figura 2: Foto ilustrando os folhelhos argilosos do Fort Benton, Wyoming (EUA). Fonte: $<$ www.rawell.co.uk/products technical information/what is bentonite.php $>$, (2011).

Pequenas quantidades de bentonita de Wyoming (EUA) foram primeiramente exploradas comercialmente e desenvolvidas na área de River Rock durante a década de 1880. Em 1920, os depósitos mais importantes foram descobertos em outras partes do Estado de Wyoming e a primeira planta de processamento, foi construída durante esse período (BENTONIT, 2005). Atualmente, o mercado de bentonita está muito concentrado nos EUA, sendo considerado o maior produtor mundial e que conta com elevados investimentos aplicados nessa indústria, os quais vêm proporcionando diversificação no seu uso e aplicação (DNPM,2009).

\subsubsection{Origem das Bentonitas: no Cenário Brasileiro (Paraíba)}

Os habitantes de Boa Vista-Paraíba, na época distrito do município de Campina Grande (figura 3), conheciam um material que possuía cores diversas e propriedades consideradas interessantes. Os mesmos relatavam que quando molhavam esse material, ele apresentava-se escorregadio e assemelhava-se a um pedaço de sabão, podendo ser utilizado como giz. Mais tarde, na década de 60, 
após investigações científicas promovidas pelo DNPM (Departamento Nacional de Produção Mineral), ficou constatado que aqueles materiais tratavam-se de bentonitas (BENTONIT, 2005).

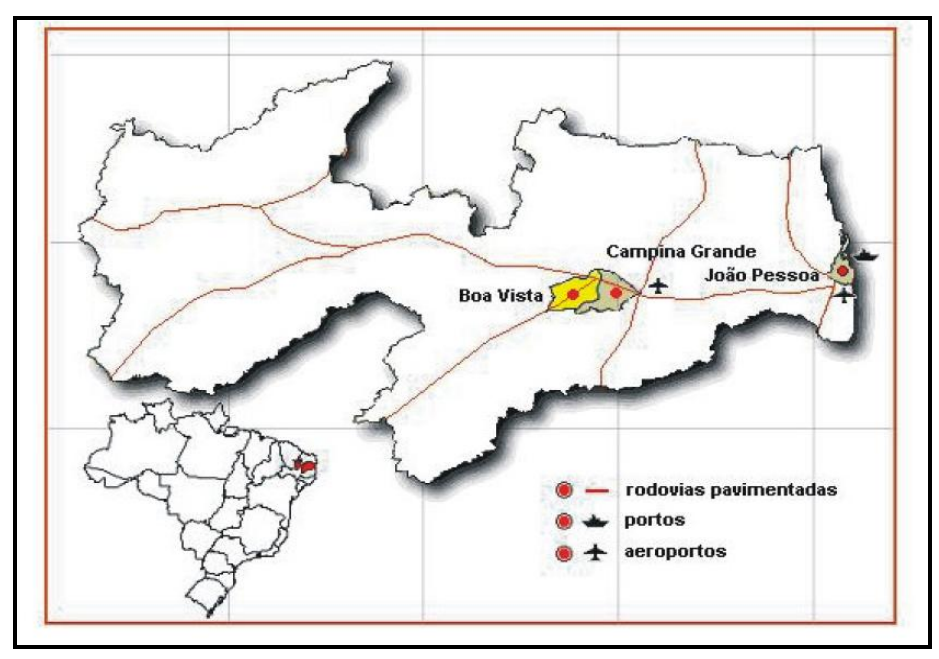

Figura 3: Mapa de localização de Boa Vista- PB.

Fonte: Gopinath, (2004).

As primeiras amostras de bentonitas descobertas no município de Boa VistaPB foram levadas para serem estudadas na Escola Politécnica da Universidade de São Paulo (EPUSP) em 1961, através de ensaios cerâmicos realizados pelo Eng ${ }^{\circ}$ Químico Marcello Renato Arruda. Nessa época, aluno no Departamento de Engenharia Química da EPUSP e aluno-assistente da Seção de Cerâmica do Instituto de Pesquisas Tecnológicas (IPT). Essas argilas foram ensaiadas para fins cerâmicos e também foi realizada uma identificação mineralógica qualitativa por análise térmica diferencial e por difração de raios X (SOUZA SANTOS, 1976). A presença de argilominerais esmectíticos foi detectada nas amostras e comunicada aos proprietários de jazidas da região, para que os mesmos soubessem que 0 material encontrado tratava-se de um tipo de argila especial, denominado bentonita (figura 4), que a mesma possuía diversos usos industriais, tendo sido sugerida a industrialização imediata dessas argilas.

Posteriormente, outras amostras foram trazidas por comerciantes de minérios do Nordeste e as primeiras bentonitas começaram a ser extraídas das localidades de Lages e Bravo, de propriedade dos senhores João Paulo de Almeida e Antônio de Almeida. Inicialmente a industrialização foi realizada pelas Indústrias Mendes, de Sorocaba, Estado de São Paulo, que já industrializavam a bentonita de Ponte Alta e 
a nontronita de Sacramento, Minas Gerais e posteriormente pela Bentonit União, também do Estado de São Paulo. Anos após, esta empresa transferiu-se para Campina Grande, Paraíba. As argilas também foram industrializadas pela empresa "PROQUIMA" (localizada em Recife-PE) e também pela empresa "Argilas e Minérios Nordestinos S.A.- ARNOSA" (localizada em Campina Grande-PB).

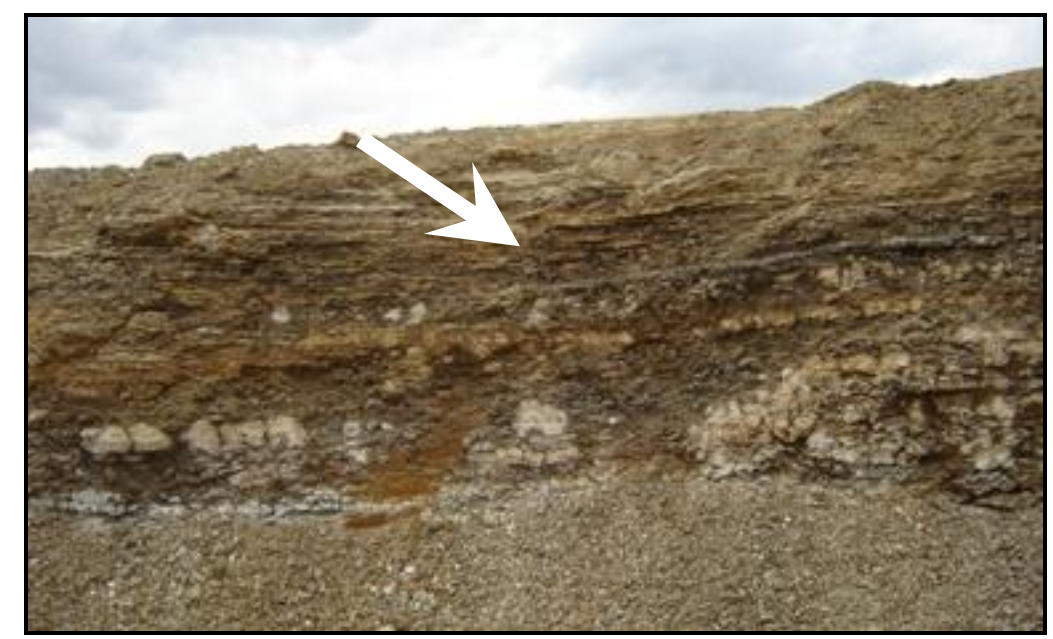

Figura 4: Foto ilustrando os folhelhos argilosos de Boa Vista (PB).

Fonte: Adriana Silva, (2011).

A primeira aplicação industrial que gerou comercialização da bentonita da Paraíba foi como diluente para inseticidas, para este fim utilizou-se a camada de argila superior de coloração amarela do depósito de Boa Vista, localmente designada por "Bofe".

$\mathrm{Na}$ mesma época a SUDENE (Superintendência de Desenvolvimento do Nordeste) também fez um estudo geológico do depósito das bentonitas de Boa Vista-PB, apontando a natureza sedimentar do mesmo, indicando a localização dos diversos afloramentos e apresentando um mapa geológico da região. $\mathrm{O}$ Departamento Nacional de Produção Mineral - DNPM, por iniciativa de Fleury da Rocha fez um levantamento preliminar do depósito da localidade de Bravo, por meio de sondagens. A reserva medida e inferida, cobria uma área sedimentar de 214.000 $\mathrm{m}^{2}$, com espessura média de $14 \mathrm{~m}$, levando a um volume de $2.989,580 \mathrm{~m}^{3}$ ou cerca de 6 milhões de toneladas de bentonita (adaptado de SOUZA SANTOS, 1976).

Segundo Bertolino (2010), recentemente foram descobertos novos depósitos de bentonitas na região de Cubati e Pedra Lavrada-PB, criando uma grande expectativa de ampliação da produção mineral na região. Estudos para o 
desenvolvimento de aplicações industriais estão sendo realizados e precisam ser aprofundados. Dentre em breve, espera-se que através dos resultados de caracterização física e mineralógica desses materiais, seja possível beneficiar e comercializar as bentonitas desses novos depósitos.

\subsection{Definição de Bentonita}

Geologicamente, bentonita foi definida por Ross e Sahronnon (1926) como sendo uma rocha constituída essencialmente por um argilomineral montmorilonítico, formada pela desvitrificação e subsequente alteração química de um material vítreo, de origem ígnea, usualmente um tufo ou cinza vulcânica, ácida de preferência (MENEZES et. al., 2009).

Tecnologicamente as argilas esmectíticas são denominadas bentonitas, pois há um consenso entre os pesquisadores da área cerâmica que se as argilas esmectíticas apresentarem propriedades análogas às das bentonitas tradicionais e/ou se já forem utilizadas comercialmente para essa finalidade, podem ser denominadas bentonitas, independentemente de sua origem geológica. Logo, geralmente o termo "esmectitas" é utilizado como sinônimo de bentonitas ou de argilas esmectíticas (MENEZES et. al., 2009).

Segundo o Departamento Nacional de Produção Mineral - DNPM, bentonita é - nome genérico da argila composta predominantemente por argilominerais esmectíticos com o teor variando entre $55 \%$ e $70 \%$, independentemente de sua origem ou ocorrência. Para o DNPM, também são consideradas bentonitas as argilas que possuem como características principais: o alto poder de inchamento, ou seja, podem apresentar até 20 vezes seu volume inicial; capacidade de atingir espaços interplanares de até $100 \AA$; alta área de superfície (até $800 \mathrm{~m} / \mathrm{g}$ ); capacidade de troca catiônica (CTC) na faixa de 60 a 170 meq/100 g e tixotropia. Estas características conferem à bentonita propriedades bastante específicas, que justificam uma vasta gama de aplicações nos mais diversos segmentos industriais (DNPM, 2004).

Segundo Abreu (1973), as bentonitas possuem alta capacidade de adsorção e alto teor de matéria coloidal, ou ainda, grande possibilidade de ativação. Têm composição química muito variável e suas aplicações são numerosas. Todos os 
tipos de bentonita têm alguns ou vários argilominerais do grupo das esmectitas, geralmente apresentando a montmorilonita como argilomineral predominante.

Segundo a publicação do CETEM (Centro de Tecnologia Mineral) intitulada Rochas e Minerais Industriais, as bentonitas são constituídas principalmente pelo argilomineral montmorilonita, este faz parte do grupo das esmectitas. São também denominados de bentonita materiais com alto teor de esmectita (LUZ, 2008).

Para o grupo de pesquisadores liderado pelo Prof. Dr. Valenzuela-Diaz (2011), a bentonita é uma rocha constituída essencialmente por argilominerais do grupo das esmectitas, sendo eles: montmorilonita propriamente dita, nontronita, beidelita, hectorita, saponita e sauconita. Esses argilominerais caracterizam-se por apresentarem na sua estrutura cristalina o alumínio ou magnésio substituídos parcial ou totalmente por $\mathrm{Mg}^{2+}, \mathrm{Fe}^{3+}$ e outros cátions. Do ponto de vista estrutural, os argilominerais da bentonita são constituídos por diversas unidades empilhadas que compreendem camadas, que contém íons coordenados octaedralmente entre duas camadas de íons coordenados tetraedralmente. Além disso, as bentonitas são argilas que apresentam como principais propriedades: um alto poder de inchamento, alta área de superfície, grande capacidade de troca catiônica e possibilidade de formar géis (tixotropia), apresentando portanto, um amplo uso industrial.

\subsection{Classificação das Bentonitas}

Para uso industrial, as bentonitas podem ser classificadas como: bentonitas que têm o sódio como principal cátion interlamelar e possuem propriedade de inchar em água e bentonitas que apresentam cálcio como cátion predominante e não incham em presença de água (PEREIRA, 2003).

"As bentonitas que incham em água", figura 5 (a), são aquelas caracterizadas por uma propriedade específica de inchar até vinte vezes o volume de argila seca, quando imersas em água. Em outras palavras, as bentonitas sódicas que incham em água são altamente hidrofílicas, adsorvendo água na forma de esferas de hidratação dos cátions $\mathrm{Na}^{+}$intercalados (PEREIRA, 2003).

O comportamento de expansão das bentonitas sódicas, também chamado de inchamento foi amplamente discutido por vários autores como Souza Santos, Luckham e Rossi; Volzone et.al.; Pereira et. al.; Nunes e Airoldi; Silva; ValenzuelaDiaz. Esta expansão deve-se ao equilíbrio de ionização entre os cátions adsorvidos 
e a superfície das partículas, que ocorre quando a argila é dispersa em água, processo pelo qual a distância interplanar basal $\left(\mathrm{d}_{001}\right)$ se expande além do seu limite original (em torno de 9,5 Á), como resultados da adsorção de moléculas de água nos espaços interlamelares, podendo atingir até $40 \AA ̂$ (JOSÉ, 2003).

"Bentonitas que não incham em água", figura 5 (b), podem ter a composição mineralógica idêntica a das bentonitas que incham, diferem-se das bentonitas que incham, nos cátions trocáveis, predominantemente $\mathrm{Ca}$ e $\mathrm{Mg}$, e ainda por não evidenciar tixotropia. Entende-se por tixotropia como sendo um fenômeno pelo qual certas substâncias passam do estado de Gel para o estado líquido, após ligeira agitação.

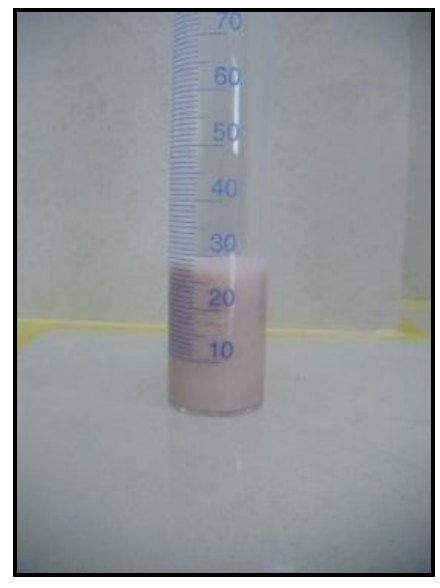

(a)

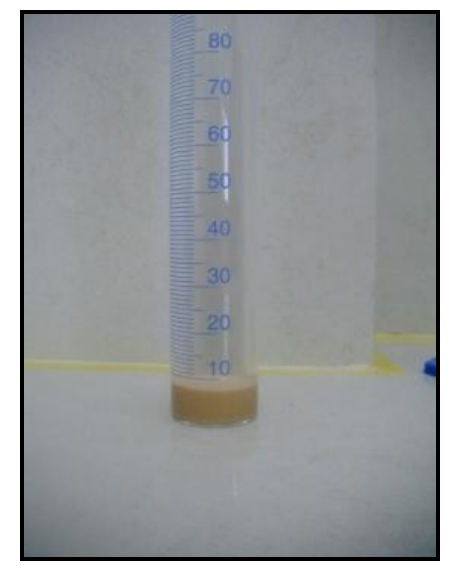

(b)

Figura 5: Foto ilustrando o inchamento das: (a) Bentonitas que incham em água; (b) Bentonitas que não incham em água. Foi utilizado $1 \mathrm{~g}$ de argila para $100 \mathrm{~mL}$ de $\mathrm{H}_{2} \mathrm{O}$.

Fonte: Adriana Silva, (2011).

\subsection{ASPECTOS GERAIS SOBRE AS BENTONITAS}

\subsubsection{No Cenário Mundial (EUA)}




\subsubsection{Características Geológicas das Bentonitas}

A bentonita, na região de Wyoming, ocorre em rochas do cretáceo e terciário. E é uma rocha composta essencialmente de uma argila cristalina, tendo as características de um mineral formado pela desvitrificação de um material ígneo e vítreo, normalmente um tufo ou cinza vulcânica. Esse material normalmente contém proporções variadas de grãos de cristais acessórios que foram originalmente fenocristais num vidro vulcânico. Esses minerais geralmente são feldspatos (orclásio e oligoclásio), biotita, quartzo, piroxênio, zircônio e vários outros tipos de minerais, característicos de rochas vulcânicas (ELZEA E MURRAY, 1995; LUZ et al.,2001 APUD LUZ et al.,2008).

No município de Greybull, ao norte do Estado de Wyoming - EUA, quase na fronteira com o Estado de Montana encontra-se em lavra uma mina de bentonita pertencente à empresa WYO-BEM, INC. As bentonitas de Wyoming são sódicas, de alta capacidade de inchamento e, portanto, os tipos eficientes para lama de perfuração. As propriedades de alta viscosidade da hectorita fazem desta, uma argila bastante adequada para lama (LUZ, 2008).

\subsubsection{Lavra das Bentonitas}

Conhecida como bentonita de Wyoming, a mesma é lavrada nos três principais distritos que atravessam os estados de: Wyoming (figura 6), Montana e South Dakota. As cinco usinas que produzem bentonita sódica na região constituem o distrito mineiro de bentonita sódica mais antigo do mundo (ELZEA E MURRAY, 1995; LUZ et al.,2001 apud LUZ et al.,2008).

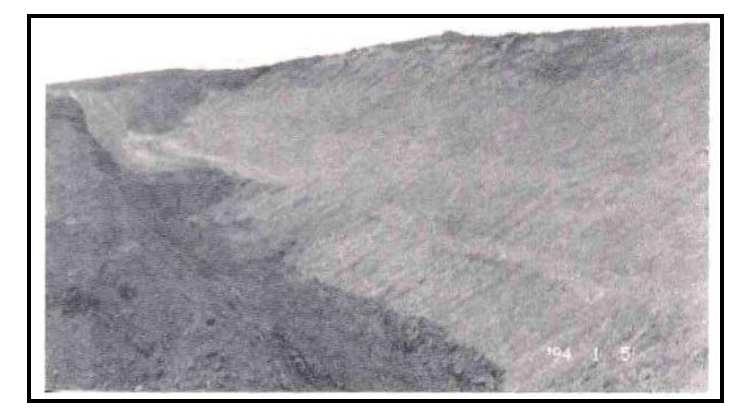

Figura 6: Foto da frente de lavra da bentonita de Wyoming.

Fonte: LUZ, (2008). 
A lavra da bentonita na região é feita a céu aberto, normalmente, usando o método de lavra por tira (strip mining), como ilustrado na figura 6. A espessura da camada de bentonita varia de 2 a $3 \mathrm{~m}$ e o comprimento entre 2 a $5 \mathrm{Km}$ (LUZ et. al.,2008).

Na lavra são empregados trator e motorscreiper para fazer o decapeamento. O carregamento da bentonita é feito em caminhões fora de estrada. Em uma frente de lavra típica, podem ser identificados sete tipos de bentonita (verde, amarela, etc.). A lavra de cada tipo depende muito do uso que se requer do produto a ser obtido (lama de perfuração, areia de fundição, pelotização de minérios de ferro, etc.).

$\mathrm{Na}$ estação chuvosa é praticamente impossível trabalhar na frente de lavra, devido ao estado escorregadio da superfície do solo. Para superar esse problema operacional, lavra-se determinado volume de bentonita, nos períodos secos, e estoca-se no pátio da usina, para processamento em estação chuvosa (LUZ, 2008).

\subsubsection{Processamento / Beneficiamento das Bentonitas}

O processamento da bentonita, na região ao norte de Wyoming, consiste de britagem, secagem, moagem e ensacamento.

Os diferentes tipos de bentonitas provenientes da frente de lavra são estocados em pilhas no pátio da usina. Dependendo do produto que se deseja obter, é feita blendagem no próprio pátio e a seguir a bentonita é submetida a britagem e secagem em forno rotativo, onde a umidade é reduzida de 30 para $10 \%$. O produto da secagem é submetido à moagem em moinho Raymond, em circuito fechado com classificador pneumático, obtendo-se um produto com granulometria abaixo de 200 mesh, a seguir acondicionando em sacos de 50 ou $100 \mathrm{lb}$ (23 ou $45 \mathrm{~kg}$ ).

Normalmente, os produtos obtidos no processamento da bentonita são submetidos a ensaios de controle de qualidade, em laboratório contíguo à própria indústria. No caso de produtos direcionados para lama de perfuração, os ensaios são executados segundo as normas API e os mais comuns são: viscosidade plástica usando viscosímetro Fann; determinação de filtrado API; resíduo em 200 mesh; ensaios de inchamento; ensaios de rendimento. No caso da caracterização de produtos para outras finalidades, são executados ensaios de absorção d'água; de absorção de óleo, etc. (LUZ, 2008). 


\subsubsection{Reservas das Bentonitas}

A expressiva abundância das reservas mundiais de bentonita dificulta a efetivação da estimativa desses recursos em um contexto global, porém, segundo dados do DNPM (2007) em nível mundial a produção de bentonita em 2007 obteve um acréscimo de 0,4\% em relação a 2006.

As maiores reservas estão nos EUA (sódica advinda dos Estados de Wyoming, Dakota do Sul e Montana, e cálcicas provenientes dos Estados do Mississipi, Texas e Arizona), Grécia, Comunidade dos Estados Independentes (CEI), Alemanha, República Tcheca, Turquia e México (DNPM, 2007).

Com relação às reservas mundiais de bentonita, calculadas pelo USGS (Serviço Geológico dos Estados Unidos) em 2008, atingiram o montante de 1.360 milhões de toneladas e devido à abundância dessas reservas mundiais a sua estimativa não vem sendo publicada. Os EUA possuem mais de $50 \%$ deste total e é o principal produtor mundial de bentonita sódica, alcançando cerca de $32 \%$. Outros países que se destacam na produção de bentonitas são: China, Grécia, Índia, Turquia e Rússia, conforme pode ser observado na tabela 1. O Brasil apresentou uma produção de 400.000 t em 2008, representou cerca de 2,6 \% do total mundial (COELHO, 2010).

Os depósitos de bentonita branca são raros, devido às condições peculiares de formação geológica (ausência de matéria orgânica e de rochas contendo ferro e outros metais com cátions coloridos durante a decomposição de cinzas vulcânicas ricas em sílica). São constituídas essencialmente por montmorilonita-Na sem ferro estrutural e sílica coloidal; hectorita- $\mathrm{Na}$ e saponita-Na podem ser também os constituintes de bentonitas brancas comerciais. Existem depósitos explorados comercialmente apenas na Califórnia e em Nevada (Death Valley e Amargosa Valley) e Texas (Gonzáles), USA; na Turquia (Balikesia) e Grécia (ilha de Kimilos). Os Estados Unidos são os maiores produtores: 225.000 t/ano. As bentonitas brancas lavadas são vendidas por US $\$ 4.000,00 / t$. Das 200.000 t produzidas na Califórnia e Nevada, cerca de 55\% são usadas para gelificação em cosméticos, produtos de toalete e produtos para limpeza doméstica; cerca de $35 \%$ são usados como agentes estabilizantes de suspensões desses mesmos produtos e $8 \%$ são usados como agente plastificante em cerâmica elétrica. A bentonita branca 
produzida no Texas é utilizada industrialmente para: esmaltes e vidrados cerâmicos; agente plastificante para cerâmica branca, cerâmica elétrica, cerâmica técnica e refratários plásticos. Na Província de San Juan, região andina da Argentina, existem vários depósitos de bentonita (VIEIRA COELHO, 2007).

Tabela 1: Produção de bentonita no mundo (2004-2008).

\begin{tabular}{|cccccc|}
\hline PAIS & \multicolumn{2}{r}{$\mathbf{2 0 0 4}$} & $\mathbf{2 0 0 5}$ & $\mathbf{2 0 0 6}$ & $\mathbf{2 0 0 7}$ \\
\hline & & \multicolumn{2}{c}{ Toneladas } \\
\hline EUA & 4.060 .000 & 4.710 .000 & 4.940 .000 & 5.070 .000 & 4.870 .000 \\
\hline CHINA & 2.250 .000 & 2.300 .000 & 3.200 .000 & 3.200 .000 & 3.300 .000 \\
\hline GRÉCIA & 1.030 .556 & 1.124 .795 & 1.100 .000 & 1.100 .000 & 1.525 .000 \\
\hline INDIA & 410.000 & 590.000 & 610.000 & 630.000 & 710.000 \\
\hline TURQUIA & 643.153 & 582.735 & 400.000 & 400.000 & 683.253 \\
\hline RÚSSIA & 500.000 & 500.000 & 456.000 & 460.000 & 460.000 \\
\hline BRASIL & 226.874 & 221.300 & 265.032 & 238.746 & 265.032 \\
\hline OUTROS & 6.224 .067 & 4.132 .791 & 3.674 .786 & 4.510 .353 & 3.651 .747 \\
\hline PROD TOTAL & 13.300 .000 & 14.400 .000 & 14.800 .000 & 15.700 .000 & 15.600 .000 \\
\hline MUNDIAL & & & & & \\
\hline
\end{tabular}

Fonte: BGS, (2010) apud Coelho, (2010),adaptado.

\subsubsection{No Cenário Brasileiro (Paraíba)}

\subsubsection{Características Geológicas das Bentonitas}

Os principais depósitos industriais brasileiros de bentonitas encontram-se na Paraíba especificamente nos municípios de Boa Vista, Cubati e Pedra Lavrada (figura 7). 


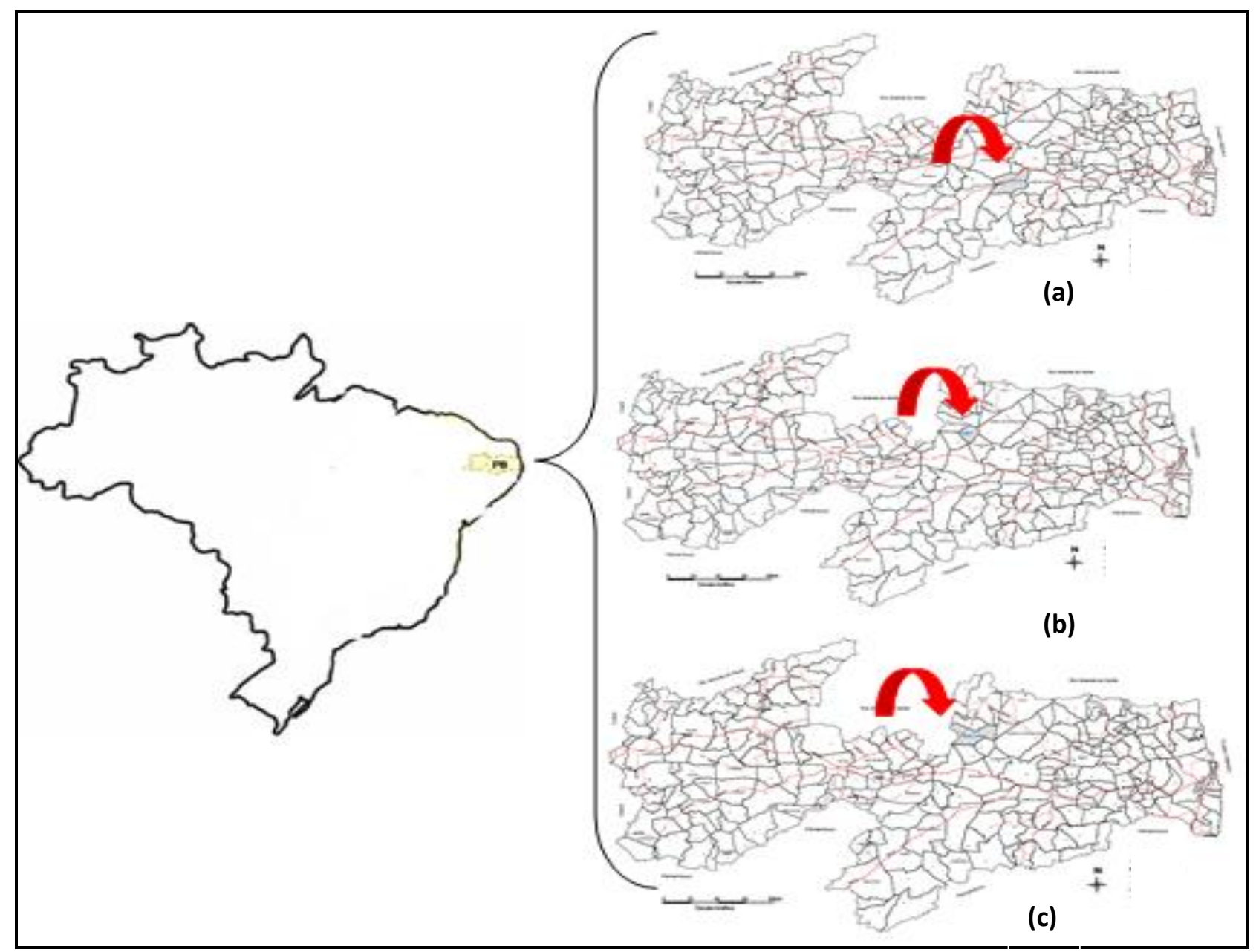

Figura 7: Ilustração no mapa dos municípios de: (a) Boa Vista, (b) Cubati e (c) Pedra Lavrada.

Fonte: CPRM, (2005).

Segundo Gopinath (2003), os depósitos de bentonitas da Paraíba são associadas aos arenitos grosseiros conglomeráticos na base gradando para arenitos finos, siltitos e argilas montmoriloníticas no topo, com intercalações de delgadas camadas na porção medial, e possivelmente no topo. Ainda se encontram intercaladas camadas finas de calcedônia na parte superior da sequência (GOPINATH et. al., 2003).

Gopinath et.al. (2004) relata que, com relação à gênese dos depósitos, foram levantadas diversas hipóteses: sedimentar, por Caldasso (1979); hidrotermal, por Pinto e Pimentel (1968); vulcano-sedimentar, por Ennes e Santos (1975), além do DNPM (1973). 
No que se refere à idade de formação, foram atribuídos aos derrames basálticos que a capeiam a idade de Cretáceo superior - Terciário inferior.

Os estudos detalhados de geologia, mineralogia e química por Gopinath et.al. (1981), mostraram que as bentonitas de Boa Vista (figura 8 (a)) são resultado de alterações dos materiais piroclásticos de natureza tufo e lapilli provenientes do vulcanismo local.

O município de Boa Vista, está inserido na unidade geoambiental do Planalto da Borborema, formada por maciços e outeiros altos, com altitude variando entre 650 a 1.000 metros. Ocupa uma área de arco que se estende do sul de Alagoas até o Rio Grande do Norte. O relevo é geralmente movimentado, com vales profundos e estreitos dissecados. Com respeito à fertilidade dos solos é bastante variada, com certa predominância de média para alta (CPRM, 2005).

A área da unidade é recortada por rios perenes, porém de pequena vazão e o potencial de água subterrânea é baixo (CPRM, 2005). A vegetação desta unidade é formada por Florestas Subcaducifólica e Caducifólica, próprias das áreas agrestes. O clima é do tipo Tropical Chuvoso, com verão seco. A estação chuvosa se inicia em Janeiro/Fevereiro com término em Setembro, podendo se adiantar até Outubro. Nas superfícies suavemente onduladas, a onduladas, ocorrem os Planossolos, medianamente profundos, fortemente drenados, ácidos a moderadamente ácidos e fertilidade natural média e ainda os Podzólicos, que são profundos, textura argilosa, e fertilidade natural média a alta. Nas elevações ocorrem os solos Litólicos, rasos, textura argilosa e fertilidade natural média. Nos Vales dos rios e riachos, ocorrem os Planossolos, medianamente profundos, imperfeitamente drenados, textura média/argilosa, moderadamente ácidos, fertilidade natural alta e problemas de sais. Ocorrem ainda afloramentos de rochas (CPRM, 2005).

O município de Cubati (figura 8 (b)), está inserido na unidade geoambiental do Planalto da Borborema, formada por maciços e outeiros altos, com altitude variando entre 650 a 1.000 metros. Ocupa uma área de arco que se estende do sul de Alagoas até o Rio Grande do Norte. O relevo é geralmente movimentado, com vales profundos e estreitos dissecados. Com respeito à fertilidade dos solos é bastante variada, com certa predominância de média para alta. A área da unidade é recortada por rios perenes, porém de pequena vazão e o potencial de água subterrânea é baixo. A vegetação desta unidade é formada por Florestas Subcaducifólica e Caducifólica, próprias das áreas agrestes. O clima é do tipo Tropical chuvoso, com 
verão seco. A estação chuvosa se inicia em Janeiro/Fevereiro com término em setembro, podendo se adiantar até Outubro (CPRM, 2005).

Nas Superfícies suave onduladas, a onduladas, ocorrem os Planossolos, medianamente profundos, fortemente drenados, ácidos a moderadamente ácidos e fertilidade natural média e ainda os Podzólicos, que são profundos, textura argilosa, e fertilidade natural média a alta. Nas elevações ocorrem os solos Litólicos, rasos, textura argilosa e fertilidade natural média. Nos Vales dos rios e riachos, ocorrem os Planossolos, medianamente profundos, imperfeitamente drenados, textura média/argilosa, moderadamente ácidos, fertilidade natural alta e problemas de sais. Ocorrem ainda afloramentos de rochas (CPRM, 2005).

O município de Pedra Lavrada (figura 8 (c)) está situado na região do Polígono das Secas. Possui clima Semi-árido quente com chuvas de verão. Segundo a divisão do Estado da Paraíba em regiões bioclimáticas o município possui clima 2b-sub-desértico quente de tendência tropical, com 9 a 11 meses secos. A pluviometria média anual é de 359,4 , de distribuição irregular com $79 \%$ de seu total concentrando-se em 4 meses. A temperatura média anual é de $27^{\circ} \mathrm{C}$ à $28^{\circ}$ C. A vegetação é do tipo Caatinga-Seridó (CPRM, 2005). 


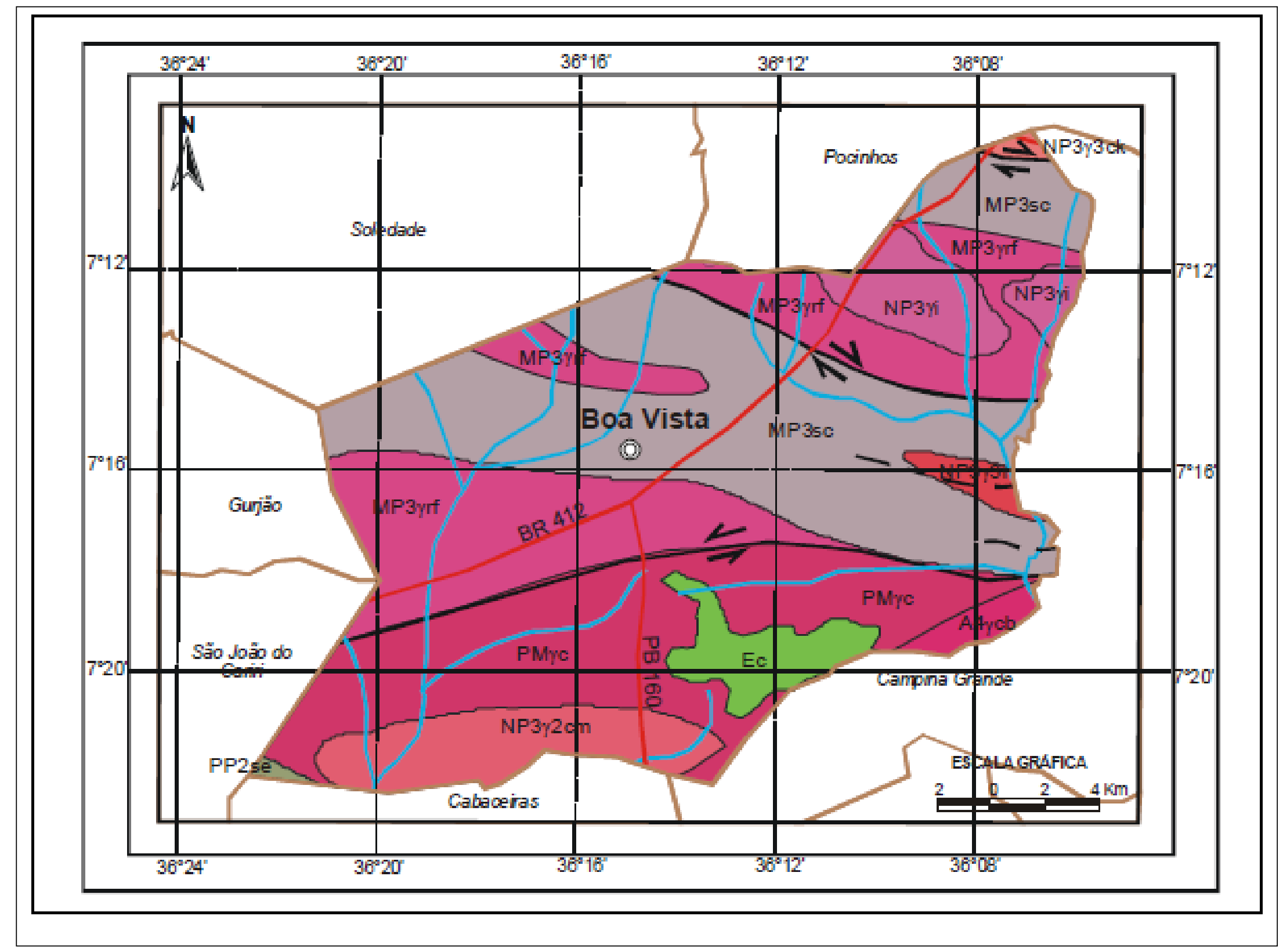

(a) 


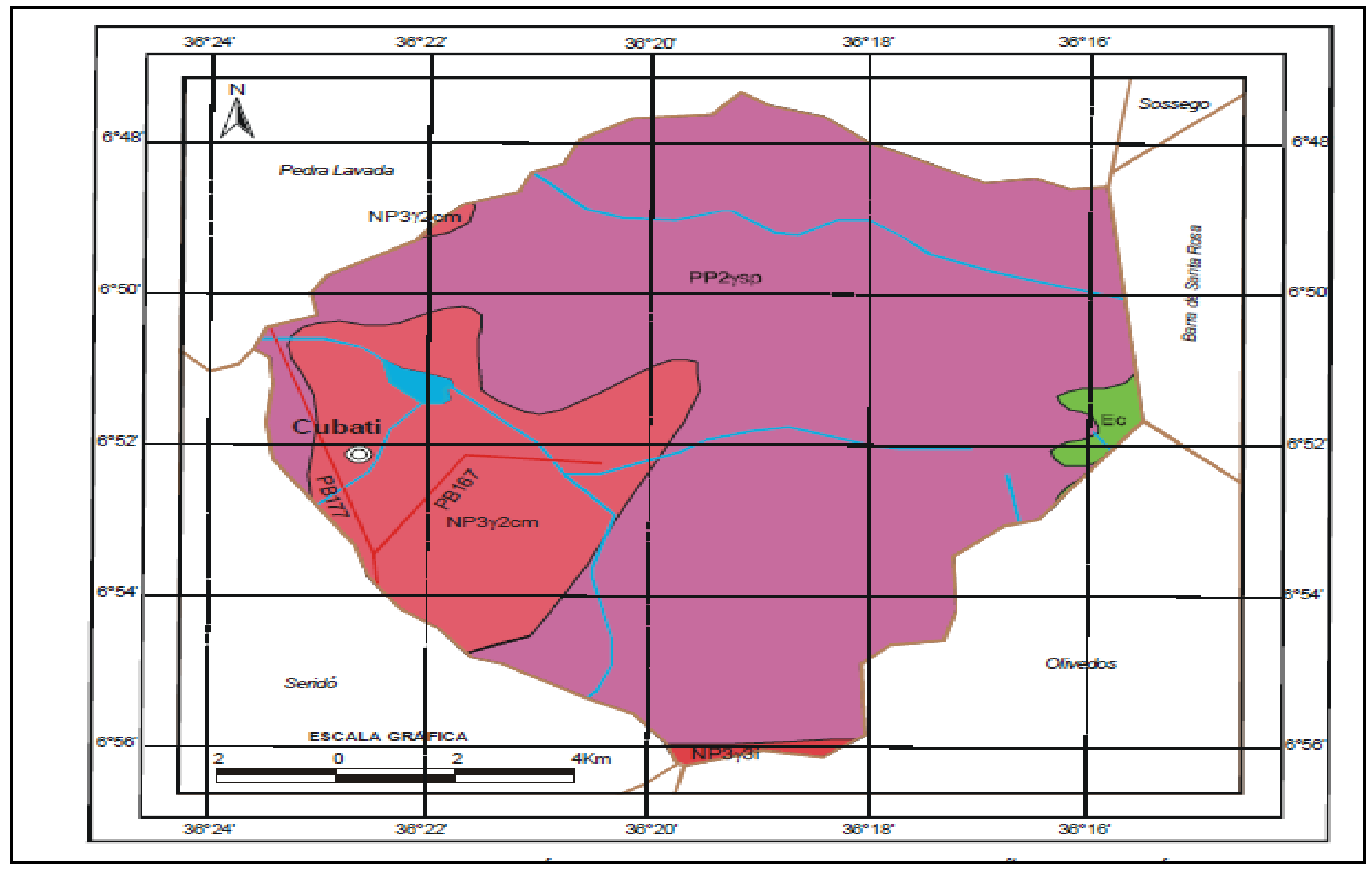

(b) 


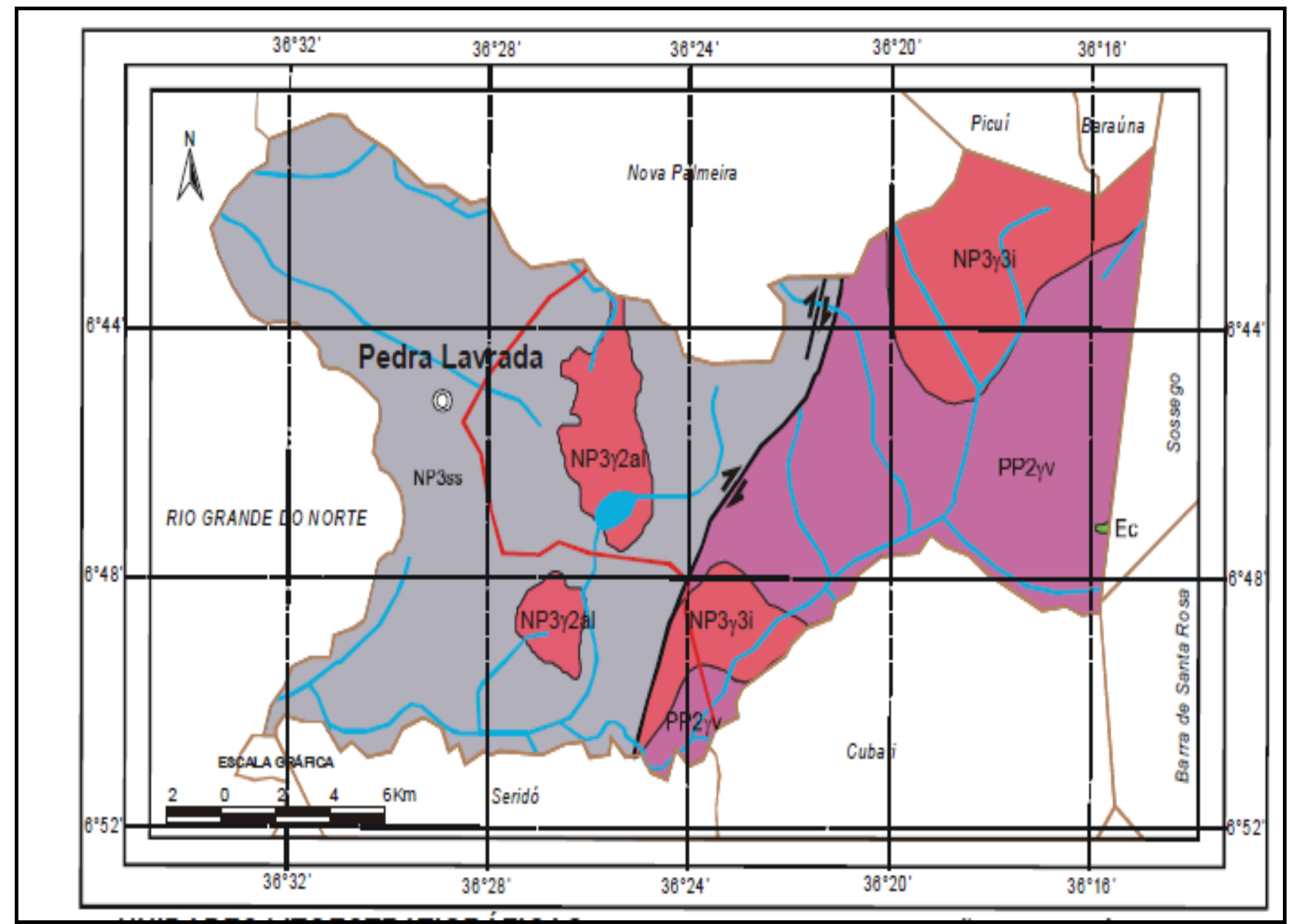

(c)

Figura 8: Mapa geológico da região da Paraíba: (a) Boa Vista; (b) Cubati; (c) Pedra Lavrada. Fonte: CPRM, (2005). 


\subsubsection{Lavra das Bentonitas}

Nas minerações de bentonitas do Estado da Paraíba, a preparação das frentes de lavra (figura 9) tem início com a remoção do capeamento, realizado com tratores e pá carregadeira frontal. O estéril da mina é transportado, por caminhões fora de estrada para locais onde comprovadamente não existiam bentonita.

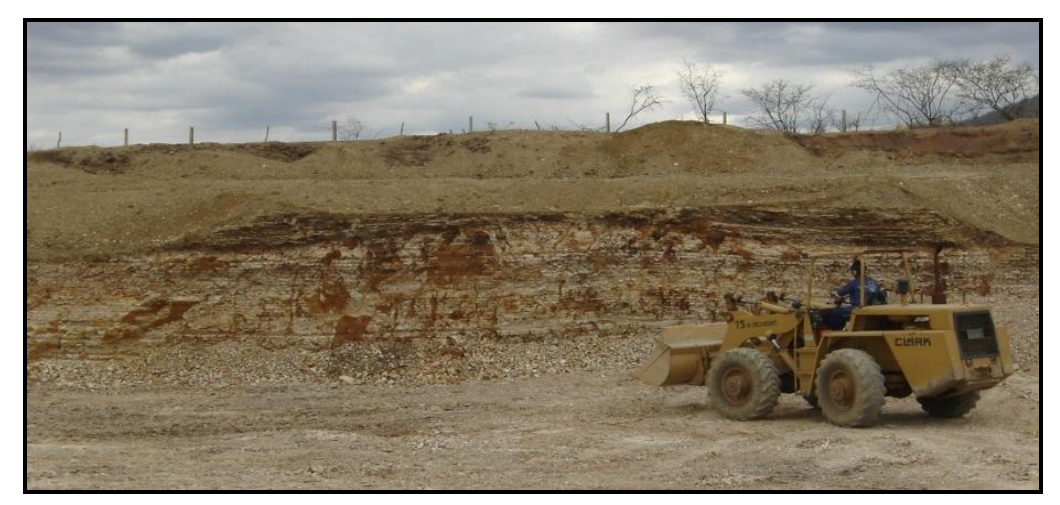

Figura 9: Foto da frente de lavra em Boa Vista-PB.

Fonte: Adriana Silva, (2011).

Na mina Bravo e demais da região de Boa Vista, a lavra é feita a céu aberto, em bancadas que atingem no máximo 2,5m de altura. As operações de desmonte e carregamento são executadas com o auxílio de pá carregadeira e de esteira. A bentonita é lavrada e transportada por caminhões fora de estrada para pilhas de estoque localizadas próximo à mina (figura 10). Esse procedimento deve-se ao fato que, na estação chuvosa, algumas vezes as atividades de lavra são paralisadas devido à impossibilidade de tráfego nas minas (LUZ, 2008).

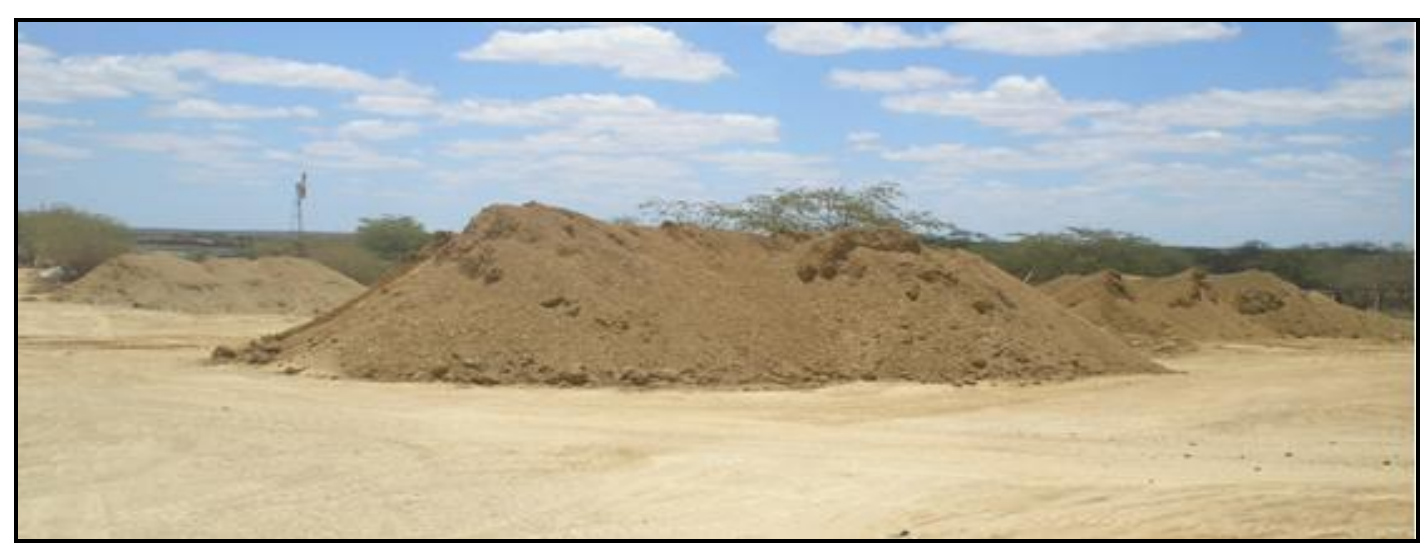

Figura 10: Foto ilustrando as pilhas de estoque em Boa Vista-PB.

Fonte: Adriana Silva, (2011). 


\subsubsection{Processamento / Beneficiamento / Ativação / Produção das Bentonitas}

O Estado da Paraíba tem sido o principal produtor desse bem mineral, tanto na forma bruta quanto beneficiada (ABREU, 1973). Os principais depósitos sedimentares que contêm as bentonitas estão nos municípios de Boa Vista, no município de Cubati e Pedra Lavrada (BARAÚNA, 1993).

O processo de beneficiamento e produção de bentonita consiste de uma série de etapas até chegar na obtenção do produto final, destinado à comercialização de acordo com as especificações técnicas exigidas pelo cliente.

Nas etapas industriais de beneficiamento e produção estão envolvidas as atividades de planejamento, administração até as atividades de controle do processo de fabricação. Basicamente, as etapas mais importantes no processo de beneficiamento e produção são as seguintes:

- Planejamento e Controle da Produção - PCP;

- Controle do Processo de Fabricação.

\section{A) Planejamento e Controle da Producão - PCP}

Esta etapa pode ser considerada a mais importante no processo produtivo, um conjunto de operações logísticas é envolvido a partir de um plano de vendas que determinará a produção mensal a ser atingida. Nesta etapa, são estabelecidos os critérios e controle de produção, bem como a programação de compra de materiais. As fases envolvidas nessa etapa são: Planejamento; Plano de fabricação; Demonstrativo das necessidades de materiais; Programação de produção; Aquisição de materiais; Programação de manutenção; Expedição e transporte.

\section{B) Controle do Processo de Fabricacão}

O controle do processo de fabricação é realizado ao longo de todas as etapas envolvidas no beneficiamento, por meio da inspeção visual e laboratorial. Seu objetivo é evitar falhas durante o processo que geram resultados fora da especificação do produto final. Para um controle eficaz, são realizadas medidas preventivas e corretivas. 
Durante o processo de fabricação existe um acompanhamento constante de cada etapa do ciclo produtivo obedecendo a seguinte sequência: Seleção da matéria-prima; Formulação da matéria-prima; Linha de ativação; Secagem; Moagem, classificação e ensacamento.

\section{B1) Seleção da matéria-prima}

A seleção da matéria-prima dá-se início na exploração da jazida de bentonita com o acompanhamento de um técnico responsável, geralmente um Engenheiro de Minas ou um Geólogo.

Com técnicas adequadas, é retirado o material com auxílio de um trator que remove o capeamento e pá-escavadeira que retira o estéril, despejando-o sobre caminhões caçamba, que levam o material para local que não contenha reserva de bentonita.

Antes da extração, é introduzida uma sonda que permite verificar a disposição em camadas de cada tipo de argila e a profundidade na qual cada uma se encontra na superfície. Dessa forma, a retirada da lavra, com auxílio de equipamentos adequados, é realizada de forma seletiva.

A lavra é feita de acordo com sua qualidade e grau de pureza. Nas minas de Boa Vista - PB, são extraídas as bentonitas denominadas por:

- Chocolate;

- Chocobofe;

- Sortida;

- Bofe e

- Verde Lodo.

Visualmente estas argilas têm as seguintes características:

- Chocolate: Cor marrom com bastante uniformidade e ocorrência de calcedônia (figura 11). 


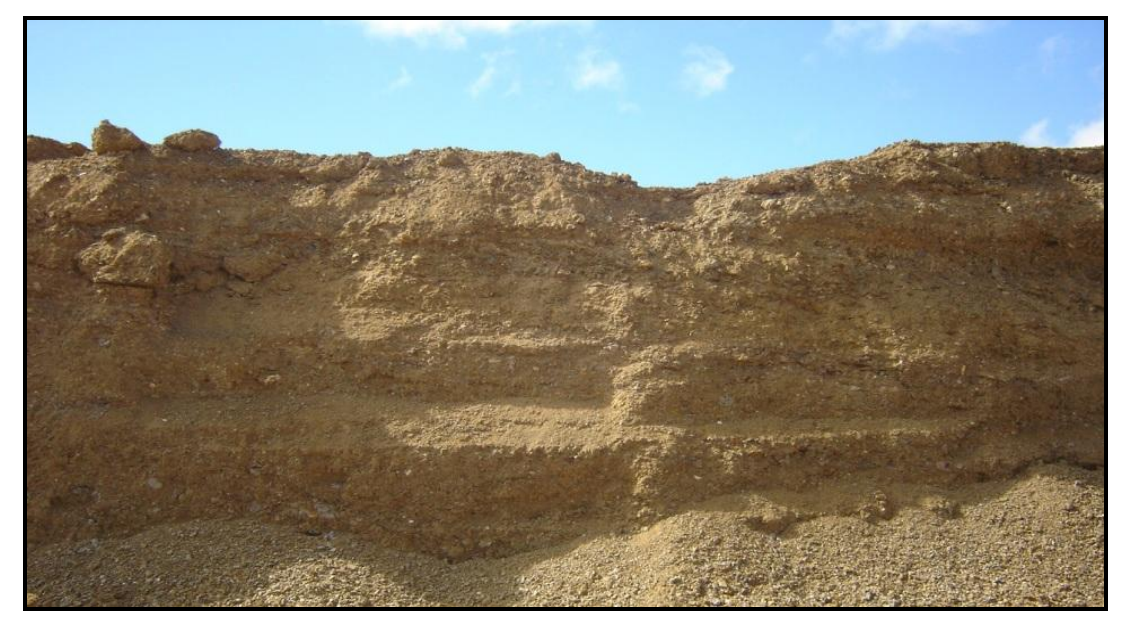

Figura 11: Depósito da Argila Chocolate.

Fonte: Adriana Silva, (2011).

- Chocobofe: Cor marrom claro com pouca uniformidade e alguma presença de calcedônia. A argila Chocobofe (figura 12) é uma mistura natural de chocolate e bofe.

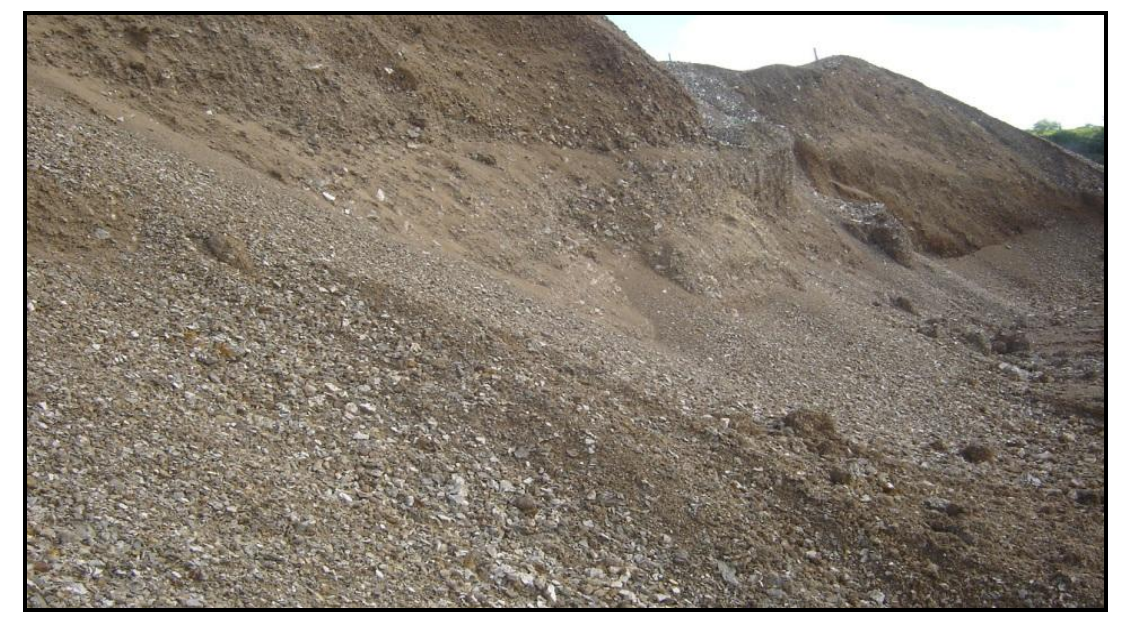

Figura 12: Depósito da Argila Chocobofe no pátio de estocagem.

Fonte: Adriana Silva, (2011).

- Sortida: Cor marrom com pouca uniformidade devido à presença considerável de calcedônia (figura 13). 


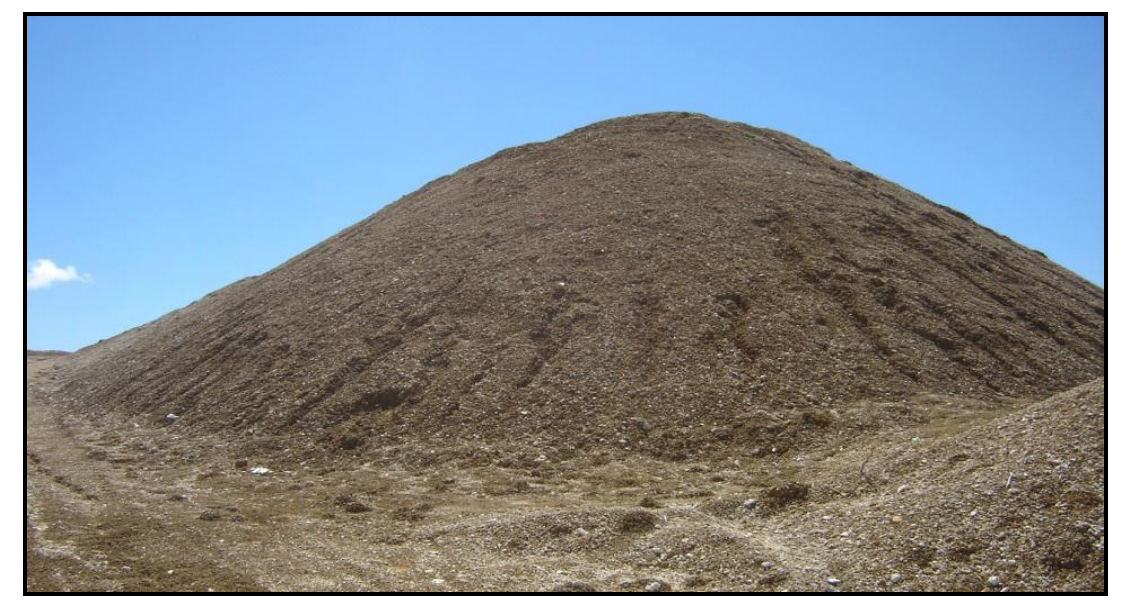

Figura 13: Argila Sortida no pátio de estocagem.

Fonte: Adriana Silva, (2011).

- Bofe: A cor marrom é pouco presente. Ocorre uma predominância da cor branca dos aglomerados argilosos. Considera-se a ausência de calcedônia (figura 14).

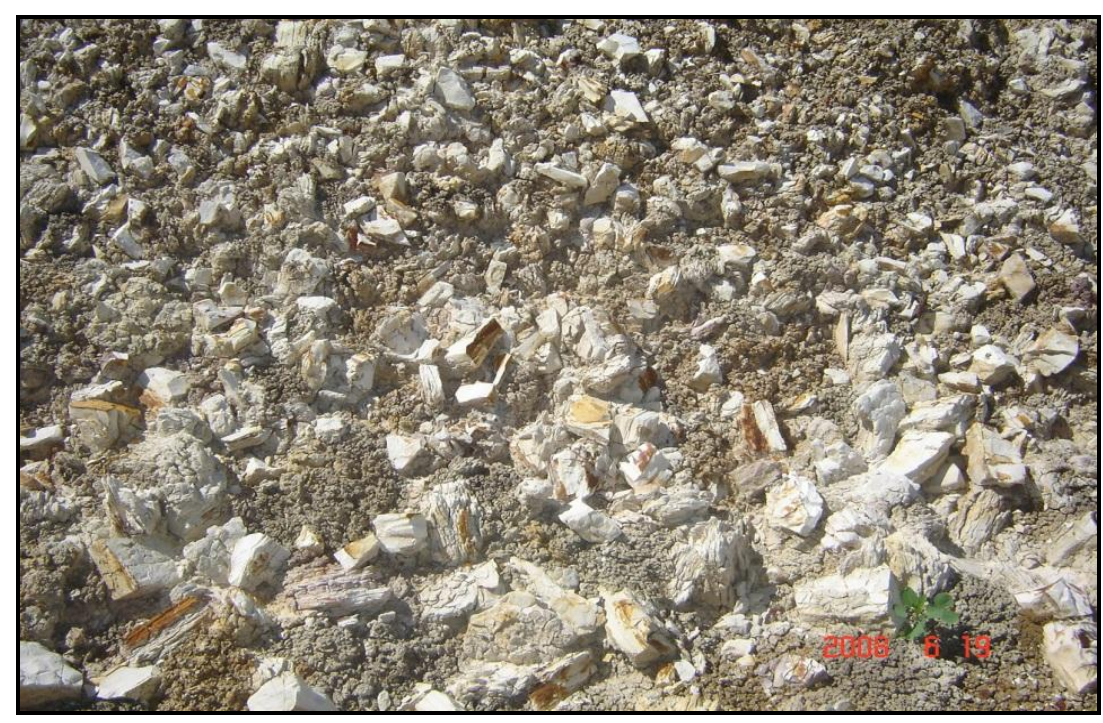

Figura 14: Argila Bofe no pátio de estocagem.

Fonte: Adriana Silva, (2011).

- $\quad$ Argila Verde Lodo: Como o próprio nome afirma, possui cor verde escuro com bastante uniformidade na cor, e pouca presença de calcedônia (figura 15). 


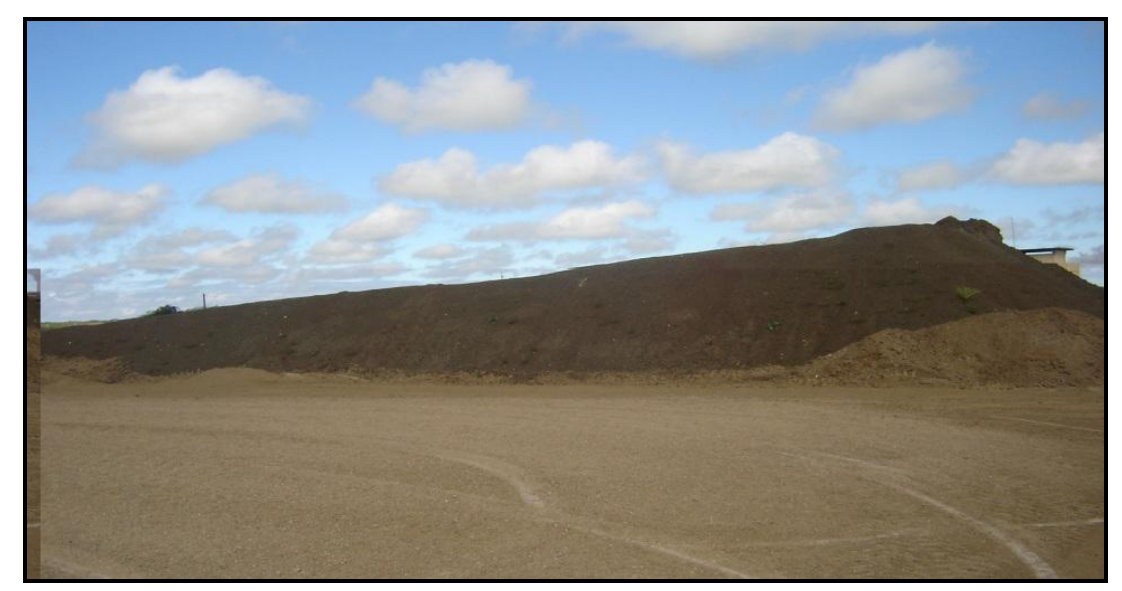

Figura 15: Argila Verde Lodo no pátio de estocagem.

Fonte: Adriana Silva, (2011).

A calcedônia é um contaminante que tem a cor branca com um aspecto de um material oxidado. Sua presença em grandes quantidades interfere nas propriedades do produto beneficiado. Visualmente pode até ser confundido com os fragmentos argilosos predominantes na argila bofe. Porém, a calcedônia é um material de dureza elevada com estrutura totalmente diferente das argilas, enquanto os fragmentos argilosos do bofe são lamelares e desagregam facilmente. Devido a essas características, a distinção entre a argila bofe e calcedônia é facilmente percebida (figura 16).

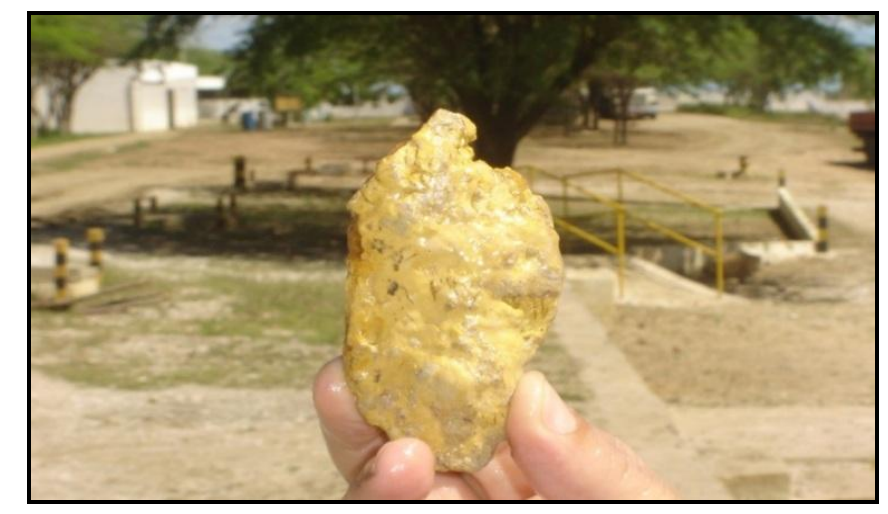

Figura 16: Calcedônia presente na matéria-prima utilizada.

Fonte: Adriana Silva, (2011).

Após a seleção do material na mina, ele é transportado por caminhão caçamba até a unidade de beneficiamento. Antes de ir para os pátios de estoque, é realizada uma verificação visual, comparando-se com amostras-padrão na entrada 
do complexo fabril, para confirmar ou descartar a classificação feita na mina. $\mathrm{Na}$ sequência, é efetuada pesagem, para o controle de entrada de matéria-prima.

No pátio de estocagem, o material "in-natura" é identificado com placas, para garantir a segurança de não ocorrer troca de um tipo de argila por outro na preparação da carga para alimentação da linha de produção.

\section{B2) Formulação da matéria-prima}

A formulação ou traço é a mistura de argilas para o processamento em proporções pré-estabelecidas. As misturas podem ser realizadas por pás mecânicas.

Dependendo do produto comercial que se deseja, não é necessário que haja o processo de formulação ou traço. Nesse caso, apenas um tipo de argila é selecionado para o beneficiamento. Durante a formulação do traço, devido à presença de umidade, a quantidade de argila a ser preparada é superior à produção que se deseja obter, por exemplo: para uma produção de 20 t de argila beneficiada, prepara-se, em média, 24 t de argila "in-natura". A umidade é um parâmetro importante ao longo de todo processo e seu valor varia de acordo com o clima. Em períodos secos, seu valor fica compreendido entre $24 \%$ e $27 \%$; já em períodos chuvosos, entre $28 \%$ e $35 \%$. Com a umidade elevada o material a ser beneficiado passa mais tempo submetido ao processo, devido a um aumento na carga a ser processada.

\section{B3) Linha de ativação}

A linha de ativação é a etapa do ciclo produtivo da bentonita que consiste da: Alimentação e Desagregação; Desintegração; Ativação e Homogeneização; Laminação; Cura.

\section{B3.1) Alimentação e desagregação}


A alimentação é realizada com o derramamento do material preparado na formulação em um "caixão" de alimentação. Na saída do "caixão", um mecanismo mecânico com marteletes desagrega os fragmentos argilosos chamados de torrões. Nesta etapa, inicia-se uma diminuição na granulometria do material. O material desagregado segue em uma esteira que o conduz para a fase de desintegração, antes passando por um separador magnético que tem a função de extrair partículas de materiais metálicos contidos na matéria-prima.

\section{B3.2) Desintegração}

Nesta etapa, é realizada a fragmentação do material de forma mais acentuada em relação a desagregação, obtendo-se uma granulometria apropriada para a ativação e homogeneização, com a utilização de um desintegrador mecânico. Após passar por esta fase, o material segue em esteira para a etapa de ativação e homogeneização. É realizada uma inspeção visual para a retirada manual de calcedônia, o que não foi possível nas etapas anteriores (figura 17).

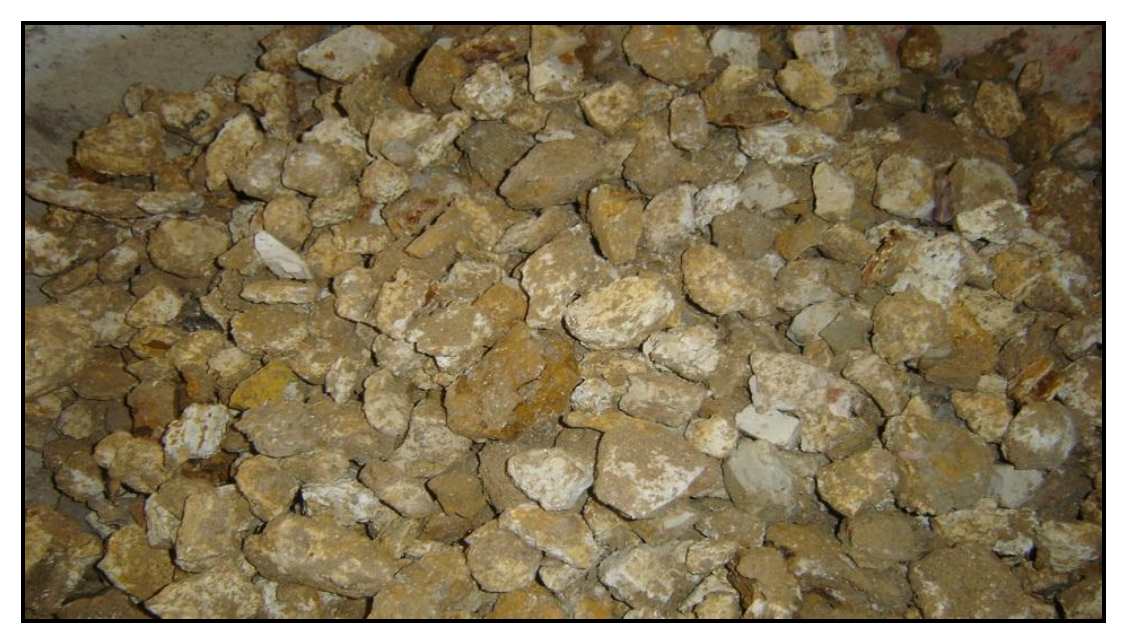

Figura 17: Calcedônia retirada manualmente durante o processo.

Fonte: Adriana Silva, (2011).

\section{B3.3) Ativação e homogeneização}

A bentonita oriunda das jazidas de Boa Vista - PB é de origem cálcica, para seu aproveitamento em determinadas aplicações industriais e tecnológicas, é necessário que haja um processo de modificação química para transformar a bentonita cálcica natural em bentonita sódica ativada. Esse processo de 
transformação denomina-se de "ativação", consistindo na etapa mais importante do beneficiamento das bentonitas da Paraíba (ALMEIDA, 2008).

As formas mais tradicionais de ativação são por meio seco e meio úmido. A ativação por meio seco tem um processo mais lento, devido o tempo para troca catiônica ser maior. Nesse tipo de ativação, a argila é espalhada de forma rente ao chão, onde o carbonato de sódio é acrescentado sobre o material natural.

Produtivamente, a ativação a seco é viável para beneficiadoras que possuem grande produtividade e capital financeiro que permitam a formação de grandes estoques de produto acabado sem necessidade de comercialização imediata. $\mathrm{Na}$ ativação por meio úmido, o carbonato de sódio é misturado com água formando solução aquosa para mistura com a argila, sendo este processo mais rápido, por possibilitar um período de ciclo produtivo mais curto e o mais utilizado na maioria das empresas. A transformação ocorre devido à substituição do íon cálcio da bentonita natural pelo íon sódio presente na solução aquosa de carbonato de sódio, chamada de barrilha. $\quad O$ processo tem início a partir do momento em que o material oriundo do desintegrador, transportado por esteira, é despejado em um misturador. No misturador, o material natural recebe a adição da barrilha e ocorre a homogeneização realizada por um mecanismo de parafuso sem-fim adaptado com lâminas circulares acopladas no sentido longitudinal do corpo do parafuso. A adição de barrilha é controlada por mecanismos de passagem, chamados de rotâmetros, que recebem a solução aquosa armazenada em reservatórios e regulam a vazão, permitindo que a ativação seja realizada de acordo com a conformidade. Para cada variedade de produto comercial beneficiado ocorre uma preparação de barrilha e uma relação de vazão, para diferentes índices de ativação. Nesse estágio, a homogeneização tem papel importante na substituição do íon cálcio pelo íon sódio, permitindo uma boa troca catiônica. O acompanhamento laboratorial é fundamental para certificação de que a ativação se encontra dentro do padrão para o tipo de produto em processo.

\section{B3.4) Laminação}


No processo de laminação, a argila ativada passa por uma etapa na qual os rolos cilíndricos compactam a argila ativada, permitindo um maior contato entre as camadas da argila e a solução de barrilha. A laminação também tem a função de conformar a argila, conferindo-Ihe uma espessura fina adequada para o processo de cura e secagem.

\section{B3.5) $\underline{\text { Cura }}$}

Após a laminação, o material é transportado para pátios de cura (figura 18) onde permanece em meio ambiente por um período de três a seis dias, dependendo do tipo de produto que está sendo beneficiado e da necessidade da produção. Durante a cura, ocorre uma maior interação entre a argila e barrilha, consequentemente melhorando a troca catiônica, verificada laboratorialmente, encerrando-se o processo de ativação. Dependendo das especificações do produto em beneficiamento a cura não é realizada (ALMEIDA, 2008).

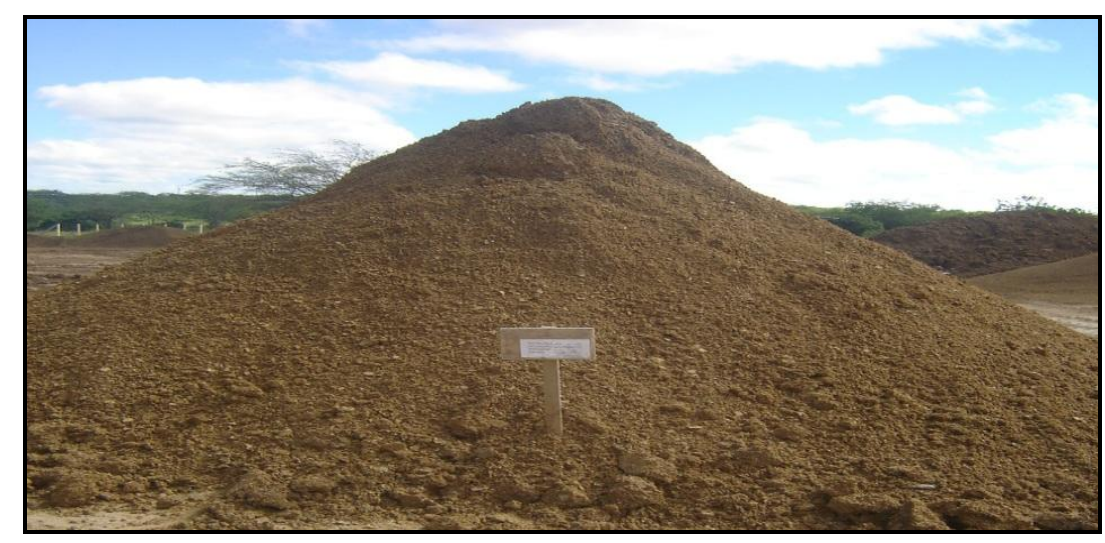

Figura 18: Material ativado em processo de cura .

Fonte: Adriana Silva, (2011).

\section{B3.6) Secagem}

O processo de secagem tem por objetivo conferir ao material ativado, com ou sem cura, umidade ideal para a etapa de moagem e classificação. A secagem pode ser realizada de forma natural ou mecânica.

$\mathrm{Na}$ secagem natural (figura 19), o material é exposto ao sol em áreas apropriadas, chamadas de lajões, para evaporação da umidade em excesso. Nesse 
processo, os materiais granulados são transportados por caminhões caçambas e espalhados nos lajões, em finas camadas, com espessuras de 10 a $15 \mathrm{~cm}$.

É necessário que haja uma manutenção para remover o material com utilização de um arado entre períodos médios de $10 \mathrm{~h}$. A secagem se processa por períodos de três dias, durante os quais são feitas coletas para verificação da umidade em laboratório. A faixa de umidade aceita na secagem natural está compreendida entre $14 \%$ e $16 \%$.

A secagem mecânica é realizada durante períodos de chuva em fornalha por meio de mecanismos de troca de calor condutivo e convectivo no interior de um cilindro rotativo. Geralmente a temperatura de trabalho varia entre $400^{\circ} \mathrm{C}$ e $500^{\circ} \mathrm{C}$, com um tempo de permanência, do material no cilindro rotativo, de $25 \mathrm{~min}$. A umidade do material após secagem compreende a faixa de $17 \%$ e $18 \%$ (ALMEIDA, 2008).

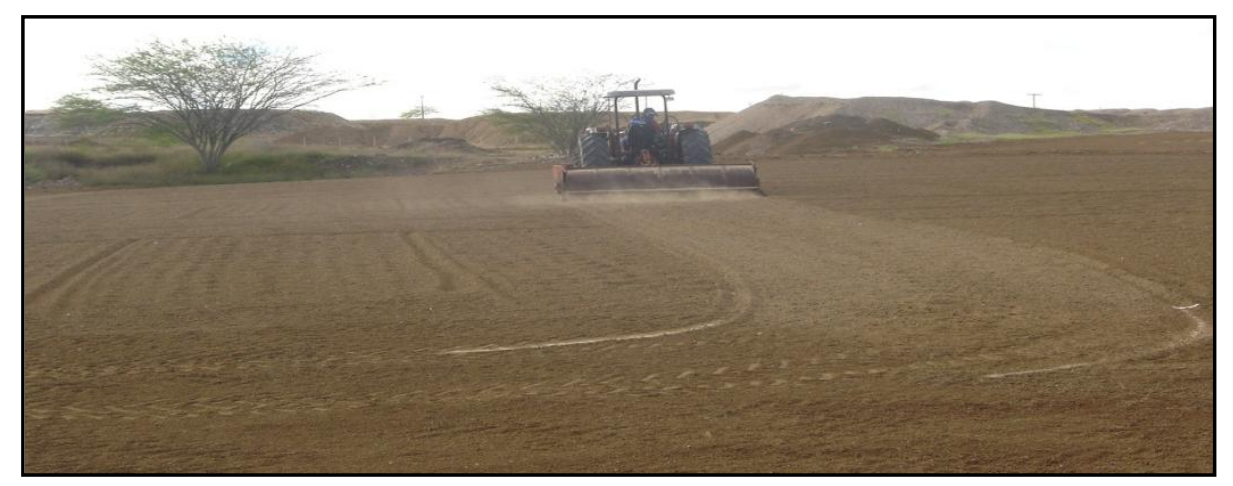

Figura 19: Processo de secagem natural .

Fonte: Adriana Silva, (2011).

\section{B3.7) Moagem, Classificação e Ensacamento}

Esta constitui a última etapa do processo de fabricação na qual os produtos são definitivamente embalados com a granulometria desejada. O sistema de moagem é formado basicamente por elevador de concha, silos de armazenagem, moinho de rolos, ciclone classificador e coletor de pó. O funcionamento é controlado em sala de monitoração onde, por meios de painéis de controle, o operador programa a granulometria e acompanha as variáveis e falhas do processo. $\mathrm{O}$ objetivo da moagem é reduzir os grânulos do material seco em granulometrias de 
acordo com a especificação do produto em beneficiamento. As granulometrias mais comumente processadas são as de abertura 200 mesh e 325 mesh, com umidade final entre $10 \%$ e $12 \%$. O bom desempenho da moagem está diretamente ligado à umidade do material em processo. Os materiais que sofreram secagem natural permitem uma maior produtividade do que os materiais que foram submetidos à secagem mecânica, por apresentarem uma menor umidade. Dessa forma, um material que tenha sido secado mecanicamente, com umidade entre $17 \%$ e $18 \%$, provoca uma queda na produtividade em torno de $20 \%$, por necessitar de um tempo maior para seu processamento.

A moagem tem início na alimentação do elevador de concha, com material ativado, que realiza o transporte para o silo de armazenagem, o qual tem a função de alimentar o moinho de rolos. No moinho de rolos, o material sofre pulverização mecânica, reduzindo as partículas da argila a dimensões desejáveis em forma de um pó fino. Um sistema pneumático conduz o pó para ciclones que realizam a classificação granulométrica por diferença de densidade . O material de classificação desejada é sugado por um coletor de pó que enche as embalagens dos produtos, encerrando-se, nesta etapa, o ciclo de fabricação (figura 20).

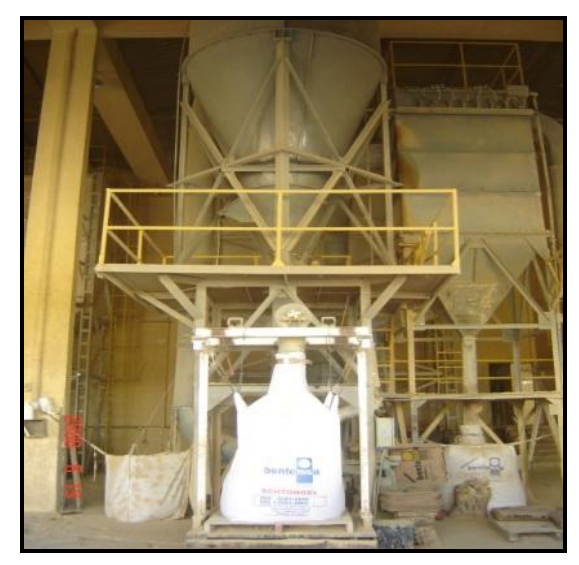

Figura 20: Moinho classificador.

Fonte: Adriana Silva, (2011).

\subsubsection{Reservas das Bentonitas}

As principais jazidas de bentonita em operação no Brasil estão localizadas no município de Boa Vista, Estado da Paraíba (LUZ, 2008). 
$\mathrm{Na}$ tabela 2, estão listadas as reservas brasileiras de bentonita e argilas descorantes, onde as reservas medidas e indicadas somam 55,3 e 34,2 milhões de toneladas, respectivamente. De acordo com o Sumário Mineral - 2008, as reservas oficiais medida e indicada brasileiras alcançaram, respectivamente 41,4 e 27,5 milhões de toneladas em 2007, havendo redução de $25 \%$ e $19 \%$ das reservas medidas e indicadas, respectivamente, em relação aos valores consolidados de 2005 pelo Anuário Mineral Brasileiro, 2006.

Tabela 2: Reservas brasileiras de bentonita e argilas descorantes- 2005.

\begin{tabular}{|c|c|c|c|c|}
\hline UNIDADES DA & \multicolumn{4}{|c|}{ RESERVAS } \\
\hline MUNICÍPIOS & $\begin{array}{l}\text { MEDIDA } \\
(\mathrm{t})\end{array}$ & $\begin{array}{l}\text { INDICADA } \\
(\mathrm{t})\end{array}$ & $\begin{array}{c}\text { INFERIDA } \\
(\mathrm{t})\end{array}$ & $\begin{array}{l}\text { LAVRÁVEL } \\
\text { (t) }\end{array}$ \\
\hline Bahia & 3.704 .192 & - & - & 3.704 .192 \\
\hline Paraíba & 10.350 .046 & 4.443 .876 & 357.348 & 5.283 .841 \\
\hline Piauí & 11.636 .190 & 3.670 .036 & 1.800 .000 & 15.306.226 \\
\hline Paraná & 16.000 .000 & 687.942 & - & 10.000 .000 \\
\hline São Paulo & 13.641 .325 & 25.425 .800 & 16.541 .000 & 10.458 .075 \\
\hline $\begin{array}{c}\text { Bentonita e Argilas } \\
\text { Descorantes }\end{array}$ & 55.331 .753 & 34.227 .654 & 18.698.348 & 44.752 .334 \\
\hline
\end{tabular}

Fonte: Anuário Mineral Brasileiro, (2006).

As principais fontes de bentonita em operação no Brasil estão localizadas no município de Boa Vista, Estado da Paraíba. Existem outros depósitos importantes, destacando-se o município de Vitória da Conquista na Bahia, onde está instalada a Companhia Brasileira de Bentonita- CBB, pertencente a Sud Chemie, multinacional alemã de indústria de aditivos químicos, a mesma possui uma capacidade instalada para produção de 1000.000 t/ano (COELHO;CABRAL, 2010).

Os Estados produtores de bentonita são: Paraíba, São Paulo e Bahia. De acordo com o Sumário Mineral 2009, a produção estimada de bentonita bruta atingiu 340.141 t, representando um aumento de 30,8 \% em relação a 2007. O Estado da Paraíba produziu 77,3 \% da bentonita bruta brasileira, São Paulo correspondeu 11,7 
\% e Bahia com $11 \%$. A maior produtora de bentonita bruta é a Bentonit União Nordeste com 48,1\% em 2008.

O destino da bentonita bruta se distribuiu entre os Estados da Paraíba (96,5 $\%)$, Rio de Janeiro (3,1 \%), Paraná (0,2 \%). A bentonita bruta na Paraíba é comercializada em quantidades no próprio Estado e destinada às empresas para a sua ativação e posterior venda aos demais mercados nacionais. O município de Boa Vista foi o responsável por $88 \%$ das vendas de bentonita bruta, em 2007. Para Campina Grande foram destinados 8,9 \% e para Pocinhos 3,1 \% (COELHO, 2010).

A produção interna de bentonita beneficiada em 2008 (moída, seca e ativada) alcançou 265.032 t, representando um crescimento de 9,8 \% em relação a 2007, que foi de 238.746 t. A distribuição geográfica da produção de bentonita moída seca deu-se da seguinte forma: São Paulo 99,8 \% e Paraná 0,2 \%. A produção de bentonita ativada distribui-se entre o Estado da Paraíba com 86 \% e Bahia com 14 \%. O destino de bentonita beneficiada (moída seca) se distribuiu nos seguintes Estados: São Paulo (52,2 \%), Minas Gerais (28,6 \%), Paraná (8\%), Santa Catarina $(0,1 \%)($ COELHO;CABRAL, 2010).

O destino da bentonita ativada foi apurado entre os seguintes Estados: Espírito Santo (38,4 \%), Minas Gerais (25,5 \%), São Paulo (14,8 \%), Rio Grande do Sul $(12,1 \%)$ e Santa Catarina $(9,1 \%)($ COELHO;CABRAL, 2010).

\subsubsection{Os Principais Depósitos de Bentonitas na Paraíba}

\subsubsection{Bentonitas de Boa Vista (PB)}

O Município de Boa Vista (figura 21) encontra-se localizado na mesorregião do Agreste da Paraíba, mais precisamente na microrregião de Campina Grande. Faz fronteira ao leste com o município de Gurjão e São João do Cariri, ao norte com os municípios de Soledade e Poçinhos e ao sul com os municípios de Cabaceiras e Boqueirão (GOPINATH et. al., 2003).

Boa Vista - PB possui uma área territorial de 446,3 $\mathrm{km}^{2}$, situada a cerca de 48 km de Campina Grande e 173 km de João Pessoa. O acesso da sede desse município à cidade polarizadora à capital do Estado da Paraíba dá-se através de 
rodovias federais pavimentadas, como a BR-230 e a BR-412 que se liga à primeira na localidade Farinha, entre o seu território, o município de Poçinhos e o município de Campina Grande. Tais recursos se convertem em importantes articuladores de Boa Vista com o Estado da Paraíba, a região Nordeste e o país. Certamente esses recursos são utilizados para distribuir a bentonita extraída, beneficiada e processada em seu território nos mercados de consumo em diversos pontos do país (GOPINATH et. al., 2003).

As bentonitas de Boa Vista-PB são de origem continental, vulcano-sedimentar (derrames de lavas basálticas), que preencheram lagos e canais. Ao contrário das bentonitas americanas (bacias marítimas), as argilas brasileiras são predominantemente cálcicas, sendo necessário transformá-las em sódicas, empregando-se o carbonato de sódio (como algumas bentonitas americanas, argentinas e alemãs) (BENTONIT, 2005).

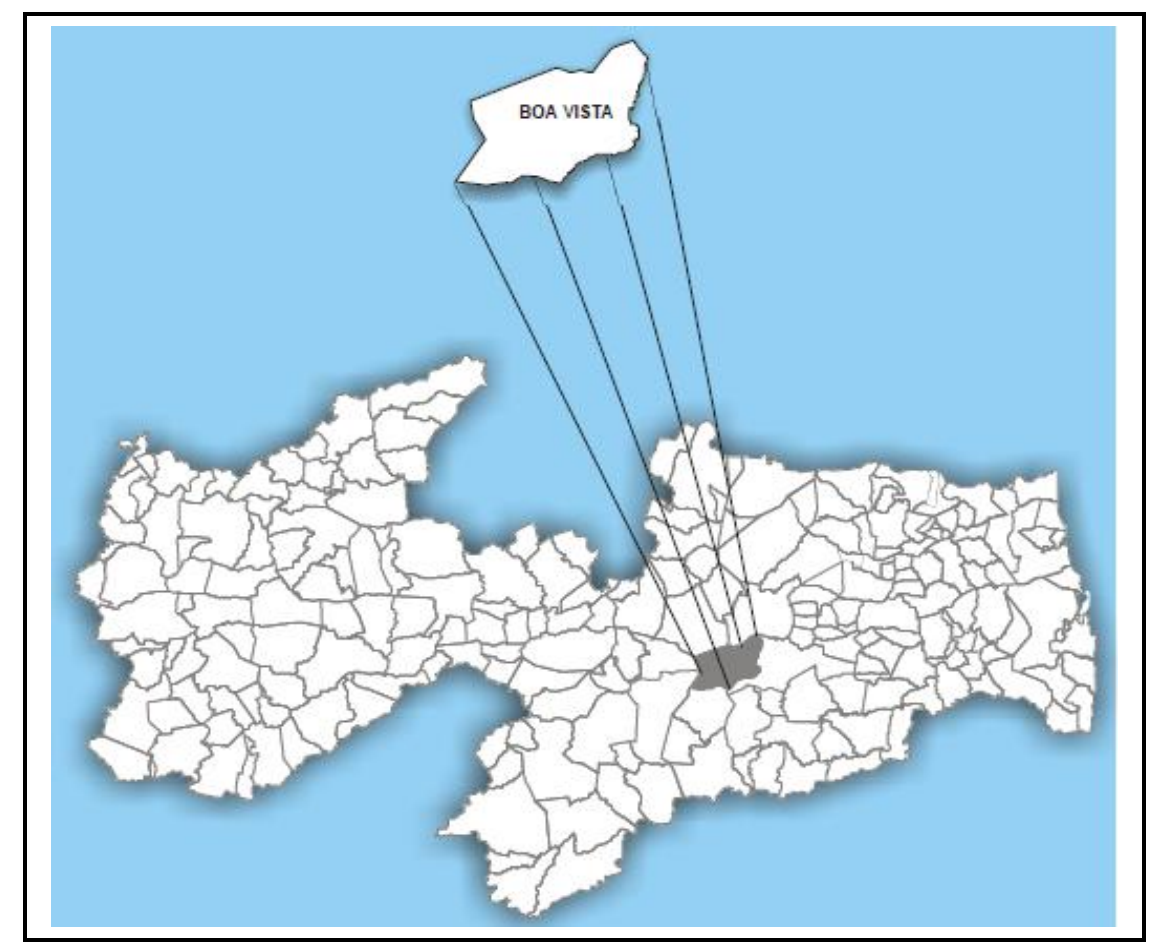

Figura 21: Localização da cidade de Boa Vista - PB no mapa da Paraíba.

Fonte: CPRM, (2005).

Mineralogicamente essas bentonitas caracterizam-se pela presença dos vários tipos de argilominerais e de seus respectivos teores e transformações resultantes do seu aquecimento. Em condições idênticas a bentonita paraibana (Boa Vista), quando comparada com a norte-americana (Wyoming), destaca-se em alto grau pelo seu rendimento ou maior viscosidade aparente (DOLOMIL, 2005). 
A região de Boa Vista (Paraíba) concentra cerca de $60 \%$ das reservas brasileiras de bentonitas. Os principais depósitos encontram-se associados a pequenas bacias de forma circular, distribuídas geograficamente, nas localidades de Bravo, Lages, Lagedo, Primavera e Juá, estendendo-se numa distância de 10 km. As rochas dessa região são originadas do derrame basáltico do terciário no lado leste e os granitos e gnaisses do Pré-Cambriano a oeste (GOPINATH et. al., 2003). As jazidas de bentonitas do município de Boa Vista-PB (figuras 22 a 27) são as únicas produtoras, em grande escala, de bentonitas sódicas sintéticas brasileiras. Nas condições em que são encontradas na natureza são parcialmente cálcicas quanto aos cátions trocáveis, e por reação química de troca catiônica com carbonato de sódio, transformam-se em bentonitas sódicas (SANTOS et. al., 1980). Dentre as principais minas destacam-se: 


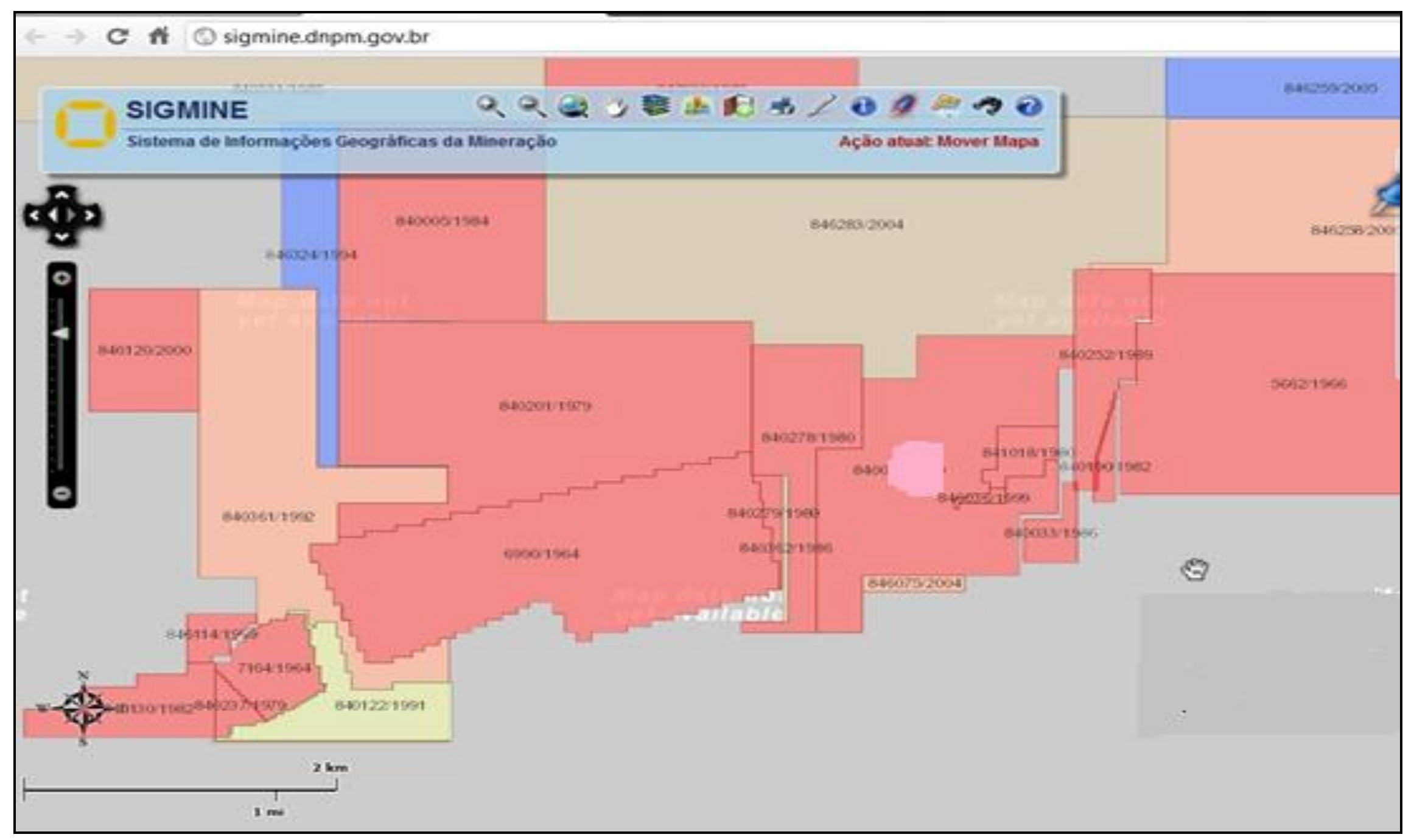

Figura 22: Localização das minas na região de Boa Vista - PB.

Fonte: DNPM, (2011). 
MINA BRAVO - Dentre os depósitos de bentonitas de Boa Vista-Paraíba (figura 23), o Sítio Bravo é o que apresenta maior diversificação de cores e tonalidades, entretanto, as bentonitas que predominam correspondem às que regionalmente são conhecidas como "bofe". Essas argilas são leves e de cores claras (predominantemente creme-clara); fissuram-se facilmente quando expostas ao sol (SANTOS et. al., 1980). Podem ser encontradas outras variedades de argilas denominadas localmente por: "verde-lodo", " chocolate", " chocobofe" e "bofe". As argilas desse depósito são na sua grande maioria comercializadas pela empresa BUN - Bentonit União Nordeste.

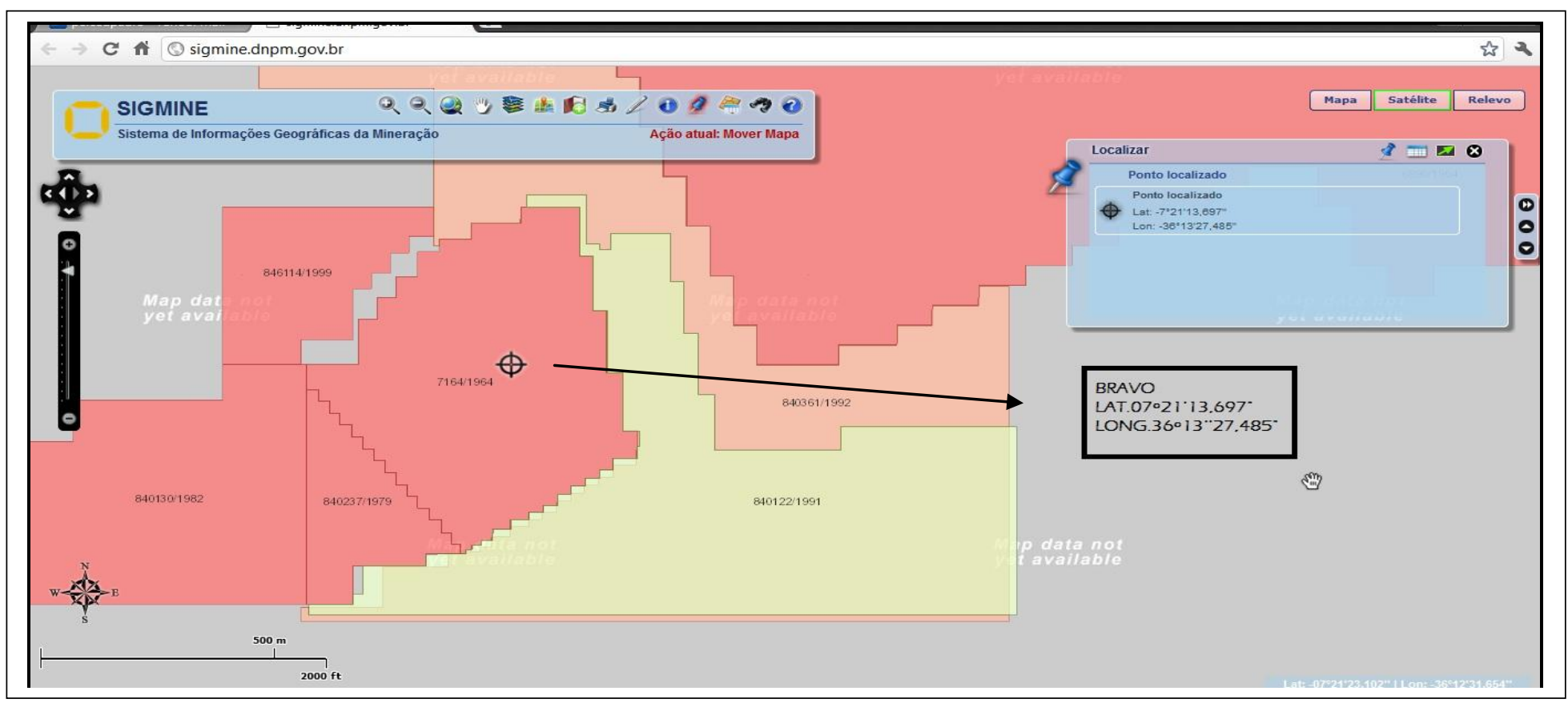

Figura 23: Localização da mina Bravo.

Fonte: DNPM, (2011). 
MINA LAGES - Nas minas do Sítio Lages (figura 24) há uma diversificação de cores e tonalidades, podem ser encontradas as bentonitas denominadas localmente por: "verde-lodo", "cor chocolate", "cor chocobofe" e "cor bofe" (SANTOS et. al., 1980). As argilas desse depósito são na sua grande maioria comercializadas pela empresa BENTONISA- Bentonita do Nordeste S.A.

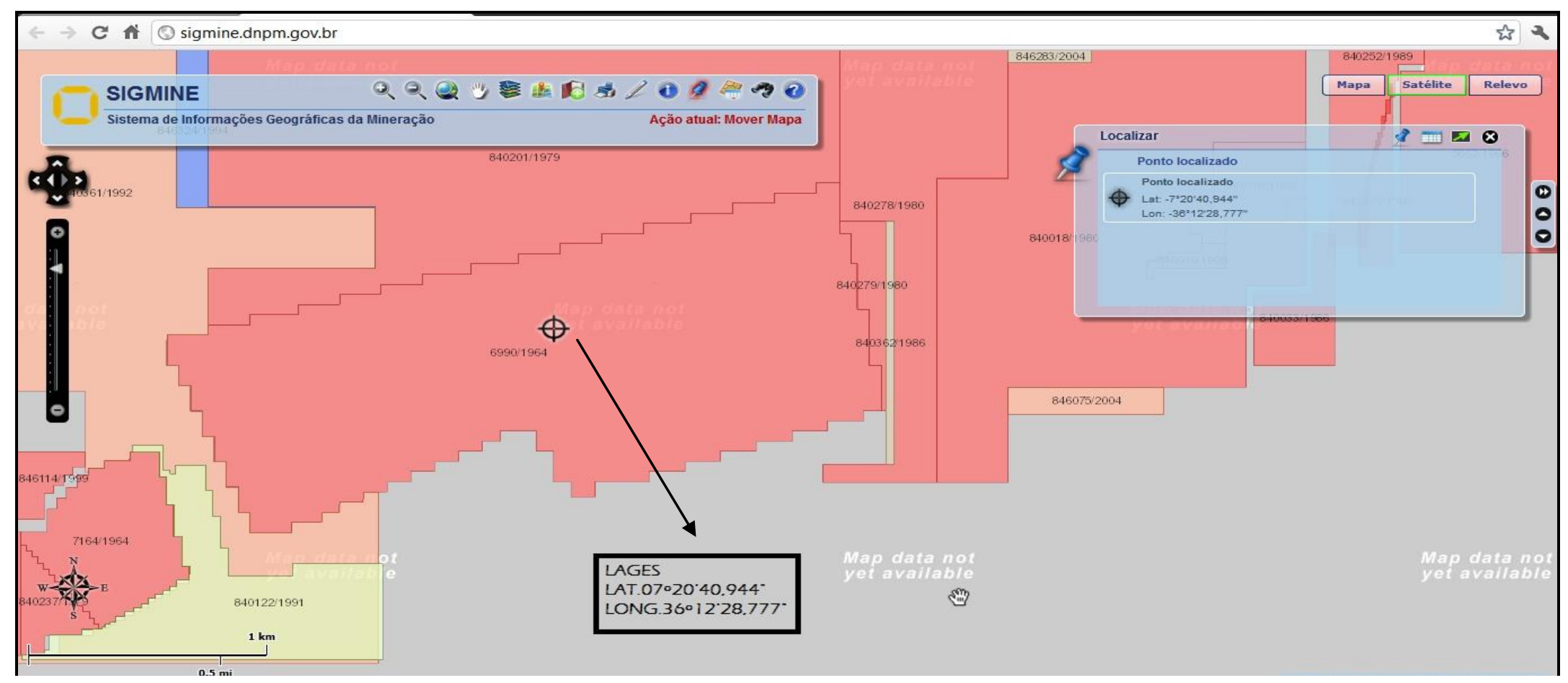

Figura 24: Localização da mina Lages.

Fonte: DNPM, (2011). 
MINA LAGEDO - Nas minas do Sítio Lagedo (figura 25) podem ser encontradas as bentonitas denominadas localmente por: "verde-lodo", "cor chocolate", "cor chocobofe" e "cor bofe" (SANTOS et. al., 1980). As argilas desse depósito são na sua grande maioria comercializadas pela empresa BENTONISA- Bentonita do Nordeste S.A.

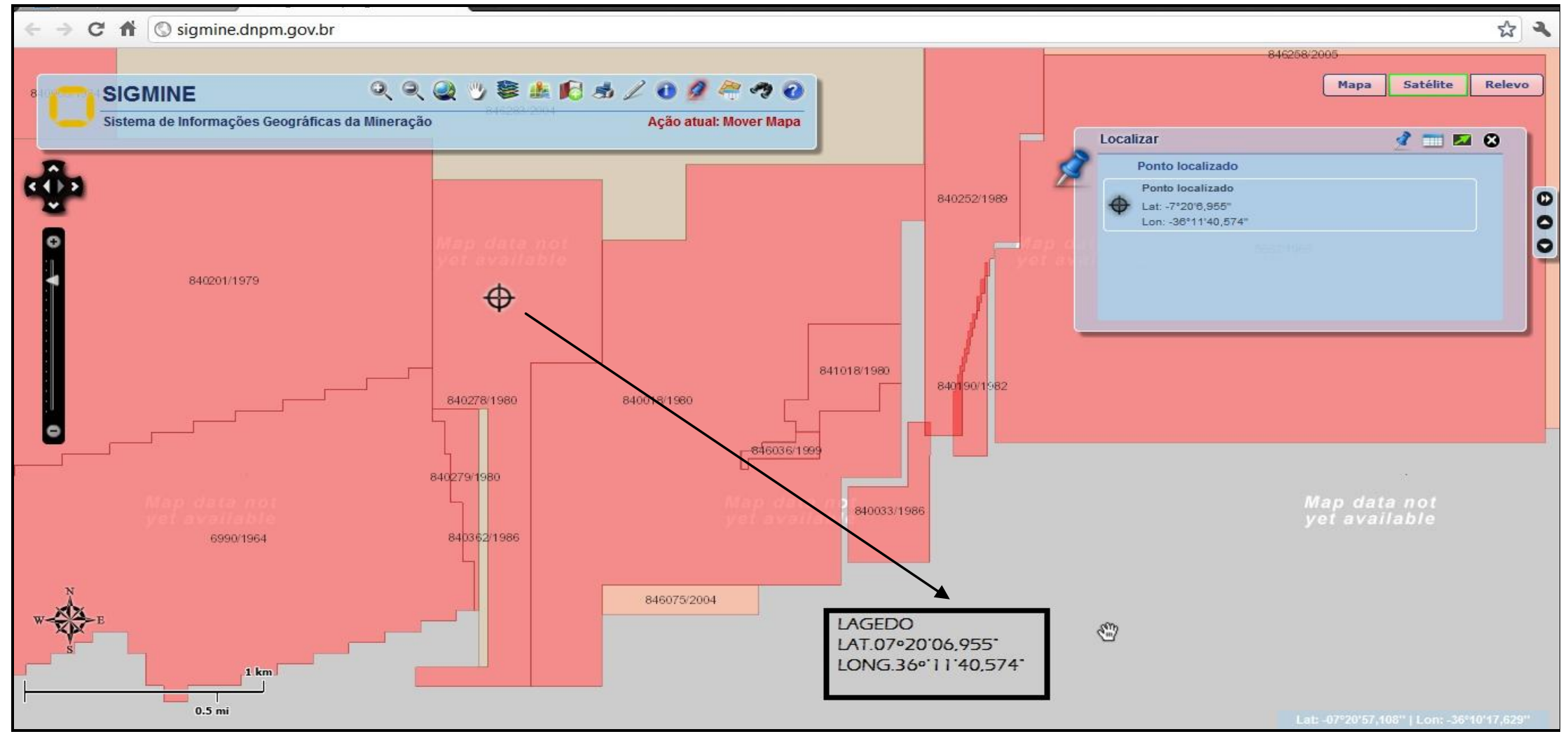

Figura 25: Localização da mina Lagedo.

Fonte: DNPM, (2011). 
MINA PRIMAVERA - No Sítio Primavera (figura 26), podem ser encontradas as argilas denominadas localmente por: "verde-lodo", "cor chocolate", "cor chocobofe" e "cor bofe" (SANTOS et. al., 1980). As argilas desse depósito são na sua grande maioria comercializadas pela empresa BUN - Bentonit União Nordeste.

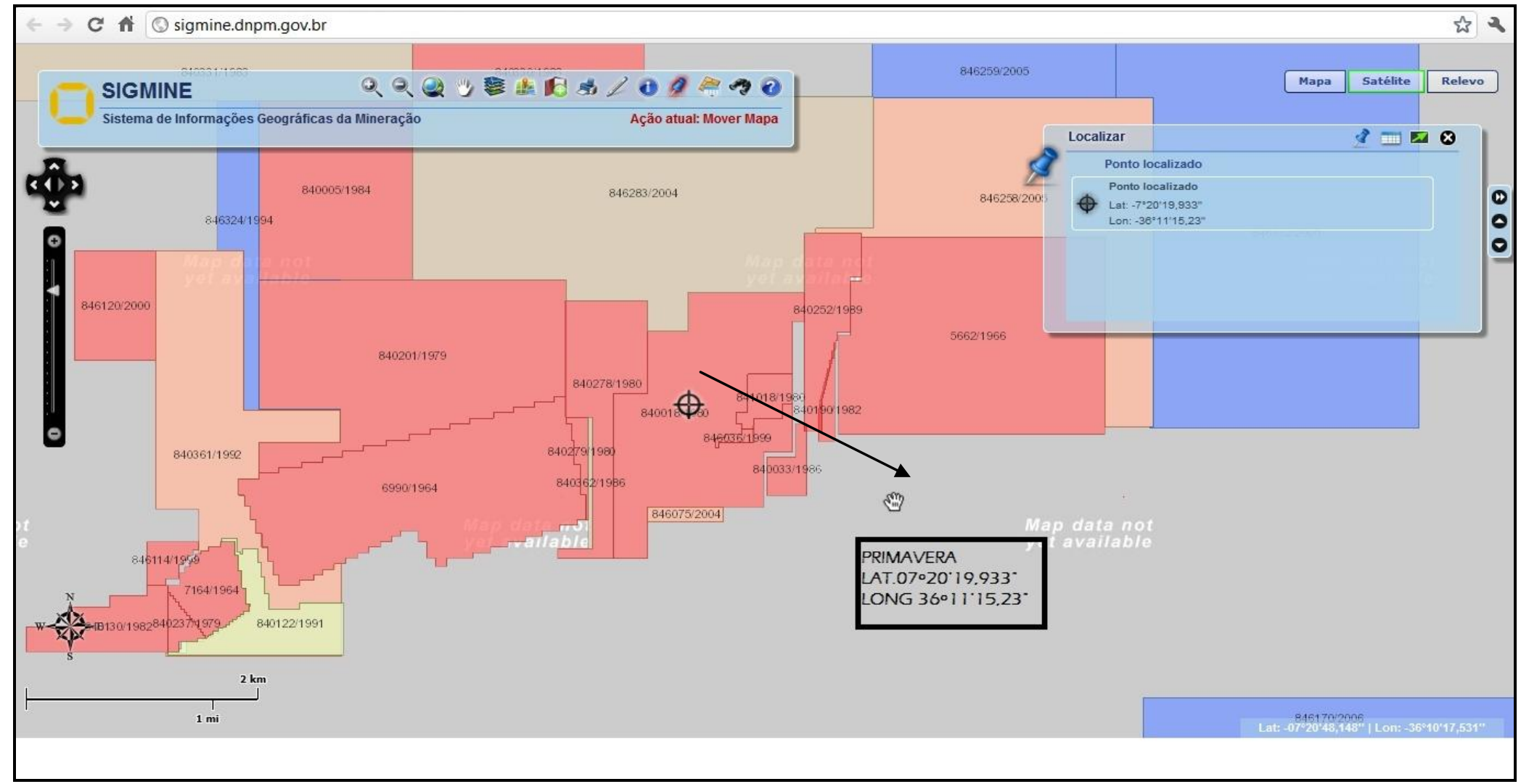

Figura 26: Localização da mina Primavera.

Fonte: DNPM, (2011). 
MINA JUÁ - O depósito do Sítio Juá (figura 27), que está situado aproximadamente a dois quilômetros de Lages, é semelhante aos depósitos dessa localidade. Observa-se, entretanto, uma maior predominância em Juá, das argilas de cor chocolate-escura, as quais são extraídas para usos industriais nobres (SANTOS et. al., 1980).

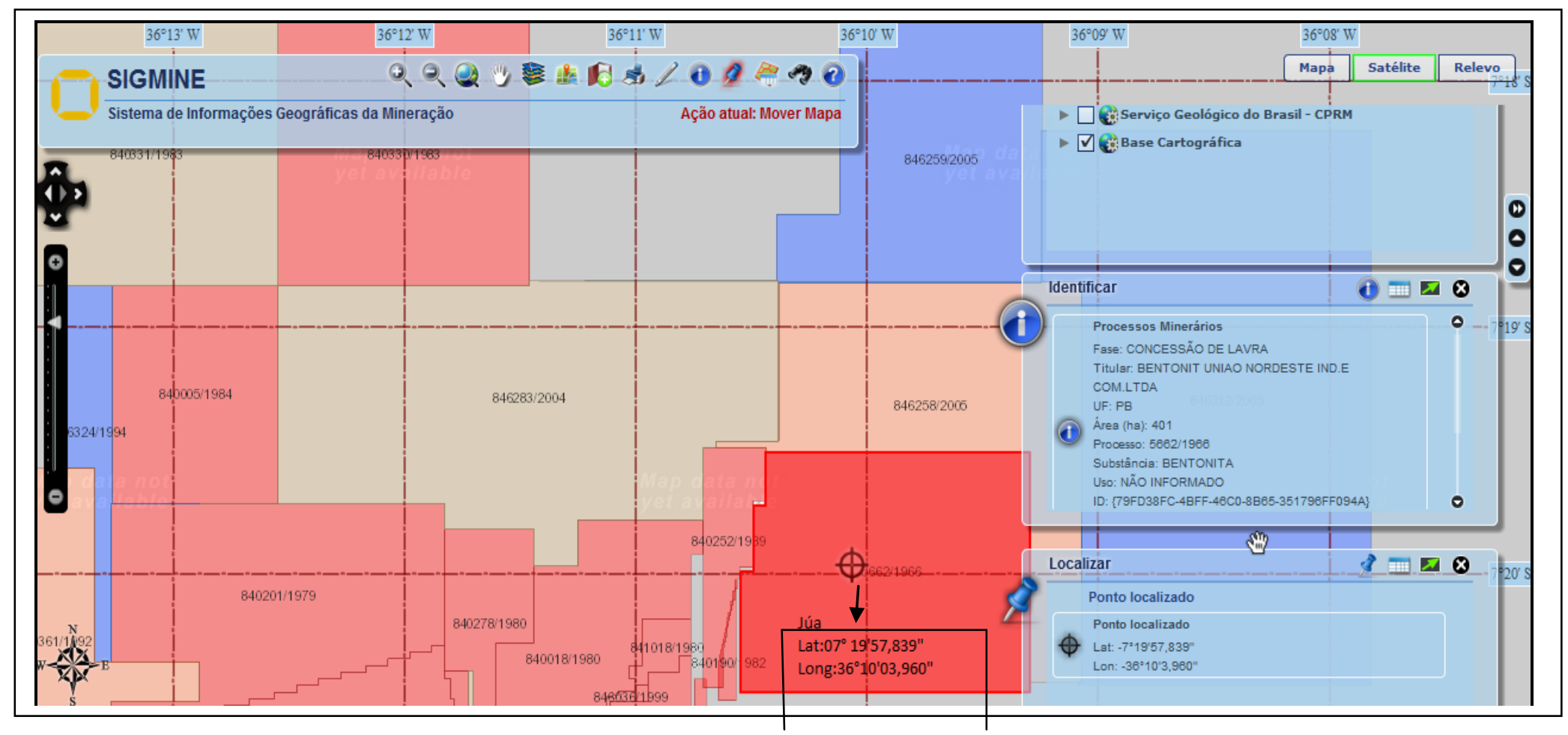

Figura 27: Localização da mina Juá.

Fonte: DNPM, (2011). 


\subsubsection{Bentonitas de Cubati (PB)}

O município de Cubati (figura 28) está localizado na Microrregião Cubati e na Mesorregião Borborema do Estado da Paraíba.

Sua área é de $137 \mathrm{~km}^{2}$, representando $0,2427 \%$ do Estado, 0,0088 \% da Região e $0,0016 \%$ de todo o território brasileiro. $O$ acesso é feito, a partir de João Pessoa, pelas rodovias BR- 230/ PB- 177/ PB -167.

O município foi criado em 1959, a população total é de 6.388 habitantes, sendo 4.030 na área urbana. Cubati está inserida na unidade geoambiental do Planalto da Borborema, formada por maciços e outeiros altos, com altitude variando entre 650 a 1.000 metros. Ocupa uma área de arco que se estende do sul de Alagoas até o Rio Grande do Norte. O relevo é geralmente movimentado, com vales profundos e estreitos dissecados. Com respeito à fertilidade dos solos é bastante variada, com certa predominância de média para alta (CPRM, 2005 b).

O município de Cubati encontra-se inserido nos domínios da bacia hidrográfica do Rio Piranhas, sub-bacia do Rio Seridó. Os principais cursos d' água são os riachos do Feijão, Campo Novo e Cubati. Todos os cursos d'água têm regime de escoamento intermitente e o padrão de drenagem é o dendrítico.

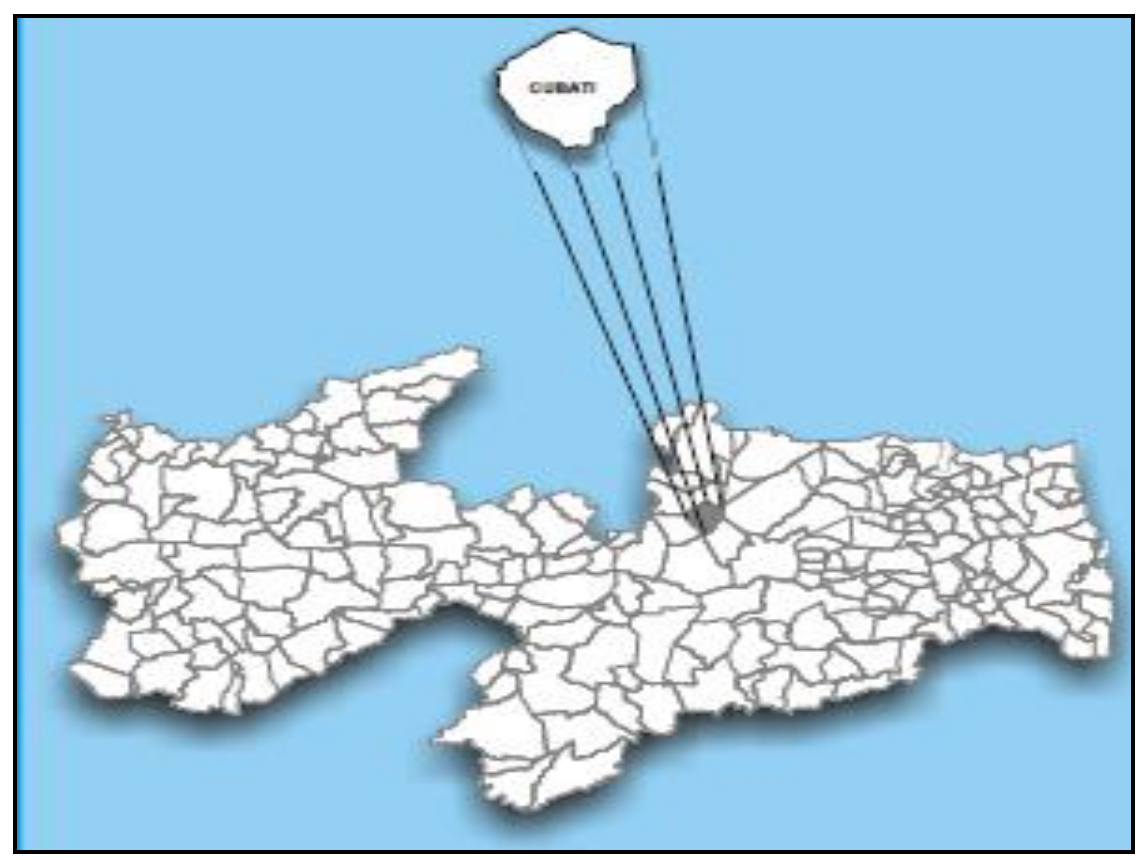

Figura 28: Localização da cidade de Cubati - PB no mapa da Paraíba.

Fonte: CPRM, (2005). 
No município de Cubati, Paraíba, foram descobertos novos jazimentos de bentonitas que podem representar uma interessante alternativa tecnológica que em conjunto com as bentonitas de Boa Vista - PB poderão ampliar as aplicações já existentes. No entanto, esses jazimentos ainda não foram muito estudados e caracterizados. Para a utilização das argilas em processos industriais é importante e indispensável uma identificação completa do tipo de argila e de suas propriedades, para estabelecer quais as combinações de matérias-primas e requisitos de beneficiamento mais adequados para se obter produtos com as propriedades finais desejadas.

Os principais depósitos encontram-se: na Fazenda Campos Novos, Ranulfo, José Telmino, dentre outras. Oito amostras de argilas provenientes desse depósito foram estudadas por Menezes et. al. (2009), onde o mesmo observou que as amostras de Cubati apresentam teores de $\mathrm{MgO}, \mathrm{CaO}$ e $\mathrm{K}_{2} \mathrm{O}$ semelhantes aos observados em bentonitas sul-americanas. As mesmas são constituídas por argilomineral esmectítico, caulinita e quartzo apresentando fração volumétrica de partículas abaixo de $2 \mu \mathrm{m}$, variando de 31 a $41 \%$, e seus constituintes se apresentam em elevado estado de aglomeração.

\subsubsection{Bentonitas de Pedra Lavrada (PB)}

O município de Pedra Lavada (figura 29) situa-se na região centro-norte do Estado da Paraíba, Mesorregião Borborema e Microrregião Seridó Oriental Paraibano, limitando-se com os municípios de Nova Palmeira, Sossego, Cubati, Seridó e com o Estado do Rio Grande do Norte, abrangendo uma área de 391,3 km² (CPRM, 2005 c).

A sede do município tem uma altitude média de $516 \mathrm{~m}$ e apresenta coordenadas $06^{\circ} 45^{\prime} 28^{\prime \prime}$ de latitude sul e $36^{\circ} 28^{\prime} 15^{\prime \prime}$ de longitude oeste, distando da capital cerca de $231 \mathrm{~km}$, sendo seu acesso, a partir de João Pessoa, efetuado através das rodovias pavimentadas BR-130 e PB-177 (CPRM, 2005 c).

O município de Pedra Lavrada foi criado pela Lei número 1.944 de 13 de Janeiro de 1959 e instalado em 25 de Janeiro de 1959. Possui área de $389,6 \mathrm{~km}^{2} \mathrm{e}$ tem população de 6.617 habitantes dos quais 2.446 residem na zona urbana e $4.171(36,9 \%)$ na zona rural. A densidade demográfica é de 17 hab/km² (CPRM, 2005 c). 
LUZ et.al. (2010) relataram em seus trabalhos que recentemente foram descobertos depósitos de bentonita na região de Pedra Lavrada-PB. Este fato gerou uma grande expectativa de ampliação da produção mineral na região. Foram estudadas duas amostras dessas bentonitas, denominadas de Clara e Cinza. As mesmas apresentaram composição mineralógica semelhantes, com predominância de montmorilonita, caulinita e quartzo, secundariamente ocorrem muscovita e ilita. Estudos mais detalhados dessas argilas e das minas da região de Pedra Lavrada estão sendo realizados pelo grupo de pesquisadores do CETEM.

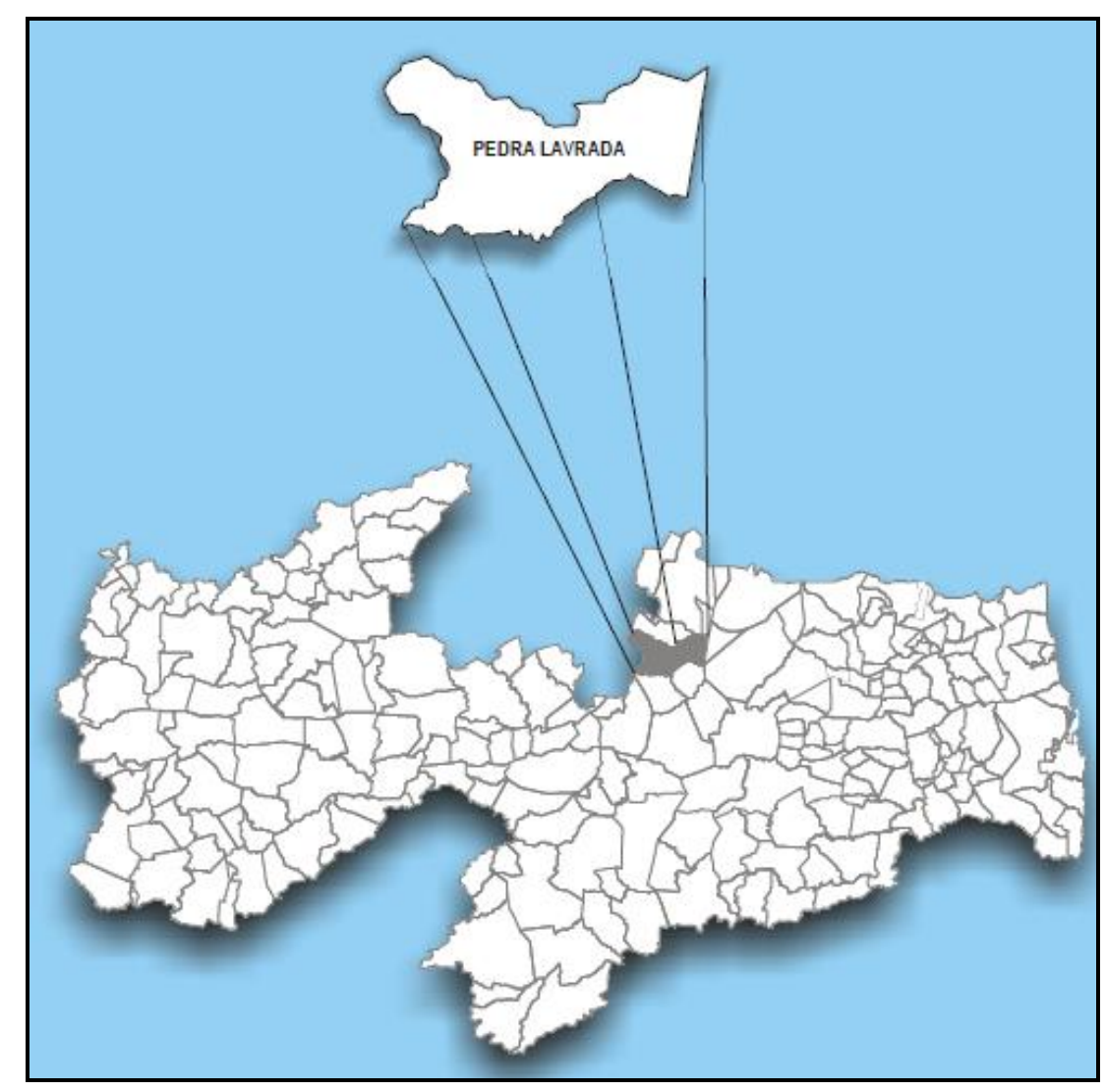

Figura 29: Localização da cidade de Pedra Lavrada -PB no mapa da Paraíba.

Fonte: CPRM, (2005).

\subsubsection{Os Principais Produtores Nacionais}

O parque produtivo nacional é composto por 14 empresas que atuam oficialmente no ramo da mineração no país sendo que $50 \%$ se encontram no Estado da Paraíba (tabela 3). 
Tabela 3: Principais Empresas Produtoras/ Fornecedoras Nacionais.

\begin{tabular}{|c|c|}
\hline EMPRESAS & LOCALIZAÇĀO \\
\hline BENTONISA - Bentonita do Nordeste S/A & Boa Vista - PB \\
\hline BUN - Bentonit União Nordeste & Campina Grande e Boa Vista - PB \\
\hline Aligra Indústria e Comércio de Argilas Ltda. & Taubaté - SP \\
\hline $\begin{array}{c}\text { Argos Extração e Beneficiamento de } \\
\text { Minerais Ltda. }\end{array}$ & Taubaté - SP \\
\hline Bentonita do Paraná Mineração Ltda & Quatro Barras - PR \\
\hline Colorminas - Coloríficio e Mineração Ltda & $\begin{array}{c}\text { Içara - SC, Rio Claro - SP, Criciúma - } \\
\text { SC, Estiva Gerbi - SP, Campo Alegre } \\
\text { - SC, Anápolis - GO e Nossa } \\
\text { Senhora do Socorro - SE }\end{array}$ \\
\hline Companhia Brasileira de Bentonita- CBB & Vitória da Conquimsta - BA \\
\hline DOLOMIL- Dolomita Minérios Ltda & Campina Grande - PB \\
\hline $\begin{array}{l}\text { EBM- Empresa Beneficiadora de Minérios } \\
\qquad \text { Ltda }\end{array}$ & Campina Grande - PB \\
\hline MIBRA Minérios Ltda & Campina Grande - PB \\
\hline MPL- Mineração Pedra Lavrada Ltda & Atibaia - SP \\
\hline Schumacher Insumos para a Indústria & Porto Alegre - RS \\
\hline NERCON & Boa Vista - PB \\
\hline DRESCON S/A - Produtos de Perfuração & Boa Vista - PB \\
\hline
\end{tabular}

Fonte: Silva; Ferreira, (2008).

A Bentonit União Nordeste situada em Boa Vista-PB produziu 48,1\% da bentonita bruta em 2008. Em 2008, três empresas declararam não estar em atividade devido a razões técnico econômicas: João Arruda Construções e Minerações Ltda., União Brasileira de Mineração S/A e Sud Chemie do Brasil Ltda. (Sumário Mineral, 2009).

\subsubsection{Comércio e Preço da Bentonita}

Trabalhos realizados por Coelho (2010), demonstram que o Brasil é autosuficiente em termos de reservas de bentonita, porém, ao se analisar os dados da 
balança comercial de bens primários de bentonita, apresentados na tabela 4, constatou-se que as trocas comerciais brasileiras apresentam um déficit constante.

A bentonita sódica é muito utilizada em função das suas excelentes propriedades coloidais, apresentando grandes aplicações como componentes de lamas de perfurações da indústria de petróleo e gás, para investigações geotécnicas e ambientais e em inúmeros outros usos. O Brasil não possui reservas de bentonita sódica e a produção, por conseguinte, somente pode ser obtida pela ativação da bentonita cálcica (BRAZ, 2002, apud COELHO, 2010).

Tabela 4: Evolução do Saldo da Balança Comercial bens primários de bentonita 2001 a 2008 (US\$ milhões).

\begin{tabular}{lllllllll} 
Substância & $\mathbf{2 0 0 1}$ & $\mathbf{2 0 0 2}$ & $\mathbf{2 0 0 3}$ & $\mathbf{2 0 0 4}$ & $\mathbf{2 0 0 5}$ & $\mathbf{2 0 0 6}$ & $\mathbf{2 0 0 7}$ & $\mathbf{2 0 0 8}$ \\
\hline Bentonita & $-9,3$ & $-9,5$ & $-9,8$ & $-11,2$ & $-13,5$ & $-13,6$ & $-17,9$ & $-17,4$ \\
\hline
\end{tabular}

Fonte: Sumário Mineral modificado, (2000 a 2009).

Os preços da bentonita variam em função da qualidade do produto bruto, da pureza, da função ou aplicação, e do tipo do beneficiamento a que foi submetido o minério. Exemplos de preços de exportação e importação de bens primários de bentonita estão listados na tabela 5 .

Tabela 5: Preços de exportação e bens primários de bentonita - 2001 - 2007 (U\$t).

\begin{tabular}{|c|c|cccccccc} 
Substância & Preços/anos & 2001 & 2002 & 2003 & 2004 & 2005 & 2006 & 2007 \\
\hline \multirow{3}{*}{ Bentonita } & $\begin{array}{c}\text { Preço de } \\
\text { exportação }\end{array}$ & 241 & 361 & 252 & 388 & 369 & 442 & 479 \\
\cline { 2 - 8 } & $\begin{array}{c}\text { Preço de } \\
\text { importação }\end{array}$ & 96 & 82 & 91 & 88 & 75 & 86 & 80 \\
\hline
\end{tabular}

Fonte: Sumário Mineral modificado, (2000 a 2009).

Segundo os dados do Sumário Mineral (2009), as importações de bens primários perfizeram um montante de 215.768 t, no valor de US\$FOB 22.693 milhões, em 2008. As exportações totais de bentonita em 2008 foram de $9.740 \mathrm{t}$, atingindo o montante de US\$-FOB 5.221 milhões (COELHO;CABRAL, 2010). 
Com relação às quantidades importadas e exportadas de bens primários, fica evidente a diferença da quantidade importada em relação à exportada, conforme figura 30 e 31. Observa-se uma curva positiva crescente desde 2002 até 2007. A diferença no ano de 2007, com relação à quantidade importada, chega a 23 vezes o valor da quantidade exportada.

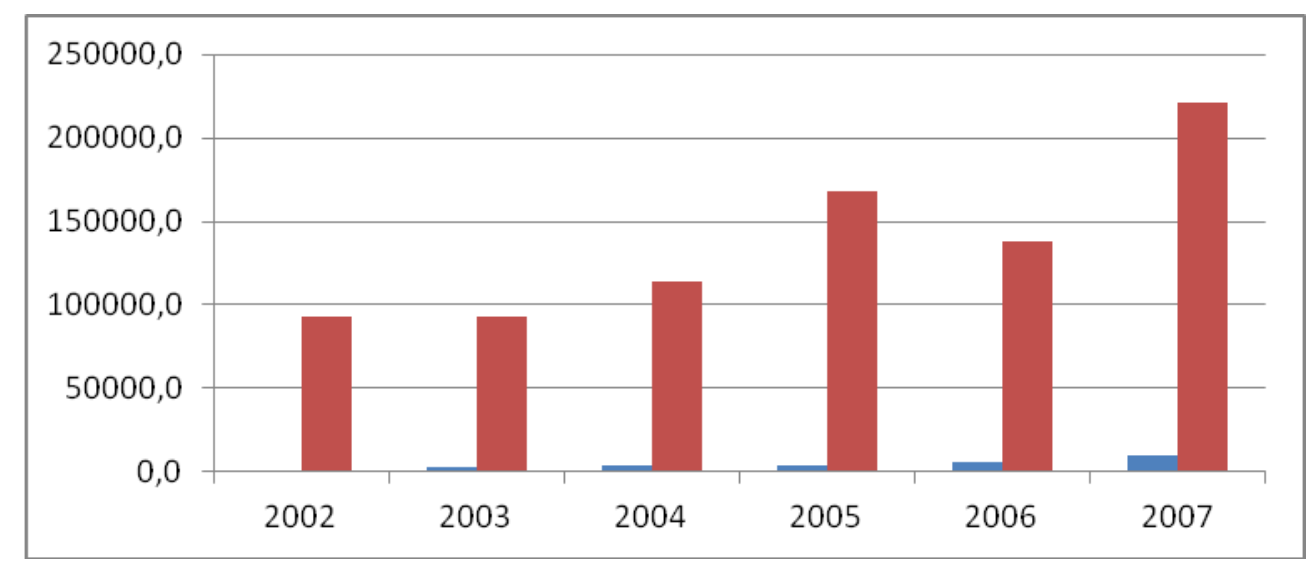

Figura 30: Gráfico ilustrando o comércio de bens primários de bentonita $(\mathrm{t})$ - 20022007;

Fonte: COELHO, (2010).

\begin{tabular}{|c|c|c|c|c|c|c|}
\hline Ano & 2002 & 2003 & 2004 & 2005 & 2006 & 2007 \\
\hline Exportação & 311,0 & 2440,9 & 3388,7 & 4311,2 & 5541,7 & 9450,6 \\
\hline Importação & 92956,2 & 93080,9 & 114138,0 & 168444,0 & 137737,0 & 221069,0 \\
\hline
\end{tabular}

Figura 31: Quadro demonstrando os valores do comércio de bens primários de bentonita (t) de exportação e importação entre 2002-2007.

Fonte: COELHO, (2010).

Os preços de exportação e importação se mantiveram praticamente estáveis nos últimos sete anos (figura 32). O Brasil exporta bentonita com um alto valor, pois o seu custo de produção é elevado em relação aos principais produtores. E importa um minério de alta qualidade, com bom nível de beneficiamento a um preço baixo. 
Os preços médios relativamente elevados das exportações brasileiras estão relacionados a produtos beneficiados (ativação química), evidenciando a qualificação competitiva de parte desse segmento industrial.

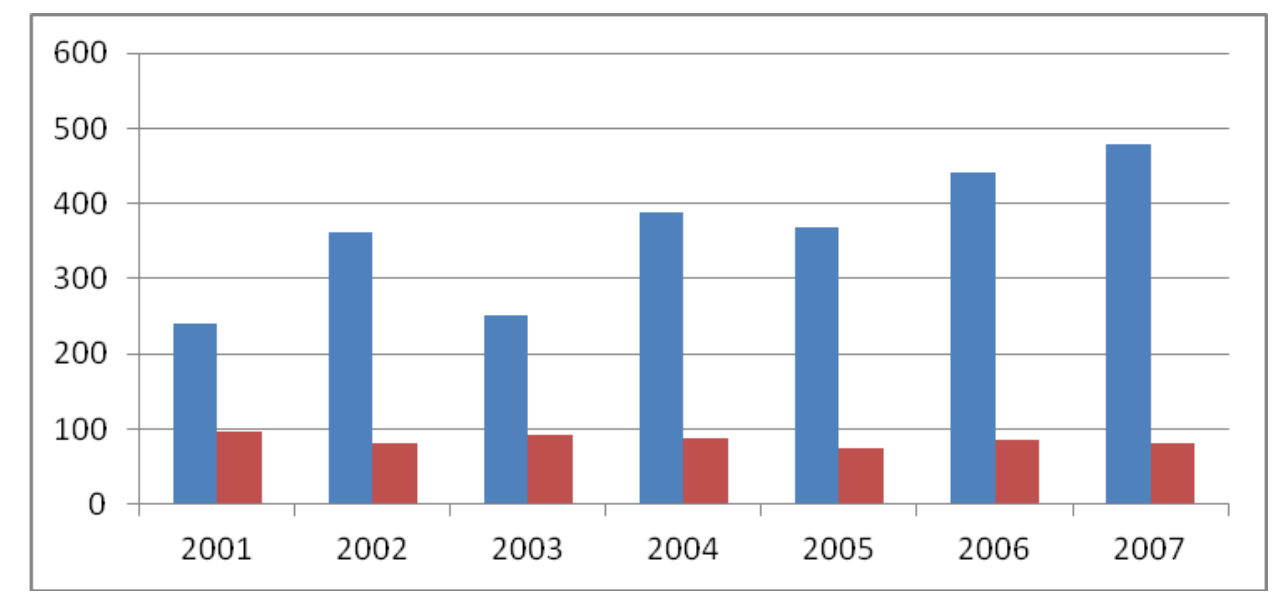

(a)

\begin{tabular}{c|c|c|c|c|c|c|c} 
Ano & 2001 & 2002 & 2003 & 2004 & 2005 & 2006 & 2007 \\
\hline $\begin{array}{c}\text { Preço de } \\
\text { Exportação }\end{array}$ & 241 & 361 & 252 & 388 & 369 & 442 & 479 \\
\hline $\begin{array}{c}\text { Preço de } \\
\text { Importação }\end{array}$ & 96 & 82 & 91 & 88 & 75 & 86 & 80 \\
\hline
\end{tabular}

(b)

Figura 32: (a) Gráfico demonstrando a estabilidade nos preços de bentonitas nos últimos sete anos; (b) Preços de exportação e importação da bentonita (t) - 20022007. Fonte: COELHO, (2010).

Os principais países importadores para os bens primários de bentonita foram: Argentina (49\%), Índia (26 \%) e Grécia (24\%); para os semimanufaturados: EUA (100\%); para os manufaturados: EUA (63\%), Argentina (24\%), China (12\%) (Sumário Mineral - 2009).

Os principais países exportadores para os bens primários de bentonita foram: África do Sul (39,5\%), Argentina (18,9\%), Chile (6,4\%), Venezuela (4,6\%); para os 
manufaturados: Venezuela (89,9\%), Guiné (6,0\%) e Uruguai (2,0\%) (Sumário Mineral - 2009).

Na tabela 6 é apresentado o crescimento do consumo aparente da bentonita beneficiada atingindo 3,4\%.

Tabela 6: Principais estatísticas do consumo aparente da bentonita - Brasil.

\begin{tabular}{|c|c|c|c|c|c|c|}
\hline \multicolumn{3}{|c|}{ Discriminação } & 2005 & $2006^{(r)}$ & $2007^{(r)}$ & $2008^{(p)}$ \\
\hline \multirow[t]{5}{*}{ Produção } & \multicolumn{2}{|l|}{ Bruta (R.O.M.) } & 459.679 & 419.214 & 329.647 & 340.141 \\
\hline & \multicolumn{2}{|l|}{ Comercializada Bruta } & 286.190 & 156.464 & 155.547 & 107.937 \\
\hline & \multicolumn{2}{|l|}{ Beneficiada } & 221.300 & 235.481 & 238.746 & 265.032 \\
\hline & \multicolumn{2}{|l|}{ Comercializada } & 214.543 & 217.553 & 232.708 & 249.488 \\
\hline & \multicolumn{6}{|l|}{ Beneficiada } \\
\hline \multirow[t]{6}{*}{ Importação } & \multirow{2}{*}{$\begin{array}{l}\text { Bens Primários } \\
\text { NCM's } 25081000 \text { e } \\
25082000\end{array}$} & $\mathrm{~T}$ & 170.018 & 139.647 & 221.069 & 215.768 \\
\hline & & $10^{3}$ US\$-FOB & 13.363 & 12.656 & 17.734 & 22.693 \\
\hline & Semimanufaturados & $\mathrm{T}$ & 873 & 2.529 & 3.422 & 3.928 \\
\hline & NCM 38029030 & $10^{3}$ US\$-FOB & 248 & 710 & 1.015 & 1.351 \\
\hline & Manufaturados & $\mathrm{T}$ & 1.649 & 2.190 & 3.274 & 2.269 \\
\hline & NCM 38029020 & $10^{3}$ US\$-FOB & 1.244 & 2.675 & 3.738 & 4.314 \\
\hline \multirow[t]{4}{*}{ Exportação } & Bens Primários & $\mathrm{T}$ & 4.320 & 5.537 & 9.451 & 9.740 \\
\hline & $\begin{array}{l}\text { NCM's } 25081000 \text { e } \\
25082000\end{array}$ & $10^{3}$ US\$-FOB & 1.593 & 2.446 & 4.536 & 5.221 \\
\hline & Manufaturados & $\mathrm{T}$ & 54 & 24 & 61 & 1.896 \\
\hline & NCM 38029020 & $10^{3}$ US\$-FOB & 89 & 8 & 30 & 329 \\
\hline \multirow{3}{*}{$\begin{array}{l}\text { Consumo } \\
\text { Aparente }^{(1)}\end{array}$} & Bruta & $\mathrm{T}$ & 451.888 & 290.574 & 541.265 & 313.966 \\
\hline & & & & & & \\
\hline & Beneficiada & $\mathrm{T}$ & 217.011 & 222.248 & 245.381 & 253.790 \\
\hline \multirow{3}{*}{$\begin{array}{l}\text { Preços } \\
\text { Médios }^{(2)}\end{array}$} & In natura & $\mathrm{R} \$ / \mathrm{t}$ & 14,09 & 15,65 & 14,5 & 25,28 \\
\hline & Moída Seca & $\mathrm{R} \$ / \mathrm{t}$ & 240,71 & 237,43 & 235 & 266,57 \\
\hline & Ativada & $\mathrm{R} \$ / \mathrm{t}$ & 348,77 & 369,85 & 232 & 382,70 \\
\hline
\end{tabular}

Fonte: DNPM, (2009). (1) Produção comercializada + Importação - Exportação. (2) Preço médio nominal informado pelas empresas; (p) Preliminar, (r) Revisado; (R.O.M.) - Run of Mine; (NCM) Nomenclatura comum do MERCOSUL. 
Na tabela 7 estão listados os preços médios nacionais informados pelas empresas, constantes do Sumário Mineral, do período de 2004 a 2008.

Tabela 7: Preços nacionais de bentonita.

\begin{tabular}{|c|c|c|c|c|c|c|c|}
\hline \multicolumn{3}{|c|}{ Discriminação } & 2004 & 2005 & 2006 & 2007 & 2008 \\
\hline \multirow{3}{*}{$\begin{array}{l}\text { Preços } \\
\text { Médios }^{(1)}\end{array}$} & $\begin{array}{c}\text { In } \\
\text { Natura }\end{array}$ & $\mathrm{R} \$ / \mathrm{t}$ & 9,68 & 14,09 & 15,65 & 14,50 & 25,28 \\
\hline & $\begin{array}{c}\text { Moída } \\
\text { Seca }\end{array}$ & $\mathrm{R} \$ / \mathrm{t}$ & 209,58 & 240,71 & 237,43 & 235,00 & 266,57 \\
\hline & Ativada & $\mathrm{R} \$ / \mathrm{t}$ & 288,42 & 348,77 & 369,85 & 232,00 & 382,70 \\
\hline
\end{tabular}

Fonte: Sumário Mineral, (2009). Obs.(1) Preço médio nominal informado pelas empresas.

Na tabela 8 estão listados os preços médios internacionais informados pela revista Industrial Minerals.

Tabela 8: Preços Internacionais de bentonita (t).

\begin{tabular}{rcc}
\hline \multicolumn{1}{c}{ Local } & Tipo de Bentonita & Preço \\
\hline Portos Europeus & Grau Cat litter 1-5mm & $€ 50-70$ \\
\hline Índia FOB Kandla & Grau Cat litter & $\$ 36-38$ \\
Índia & OCMA/API grade & $\$ 43-53$ \\
Wyoming/EUA & Grau API & $\$ 70-100$ \\
Wyoming/EUA & Bruta & $\$ 44-100$ \\
Wyoming/EUA & Fundição & $\$ 70-90$ \\
\hline
\end{tabular}

Fonte: Industrial Minerals, (2010). 


\subsubsection{Bentonitas, Perspectivas no Mercado}

No mercado mundial atual, o segmento de pet litter corresponde ao maior consumidor final de bentonitas, alcançando 4,5 Mt em 2007. No entanto, o ramo de fundição deverá ultrapassá-lo já em 2012, devido ao aumento da demanda de bentonita na pelotização de minério de ferro. Este fato deve-se, principalmente, à grande expansão do consumo chinês. A tendência é que em 2012 ocorra um adicional de 45,3 Mt no montante do consumo anual, resultante do aumento da capacidade de pelotização de minério de ferro já programada para o futuro recente (COELHO;CABRAL, 2010).

A procura de bentonita para lamas de perfuração tende a ampliar cerca de 2 $\%$ por ano até 2012. O consumo está intimamente associado à atividade de perfuração, que, por sua vez, está ligada ao mercado de petróleo/gás, sendo que os preços dessas commodities vêm se elevando paulatinamente.

Fora estas utilizações principais, elevadas taxas de crescimento são esperados em outros mercados especializados. A indústria de óleos comestíveis, e em particular as do óleo de palma, apresentou um aumento médio de 8,2 \% ao ano no período 1997 a 2006, atingindo a produção recorde de 37,3 Mt em 2006. Grande quantidade de óleos comestíveis é vendida em bruto, especialmente na Ásia, havendo um potencial significativo para a expansão da utilização desse insumo no processo de clareamento na região (ROSKILL, 2010 apud COELHO;CABRAL, 2010).

Atualmente, a capacidade brasileira de produção de pelotas é cerca de 56,0 $\mathrm{Mt} / \mathrm{ano}$. Com os projetos previstos esta capacidade atingirá $70 \mathrm{Mt} / \mathrm{ano}$ em 2013. Esta elevação implicará na ampliação da demanda de bentonita que deverá ser atendida em grande parte pela importação, devido, principalmente, às características das reservas nacionais que, em geral, apresentam baixa qualidade para essa finalidade.

O Brasil precisa incrementar os investimentos em pesquisa mineral e tecnológica a fim de buscar a ampliação de reservas e a melhoria da qualidade dos produtos a base de bentonita, para evitar que o seu mercado seja dominado por importações oriundas da Argentina, dos Estados Unidos e Índia (COELHO;CABRAL, 2010).

Nos últimos cinco anos, vêm ocorrendo um aumento no consumo de bentonita no Brasil, relacionado ao crescimento do país (aumento do PIB e da 
produção de produtos para exportação). O consumo aparente de bentonita beneficiada mantém-se no intervalo entre 200 e 250 mil toneladas por ano (COELHO;CABRAL,2010).

A tabela 9 indica a projeção do consumo de bentonita de 2010 a 2030, a partir de estudos que considerou três cenários para o crescimento da economia brasileira: Cenário 1 - Frágil (2,3\% a.a); Cenário 2- Vigoroso (4,6\% a.a); e Cenário 3- Inovador $(6,9 \%$ a.a) (COELHO,2010).

Tabela 9: Projeção do consumo de bentonita (t).

\begin{tabular}{cccc} 
Anos & $\begin{array}{c}\text { Cenário 1- } \\
\text { Frágil }\end{array}$ & $\begin{array}{c}\text { Cenário 2- } \\
\text { Vigoroso }\end{array}$ & $\begin{array}{c}\text { Cenário 3- } \\
\text { Inovador }\end{array}$ \\
\hline 2010 & 298.903 & 301.163 & 303.040 \\
2015 & 323.137 & 332.404 & 340.245 \\
2020 & 339.030 & 359.987 & 379.807 \\
2030 & 365.347 & 429.086 & 499.334 \\
\hline
\end{tabular}

Fonte: COELHO;CABRAL, (2010).

Esta pressão de demanda certamente deverá fomentar a mineração nacional. No entanto, alguns dos fatores que poderão inibir o aumento da produção nacional estão relacionados à concorrência das importações de bentonitas da Argentina e Índia, que apresentam melhor qualidade e menores preços, respectivamente; a carência de investimentos em pesquisa mineral no país; e a utilização dos minerais ou materiais substitutos da bentonita.

A Figura 33 apresenta a projeção de consumo de bentonita de 2010 a 2030 nos três cenários: Frágil, Moderado e Inovador.

Observa-se que a tendência de elevação do consumo se mantém de maneira constante, praticamente independente do PIB. Isto reflete a expectativa de expansão dos dois grandes setores consumidores, indústria petrolífera e siderúrgica, que apresentam perspectivas de crescimento, para os próximos 20 anos, de maneira contínua e consistente; face, principalmente, ao pré-sal e a expansão da indústria siderúrgica no país. 


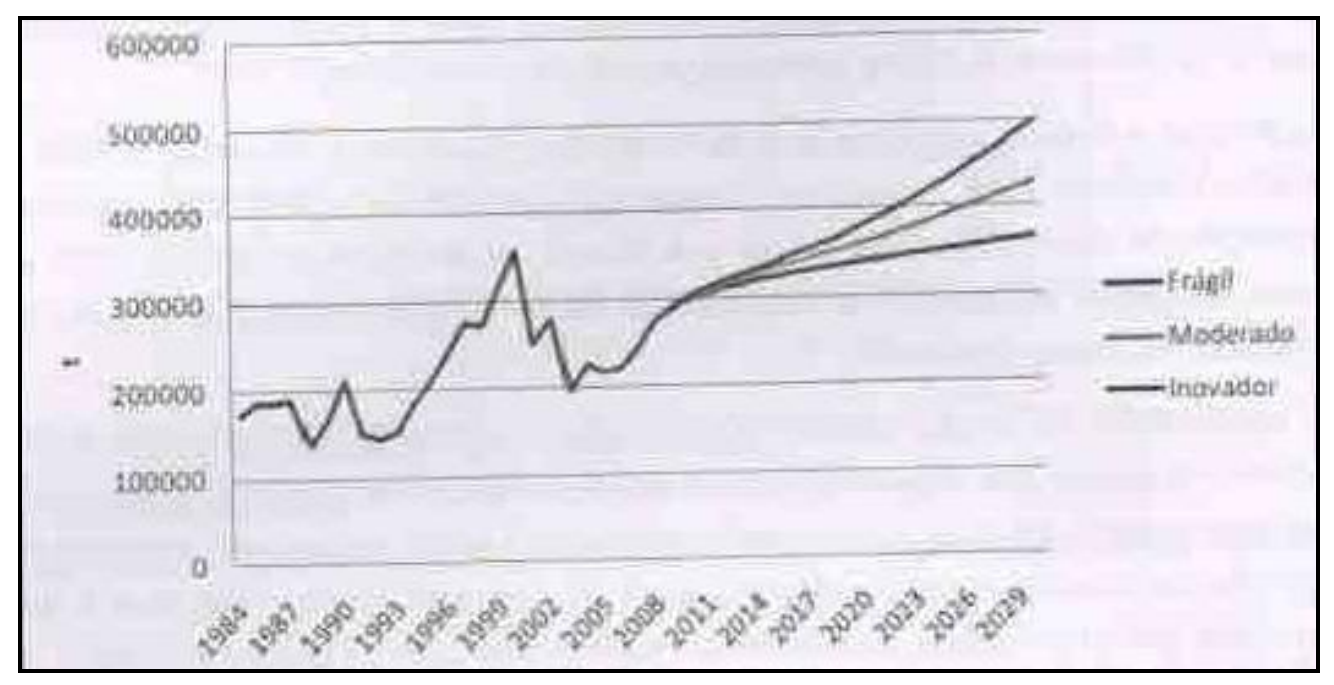

Figura 33: Projeções da demanda 2010/2030 nos três cenários. Fonte: COELHO;CABRAL, (2010).

A tabela 10 apresenta uma projeção da produção brasileira - 2010-2030.

Tabela 10: Projeção da produção brasileira - 2010 a 2030.

\begin{tabular}{|l|l|}
\hline Ano & Toneladas \\
\hline 2010 & 246.952 \\
2015 & 272.655 \\
2020 & 301.033 \\
2025 & 332.364 \\
2030 & 366.957 \\
\hline
\end{tabular}

Fonte: COELHO;CABRAL, (2010).

\subsubsection{Principais Usos das Bentonitas}

As bentonitas possuem diversas aplicações industriais (BERGAYA;THENG;LAGALY, 2006) em aproximadamente 18 segmentos industriais. Dentre elas podemos citar 71 aplicações na tabela 11: 
Tabela 11: Principais Aplicações Industriais da Bentonita.

\section{SEGMENTO INDUSTRIAL}

1-INDÚSTRIA DA

FUNDIÇÃO

1)Bentonita como ligante de areias para fundição de aço e ferrosos;

\section{APLICAÇÃO}

2-INDÚSTRIA DE MINÉRIO DE FERRO

\section{3-INDÚSTRIA DE PETRÓLEO}

2)Bentonita como ligante para pelotização de minério de ferro;
3) Bentonita nos fluidos de perfuração on-shore;
4) Bentonita nos fluidos de perfuração off-shore;
5) Bentonita nos fluidos para perfuração direcional;
6) Bentonita como agente catalítico de craqueamento;

\section{4-INDÚSTRIA DA CONSTRUÇÃO CIVIL}

7) Bentonita para perfuração de poços artesianos;

8) Bentonita para impermeabilização de solos;

9) Bentonita para impermeabilização de barragens, canais e túneis para metrôs;

10) Bentonita para impermeabilização de túneis para metrôs;

11) Bentonita para concretos e argamassas;

12) Bentonita para isolamento de lagoas e açudes;

13) Bentonita para fundações, estanqueamentos e paredes de diafragma;

14) Bentonita para aterramento elétrico;

\section{5-INDÚSTRIA DE BEBIDAS E ALIMENTOS}

15) Bentonita para clarificação de vinhos;

16) Bentonita para clarificação de sucos;

18) Bentonita para clarificação de cervejas;

19) Bentonita para clarificação de caldo de cana-de-açúcar;

20) Bentonita como agente filtrante de óleos, sucos e vinhos;

21) Bentonita para complemento alimentar;

22) Bentonita como agente desproteinizante;
6-INDÚSTRIA DE REFINO E ÓLEOS
23) Bentonita na clarificação de óleos vegetais;

24) Bentonita na clarificação de óleos minerais;

25) Bentonita na clarificação de óleos de origem animal;

26) Bentonita na clarificação de gorduras e sebos;

27)Bentonitas na reciclagem de óleos usados em motores à explosão; 
7-INDÚSTRIA DE SABÃO

28)Bentonita como carga para sabão;

29)Bentonitas na fabricação de produtos de limpeza;

8-INDÚSTRIA DE TINTAS 30) Bentonita para tintas base água;

31) Bentonita para tintas base óleo;

32) Bentonita como agentes anti-sedimentante para tintas;

33) Bentonita como espessador de adesivos, esmaltes e vernizes;

9-INDÚSTRIA

VETERINÁRIA
34) Bentonita para aditivo de ração animal;

35) Bentonita para areia sanitária para animais de estimação;

36) Bentonita como adsorventes de toxinas

(micotoxinas/aflotoxinas);
10-INDÚSTRIA DE

BORRACHAS E

PLÁSTICOS
37) Bentonita como cargas tecnológicas;

38) Bentonita como cargas reforçantes;

39) Bentonita como cargas tecnológicas e inertes;

40) Bentonita nos nanocompósitos;

\section{1-INDÚSTRIA}

COSMÉTICA
41) Bentonita para mascáras;

42) Bentonita para shampoo;

43) Bentonita para sabonetes;

44) Bentonita para condicionadores;

45) Bentonita para batons;

46) Bentonita para hidratantes;

47) Bentonita para cremes;

48) Bentonita para esfoliantes;

49) Bentonita para maquiagens;

50) Bentonita com ação antidermatosa;

12-INDÚSTRIA DE PAPEL 51) Bentonita como cargas para papel;

52) Bentonita como cargas para papelão;

53) Bentonita como agente de descoloração de papel reciclado;

\section{3-INDÚSTRIA FARMACÊUTICA}

54) Bentonita como carga ativa e inerte;

55) Bentonita para comprimidos;

56) Bentonita como bactericidas;

57) Bentonita como bacteriostática;

58) Bentonita como cicatrizante;

59) Bentonita em massas para eletrodos em eletroencefalograma; 
14-INDÚSTRIA DO MEIO AMBIENTE
60) Bentonita para tratamento de efluentes;

61) Bentonita para remoção de metais pesados;

62) Bentonita investigações geotécnicas e ambientais;

63) Bentonita para impermeabilização de aterro sanitário;
15-INDÚSTRIA DE ROCHAS ORNAMENTAIS

16-INDÚSTRIA CERÂMICA
64) Bentonita para serragem do granito;

65) Bentonita para tijolos;

66) Bentonita para cerâmicas e lousas sanitárias;

67)Cerâmicas de uso elétrico e isolante;

17-INDÚSTRIA DE COMBUSTÍVEIS
68) Bentonita na catálise;

69) Bentonita na clarificação de biodiesel;

70) Bentonita na desidratação do etanol;

\section{8-INDÚSTRIA DE PRODUTOS HIGIÊNICOS E SANITÁRIOS}

71) Bentonita como diluentes para inseticidas e pesticidas.

\subsubsection{Propriedades das Argilas para Aplicação Industrial}

Algumas propriedades das argilas estão diretamente relacionadas com suas aplicações, e segundo Abreu (1973) são elas:

Granulometria: é uma das características mais importantes dos argilominerais porque ela domina muitas de suas propriedades, pois a argila é finamente dividida e desagrega-se facilmente (MEIRA, 2001).

Superfície específica: As argilas possuem elevada superfície específica muito importante em certos usos industriais em que a interação sólido-fluído dependem diretamente da superfície específica do sólido: cerâmica, catálise e branqueamento de óleos. A superfície específica de uma argila é definida como a área da superfície externa mais a área da superfície interna das partículas constituintes, expressa em $\mathrm{m}^{2} / \mathrm{g}$. A superfície específica exprime o teor em fração argilosa ou o teor relativo de finos, médios e grossos bem como o grau de dispersão/agregação das partículas constituintes de argila (MEIRA, 2001). 
Tamanho das partículas: as argilas são constituídas por partículas fracamente agregadas, que se dispersam na água permitindo a separação das partículas maiores (que sedimentam) das menores (que se mantêm em suspensão coloidal).

Plasticidade: é a propriedade que têm as argilas, quando molhadas, de se deixarem moldar conservando as formas que the são dadas. Também pode ser definida como sendo uma propriedade que se manifesta na mudança de forma sem rotura de uma massa feita com argila e água por aplicação de uma força exterior e pela retenção da forma quando a força é removida ou reduzida abaixo de um certo valor, corresponde à chamada tensão de cedência. $O$ termo trabalhabilidade usa-se também, por vezes, como sinônimo de plasticidade (MEIRA, 2001).

Retração: a argila contrai-se pela secagem em função da perda de água e consequentemente aproximação das partículas. $O$ índice de contração varia com a natureza das argilas; as de partículas mais finas sofrem maior contração.

Refratariedade: propriedade na qual a estrutura não é modificada quando submetida a altas temperaturas. $O$ ponto de fusão das argilas depende da sua constituição química. As argilas de alto ponto de fusão são chamadas refratárias e correspondem às de natureza caulínica; as montmorilonitas e as ilitas têm menor ponto de fusão.

Viscosidade: A viscosidade de um fluido traduz a resistência que ele oferece à fluência. É a medida de fricção interna de suas moléculas. A viscosidade de qualquer suspensão de argila sofre modificações geralmente aumentando continuamente e irreversivelmente com o tempo.

Tixotropia: as argilas coloidais dispersas na água, numa adequada concentração, adquirem o estado de gel, solidificando-se quando ficam em repouso; se sofrerem uma agitação, passam novamente ao estado de sol. Esse fenômeno está relacionado com as argilas de partículas extremamente finas do grupo das esmectitas e tem grande importância prática no preparo de lamas para uso em perfuração de poços de petróleo, destinadas a prevenir desabamentos das paredes do poço em perfuração e a conduzir os detritos de rochas para fora do poço e, ainda, para mantê-los em suspensão quando ocorrer uma paralisação da sondagem (SOUZA SANTOS, 1975). 


\subsubsection{Processo de Modificação de Argilas}

A modificação química das argilas permite 0 ajuste de suas propriedades físico-químicas, agregando funcionalidades aos materiais para uso em diversos tipos de aplicações tecnológicas (COELHO et al., 2007).

Quando a modificação é feita apenas na superfície dos grãos, as argilas têm aplicações nas quais é adicionada como carga micrométrica na composição de materiais (BURMEISTER, 1997).

A possibilidade de modificação química das argilas permite 0 desenvolvimento do seu uso, agregando valor a esse abundante recurso natural. As argilas modificadas são usadas em diversas aplicações tecnológicas, como por exemplo: fluidos de perfuração base de óleo, nanocompósitos polímero-argila, agroquímicos, detergentes, fármacos, cosméticos e catalisadores. Existem vários tipos de modificações na estrutura química da argila, tais como, organofilização das argilas, pilarização, ativação ácida e processos de intercalação.

\subsubsection{Organofilização}

As argilas organofílicas são obtidas pela troca iônica dos cátions interlamelares de argilas catiônicas por cátions orgânicos, principalmente tensoativos quaternários de amônio (figura 34). Dessa forma, a superfície das lamelas individuais de argila torna-se hidrofóbica. A hidrofobização das lamelas também pode ser obtida pela adsorção de tensoativos não-iônicos etoxilados sobre suas superfícies, via interação eletrostática com os cátions interlamelares (FERREIRA, 2005). 


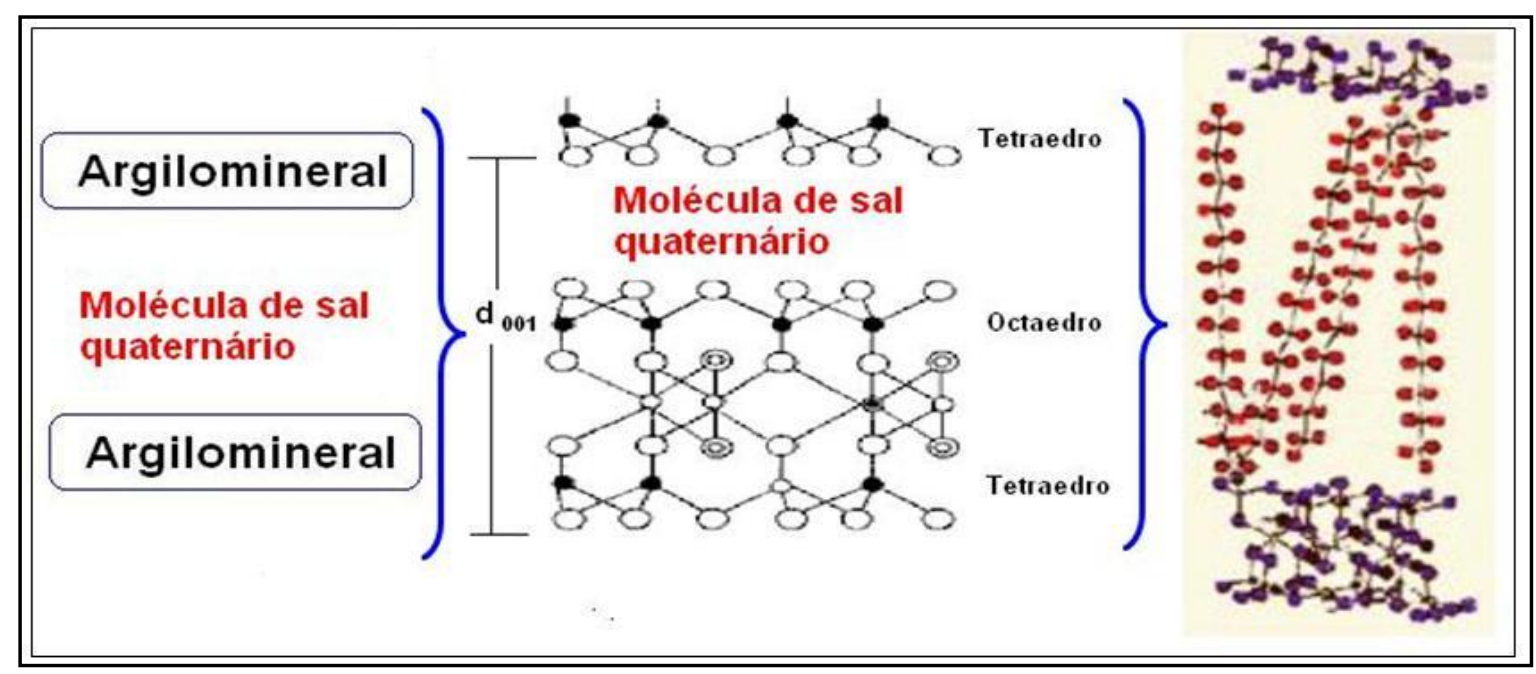

Figura 34: Bentonitas que incham em água são transformadas em organofílicas por meio de reações de troca catiônica com sais quaternários de amônio.

Fonte: Adaptado de Silva, 2005.

As argilas organofílicas são matérias-primas de elevado valor agregado para uma série de aplicações industriais. A maior parte da argila organofílica adquirida no mercado nacional é importada. Sua produção industrial é pequena no Brasil, contando com a atuação de poucas empresas, como a Spectrochem Ind. e Com. de Aditivos Ltda., de Santa Catarina, que atualmente fornece argilas organofílicas para os mercados de tintas, graxas e resinas de poliéster. Assim, o desenvolvimento tecnológico da fabricação de argilas organofílicas (FERREIRA et al., 2008) em escala industrial é economicamente interessante para o Brasil. Processos e tensoativos alternativos para a fabricação de argilas organofílicas estão protegidos por patentes no Brasil (NETO et al., 1982).

Os protocolos de organofilização descritos na literatura científica geralmente envolvem a preparação de suspensões aquosas de argila, com concentrações entre 3 e 10\% em massa, e a posterior adição de soluções de tensoativos quaternários de amônio à suspensão (figura 35). A argila organofílica assim obtida forma uma torta úmida, que é separada por filtração, seca em estufa e moída. Esse modelo de protocolo, apesar de possibilitar a obtenção de argilas organofílicas de excelente qualidade, não é economicamente viável em escala industrial devido ao custo muito elevado envolvido no processo de secagem da torta úmida. Dessa forma, o desenvolvimento tecnológico de protocolos de organofilização de argilas que 
eliminem a etapa de dispersão da argila in natura em água é essencial para a diminuição dos custos de produção desse importante insumo industrial.

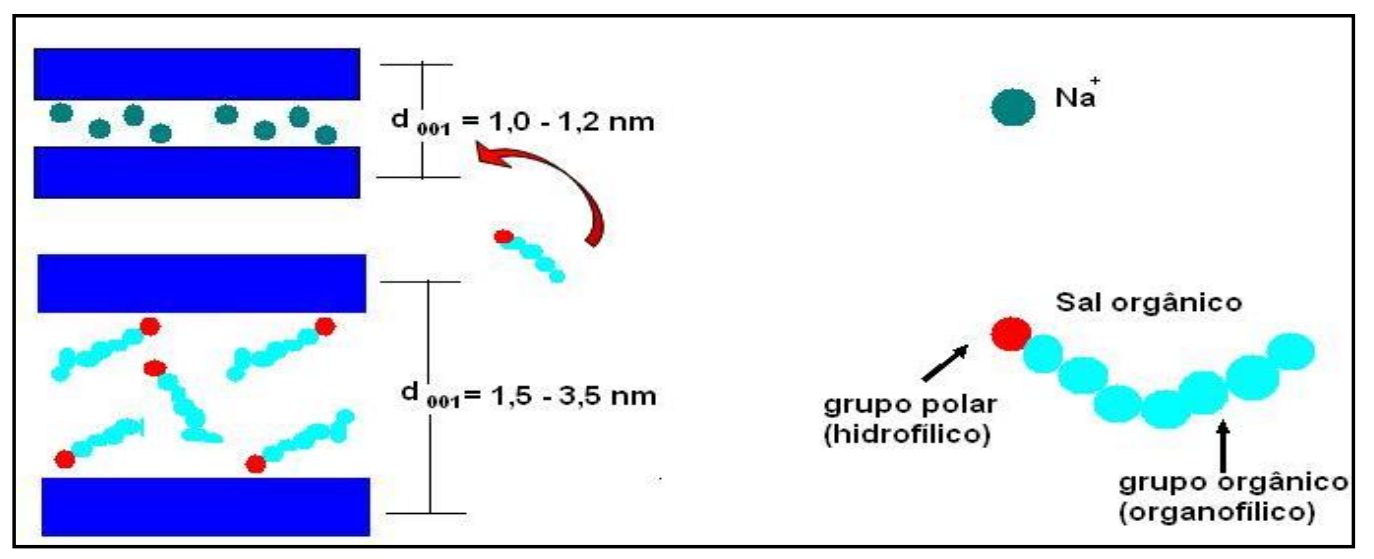

Figura 35: Esquema da introdução do sal orgânico e da substituição dos cátions trocáveis das argilas por estes sais.

Fonte: Adaptada de Barbosa, 2005.

\subsubsection{Pilarização}

O processo conhecido como pilarização de argilas é um método bastante usado em catálise heterogênea (KLOPROGGE et al., 1999). É necessário que o material de partida seja uma bentonita, que possui propriedades de inchamento e troca iônica, essenciais para esse processo. Argilas pilarizadas são materiais com estruturas abertas e rígidas obtidas pela intercalação de espécies volumosas nos espaços interlamelares.

A figura abaixo, mostra esquematicamente uma argila 2:1 pilarizada (figura 36). Entre as camadas separadas a uma distância $D_{001}$. O espaçamento basal, $d_{001}$, é a distância entre as bases de camadas separadas pelos pilares. Estes pilares são grandes cátions que foram introduzidos na argila por troca catiônica com os cátions interlamelares naturais da argila. Os cátions interlamelares naturais da argila que não são trocados continuam no espaço interlamelar $(B)$ e estão representados na figura como cátions trocáveis residuais ( $\square$. Os pilares possuem grupos funcionais (•) que Ihes podem dar certas propriedades catalíticas; os pilares estão separados uns dos outros por uma distância interpilar (E). 


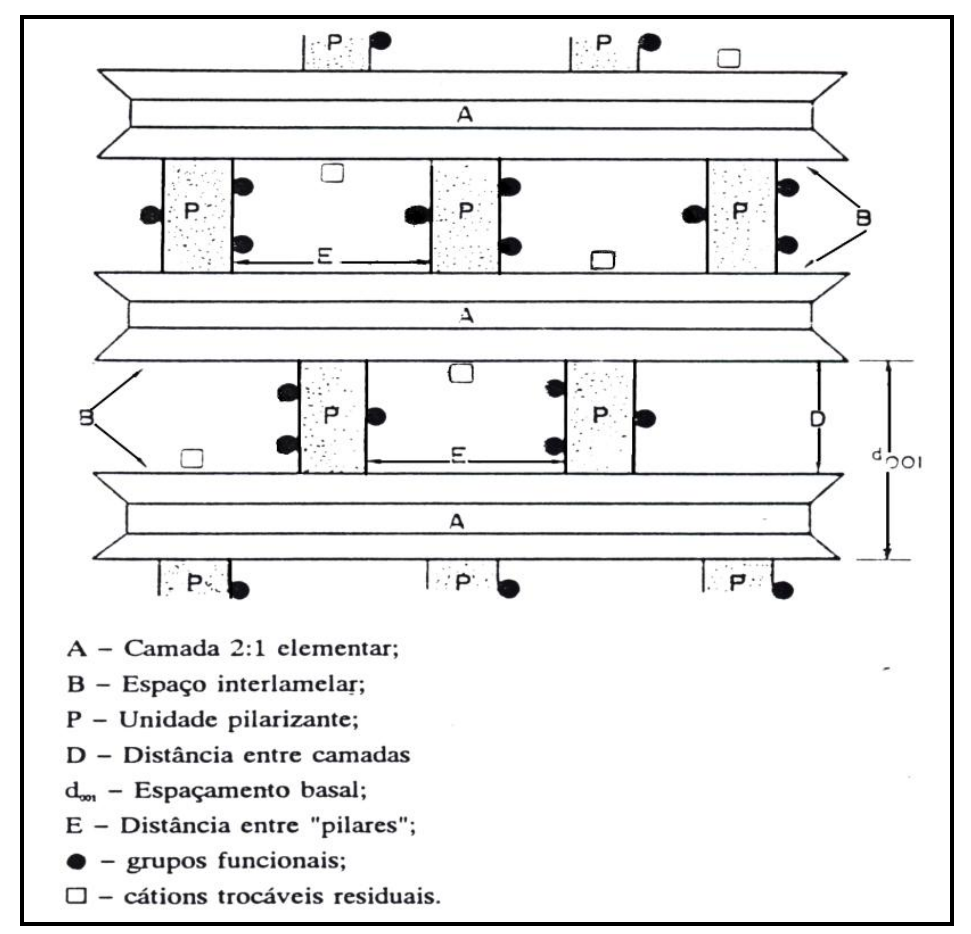

Figura 36: Esquema de uma argila 2:1 expansível pilarizada.

Fonte: Souza Santos e Viera Coelho, 1988b

As argilas pilarizadas resultam da calcinação das argilas intercaladas em uma temperatura estabelecida conforme representação esquemática na figura 37.

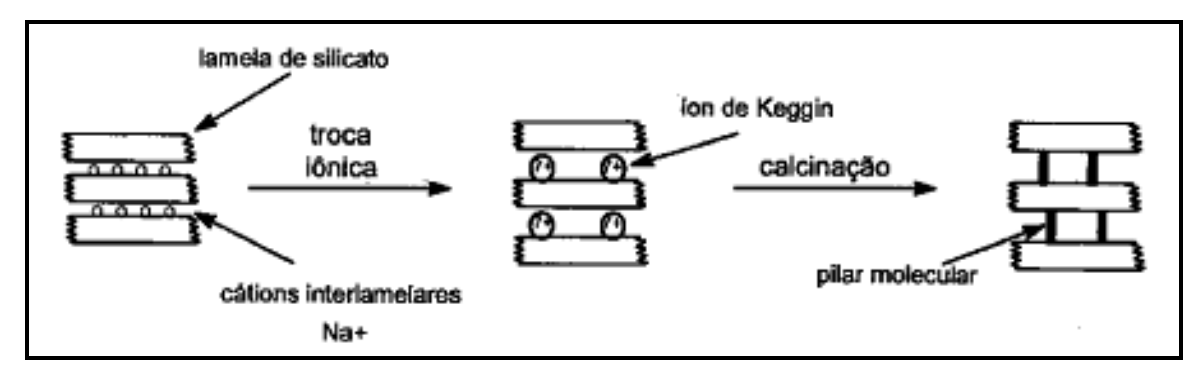

Figura 37: Representação esquemática do processo de pilarização.

Fonte: LUNA et al., 1999.

Elas possuem geralmente altas áreas superficiais (50 a $200 \mathrm{~m}^{2} / \mathrm{g}$ ), grandes volumes de poro e tamanhos de poro ajustáveis, além de fornecerem acidez superficial forte e pilares de óxidos metálicos cataliticamente ativos. As argilas pilarizadas são catalisadores hidrotermicamente menos estáveis que as zeólitas, mas podem possuir poros maiores, favorecendo reações de moléculas mais volumosas (KLOPROGGE et al., 1999). 
O processo de preparação de uma argila pilarizada está resumido nos seguintes passos: inchamento da esmectita com água; troca dos cátions interlamelares por complexos metálicos oligoméricos ou poliméricos parcialmente hidratados; secagem e calcinação para transformação dos precursores polioxocátions em pilares de óxido metálico. Nessa última etapa os pilares óxidos se ligam covalentemente às folhas tetraédricas da argila, mantendo-as separadas permanentemente. Os polioxocátions, que também podem ser chamados de agentes pilarizantes, são comumente constituídos por complexos de metais como alumínio, cromo, ferro, titânio e zircônio (KLOPROGGE et al., 1999). Os pilares podem ser constituídos por uma única espécie de óxido metálico ou por combinação de dois ou mais óxidos.

\subsubsection{Ativação Ácida}

A ativação ácida é o método usual empregado para modificar as características texturais de argilominerais. Os tratamentos de ativação por meio de ácidos inorgânicos aumentam a área específica da argila devido à desorganização da estrutura, pela eliminação de diversas impurezas minerais e pela criação de mesoporos. Além disto, substituem os cátions alcalinos e/ou alcalino-terrosos, presentes na estrutura cristalina ou como cátions intercalados trocáveis, por cátions $\mathrm{H}_{3} \mathrm{O}^{+}$. Desta forma, os tratamentos ácidos têm sido usados para obtenção de sólidos com sítios ácidos e com maior porosidade, propriedades estas que têm influência na aplicação desses materiais como catalisadores ácidos. De acordo com Vaccari (1998), a condição ótima de tratamento varia de argilomineral para argilomineral, em função da composição química, nível de hidratação e, principalmente, da natureza dos cátions trocáveis (VACCARI, 1999).

A maioria dos trabalhos encontrados na literatura utiliza bentonita ativada com ácido clorídrico ou sulfúrico. As variáveis envolvidas no tratamento geralmente são:
a) tipo e concentração do ácido usado;
b) tempo e temperatura de tratamento;
c) tempo e temperatura de secagem. 
No entanto não são muitos os estudos publicados comparando os efeitos destas variáveis no tratamento ácido deste argilomineral (PERMIEN et al., 1995).

As propriedades estruturais das argilas naturais são modificadas pelos métodos de ativação ácida, produzindo materiais com áreas superficiais maiores, maior acidez e porosidade, além de boa estabilidade térmica (RODRIGUES et al., 2006).

As argilas ativadas com ácidos são utilizadas principalmente em processos de clarificação ou purificação de óleos, graxas e gorduras animais, vegetais e minerais (VALENZUELA-DIAZ \& SOUZA SANTOS,2001).

\subsubsection{Suporte catalítico}

Os catalisadores suportados consistem de uma fase ativa e uma fase inerte ao processo catalítico, sendo a última um material quimicamente e termicamente estável, como a alumina. Este suporte, ou fase inerte, permite que a fase ativa exista como nanopartículas que são resistentes à sinterização (ANJOS et al., 2004). processamento de catalisadores suportados em superfícies ativas pode levar frequentemente, ao surgimento de diferentes tipos de reações químicas decorrentes das interações entre os sítios ativos e o suporte do catalisador.

A quantidade relativa dos sítios de Brønsted ou Lewis e suas características ácido/base estão relacionadas com a natureza dos óxidos e grau de hidratação superficial. A superfície de óxidos inorgânicos pode, conseqüentemente, ser representada como um ligante multidentado. Este dualismo da superfície reativa pode ser interpretado como inerente a elevada atividade, reconhecido como uma característica determinante nas propriedades de um suporte catalítico. Suportes catalíticos à base de óxidos de zircônio, titânio, cério, alumínio, silício, nióbio e zinco entre outros, são freqüentemente usados na síntese do biodiesel. Estes suportes devem possuir as mesmas características observadas nos sistemas catalíticos, tais como: atividade, seletividade, estabilidade, resistência mecânica e condutividade térmica (FIGUEIREDO et al., 1989). 


\subsubsection{Alguns Estudos Realizados no País Utilizando Bentonitas}

Um dos pioneiros no país a estudar tecnologicamente as bentonitas da Paraíba foi o prof. Dr. Pérsio de Souza Santos, que em 1976 escreveu sua tese intitulada: "Estudos tecnológicos de argilas montmoriloníticas do Distrito de Boa Vista, município de Campina Grande, Paraíba".

O Departamento de Engenharia de Materiais da UFCG vem realizando estudos sistemáticos das bentonitas do Estado da Paraíba. Destaca-se o prof. Dr. Heber Ferreira, que realizou pesquisas no Instituto de Pesquisas Tecnológicas do Estado de São Paulo, IPT, com argilas da Paraíba.

No grupo de pesquisas do PMT/EPUSP/LMPSol o prof. Dr. Francisco Rolando Valenzuela-Diaz que juntamente com sua equipe de colaboradores (Adriana Cutrim, Guillermo Cortez, Fábio Ésper, dentre outros) vem há aproximadamente 15 anos dedicando-se ao fornecimento de informações técnicocientíficas, através de uma sistemática de ensaios proposta pelo grupo, a respeito das bentonitas do Estado da Paraíba, bem como, ao estudo específico de novas aplicações tecnológicas para essas argilas.

O Centro de Tecnologia do Couro e do Calçado Albano Franco - CTCCSENAI/PB está desenvolvendo projeto de pesquisa sobre a utilização da bentonita como agente coagulante e floculante no tratamento primário físico-químico das estações de efluentes da indústria de curtume. Com isso, o CTCC pretende proporcionar condições para que as indústrias de curtume tratem seus efluentes com redução de custo, devolvendo-os ao meio ambiente isentos de substâncias poluidoras e/ou contaminantes.

A Empresa Brasileira de Pesquisa Agropecuária - EMBRAPA está realizando estudos utilizando-se de bentonita ativada e gelatina como agentes de clarificação para o suco de caju. Os resultados obtidos indicaram que o uso da bentonita promove a otimização da operação de filtração, possibilitando a obtenção de um produto límpido, brilhante e com reduzida adstringência. $O$ produto apresenta um padrão de qualidade condizente com outros sucos clarificados existentes no mercado. O suco de caju atualmente é comercializado nas formas de suco integral, suco concentrado e o clarificado, popularmente conhecido pelo nome "cajuína". 


\subsection{CARACTERIZAÇÕES FÍSICO-QUÍMICAS E MINERALÓGICAS DAS BENTONITAS}

\subsubsection{Fluorescência de raios $X(F R X)$}

Segundo Silva (2008), a análise por Fluorescência de raios X é um método semi-quantitativo baseado na medida das intensidades (número de raios $X$ detectados por unidade de tempo) dos raios $X$ característicos emitidos pelos elementos que constituem a amostra. Os raios $X$ emitidos por tubos de raios $X$ ou gama por uma fonte radioativa, excitam os elementos constituintes, os quais, por sua vez, emitem linhas espectrais com energias características do elemento e cujas intensidades estão relacionadas com a concentração do elemento na amostra (SILVA, 2008)

Quando um elemento de uma amostra é excitado, este tende a ejetar os elétrons do interior dos níveis dos átomos e, como consequência disto, elétrons dos níveis mais afastados realizam um salto quântico para preencher a vacância. Cada transição eletrônica constitui uma perda de energia para o elétron, e esta energia é emitida na forma de um fóton de raios $\mathrm{X}$, com energia característica e bem definida para cada elemento. Assim, de modo resumido, a análise por fluorescência de raios $X$ consiste de três fases: excitação dos elementos que constituem a amostra, dispersão dos raios $X$ característicos emitidos pela amostra e deteç̧ão desses raios $X$. Apesar da análise química não permitir uma avaliação da composição mineralógica e das propriedades físico-químicas e tecnológicas das argilas, mesmo assim, ela fornece dados da composição química fundamental e de grande utilidade industrial e científica. A composição química típica de argilas provenientes de Boa Vista-PB foi descrita em detalhes por estudos realizados por Souza Santos e Valenzuela-Diaz (1992). De acordo com a literatura, para bentonitas "in natura" (VALENZUELA-DÍAZ et. al., 1992), espera-se encontrar como resultados teores de óxidos de $\mathrm{SiO}_{2}$ e $\mathrm{Al}_{2} \mathrm{O}_{3}$, perfazendo assim mais de $75 \%$, sendo provavelmente provenientes dos argilominerais e da sílica livre presente nas amostras, além de outros óxidos em menor proporção como: $\mathrm{TiO}_{2}, \mathrm{MnO}, \mathrm{P}_{2} \mathrm{O}_{5}, \mathrm{Na}_{2} \mathrm{O}, \mathrm{CaO}, \mathrm{MgO}, \mathrm{K}_{2} \mathrm{O}$, dentre outros, dependendo da origem geológica. 


\subsubsection{Difração de raios X (DRX)}

A técnica de difração de raios $X$ permite a identificação da estrutura cristalina, indicando como estão distribuídos os átomos numa determinada estrutura e fornecendo o tamanho médio dos cristalitos, ou ainda determinar a quantidade aproximada de uma certa fase numa amostra. O teor mínimo para a detecção é de aproximadamente $5 \%$ para compostos e $1 \%$ para elementos (SILVA, 2008).

Para argilas, os difratogramas de raios $X$ permitem determinar variações da distância interlamelar das argilas decorrentes dos processos de modificações químicos ou térmicos. Além disso, através dessa é possível confirmar se o material trata-se realmente de uma argila, podendo ainda adquirir informações quantitativas e qualitativas das fases cristalinas presentes numa amostra.

Os raios $X$ são radiações eletromagnéticas da mesma natureza que as radiações que compõem a luz branca visível ao olho humano. A produção de raios $X$ está associada a perdas de energia de elétrons; porém, a quantidade de energia necessária para produzir um quantum de raios $X$ é muito maior que aquela para produzir um quantum visível. Pois, os comprimentos de onda dos raios $X$ são cerca de mil vezes menores que os comprimentos de onda da luz visível, e daí resultam grandes diferenças nas propriedades dos dois tipos de radiação.

Quando uma estrutura cristalina dessa natureza é exposta a um feixe monocromático de raios $\mathrm{X}$, cada cela unitária produz um efeito de difração dos raios $\mathrm{X}$, desde que as unidades constituintes da cela unitária estejam paralelas aos raios incidentes. Contudo, o cristal não produz a imagem difratada da cela unitária intensificada por superposições em todas as direções, porque as ondas da radiação$X$ produzida pelas diversas celas unitárias também interferem destrutivamente entre si. Difratogramas de raios $X$ apresentam a intensidade da difração das radiações nos planos atômicos das amostras em função do ângulo de incidência. Este ângulo é relacionado à distância entre os planos através da lei de Bragg:

$$
\mathrm{n} \lambda=2 . \mathrm{d} \cdot \operatorname{sen} \theta
$$

Onde: $\lambda=$ comprimento de onda da radiação;

$\mathrm{n}=$ número inteiro;

d = distância interlamelar; 
$\theta=$ ângulo de incidência .

\subsubsection{Espectroscopia na Região do Infravermelho (IV)}

Segundo Gomes (2005) apud Lima (2008), os compostos orgânicos absorvem energia eletromagnética na região de infravermelho do espectro. A radiação infravermelha não tem energia suficiente para provocar excitação dos elétrons, mas faz com que os átomos vibrem com maior rapidez e com maior amplitude em torno das ligações covalentes que os unem. As vibrações são quantizadas e, quando ocorrem, os compostos absorvem energia IV em certas regiões do espectro.

Os espectrômetros de infravermelho são equipamentos utilizados para medir a quantidade de luz absorvida em cada comprimento de onda na região de IV. Nesses instrumentos um feixe de luz é dividido em dois; uma das metades dos feixes passa através de uma célula transparente que contém a amostra em análise, e que pode ser sólida, líquida ou gasosa.

A outra metade passa através de outra célula vazia. $O$ instrumento opera de modo que é possível fazer uma comparação entre a intensidade dos dois feixes, em cada comprimento de onda da região. Se a amostra absorver luz num determinado comprimento de onda, a intensidade do feixe da amostra será menor do que a do feixe de referência. $O$ espectrômetro plota os resultados na forma de um gráfico que mostra a absorção em função da frequência ou do comprimento de onda.

A técnica de espectroscopia na região do infravermelho é utilizada para verificar as bandas de absorção características de cada material. De forma resumida, para as argilas são observadas através dessa técnica os valores para as seguintes absorções características: da presença de hidroxilas, de água adsorvida, das ligações Si-O-Si e da camada octaédrica.

Usualmente, as argilas esmectíticas "in natura" típicas da Paraíba apresentam as seguintes absorções: a $3510 \mathrm{~cm}^{-1}$ banda característica da presença de hidroxilas; a $1655 \mathrm{~cm}^{-1}$ banda característica de água adsorvida; a $1082 \mathrm{~cm}^{-1}$ banda característica de ligações Si-O-Si, e nas faixas de 534 e $476 \mathrm{~cm}^{-1}$ banda característica da camada octaédrica (SILVA, 2008). 


\subsubsection{Microscopia Eletrônica de Varredura (MEV) / Espectroscopia por Energia Dispersiva (EDS)}

A técnica de microscopia eletrônica de varredura (MEV) é utilizada para argilas quando se deseja obter informações da estrutura de um material, além de permitir a identificação de uma microestrutura utilizando a técnica de difração de elétrons ou a imagem obtida em alta resolução. Pode-se também obter, utilizando o mesmo equipamento, a identificação química qualitativa de pequenas partículas da argila visualizadas pelo microscópio através de emissões de raios $X$ específicos para cada elemento, por meio da técnica de energia dispersiva de raios $X$ (EDS). Seus resultados são exibidos em gráficos e é sempre empregada como uma técnica complementar.

\subsubsection{Análise Textural (BET)}

Segundo Silva (2008), a caracterização textural é fundamental para se compreender o comportamento cinético dos materiais através da determinação dos seguintes parâmetros: área específica, volume específico de poros, porosidade e distribuição do tamanho de poros. Os poros são geralmente classificados em três grupos, de acordo com seu tamanho: macroporos (>50 nm), mesoporos (2 a $50 \mathrm{~nm}$ ) e microporos $(<2 \mathrm{~nm})$.

As isotermas de adsorção de uma substância sobre um adsorvente é a função que relaciona, à temperatura constante, a quantidade de substância adsorvida em equilíbrio com sua pressão ou concentração na fase gasosa. A determinação experimental de isotermas de adsorção pode ser feita por métodos estáticos ou dinâmicos (GREGG \& GARDNER SUMMER, 1982).

\subsubsection{Análises Térmicas}

Para a avaliação do comportamento térmico das argilas, geralmente se utiliza um analisador térmico simultâneo no qual obtemos resultados de análise térmica diferencial e termogravimétrico 
Segundo Silva (2008), a análise térmica diferencial (DTA) é um instrumento de pesquisa muito importante em cerâmica, pois permite acompanhar as transformações que sofrem as argilas e as massas cerâmicas durante a queima.

A análise termogravimétrica determina a variação de massa de uma amostra em função da temperatura. A curva resultante fornece informações sobre estabilidade térmica, composição da amostra inicial e composto intermediários que por ventura se formem no decorrer da análise. 
CAPÍTULO 3 MATERIAIS E MÉTODOS 


\section{CAPÍTULO 3- MATERIAIS E MÉTODOS}

Neste capítulo serão apresentados os materiais e a metodologia aplicada na para a execução deste trabalho. Serão detalhadas as 3 etapas metodológicas.

\subsection{Materiais Argilosos}

Foram fornecidas um total de 5 amostras de bentonitas diferentes para 0 desenvolvimento dessa pesquisa, pela empresa de minerais não-metálicos BENTONISA - Bentonita do Nordeste S.A. Esses materiais, encontravam-se nas formas "in natura" e todos foram extraídos da mina denominada Lages, localizada na Paraíba, no município de Boa Vista.

\subsection{Metodologia}

A metodologia desse trabalho está dividida em 3 etapas:

ETAPA 1 - Identificação das bentonitas;

ETAPA 2 - Caracterização das bentonitas selecionadas;

ETAPA 3 - Indicações de aplicações e usos potenciais das bentonitas.

\subsubsection{ETAPA 1: Identificação das bentonitas}

As amostras de argilas utilizadas nesta pesquisa foram selecionadas de acordo com a região que estavam localizadas e o tipo ("in natura"). Na tabela 12, estão descritos esses materiais argilosos.

Tabela 12: Argilas fornecidas pela empresa BENTONISA.

\begin{tabular}{cccc} 
AMOSTRAS & TIPO ARGILAS & ORIGEM & $\begin{array}{c}\text { NOMENCLATURA } \\
\text { REGIONAL }\end{array}$ \\
& Bentonita "In natura" & Mina Lages/ Boa Vista-PB & Chocolate \\
A2 & Bentonita “In natura" & Mina Lages / Boa Vista-PB & Bofe \\
A3 & Bentonita "In natura" & Mina Lages / Boa Vista-PB & Chocobofe \\
A4 & Bentonita “In natura" & Mina Lages / Boa Vista-PB & Sortida \\
A5 & Bentonita “In natura" & Mina Lages / Boa Vista-PB & Verde Lodo \\
\hline
\end{tabular}




\subsubsection{ETAPA 2: Caracterização das Bentonitas Selecionadas}

Foram realizadas caracterizações físico-químicas e mineralógicas das 5 amostras de bentonitas em estudo na forma como recebida. Os resultados dessas caracterizações encontram-se apresentados e discutidos no capítulo 4.

\subsubsection{Caracterização Físico- Química e Mineralógica}

Dentre os principais ensaios de caracterização físico-químicas, foram aplicados:

- Teor de Umidade;

- Teor de Areia;

- Massa Específica Aparente;

- CTC;

- Grau de Finura;

- Granulometria;

- $\mathrm{pH}$.

- Inchamento de Foster em água;

- Microscopia Eletrônica de Varredura (MEV); Espectroscopia de Dispersão de Raios X (EDS);

- Espectroscopia na Região do Infravermelho (IV);

- Fluorescência de Raios X (FRX);

- Análise Textural (método BET).

Dentre os principais ensaios de caracterização mineralógica, foram aplicados:

- Difração de Raios X (DRX);

- Análise Térmica (TG e DTA);

As análises de teor de umidade, teor de areia, massa específica aparente, granulometria e $\mathrm{pH}$ foram realizadas nos laboratórios do Centro de Pesquisas Tecnológicas - CPTECH/BENTONISA. 


\subsection{Teor de Umidade}

O teor de umidade das amostras de argilas naturais foi determinado segundo norma CPTECH/BENTONISA detalhada abaixo.

Pesou-se $1 \mathrm{~g}$ de amostra em um vidro de relógio sobre balança analítica, e esta amostra foi levada para microondas, deixando por $4 \mathrm{~min}$ na potência 10 do aparelho. Transferiu-se a amostra do microondas diretamente para o dessecador, até atingir temperatura ambiente. A partir daí pesou-se o vidro com a amostra, e calculou-se o teor de umidade segundo a fórmula:

$$
T U=\underline{(P U-P S}) \times 100
$$

PU

Onde: $\mathrm{PU}=$ peso amostra úmida

$\mathrm{PS}=$ peso amostra seca

$\mathrm{TU}=$ teor de umidade

\subsection{Teor de Areia}

O teor de areia das amostras de argilas naturais foi determinado segundo norma CPTECH/BENTONISA detalhada abaixo.

Colocou-se $500 \mathrm{ml}$ de água em copo do equipamento Hamilton Beach (HB). Pesou-se $12,5 \mathrm{~g}$ da amostra e colocou-se o copo com água para agitar no equipamento HB, na velocidade 1. A amostra foi adicionada aos poucos, e ao final da adição marcou-se o tempo de 15 min;

Após 2 min de agitação, retirou-se o copo e passou-se um bastão pelas paredes internas do mesmo para retirar possíveis grânulos aderidos; fez-se isto em no máximo $30 \mathrm{~s}$, colocando o copo de novo no equipamento, segundo procedimento 
de análise. Ao término da agitação, retirou-se a suspensão ("lama") e fez-se a leitura do teor de areia no KIT FANN 209697 da seguinte forma:

a) Pegando a peneira do KIT e passando a suspensão na parte desta peneira com o lado para filtração da areia voltada para baixo;

b) Invertendo a peneira e acoplando em funil, para a areia aderida ser retirada para um tubo de coleta de vidro;

c) Lavando a peneira com água por completo, até passar toda a areia para o tubo;

d) Enchendo o tubo com água até certa marca de aferição;

e) Esperando a água ficar límpida e medindo o nível de areia na graduação do vidro.

\subsection{Massa Específica Aparente}

A massa específica aparente das amostras de argilas naturais foi determinada segundo norma CPTECH/BENTONISA detalhada abaixo.

Pesou-se uma proveta de $100 \mathrm{ml}$ com suporte plástico, adicionou-se cerca de $30 \mathrm{~g}$ da amostra na proveta e foi-se compactando com 10 batidas leves na bancada (superfície uniforme). E assim fez-se adição e compactação da amostra a cada $30 \mathrm{~g}$ até atingir a aferição na proveta. Pesou-se a proveta com a amostra, e então se calculou a massa específica da amostra $\left(\mathrm{g} / \mathrm{ml}=\mathrm{g} / \mathrm{cm}^{3}\right)$, conforme a igualdade:

$\mu=\left[\left(m_{\text {proveta+sólido }}\right)-\left(m_{\text {proveta }}\right)\right] / 100$.

Onde: $\mu=$ massa específica aparente

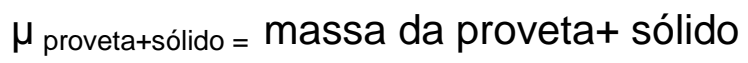

$\mu_{\text {proveta }}=$ massa da proveta

\subsection{Capacidade de Troca de Cátions}


A capacidade de troca de cátions das amostras de argilas naturais foi realizada por Empresa Pernambucana de Pesquisa Agropecuária - IPA segundo norma própria desenvolvida por esta instituição.

\subsection{Grau de Finura e Granulometria}

O grau de finura ou teor de resíduo retido em peneira ABNT no 200 (0,075 $\mu \mathrm{m})$ das amostras de argilas naturais foi determinado segundo norma N-2605 (PETROBRAS, 1998a).

A granulometria das amostras de argilas naturais foi determinada segundo norma CPTECH/BENTONISA detalhada abaixo.

Pesou-se a massa de $100 \mathrm{~g}$ da amostra, colocou-se a amostra na primeira peneira (60 MESH) da série de peneiras $(60,100,150,200,270,325 \mathrm{MESH})$. Ajustou-se a série de peneiras (incluindo o fundo) no agitador vibracional e prendeuse bem na estrutura deste. O equipamento foi ligado para operar durante $15 \mathrm{~min}$ sob vibração constante e após este tempo, retirou-se as peneiras, pesando as quantidades de amostra retida em cada uma delas separadamente. Enfim, calculouse a porcentagem de amostra retida e o total de amostra após peneiramento. A maior quantidade de amostra retida em uma peneira representa a granulometria da peneira anterior, porque por esta passou a grande quantidade do material.

\subsubsection{6 pH}

$\mathrm{O} \mathrm{pH}$ das amostras de argilas naturais foi determinado segundo norma CPTECH/BENTONISA detalhada abaixo.

Preparou-se uma suspensão com 24,3 g de amostra e $500 \mathrm{ml}$ de água, agitando-se constantemente no equipamento Hamilton Beach. Então, mediu-se o pH no equipamento Ph BANC II da marca Caal. Esperou-se que o equipamento estabilizasse a leitura, e fez-se a leitura do $\mathrm{pH}$, dado no monitor do aparelho. 


\subsection{Inchamento de Foster}

O Inchamento de Foster das amostras de argilas naturais foi determinado segundo norma CPTECH/BENTONISA detalhada abaixo.

Pesou-se $2 \mathrm{~g}$ de argila apropriadamente em vidro de relógio sobre balança analítica, e aferiu-se proveta de $100 \mathrm{ml}$ com solvente (para este caso foi água). Adicionou-se lentamente a argila na proveta, de modo que decantasse no solvente por gravidade. Ao terminar a adição, realizou-se leitura imediata do nível de argila na proveta $(\mathrm{ml})$, após $1 \mathrm{~h}$, e depois de $24 \mathrm{~h}$.

De acordo com Valenzuela-Diaz (1994) e devido aos diversos estudos (PEREIRA et.al 2004; PEREIRA ; RODRIGUES; VALENZUELA DIAZ,2007; RAMOS VIANA et.al. 2005; VIEIRA JOSÉ et.al. 2002, BOTELHO et.al.2007) que vêm sendo efetuados no Laboratório de Matérias-Primas Particulados e Sólidos Não Metálicos da Escola Politécnica da Universidade de São Paulo (LMPSol/EPUSP), foram adotadas as seguintes considerações para o teste de inchamento de Foster:

a) Não-Inchamento: Igual ou inferior a $2 \mathrm{~mL} / \mathrm{g}$;

b) Baixo: 3 a $5 \mathrm{~mL} / \mathrm{g}$;

c) Médio: 6 a $8 \mathrm{~mL} / \mathrm{g}$;

d) Alto: Acima de $8 \mathrm{~mL} / \mathrm{g}$.

\subsection{Difração de raios- $X(D R X)$}

De forma geral, mediante a difração de raios $X$ é possível identificar o material cristalino e determinar variações da distância interlamelar dos argilominerais.

Visando a determinação das fases cristalinas presentes nas amostras foi utilizada a técnica de difração de raios $X$ (DRX) empregando o método do pó. Os ensaios foram realizados utilizando o equipamento denominado difratômetro da marca Shimadzu modelo XRD 600, com radiação de CuKa (30 kV e 15 mA), sendo o 
intervalo $2^{\circ}<2 \Theta<80^{\circ}$ com passo de $0,02^{\circ}$ e aquisição de 0,6 segundos por passo. Os dados da análise foram obtidos através do software Shimadzu.

A análise de DRX foi realizada no Laboratório de Ensaios dos Materiais localizado no Centro de Tecnologia do Gás (CTGÁS) em Natal-RN.

\subsection{Análise Térmica (TG e DTA)}

A análise térmica diferencial é um instrumento de pesquisa muito importante em cerâmica, pois permite acompanhar as transformações que sofrem as argilas e as massas cerâmicas durante a queima.

A análise termogravimétrica determina a variação de massa de uma amostra em função da temperatura. A curva resultante fornece informações sobre estabilidade térmica, composição da amostra inicial e compostos intermediários que por ventura se formem no decorrer da análise.

O equipamento utilizado para realização das análises térmicas foi BP3000 engenharia, que operou sob atmosfera ambiente no laboratório, pertencente ao Laboratório de Combustíveis e Materiais (LACOM) da Universidade Federal da Paraíba (UFPB), em João Pessoa.

\subsubsection{Microscopia Eletrônica de Varredura (MEV) / Espectroscopia por Energia Dispersiva (EDS)}

As técnicas de microscopia eletrônica de varredura e espectroscopia por energia dispersiva (MEV/EDS) utilizou-se de um microscópio eletrônico de varredura da marca Philips, modelo XL30. As amostras receberam recobrimento em ouro. As análises de MEV e EDS foram realizadas no Laboratório de Microscopia Eletrônica do Departamento de Engenharia Metalúrgica e Materiais, da Escola Politécnica da Universidade de São Paulo (PMT/EPUSP), e foram tiradas micrografias com aumento de 20000X para cada amostra. 


\subsection{Espectroscopia na Região do Infravermelho (IV)}

A partir da análise de espectroscopia de absorção no infravermelho foi possível observar os perfis de curvas dos materiais que apresentam os espectros vibracionais na região do infravermelho. Estas análises foram realizadas no LACOM - Laboratório de Combustíveis e Materiais, da Universidade Federal da Paraíba, situado em João Pessoa-PB, em um espectrômetro Nicolet Magma IR 560, acoplado a um microcomputador com registros da faixa espectral de 4000 a $400 \mathrm{~cm}^{-1}$, com resolução de $4 \mathrm{~cm}^{-1}$, fazendo 64 varreduras, purga com ar comprimido, com acessório de transmissão.

A preparação das amostras foi feita pela técnica da pastilha, misturando brometo de potássio em pó $(\mathrm{KBr})$ à amostra finamente pulverizada e, a seguir, a mistura foi prensada até a obtenção de um disco.

\subsection{Fluorescência de Raios X (FRX)}

A análise da composição química das argilas foi determinada pela técnica de fluorescência de raios $X$. O equipamento utilizado foi um espectrômetro de fluorescência de raios $X$ da marca Shimadzu modelo EDX 700 , dotado de tubo gerador de raios $X$ de ródio. A contagem dos pulsos foi realizada através de um detector proporcional de fluxo. O equipamento tem capacidade para realizar as análises dos elementos de sódio a urânio. Os dados da análise foram obtidos através do software Shimadzu.

A análise de FRX foi realizada no laboratório de Ensaios dos Materiais localizado no Centro de Tecnologia do Gás (CTGÁS), em Natal-RN.

\subsection{Análise Textural (BET)}


As propriedades texturais das argilas (área específica, volume poroso e diâmetro do poro) foram determinadas por fisissorção de $N_{2}$. A análise foi realizada em um equipamento Tristar modelo 2000 da Micromeritics. As amostras, após a pesagem, foram submetidas à secagem a $300 \stackrel{\circ}{\circ}$ durante 24 horas sob vácuo. Em seguida, as amostras foram novamente pesadas e iniciadas as análises, obtendo-se isotermas de adsorção de $\mathrm{N}_{2}$ a $-196{ }^{\circ} \mathrm{C}$, em diferentes pressões parciais de $\mathrm{N}_{2}$.

A partir destes resultados foi possível determinar a área específica pelo método $\mathrm{BET}$, o qual se baseia nos dados de adsorção na faixa de pressão relativa (P/Po) de 0,5 a 0,30 (BRUNAUER et al., 1938).

$\mathrm{O}$ diâmetro do poro foi determinado usando método BJH (BARRET et al., 1953) e o volume poroso pela quantidade de nitrogênio adsorvido a $P / P o$ igual a 0,95 .

A análise de BET foi realizada no Laboratório de Combustíveis e Materiais (LACOM) da Universidade Federal da Paraíba .

\subsubsection{ETAPA 3: Indicações de Aplicações e Usos Potenciais das Bentonitas}

Baseado nos resultados das caracterizações físicas e mineralógicas será realizada a indicação de alguns usos potenciais das 5 amostras de bentonitas em estudo. Estes encontram-se detalhado no capítulo 5. 


\section{CAPÍTULO 4 - DISCUSSÃO E ANÁLISE DOS RESULTADOS}




\section{CAPÍTULO 4- DISCUSSÃO E ANÁLISE DOS RESULTADOS}

Neste capítulo serão apresentados e discutidos os resultados das caracterizações das bentonitas da Paraíba. Para esta etapa do trabalho foram detalhados os resultados de 5 bentonitas oriundas da Mina Lages (Boa Vista-PB).

\subsection{Caracterização das Bentonitas}

\subsubsection{Caracterização Físico-Química e Mineralógica}

A tabela 13 apresenta os valores obtidos a partir da caracterização físicoquímica das argilas "in natura": Chocolate; Bofe; Chocobofe; Sortida e Verde Lodo.

Tabela 13: Resultados das Caracterizações Físico-químicas das Bentonitas da Mina Lages.

\begin{tabular}{|c|c|c|c|c|c|}
\hline Testes/ Argilas & Chocolate & Bofe & Chocobofe & Sortida & Verde Lodo \\
\hline $\begin{array}{c}\text { Teor de Umidade } \\
(\%)\end{array}$ & 7,33 & 8,8 & 10,34 & 7,57 & 3,83 \\
\hline $\begin{array}{c}\text { Teor de Areia } \\
(\%)\end{array}$ & 1 & 1 & 1,5 & 2 & 0,25 \\
\hline $\begin{array}{c}\text { Massa Específica } \\
\text { Aparente } \\
(\mathrm{g} / \mathrm{mL})\end{array}$ & 0,93 & 0,96 & 1,11 & 1,15 & 0,98 \\
\hline $\begin{array}{c}\text { Capacidade de Troca } \\
\text { de Cátions } \\
\text { (meq/100g) }\end{array}$ & 59,82 & 28,69 & 56,10 & 56,02 & 65,90 \\
\hline $\begin{array}{c}\text { Grau de Finura } \\
(\%)\end{array}$ & 0,40 & 0,04 & 0,26 & 0,50 & 0,06 \\
\hline Granulometria & \#200 & \#200 & \#200 & \#200 & \#200 \\
\hline $\mathrm{pH}$ & 8,5 & 7,4 & 8,4 & 9,0 & 9,4 \\
\hline $\begin{array}{c}\text { Inchamento Foster } \\
\text { em água } \\
(\mathrm{mL})\end{array}$ & 7 & 6 & 10 & 11 & 5 \\
\hline
\end{tabular}


Analisando os resultados obtidos para a caracterização físico-química das argilas em estudo, foi possível observar que com relação ao teor de umidade, a amostra Chocobofe possui um teor maior (10,34\%) que as demais. A argila Verde Lodo apresentou um menor teor de umidade $(3,83 \%)$. Este fato poderá influenciar significativamente em algumas aplicações, como por exemplo: biodiesel e em fluídos de perfuração.

Para a aplicação de biodiesel: o teor de água poderá influenciar na reação de produção do biodiesel, pois segundo Schuchardt et. al., (1998) a presença de água durante a reação de transesterificação favorece inevitavelmente a formação de sabão paralelamente a sua conversão em ésteres gerando dificuldades de purificação, formação de emulsão e perdas de rendimento; Para a aplicação em fluídos de perfuração: segundo que as especificações da Petrobras (1998), o teor de umidade das argilas naturais e aditivadas não deve ultrapassar 14,0\%, logo, observando-se os dados apresentados na tabela 13, foi possível verificar que todas as amostras apresentam um teor de umidade abaixo do máximo permitido. Este resultado também foi encontrado por Amorim (2003), a qual ressaltou que o limite de $14 \%$ determinado pela Petrobras representa um teor de umidade elevado para as argilas de Boa Vista-PB e que provavelmente este valor foi especificado pela Petrobras para evitar problemas de rehidratação, frequentemente ocasionados quando as bentonitas são secas em temperaturas elevadas (acima de $60^{\circ} \mathrm{C}$ ). Logo, percebe-se a importância e a necessidade de medir corretamente o teor de umidade, bem como, realizar uma secagem das argilas de forma adequada antes de utilizá-las em algumas aplicações.

Com relação ao teor de areia verifica-se que a argila Verde Lodo possui cerca de 4 vezes menos areia $(0,25 \%)$ quando comparada a argila Sortida $(2 \%)$. Verificando-se então que a argila Verde Lodo está mais livre de contaminações e impurezas que a argila Sortida. Esse fato da argila Sortida possuir um teor de areia maior que as demais já era esperado, devido ao fato da mesma ter em sua composição a mistura das demais argilas, ou seja, mistura da argila Chocolate, com Chocobofe, com Bofe e com Verde Lodo, isso implica que o teor de contaminantes da argila Sortida poderá ser provavelmente maior. 
Os valores da massa específica aparente obtidos para as argilas em estudo, mostram que estas tiveram resultados semelhantes, próximos de $1 \mathrm{~g} / \mathrm{ml}$ devido ao fato de que as argilas em estudo serem do mesmo tipo, ou seja, bentonitas. Este resultado foi obtido comparando as argilas em estudo com o padrão na norma CPTECH/BENTONISA.

Com relação ao CTC, as mesmas apresentam-se dentro da faixa para argilas "in natura" que não incham em água. Segundo Grim (1968), as bentonitas apresentam valores de CTC entre 50 e $90 \mathrm{meq} / 100 \mathrm{~g}$ de argila. Destaca-se a argila Bofe como sendo a argila que apresenta uma menor capacidade de troca catiônica $(28,69 \mathrm{meq} / 100 \mathrm{~g})$, fato que provavelmente explica a sua dificuldade de ativação por barrilha, quando comparada as demais argilas, relatada pelas indústrias durante 0 processo de ativação por sódio. Estes valores também se encontram dentro dos parâmetros reportados por Pereira (2008), o qual relata que os menores valores de CTC indicam que os argilominerais apresentam uma alta quantidade de impurezas ou um baixo nível de substituições isomórficas.

Na tabela 13 estão apresentados os resultados obtidos para o grau de finura ou teor de resíduo em peneira ABNT no $200(0,075 \mu \mathrm{m})$. Os resultados para o grau de finura variaram 0,04\% para 0,5\%. Dentre as argilas estudadas destacam-se as argilas Bofe e Verde Lodo como sendo as que apresentaram um menor teor de resíduo em peneira. Este é um parâmetro bastante importante para a aplicação de fluidos de perfuração, ressalta Amorim (2003), pois segundo as especificações da Petrobras (1998), o teor de resíduo das argilas naturais e aditivadas não deve ser superior a 4,0\%, ou seja, as argilas não podem apresentar teor de acessórios, ou materiais inertes, em teores acima de 4,0\%. O limite de 4,0\% é imposto para evitar que argilas com teores expressivos de minerais acessórios possam ser utilizadas nesse processo. Logo, para aplicação em fluidos de perfuração, observa-se que todas as amostras apresentaram resíduo em peneira ABNT no 200 abaixo do máximo permitido, estando portanto aprovadas para tal finalidade. Também verificou-se nesse estudo que as mesmas apresentam comportamentos similares, por terem quase $70 \%$ de material passante na malha \#200 mesh. Logo, as argilas analisadas através da tabela 13 encontram-se na granulometria padrão para comercialização das indústrias. 
Com base nos resultados de $\mathrm{pH}$ das argilas em estudo, tem-se que a argila Verde Lodo é mais básica do que as demais. Tendo, portanto, potencialidade para ser utilizada em diversas aplicações, como por exemplo, cosméticos e também biodiesel, pois poderia atuar numa catálise básica heterogênea via transesterificação para produzir o biodiesel (SILVA, 2008).

Adotando-se as considerações para o inchamento de Foster em água descritas anteriormente na metodologia, foi possível observar que houve variações entre baixo inchamento (Verde Lodo), médio inchamento (Chocolate e Bofe) e alto inchamento (Chocobofe e Sortida). Estes resultados também foram observados por Pereira (2003) e Valezuela-Diaz (1994), os mesmos também utilizaram esse método para determinar o inchamento de argilas organofílicas em solventes orgânicos.

\subsubsection{Difração de raios $X(D R X)$}

A caracterização das amostras por difração de raios $X$ visa verificar a existência de minerais acessórios e de argilominerais (figura 38).

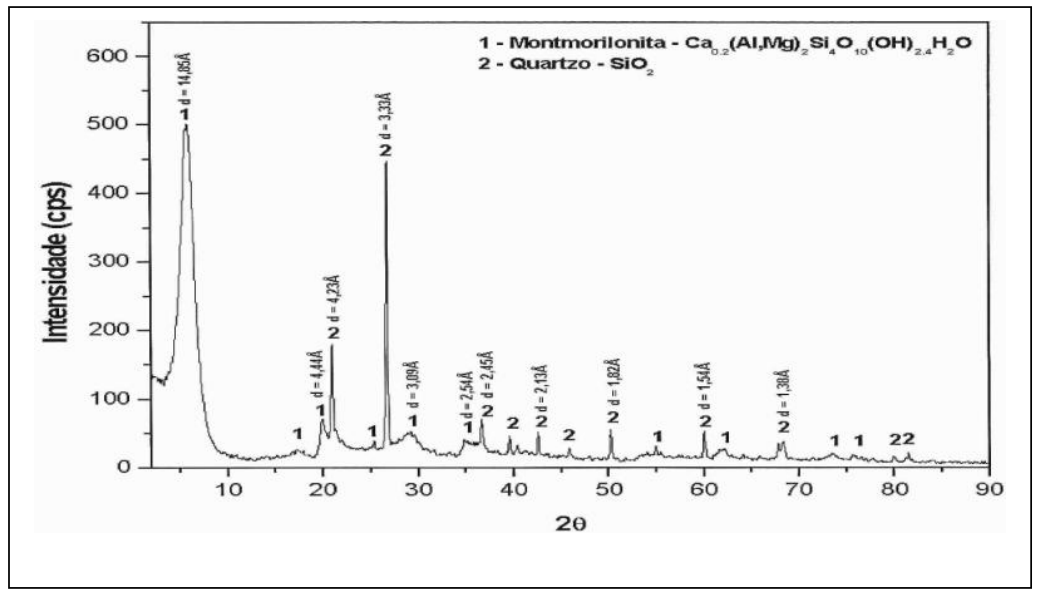

(a) Chocolate Laqes

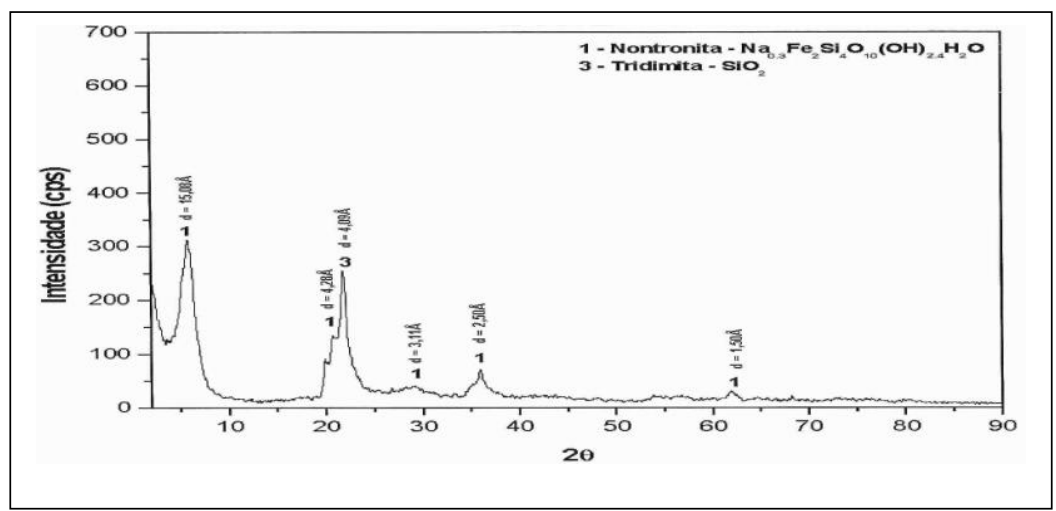

(b) Bofe Lages 


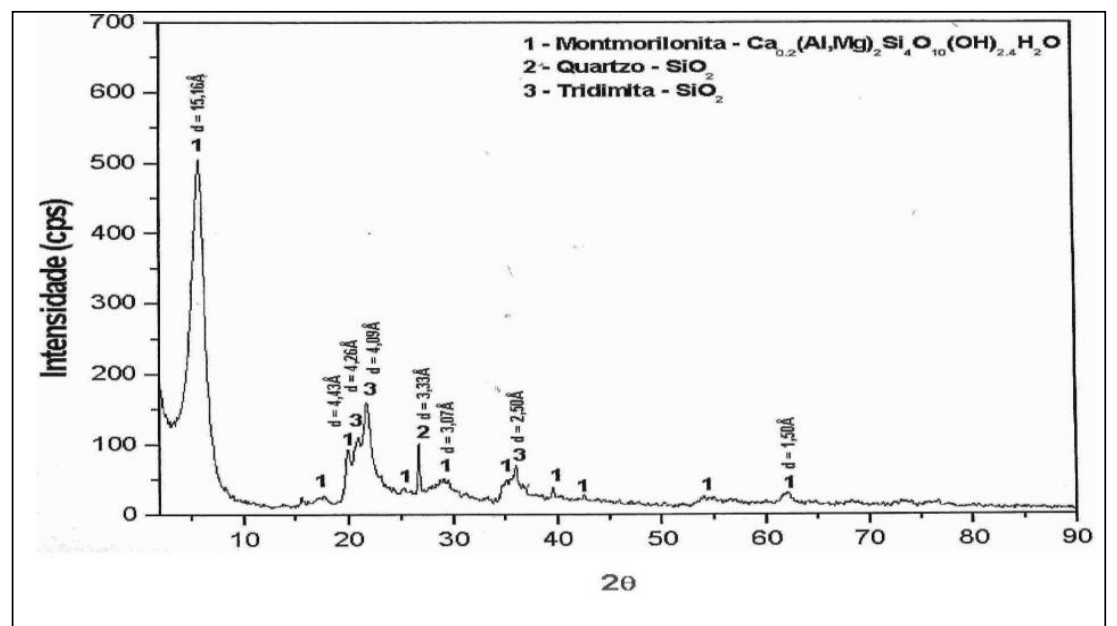

(c) Chocobofe Lages

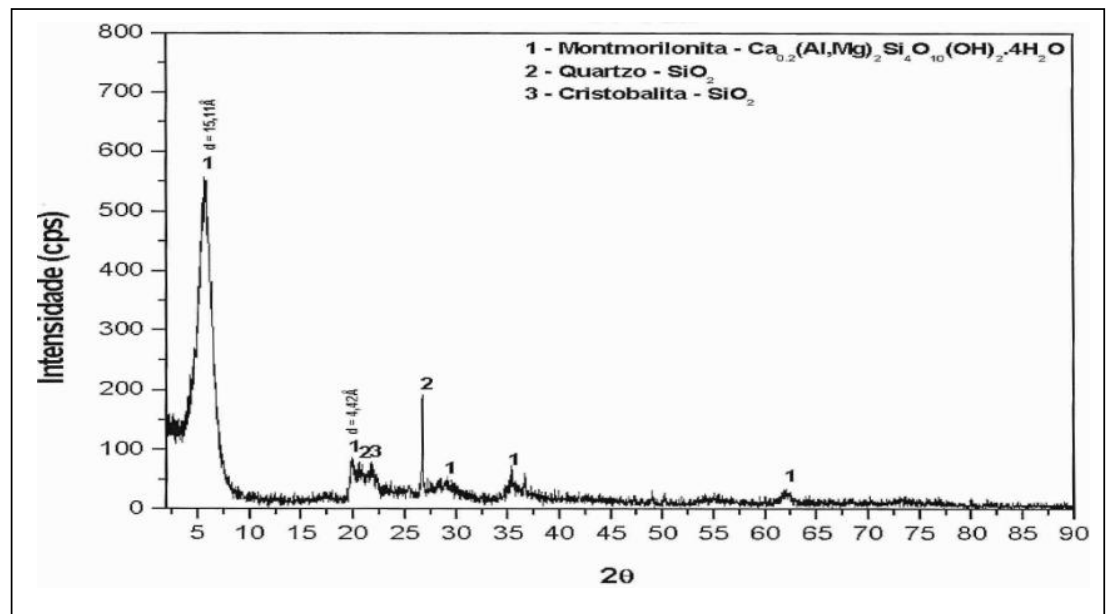

(d) Sortida Lages

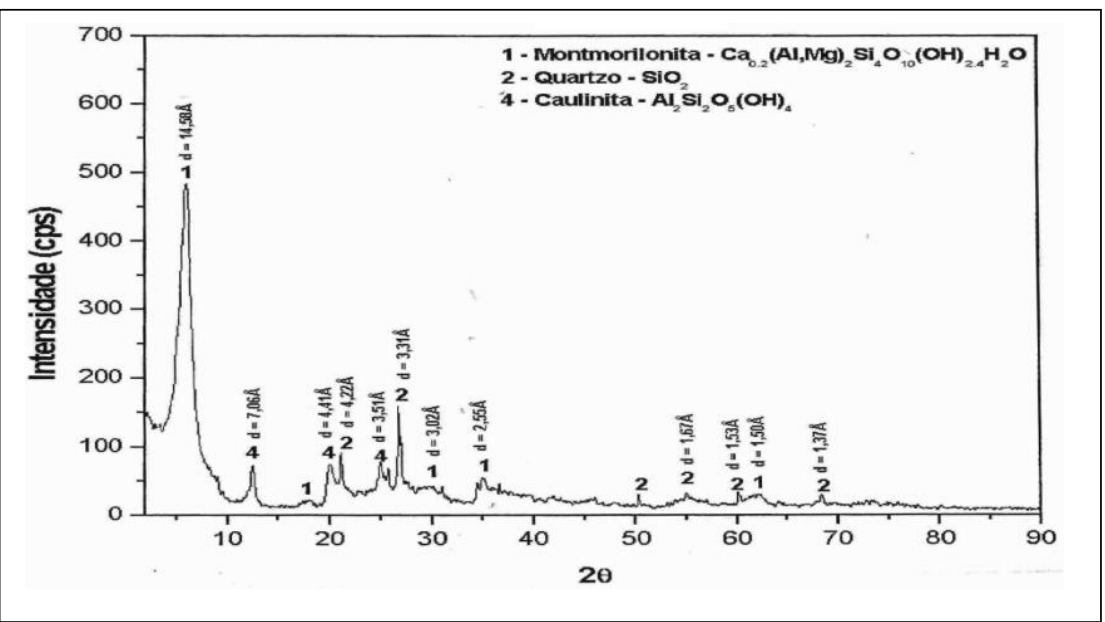

(e) Verde Lodo Lages

Figura 38: Curvas de difração de raios- $X$ das bentonitas da mina Lages: (a) Chocolate; (b) Bofe; (c) Chocobofe; (d) Sortida; (e) Verde Lodo. 
Através da figura 38 , encontram-se as curvas de difração de raios $\mathrm{X}$, obtidas pelo método do pó, para as argilas consideradas "in natura": Chocolate; Bofe; Chocobofe; Sortida e Verde Lodo. E na tabela 14 estão apresentados de forma resumida os resultados referentes aos argilominerais presentes e ao espaçamento basal $d_{001}$.

Tabela 14: Resultados referentes aos argilominerais presentes e a do01.

\begin{tabular}{|c|c|c|}
\hline Argila & Argilominerais Presentes & $d_{001}$ \\
\hline Chocolate Lages & $\begin{array}{l}\text { 1- Montmorilonita - } \\
\quad \mathrm{Ca}_{0.2}\left(\mathrm{Al}, \mathrm{Mg}_{2} \mathrm{~S}_{4} \mathrm{O}_{10}(\mathrm{OH})_{2.4} \mathrm{H}_{2} \mathrm{O}\right. \\
\text { 2- Quartzo- } \mathrm{SiO}_{2}\end{array}$ & 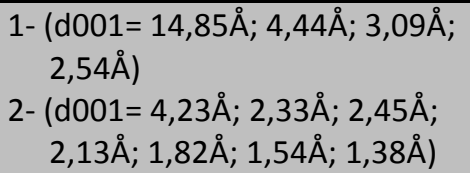 \\
\hline Bofe Lages & $\begin{array}{l}\text { 1- Montmorilonita - } \\
\quad \mathrm{Ca}_{0.2}(\mathrm{Al}, \mathrm{Mg})_{2} \mathrm{Si}_{4} \mathrm{O}_{10}(\mathrm{OH})_{2.4} \mathrm{H}_{2} \mathrm{O} \\
\text { 2- Quartzo- } \mathrm{SiO}_{2}\end{array}$ & $\begin{array}{l}1-(\mathrm{d} 001=15,58 \AA) \\
2-(\mathrm{d} 001=4,08 \AA \AA ; 2,50 \AA ̊)\end{array}$ \\
\hline Chocobofe Lages & $\begin{array}{l}\text { 1- Montmorilonita - } \\
\qquad \mathrm{Ca}_{0.2}(\mathrm{Al}, \mathrm{Mg})_{2} \mathrm{Si}_{4} \mathrm{O}_{10}(\mathrm{OH})_{2.4} \mathrm{H}_{2} \mathrm{O} \\
\text { 2- Quartzo- }-\mathrm{SiO}_{2} \\
\text { 3- Tridimita - } \mathrm{SiO}_{2}\end{array}$ & 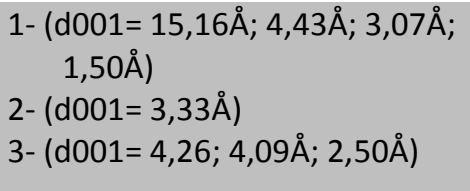 \\
\hline Sortida & $\begin{array}{l}\text { 1- Montmorilonita - } \\
\quad \mathrm{Ca}_{0.2}(\mathrm{Al}, \mathrm{Mg})_{2} \mathrm{Si}_{4} \mathrm{O}_{10}(\mathrm{OH})_{2.4} \mathrm{H}_{2} \mathrm{O} \\
\text { 2- Quartzo- } \mathrm{SiO}_{2} 3 \text { - Cristobalita - } \mathrm{SiO}_{2}\end{array}$ & 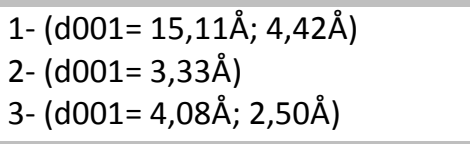 \\
\hline Verde Lodo Lages & $\begin{array}{l}\text { 1- Montmorilonita - } \mathrm{Ca}_{0.2}(\mathrm{Al}, \mathrm{Mg})_{2} \mathrm{Si}_{4}(\mathrm{OH})_{2.4} \mathrm{H}_{2} \mathrm{O} \\
\text { 2- Quartzo - } \mathrm{SiO}_{2} \\
\text { 4- Caulinita - } \mathrm{Al}_{2} \mathrm{Si}_{2} \mathrm{O}_{5}(\mathrm{OH})_{4}\end{array}$ & 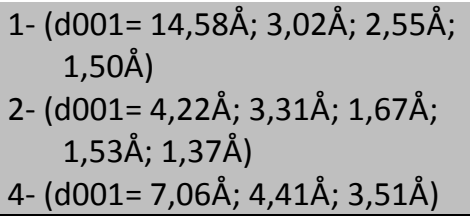 \\
\hline
\end{tabular}

Ao observar as curvas de difração de raios $\mathrm{X}$ da figura 38 foi possível verificar que:

(a) A bentonita Chocolate Lages "in natura" é formada por uma mistura de argilomineral montmorilonita e quartzo. Apresentando pico principal a $14,85 \AA$ característico da presença do argilomineral do grupo da esmectita e pico a $4,23 \AA$, característico da presença de quartzo;

(b) A bentonita Bofe Lages "in natura" é formada por uma mistura de argilomineral montmorilonita e quartzo. Apresentando pico principal a $15,58 \AA$ característico da presença do argilomineral do grupo da esmectita e pico a $4,08 \AA$, característico da presença de quartzo; 
(c) A bentonita Chocobofe Lages "in natura" é formada por uma mistura de argilomineral montmorilonita, quartzo e tridimita. Apresentando pico principal a $15,16 \AA$ característico da presença do argilomineral do grupo da esmectita e pico a $3,33 \AA$ e 4,26 $\AA$, característico da presença de quartzo e tridimita respectivamente;

(d) A bentonita Sortida Lages "in natura" é formada por uma mistura de argilomineral montmorilonita, quartzo e cristobalita. Apresentando pico principal a $15,11 \AA$ característico da presença do argilomineral do grupo da esmectita e pico a 3,33 $\AA$ e $4,08 \AA$, característico da presença de quartzo e cristobalita respectivamente;

(e) A bentonita Verde Lodo Lages "in natura" é formada por uma mistura de argilomineral montmorilonita, quartzo e caulinita. Apresentando pico principal a $14,58 \AA ̊$ característico da presença do argilomineral do grupo da esmectita, pico a $4,22 \AA$, característico da presença de quartzo e pico a $4,22 \AA$, caraterístico da caulinita;

A análise destes resultados revelaram que em todas as amostras há a presença de reflexão do grupo esmectita, identificada pelo argilomineral montmorilonita, que corresponde à distância basal $\left(\mathrm{d}_{001}\right)$ 14,58 - 15,16Á (Tabela 14). Observa-se um valor superior para a argila Chocobofe $(15,16 \AA \hat{)})$, este resultado já era esperado devido esse material ser considerado uma mistura entre as argilas Chocolate e Bofe. Também se percebe um valor elevado para a argila Sortida $(15,11 \AA \hat{)})$, este material trata-se da mistura de todas as argilas oriundas da mina Lages. Observando-se também, picos que correspondem aos minerais acessórios, quartzo, tridimita e a caulinita para as argilas em estudo, exceto para a Chocolate (Tabela 14).

Comparando estes resultados de DRX ao de teor de areia, apresentado anteriormente, percebe-se que as argilas Sortidas e Chocobofe contém um teor de quartzo considerável em suas composições, provavelmente devido a sua forma de extração e aos resíduos de quartzo existentes nas demais argilas que fazem parte das suas composições. Ressalta-se, que esse fato para determinadas aplicações, como por exemplo: cosméticos, não é considerado favorável possuir um teor de areia alto.

Em resumo, os espectros de difração de raios $X$ confirmam que as argilas naturais são amostras de bentonitas, compostas predominantemente por argilominerais do grupo da esmectita, provavelmente montmoriloníticos e que todas as amostras apresentaram quartzo em sua composição. 
Os resultados encontrados para a análise de DRX estão dentro dos padrões relatados por Souza Santos em seus estudos sobre bentonitas (SOUZA, 1976), Amorim (2003), Pereira (2008) e Valenzuela-Diaz (1994).

\subsubsection{Análise Termogravimétrica (TG) e Análise Térmica Diferencial (DTA)}

As figuras 39 de (a) a (e) mostram as curvas DTA (análise térmica diferencial) e TG (análise termogravimétrica) para a amostra .

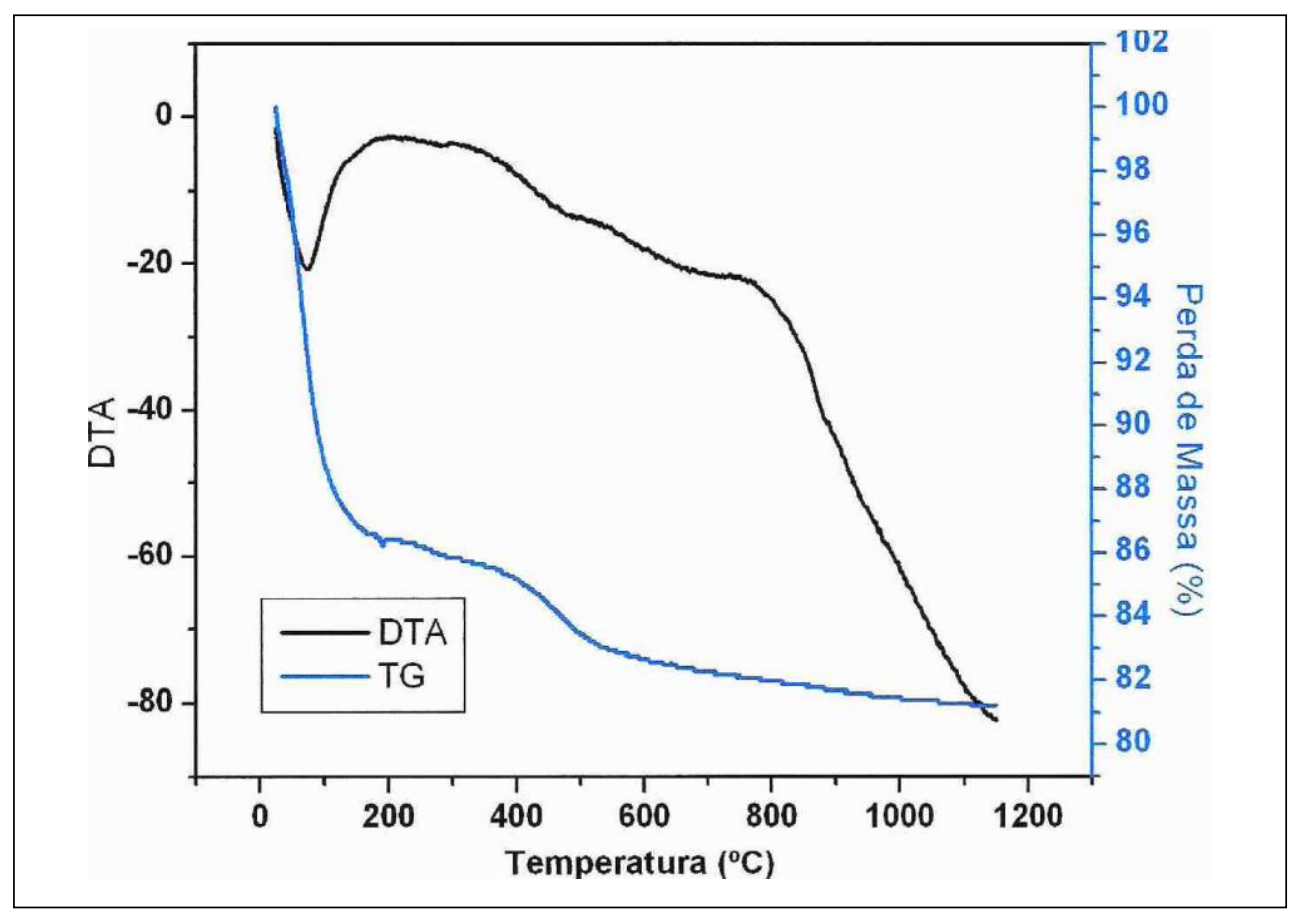

(a)Chocolate Lages 


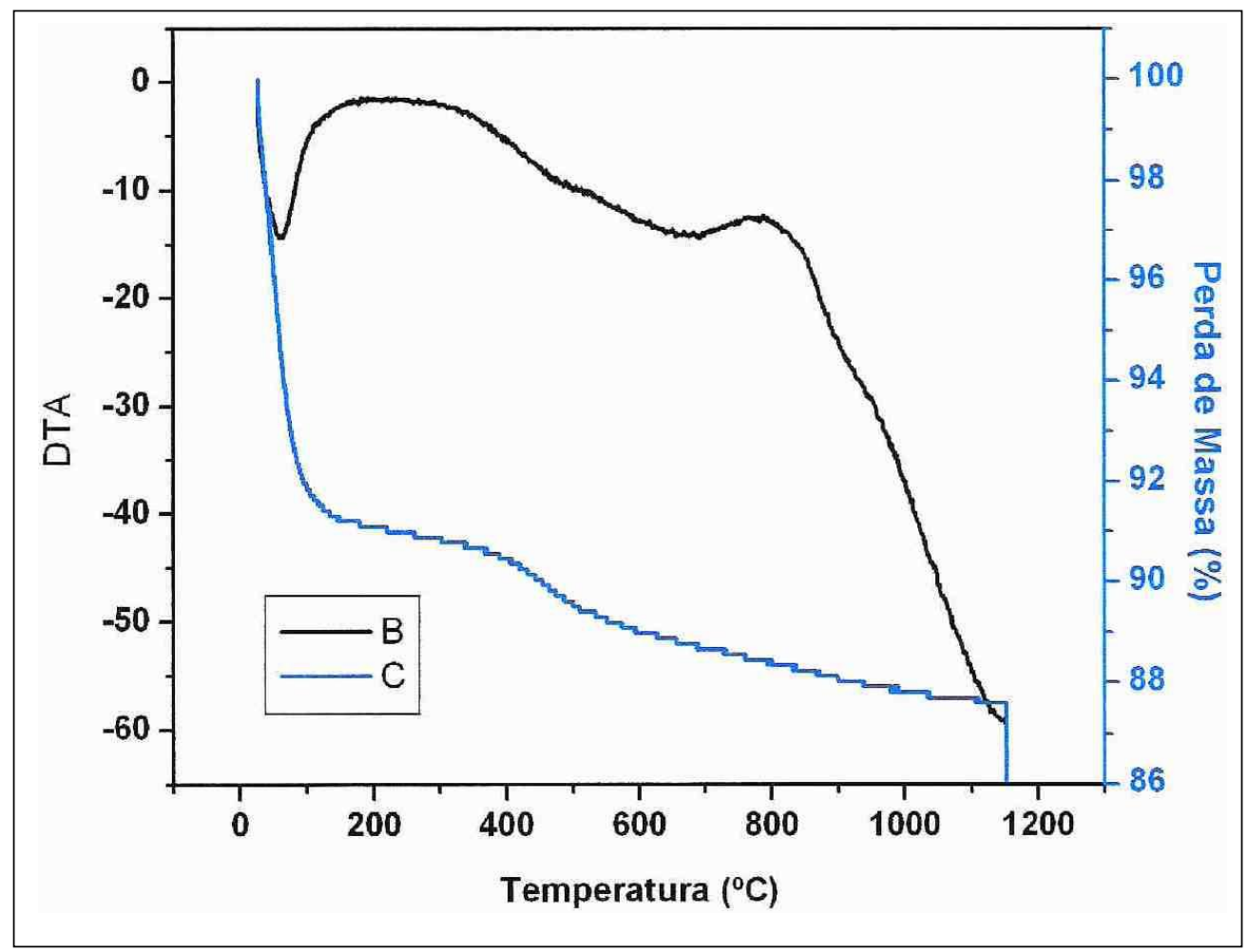

(b) Bofe Lages

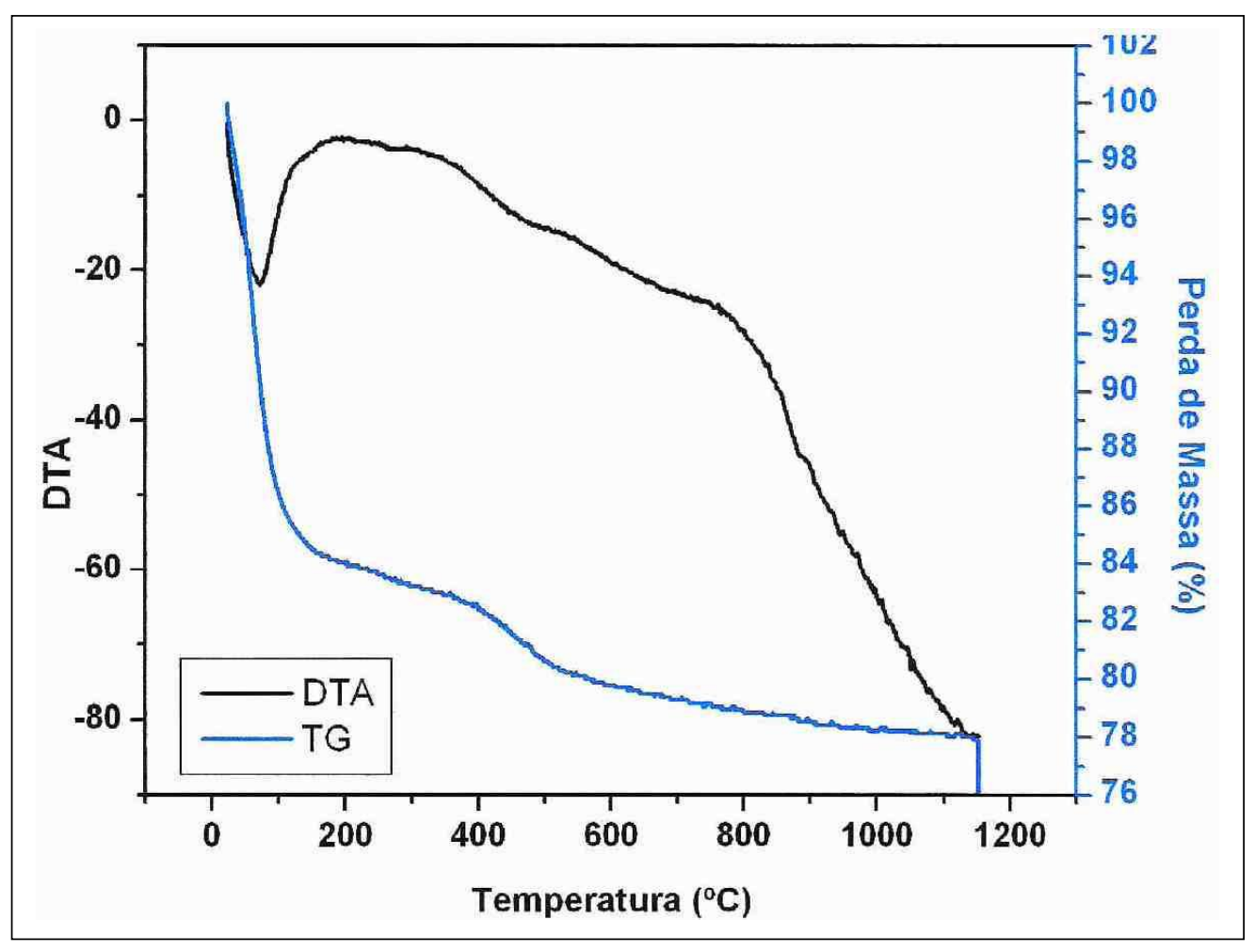

(c) Chocobofe Lages 


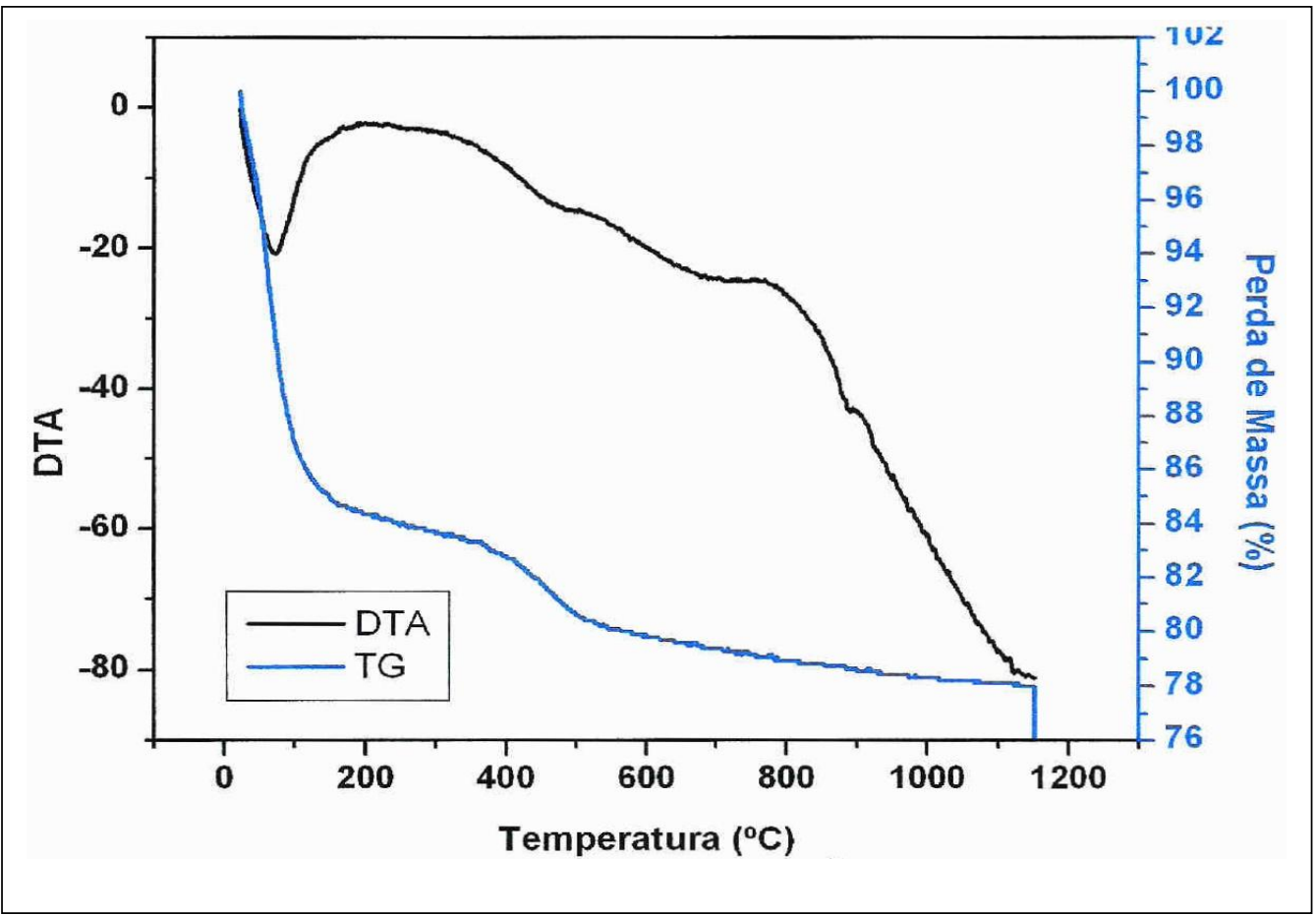

(d) Sortida Lages

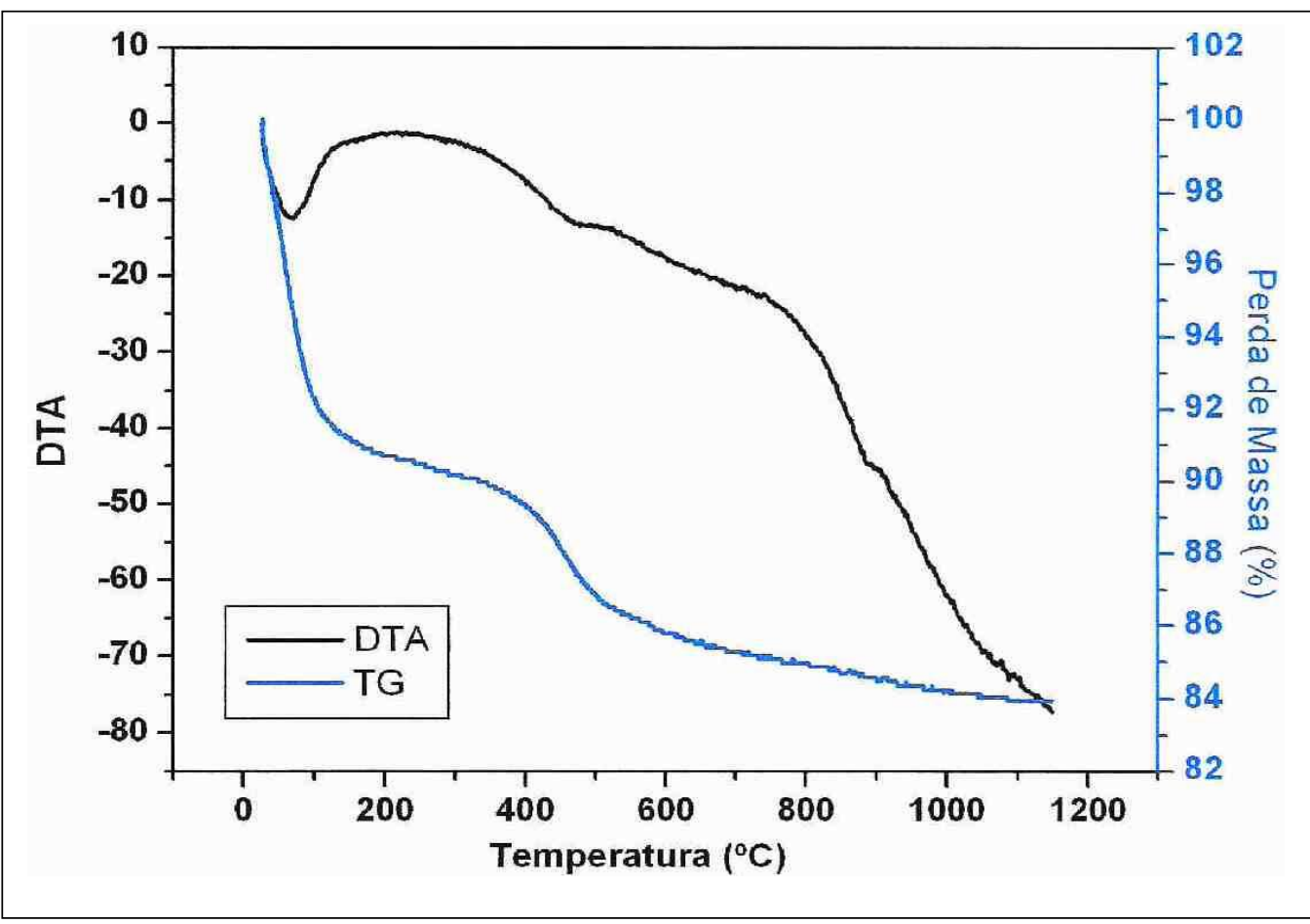

(e) Verde Lodo Lages

Figura 39: Curvas das análises térmicas das bentonitas da mina Lages: (a) Chocolate; (b) Bofe; (c) Chocobofe; (d) Sortida; (e) Verde Lodo. 
Através da figura 39, encontram-se as curvas das análises térmicas das bentonitas consideradas "in natura": Chocolate; Bofe; Chocobofe; Sortida e Verde Lodo. E na tabela 15 estão apresentados de forma resumida os resultados referentes à presença de $\mathrm{H}_{2} \mathrm{O}$ livre e desidroxilação.

Tabela 15: Resultados referentes as curvas de análises térmicas.

\begin{tabular}{|c|c|c|c|c|}
\hline Argilas & $\begin{array}{r}T_{i} \\
\text { Prese }\end{array}$ & Presença de $\mathrm{H}_{2} \mathrm{O}$ livre & Desidroxilação & $\begin{array}{l}T_{f} \\
\text { ção }\end{array}$ \\
\hline $\begin{array}{l}\text { Chocolate } \\
\text { Lages }\end{array}$ & 40 & 165 & 406 & 580 \\
\hline Bofe Lages & 29 & 135 & 411 & 547 \\
\hline $\begin{array}{l}\text { Chocobofe } \\
\text { Lages }\end{array}$ & 35 & 169 & 370 & 524 \\
\hline Sortida & 12 & 153 & 360 & 514 \\
\hline $\begin{array}{l}\text { Verde } \\
\text { Lodo Lages }\end{array}$ & 20 & 147 & 381 & 526 \\
\hline
\end{tabular}

Ao observar as curvas das análises térmicas foi possível verificar que:

(a) Através da curva termodiferencial para a bentonita Chocolate Lages "in natura", observou-se as seguintes transformações térmicas: uma banda endotérmica que ocorre entre $40^{\circ} \mathrm{C}$ e $165^{\circ} \mathrm{C}$, característico da perda de água livre, e uma banda endotérmica entre $406^{\circ} \mathrm{C}$ e $580^{\circ} \mathrm{C}$, causado pela perda de hidroxilas estruturais. Não foi possível, através dessas curvas, identificar a banda exotérmica estrutural ao qual se refere geralmente à destruição da estrutura da montmorilonita. Através da curva termogravimétrica, observou-se que o teor de água livre perdida para a argila foi de aproximadamente $14 \%$.

(b) Através da curva termodiferencial para a bentonita Bofe Lages "in natura", observou-se as seguintes transformações térmicas: uma banda endotérmica que ocorre entre $29{ }^{\circ} \mathrm{C}$ e $135^{\circ} \mathrm{C}$, característico da perda de água livre, e uma banda endotérmica entre $411^{\circ} \mathrm{C}$ e $547^{\circ} \mathrm{C}$, causado pela perda de hidroxilas estruturais. Não foi possível, através dessas curvas, identificar a banda exotérmica estrutural ao qual se refere geralmente à destruição da estrutura da montmorilonita. Através da curva termogravimétrica, observou-se que o teor de água livre perdida para a argila foi de aproximadamente $9 \%$. 
(c) Através da curva termodiferencial para a bentonita Chocobofe Lages "in natura", observou-se as seguintes transformações térmicas: uma banda endotérmica que ocorre entre $35^{\circ} \mathrm{C}$ e $169^{\circ} \mathrm{C}$, característico da perda de água livre, e uma banda endotérmica entre $370 \stackrel{\circ}{\circ}$ e $524^{\circ} \mathrm{C}$, causado pela perda de hidroxilas estruturais. Não foi possível, através dessas curvas, identificar a banda exotérmica estrutural ao qual se refere geralmente à destruição da estrutura da montmorilonita. Através da curva termogravimétrica, observou-se que o teor de água livre perdida para a argila foi de aproximadamente $16 \%$.

(d) Através da curva termodiferencial para a bentonita Sortida Lages "in natura" observou-se as seguintes transformações térmicas: uma banda endotérmica que ocorre entre $12^{\circ} \mathrm{C}$ e $153^{\circ} \mathrm{C}$, característico da perda de água livre, e uma banda endotérmica entre $360^{\circ} \mathrm{C}$ e $514^{\circ} \mathrm{C}$, causado pela perda de hidroxilas estruturais. Não foi possível, através dessas curvas, identificar a banda exotérmica estrutural ao qual se refere geralmente à destruição da estrutura da montmorilonita. Através da curva termogravimétrica, observou-se que o teor de água livre perdida para a argila foi de aproximadamente $16 \%$.

(e) Através da curva termodiferencial para a bentonita Verde Lodo Lages "in natura" observou-se as seguintes transformações térmicas: uma banda endotérmica que ocorre entre $20^{\circ} \mathrm{C}$ e $147^{\circ} \mathrm{C}$, característico da perda de água livre, e uma banda endotérmica entre $381^{\circ} \mathrm{C}$ e $526 \stackrel{\circ}{\circ}$, causado pela perda de hidroxilas estruturais. Não foi possível, através dessas curvas, identificar a banda exotérmica estrutural ao qual se refere geralmente à destruição da estrutura da montmorilonita. Através da curva termogravimétrica, observou-se que o teor de água livre perdida para a argila foi de aproximadamente $9 \%$.

Em resumo, analisando conjuntamente os resultados das bentonitas naturais acima foi possível verificar termogramas bastante semelhantes e que todas as amostras apresentaram um perfil de curva característico das argilas contendo argilominerais do grupo montmorilonitas. Pode-se observar uma perda de massa de variando de 9-16\%. Em geral a 30-150 C há uma banda endotérmica de perda de água adsorvida. A 400-540 C existe uma banda endotérmica, sendo descrito pela baixa intensidade, caracterizando a desidroxilação da amostra rica em ferro, teores estes que serão confirmados através dos resultados da análise química. Em todas as amostras, não foi possível, através dessas curvas, identificar a banda exotérmica estrutural ao qual se refere geralmente à destruição da estrutura da montmorilonita. 
Estes resultados encontram-se dentro dos padrões relatados por Souza Santos em seus estudos (SOUZA, 1976), Amorim (2003), Pereira (2008).

\subsubsection{Microscopia Eletrônica de Varredura (MEV)}

A morfologia das argilas pode ser observada através da Figura 40.

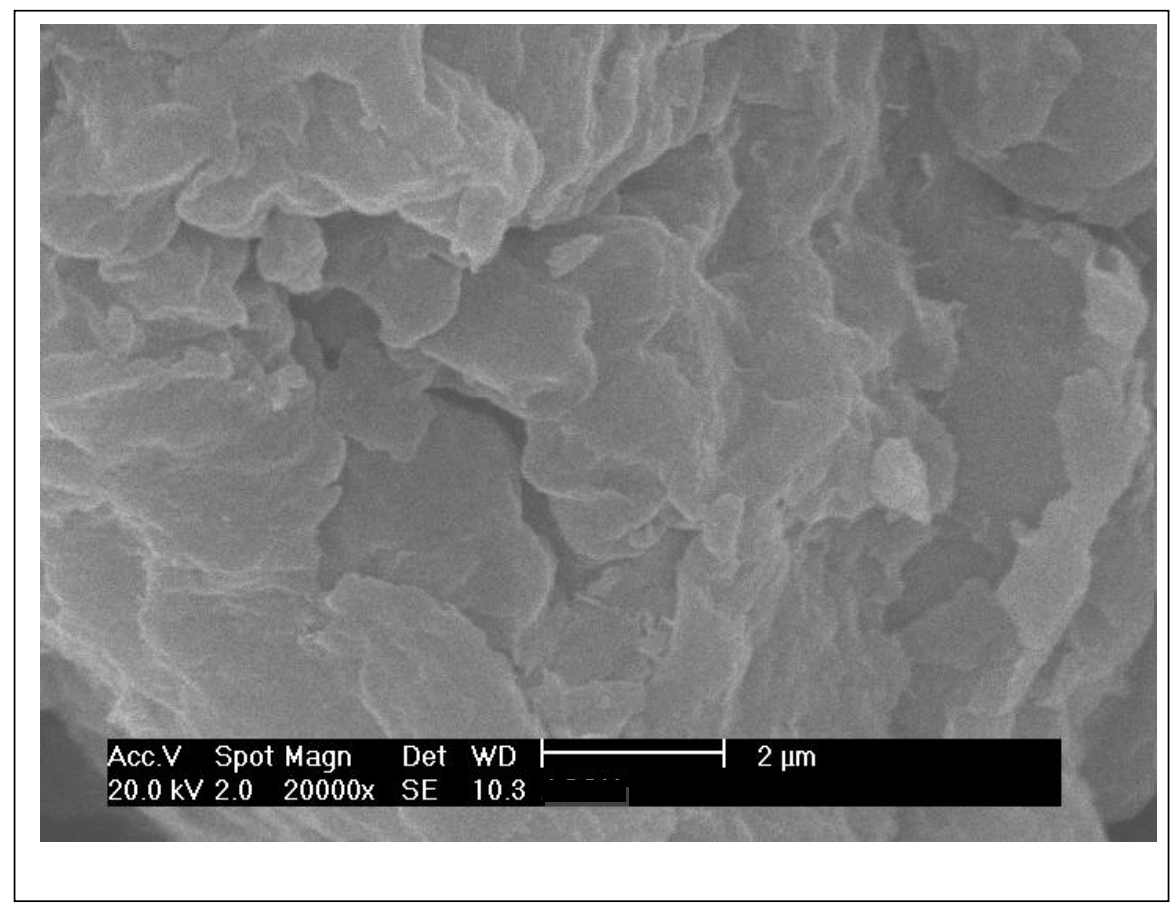

(a)Chocolate Lages

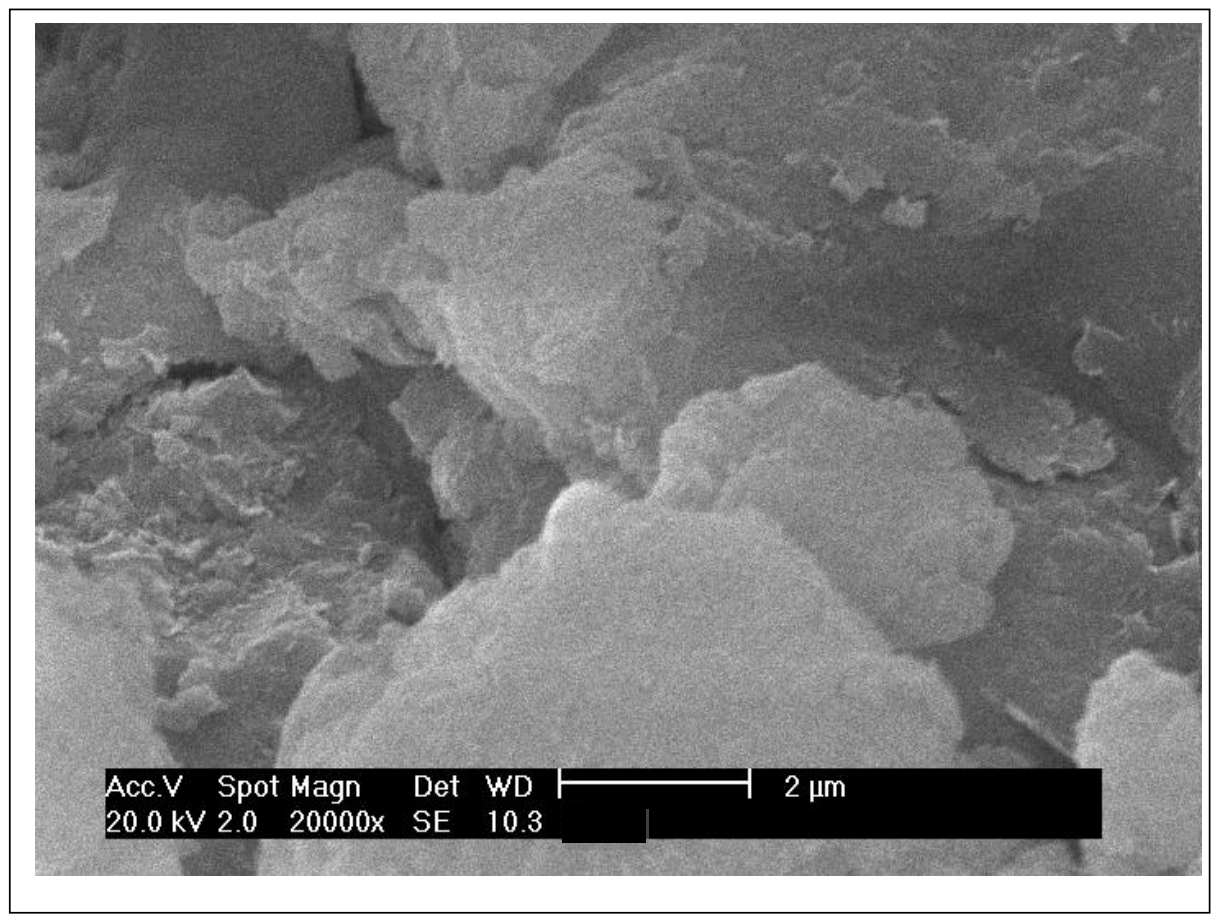

(b) Bofe Lages 


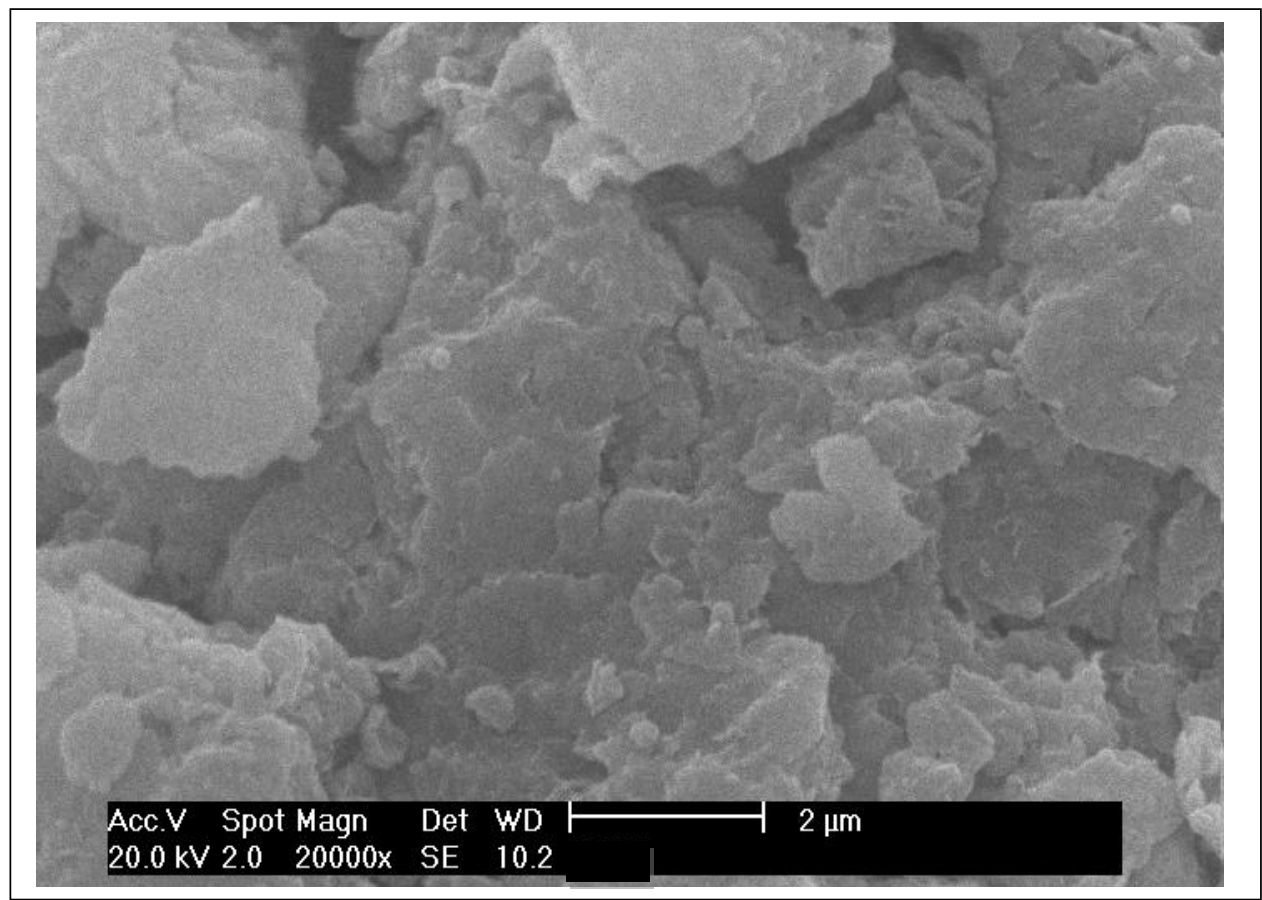

(c) Chocobofe Lages

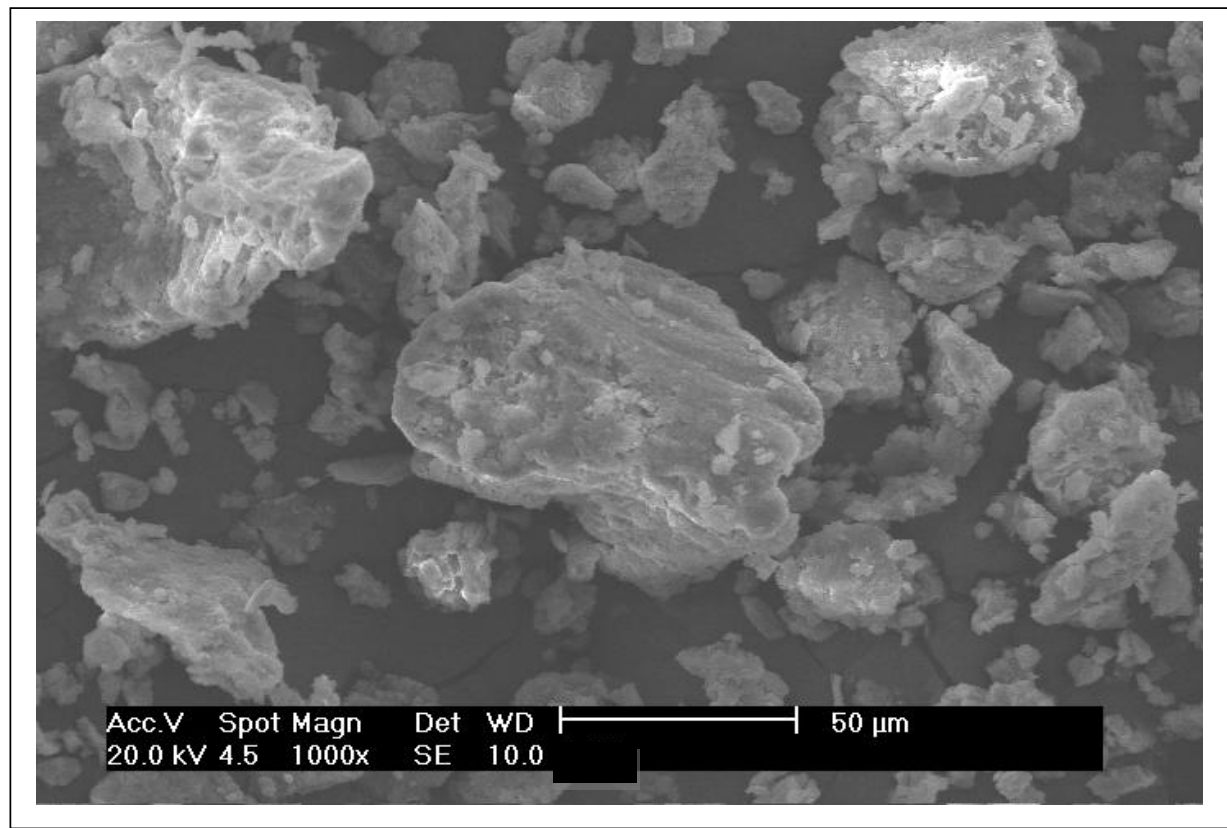

(d) Sortida Lages 


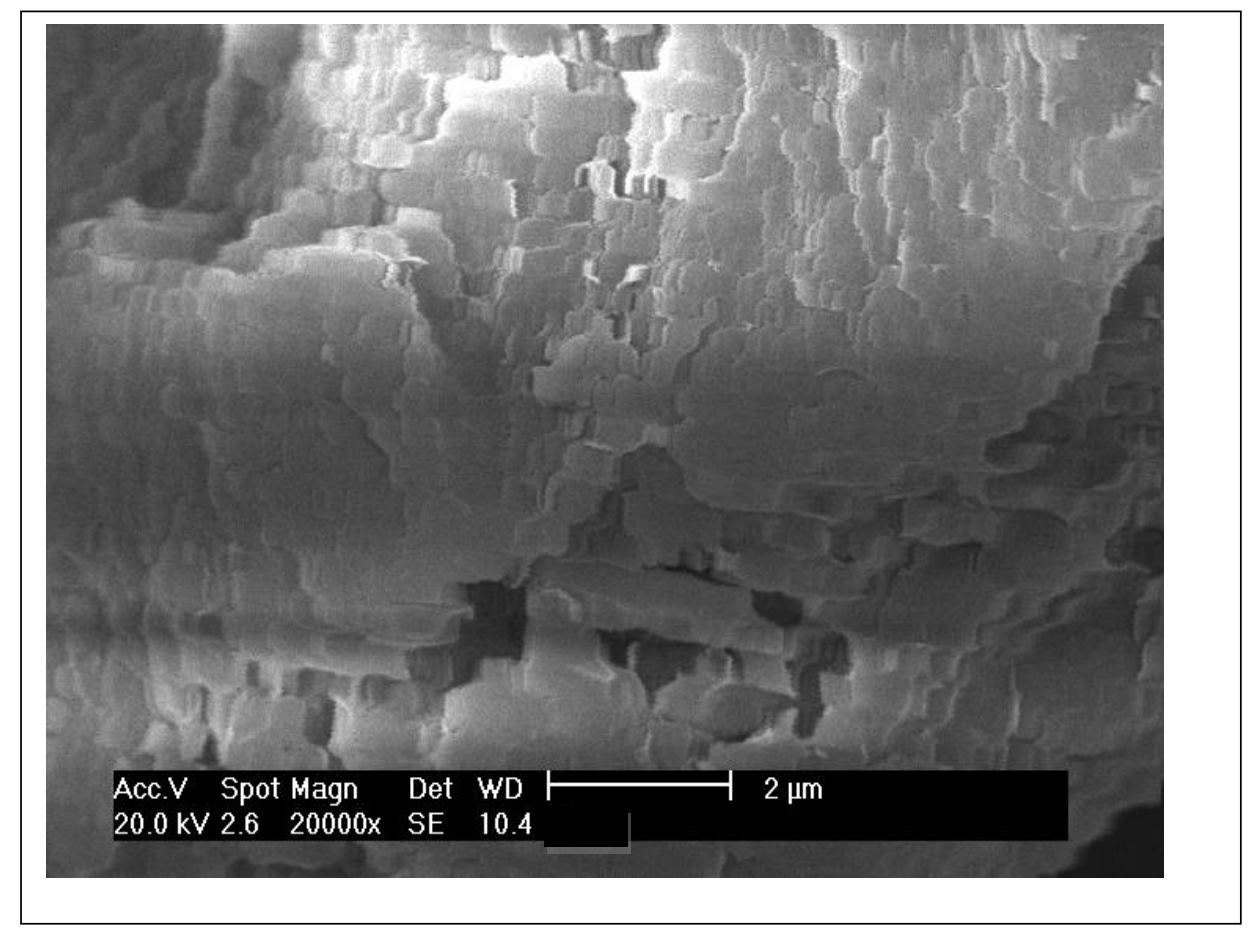

(e) Verde Lodo Lages

Figura 40: Micrografias eletrônicas de varredura das bentonitas da mina Lages: (a) Chocolate; (b) Bofe; (c) Chocobofe; (d) Sortida; (e) Verde Lodo, com aumentos de $20000 \mathrm{X}$.

Através da figura 40, encontram-se os MEVS das bentonitas consideradas "in natura": Chocolate; Bofe; Chocobofe; Sortida e Verde Lodo. Ressalta-se que as argilas Chocolate; Bofe; Chocobofe e Verde Lodo foram submetidas a 20000X de aumento e a argila sortida foi submetida a um aumento 1000X. Na tabela 16 estão apresentados de forma resumida os resultados referentes à variação das dimensões dos aglomerados de partículas das argilas.

Tabela 16: Variação das dimensões dos aglomerados de partículas das argilas.

\begin{tabular}{cc} 
Amostra & $\begin{array}{c}\text { Dimensões dos aglomerados de } \\
\text { partículas }\end{array}$ \\
\hline Chocolate & $0,63 \mu \mathrm{m}-5,79 \mu \mathrm{m}$ \\
Bofe & $0,5 \mu \mathrm{m}-8,4 \mu \mathrm{m}$ \\
Chocobofe & $0,5 \mu \mathrm{m}-3,6 \mu \mathrm{m}$ \\
\hline
\end{tabular}


Sortida

$8 \mu \mathrm{m}-70 \mu \mathrm{m}$

\section{Verde Lodo}

$0,63 \mu \mathrm{m}-6,11 \mu \mathrm{m}$

Ao observar as micrografias acima foi possível verificar que as partículas lamelares encontram-se empilhadas e aglomeradas, formando aglomerados de morfologia irregular, com contornos bem definidos e com dimensões variáveis e maiores que 0,53 $\mu \mathrm{m}$, concordando com o comportamento apresentado por Pereira (2008). Analisando cada amostra separadamente tem-se que:

(a) Para a bentonita Chocolate Lages "in natura", pode-se observar as partículas

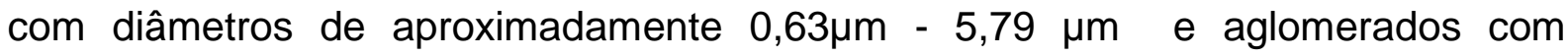
superfície mais ou menos lisa, onde não se distingue claramente a morfologia lamelar. Na imagem ampliada (20000X), mostrada na figura 40 (a), não é possível distinguir os contornos lamelares de partículas elementares.

(b) Para bentonita Bofe Lages "in natura", pode-se observar as partículas com diâmetros de aproximadamente 0,5 $\mu \mathrm{m}$ - 8,4 $\mu \mathrm{m}$ e aglomerados com superfície mais ou menos lisa, onde não se distingue claramente a morfologia lamelar. $\mathrm{Na}$ imagem ampliada (20000X), mostrada na figura 40 (b), não é possível distinguir os contornos lamelares de partículas elementares.

(c) Para a bentonita Chocobofe Lages "in natura”, pode-se observar as partículas com diâmetros de aproximadamente 0,5 $\mu \mathrm{m}$ - 3,6 $\mu \mathrm{m}$ e aglomerados com superfície mais ou menos lisa, onde não se distingue claramente a morfologia lamelar. $\mathrm{Na}$ imagem ampliada (20000X), mostrada na figura 40 (c), não é possível distinguir os contornos lamelares de partículas elementares .

(d) Para a bentonita Sortida Lages "in natura", pode-se observar as partículas com diâmetros de aproximadamente $8 \mu \mathrm{m}$ - $70 \mu \mathrm{m}$ e aglomerados com superfície mais ou menos lisa, onde não se distingue claramente a morfologia lamelar. A imagem foi ampliada (1000X).

(e) Para a bentonita Verde Lodo Lages "in natura”, pode-se observar as partículas com diâmetros de aproximadamente $0,63 \mu \mathrm{m}-6,11 \mu \mathrm{m}$ e aglomerados com superfície mais ou menos lisa, onde não se distingue claramente a morfologia lamelar. Na imagem ampliada (20000X), mostrada na figura 40 (e), não é possível distinguir os contornos lamelares de partículas elementares. 
De forma geral, a partir de observações diretas das microscopias eletrônicas de varredura (figura 40), foi possível verificar que todas as amostras de bentonitas apresentam morfologias similares. Portanto, observa-se que não há uma distribuição muito homogênea de partículas, pois apresentam grãos de diversos tamanhos, ocasionando, portanto, uma distribuição de partículas irregular. Observa-se ainda que essas amostras são constituídas por aglomerados de perfil irregular. Verifica-se a morfologia lamelar das camadas que formam as partículas elementares, formados pelo empilhamento dessas partículas lamelares (tactóides). E através da análise dos dados da tabela 16, podemos verificar que as amostras de bentonitas apresentaram uma distribuição média de partículas $0,5 \mu \mathrm{m}-8,4 \mu \mathrm{m}$, exceto para argila Sortida.

Estes resultados encontram-se dentro dos padrões relatados por Souza Santos em seus estudos (SOUZA, 1992) e Pereira (2008).

\subsubsection{Espectroscopia por Energia Dispersiva (EDS)}

No mesmo microscópio onde foram realizadas as microscopias eletrônicas de varredura para as bentonitas consideradas "in natura": Chocolate; Bofe; Chocobofe; Sortida e Verde Lodo, foram realizadas análises para a identificação dos elementos químicos presentes através do acessório de EDS anexado ao equipamento.

A figura 41 apresenta os resultados obtidos para essas amostras.

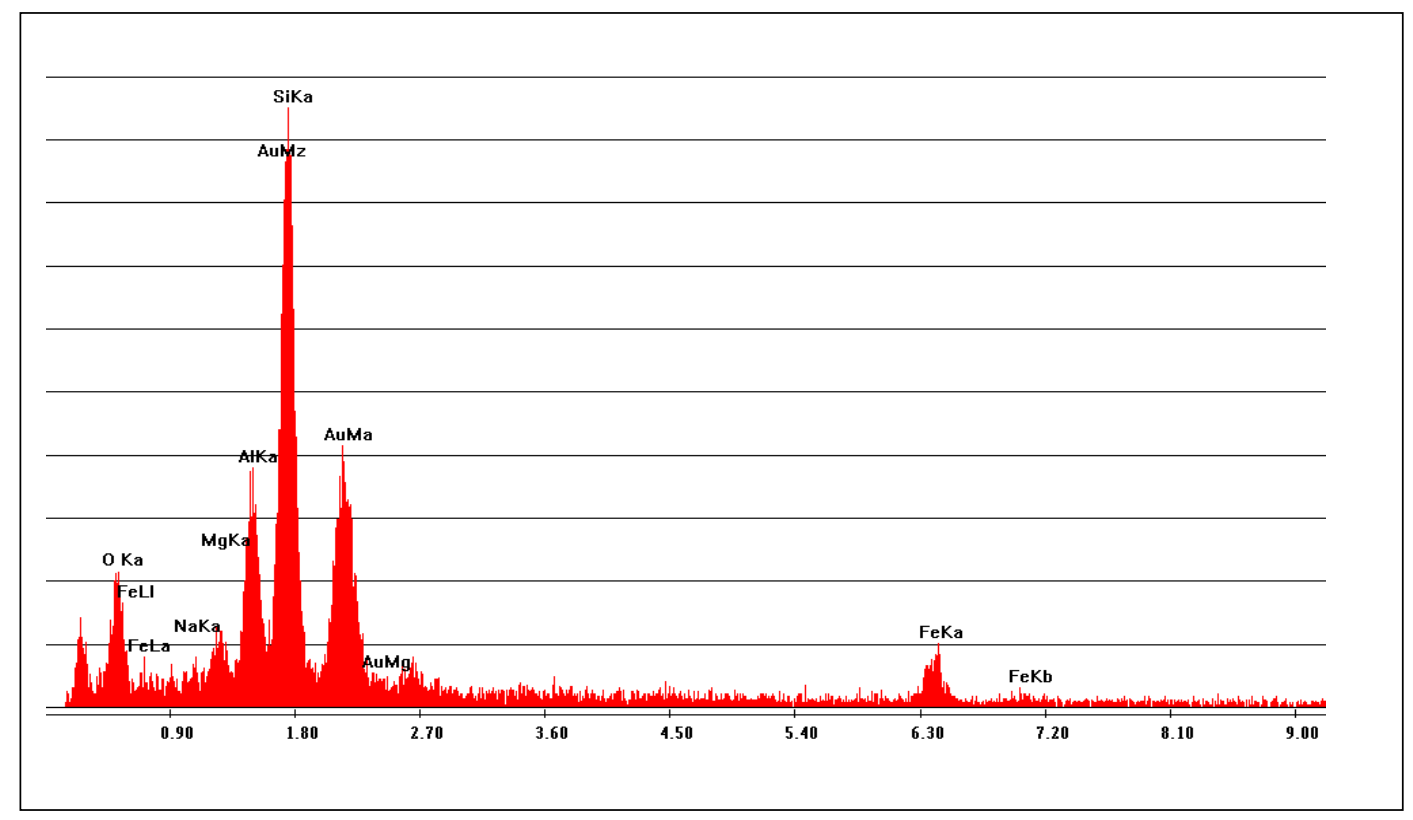

(a) Chocolate Lages 


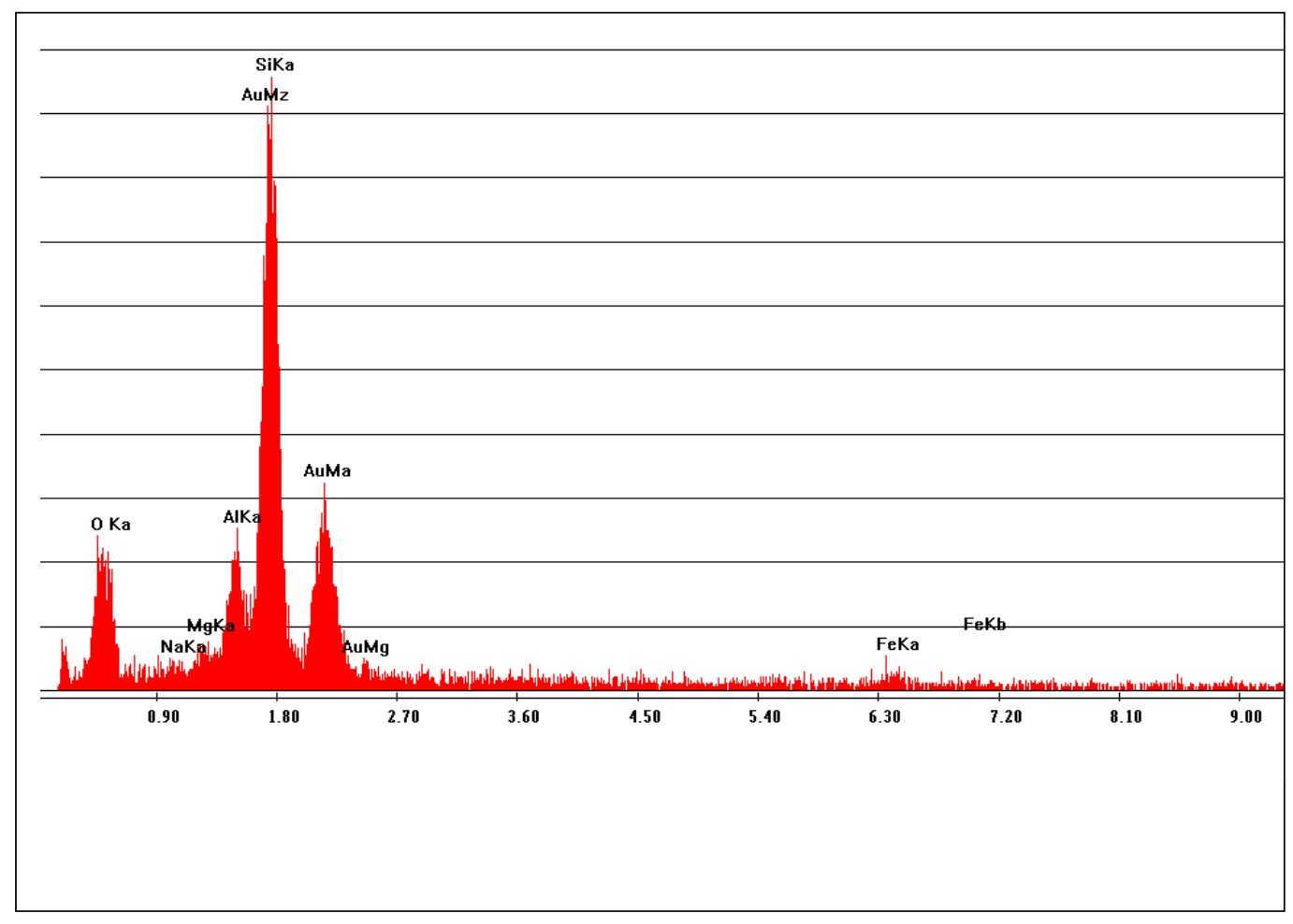

(b) Bofe Lages

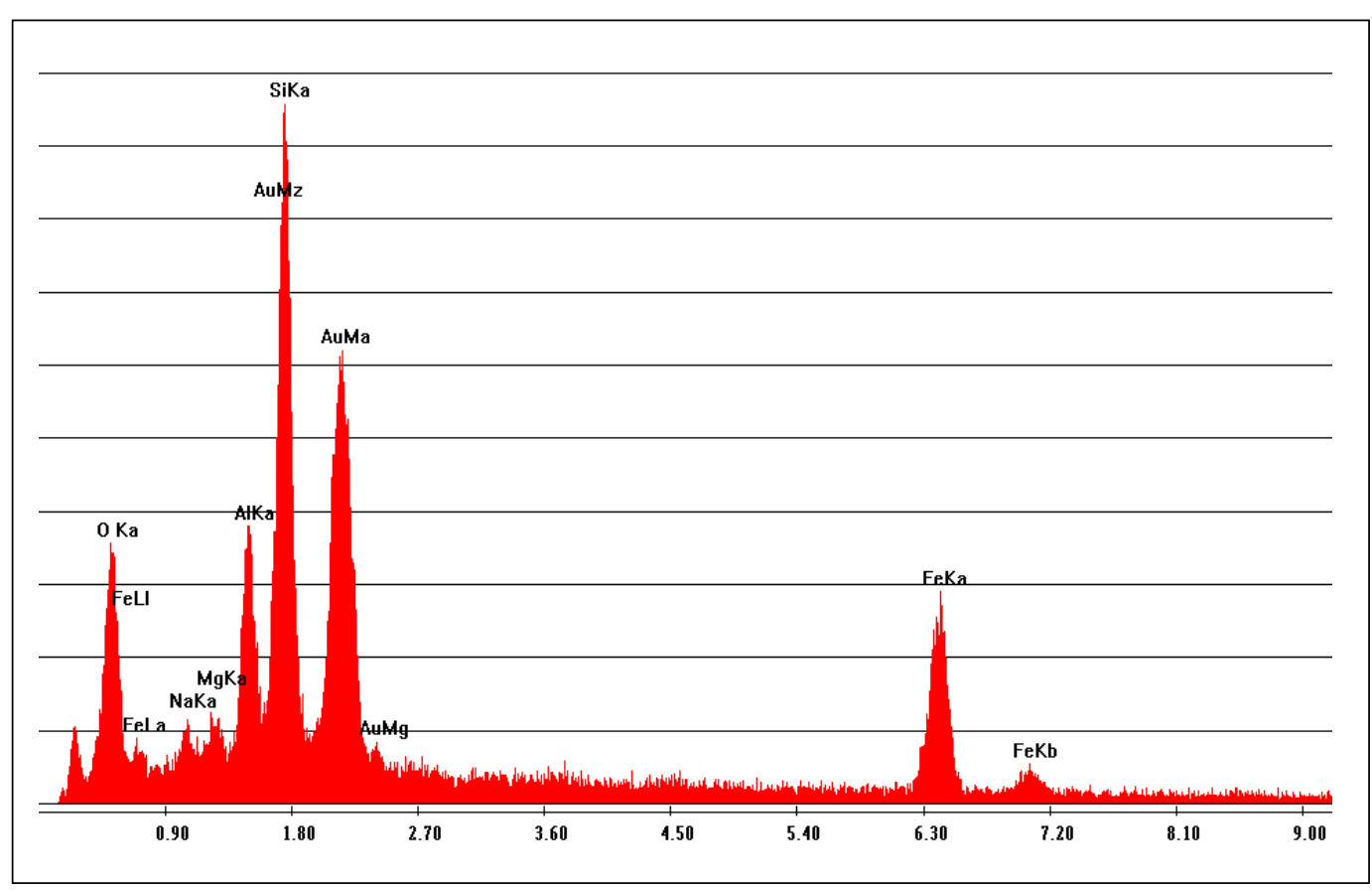

(c) Chocobofe Lages 


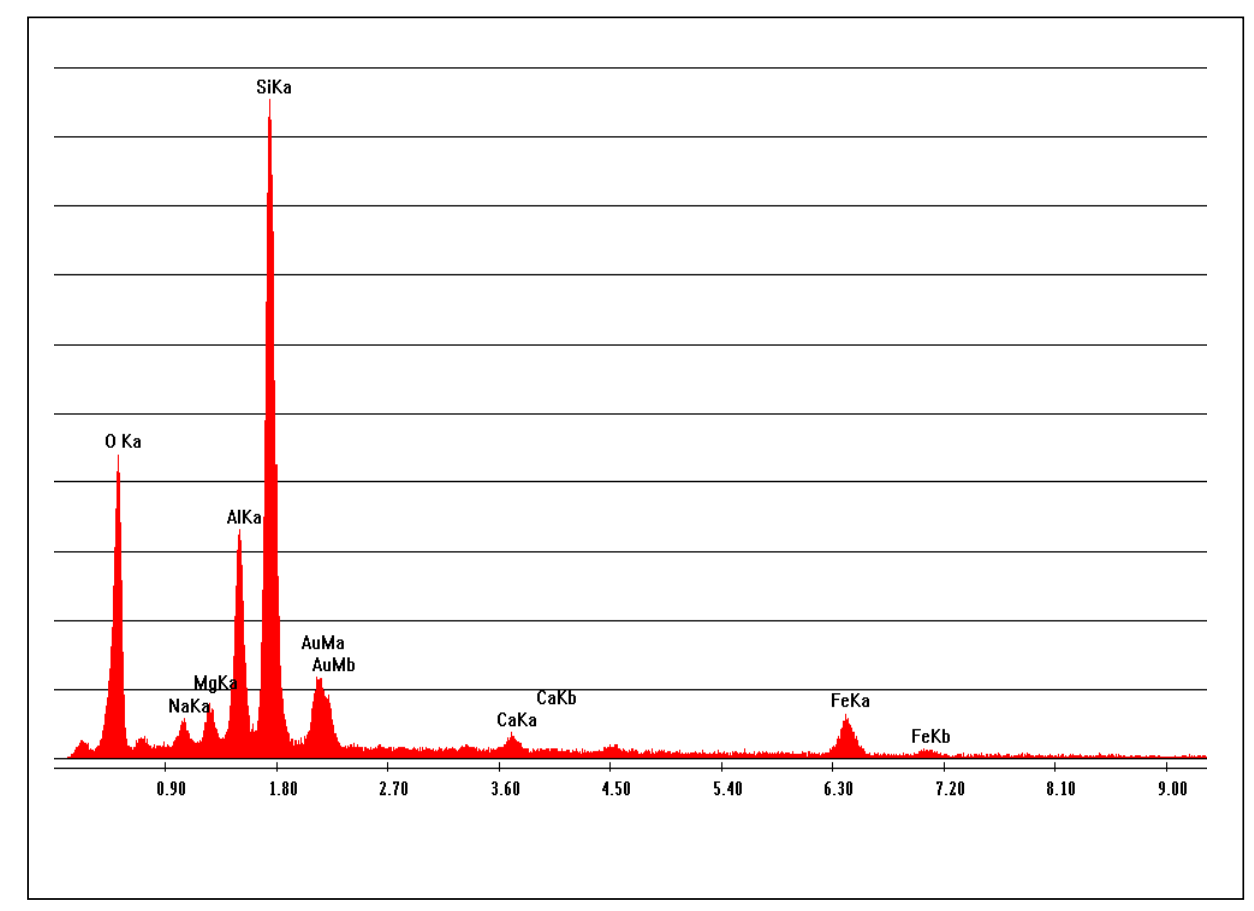

(d) Sortida Lages

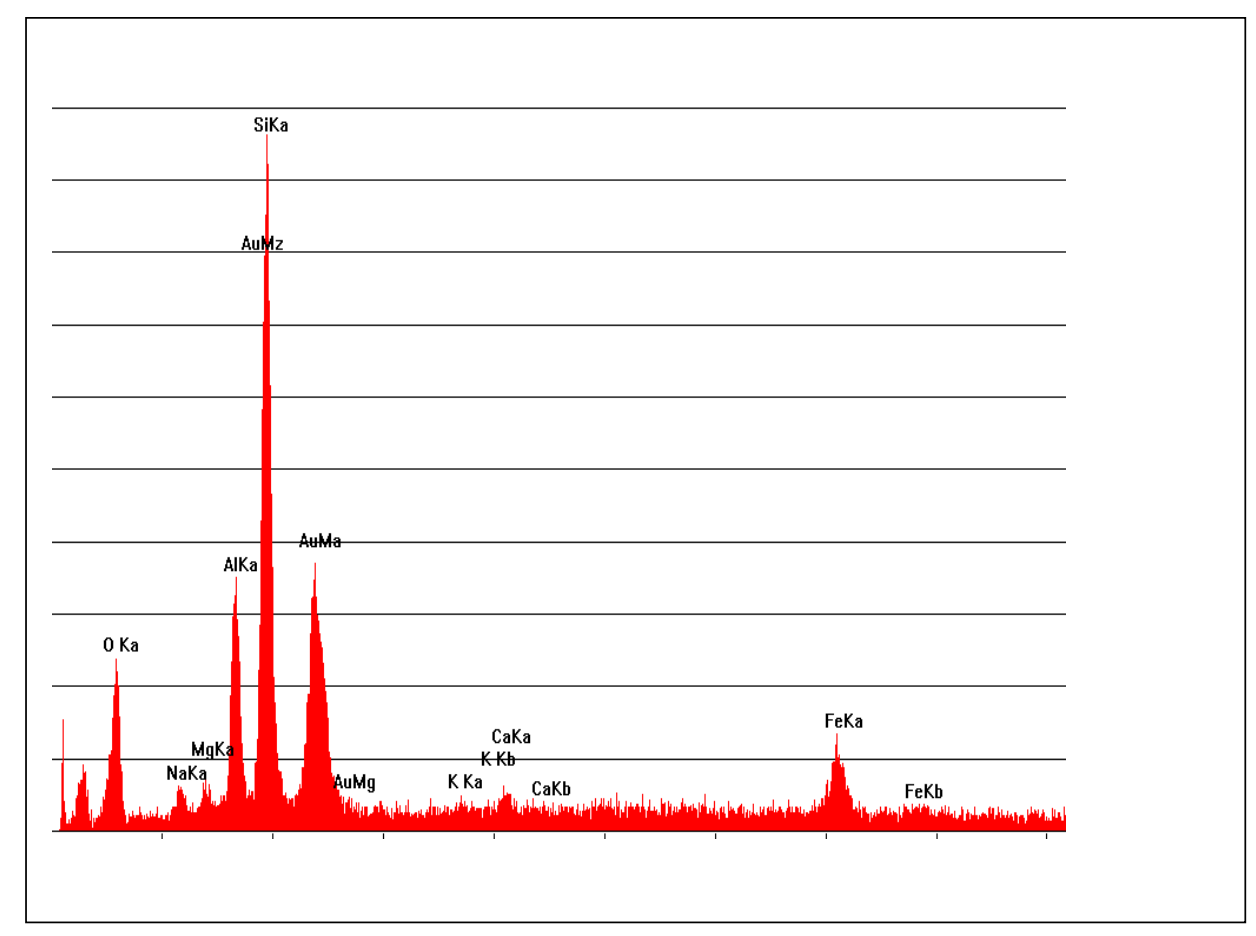

(e) Verde Lodo Lages

Figura 41: Espectroscopia por energia dispersiva das bentonitas da mina Lages: (a) Chocolate; (b) Bofe; (c) Chocobofe; (d) Sortida; (e) Verde Lodo. 
Através da análise de EDS verificou-se que as amostras de argila em estudo apresentam em sua composição basicamente Si e Al, característicos de bentonitas da Paraíba, traços de $\mathrm{Na}, \mathrm{Mg}$ e Ca; apresentam também em sua composição o Fe. A presença do Au deve-se ao recobrimento da argila a qual possibilitou a realização desta análise. A composição química quantitativa e mais detalhada será possível através do FRX.

\subsubsection{Espectroscopia na Região do Infravermelho (IV)}

Na figura 42 estão apresentadas as curvas de espectroscopias na região do infravermelho para as amostras de bentonitas consideradas "in natura": Chocolate; Bofe; Chocobofe; Sortida e Verde Lodo.

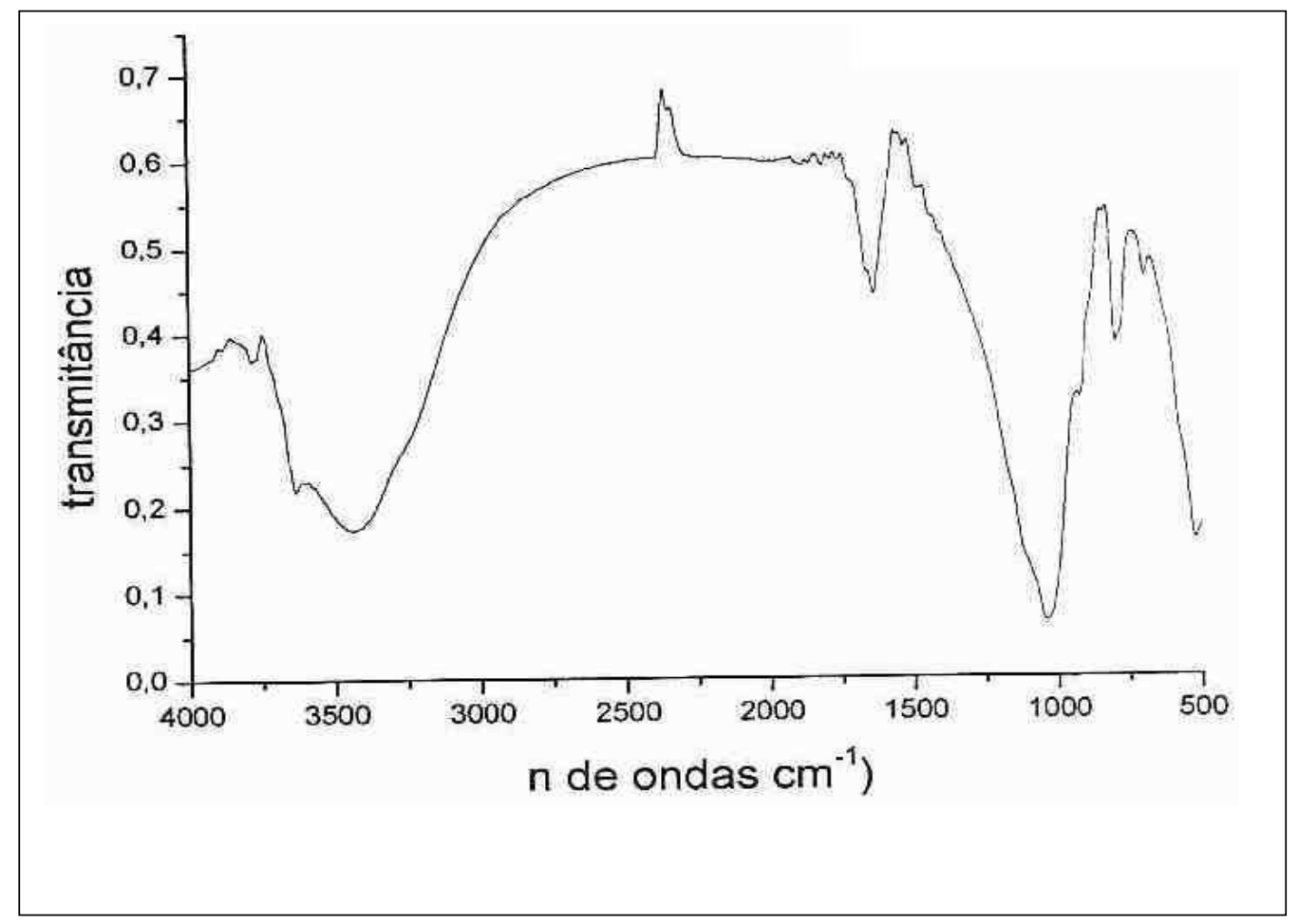

(a) Chocolate Lages 


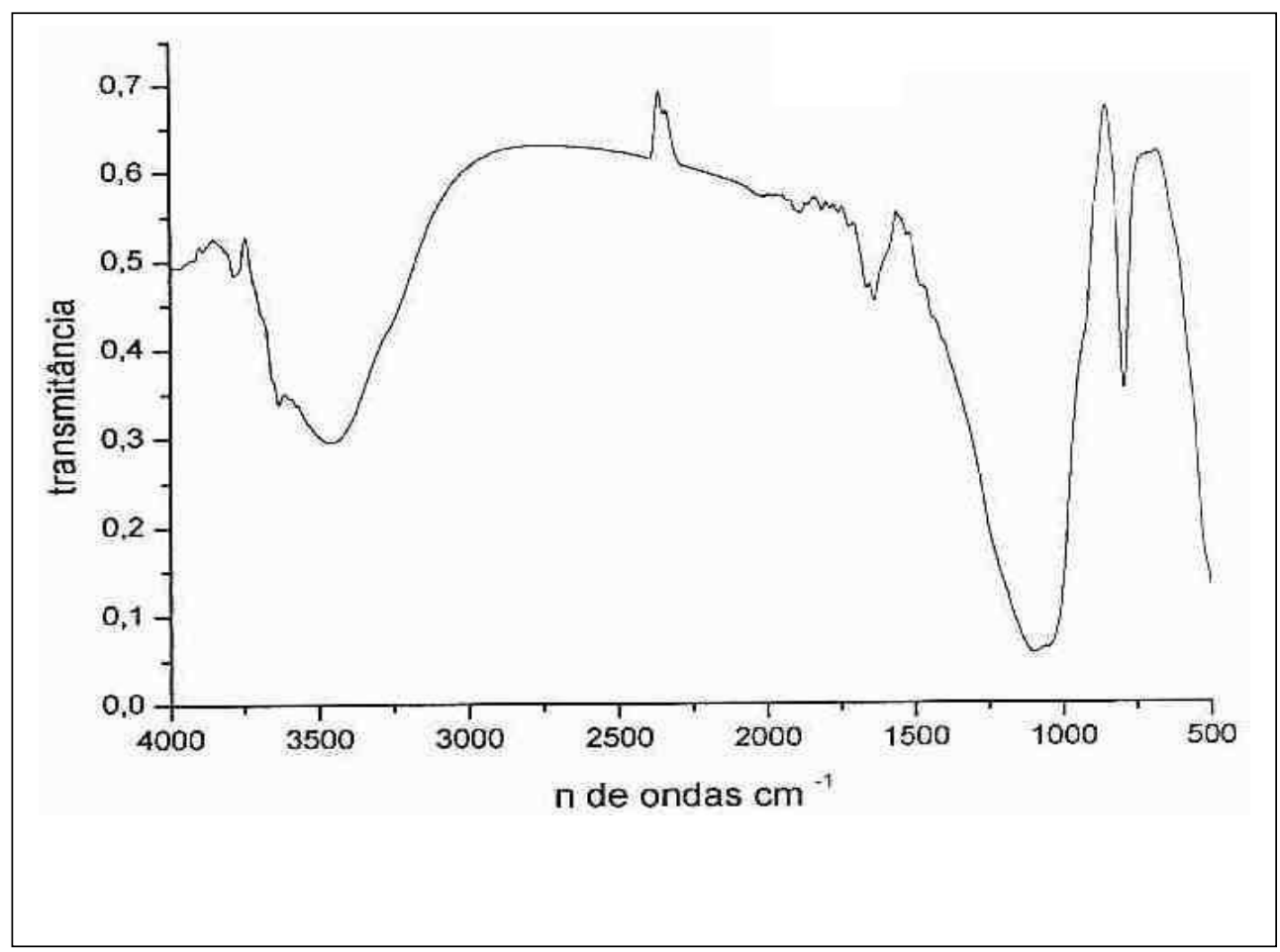

(b) Bofe Lages

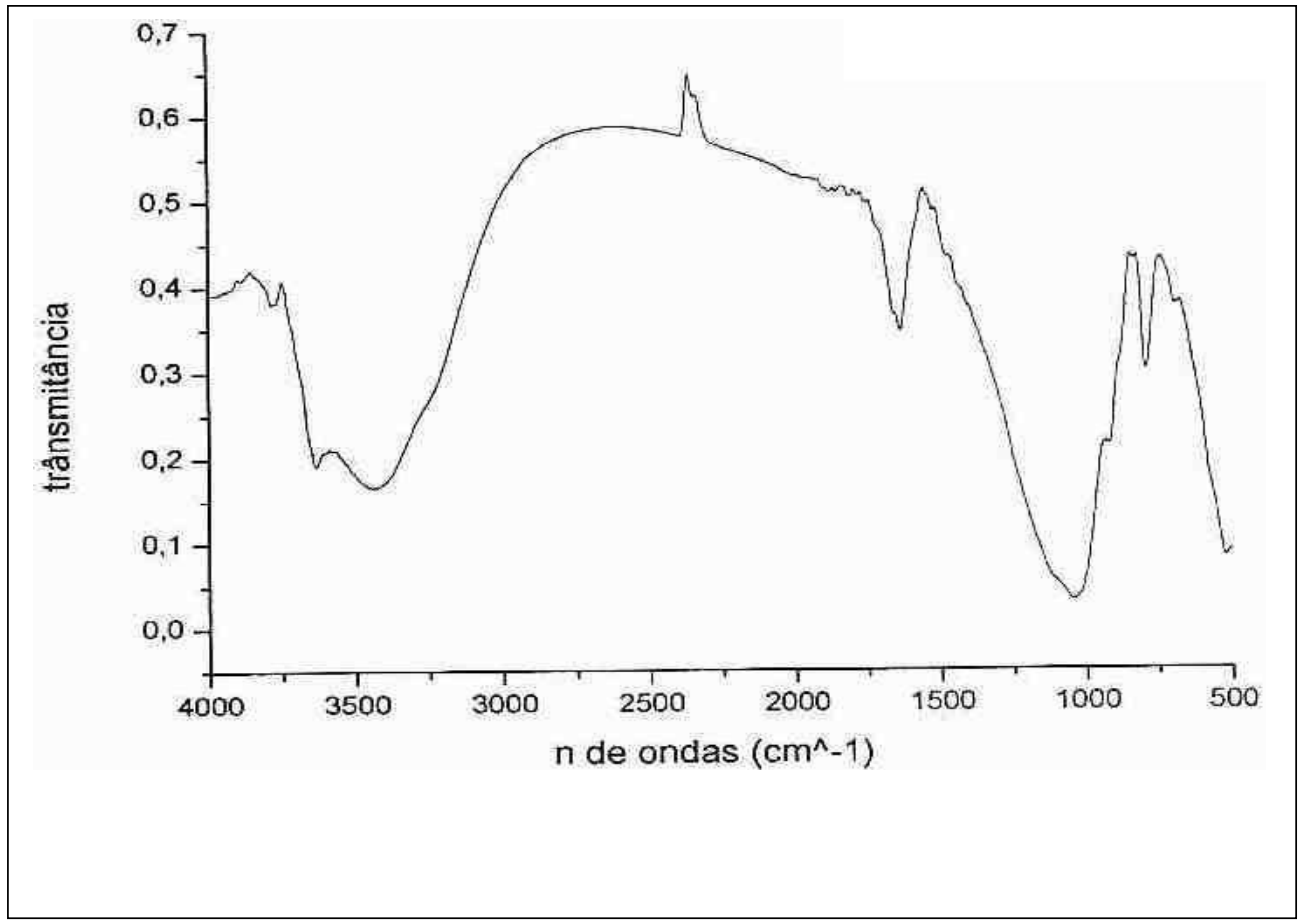

(c) Chocobofe Lages 


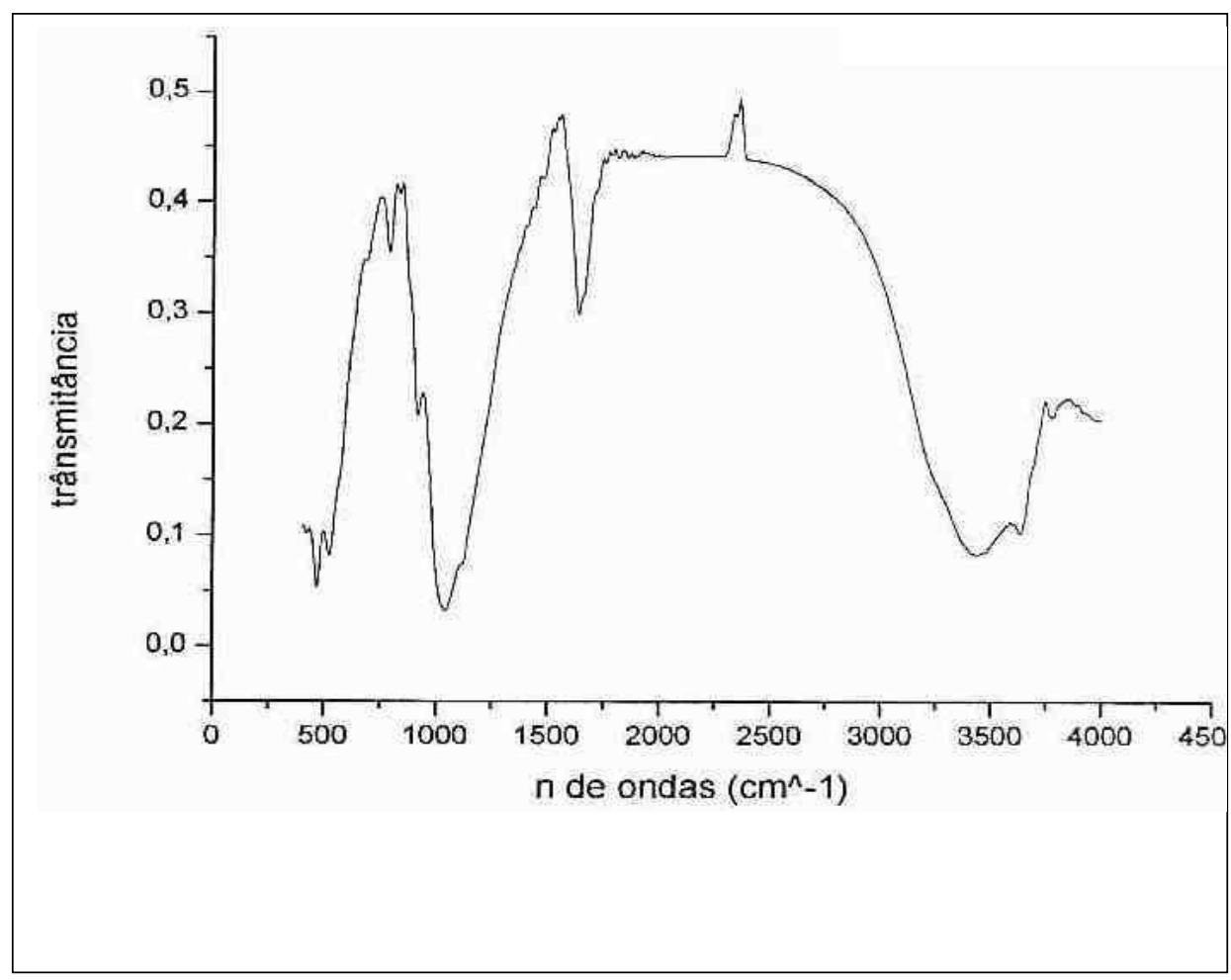

(d) Sortida Lages

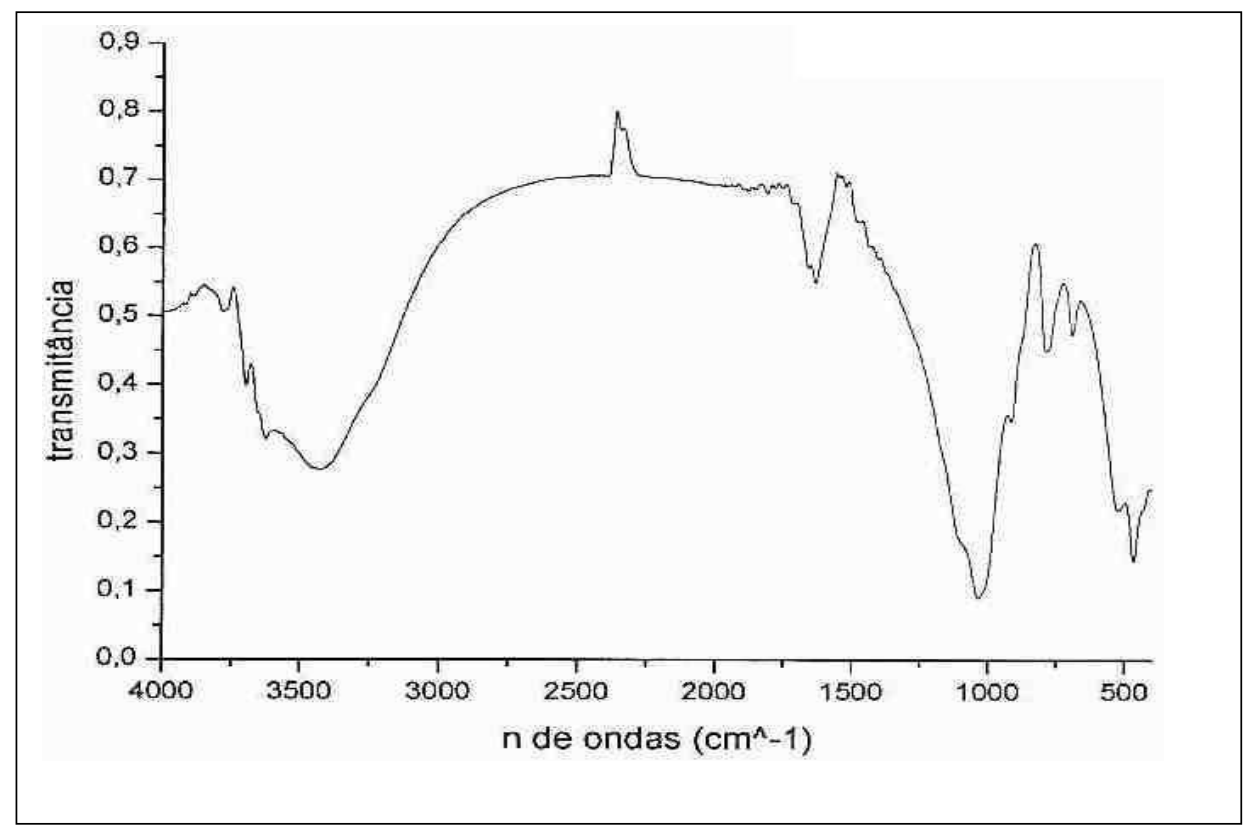

(e) Verde Lodo Lages

Figura 42: Curvas de infravermelho das bentonitas da mina Lages: (a) Chocolate;

(b) Bofe; (c) Chocobofe; (d) Sortida; (e) Verde Lodo. 
Através da observação da figura 42 podemos destacar que as amostras de bentonitas têm as seguintes absorções:

(a) Para a argila Chocolate Lages "in natura", a $3422 \mathrm{~cm}^{-1}$ banda característica da presença de hidroxilas; a $1625 \mathrm{~cm}^{-1}$ banda característica de água adsorvida; a 1031 $\mathrm{cm}^{-1}$ banda característica de ligações Si-O-Si, o que apenas vem a confirmar que esta amostra trata-se de uma bentonita .

(b) Para a argila Bofe Lages "in natura", $3453 \mathrm{~cm}^{-1}$ banda característica da presença de hidroxilas; a $1625 \mathrm{~cm}^{-1}$ banda característica de água adsorvida; a $1094 \mathrm{~cm}^{-1}$ banda característica de ligações $\mathrm{Si}-\mathrm{O}-\mathrm{Si}$, o que apenas vem a confirmar que esta amostra trata-se de uma bentonita .

(c) Para a argila Chocobofe Lages "in natura", $3453 \mathrm{~cm}^{-1}$ banda característica da presença de hidroxilas; a $1656 \mathrm{~cm}^{-1}$ banda característica de água adsorvida; a 1063 $\mathrm{cm}^{-1}$ banda característica de ligações Si-O-Si, o que apenas vem a confirmar que esta amostra trata-se de uma bentonita .

(d) Para a argila Sortida Lages "in natura", $3417 \mathrm{~cm}^{-1}$ banda característica da presença de hidroxilas; a $1646 \mathrm{~cm}^{-1}$ banda característica de água adsorvida; a 1042 $\mathrm{cm}^{-1}$ banda característica de ligações Si-O-Si, o que apenas vem a confirmar que esta amostra trata-se de uma bentonita.

(e) Para a argila Verde Lodo Lages "in natura", $3429 \mathrm{~cm}^{-1}$ banda característica da presença de hidroxilas; a $1625 \mathrm{~cm}^{-1}$ banda característica de água adsorvida; a 1032 $\mathrm{cm}^{-1}$ banda característica de ligações $\mathrm{Si}-\mathrm{O}-\mathrm{Si}$, o que apenas vem a confirmar que esta amostra trata-se de uma bentonita.

Em resumo, as amostras estudadas apresentaram espectros bastantes semelhantes, com bandas características da presença de hidroxilas, água adsorvida e de ligações Si-O-Si. Apresentando por tanto espectros praticamente dentro da mesma faixa de comprimento de onda. Comparando-se os espectros das amostras, não foi percebida praticamente nenhuma alteração nas posições das bandas características das mesmas, já que todas tratam-se de amostras de bentonitas oriundas da Paraíba. Estes resultados estão em conformidade com os DRX apresentados anteriormente. 
$\mathrm{Na}$ tabela 17 foram apresentados de forma resumida os valores para as seguintes absorções características: da presença de hidroxilas, de água adsorvida e das ligações Si-O-Si .

Tabela 17: Valores para as absorções características.

\begin{tabular}{|c|c|c|c|}
\hline ARGILA & $\begin{array}{c}\text { Banda } \\
\text { característica da } \\
\text { presença de } \\
\text { hidroxilas }\left(\mathrm{cm}^{-1}\right)\end{array}$ & $\begin{array}{c}\text { Banda característica } \\
\text { da presença de } \\
\text { água adsorvida } \\
\left(\mathrm{cm}^{-1}\right)\end{array}$ & $\begin{array}{c}\text { Banda } \\
\text { característica da } \\
\text { presença das } \\
\text { ligações Si-O-Si } \\
\left(\mathrm{cm}^{-1}\right)\end{array}$ \\
\hline CHOCOLATE & 3422 & 1625 & 1031 \\
\hline BOFE & 3453 & 1625 & 1094 \\
\hline CHOCOBOFE & 3453 & 1656 & 1063 \\
\hline SORTIDA & 3417 & 1646 & 1042 \\
\hline VERDE LODO & 3429 & 1625 & 1032 \\
\hline
\end{tabular}

Estes resultados encontram-se dentro das características relatadas por Amorim (2003) e Pereira (2008).

\subsubsection{Fluorescência de raios $X(F R X)$}

A análise por Fluorescência de raios $X$ foi empregada para se determinar à composição química das bentonitas em estudo. A tabela 18 mostra os resultados de análise química.

Tabela 18: Resultados de FRX para as bentonitas da mina Lages: (a) Chocolate; (b) Bofe; (c) Chocobofe; (d) Sortida; (e) Verde Lodo. 


\begin{tabular}{|c|c|c|c|c|c|}
\hline Argilas & Chocolate & Bofe & Chocobofe & Sortida & Verde Lodo \\
\hline $\mathrm{SiO}_{2}(\%)$ & 61,08 & 71,045 & 62,34 & 59,72 & 50,48 \\
\hline $\mathrm{Al}_{2} \mathrm{O}_{3}(\%)$ & 15,28 & 11,822 & 14,39 & 17,98 & 20,70 \\
\hline $\mathrm{Fe}_{2} \mathrm{O}_{3}(\%)$ & 10,19 & 6,273 & 11,18 & 8,78 & 12,46 \\
\hline $\mathrm{MgO}(\%)$ & 1,75 & 1,22 & 1,80 & 1,72 & 1,94 \\
\hline $\mathrm{Na}_{2} \mathrm{O}(\%)$ & - & 0,648 & - & - & - \\
\hline $\mathrm{CaO}(\%)$ & 1,58 & 0,697 & 1,50 & 1,25 & 1,07 \\
\hline $\mathrm{K}_{2} \mathrm{O}(\%)$ & 0,38 & 0,273 & 0,46 & 0,75 & 2,57 \\
\hline $\mathrm{SO}_{3}(\%)$ & 0,12 & - & 0,17 & 0,12 & 0,07 \\
\hline $\mathrm{P}_{2} \mathrm{O}_{5}(\%)$ & - & - & - & - & 0,07 \\
\hline $\mathrm{MnO}(\%)$ & - & - & - & - & 0,07 \\
\hline $\mathrm{TiO}_{2}(\%)$ & 0,92 & 0,70 & 0,95 & 1,25 & 1,47 \\
\hline $\mathrm{ZrO}_{2}(\%)$ & 0,01 & 0,013 & 0,02 & 0,03 & 0,03 \\
\hline $\mathrm{Sc}_{2} \mathrm{O}_{3}(\%)$ & - & - & 0,07 & - & - \\
\hline $\mathrm{V}_{2} \mathrm{O}_{5}(\%)$ & 0,06 & - & 0,60 & - & 0,21 \\
\hline $\mathrm{CuO}(\%)$ & 0,03 & 0,035 & - & 0,04 & 0,05 \\
\hline $\mathrm{NiO}(\%)$ & - & - & - & - & 0,02 \\
\hline $\mathrm{ZnO}(\%)$ & 0,02 & 0,015 & - & 0,02 & 0,03 \\
\hline $\mathrm{SrO}(\%)$ & 0,02 & - & 0,02 & 0,02 & 0,014 \\
\hline $\mathrm{Y}_{2} \mathrm{O}_{3}(\%)$ & & - & - & - & 0,02 \\
\hline $\mathrm{Cr}_{2} \mathrm{O}_{3}(\%)$ & 0,05 & - & - & - & 0,06 \\
\hline PF(\%) & 6,58 & 7,08 & 7,05 & 8,33 & 8,66 \\
\hline
\end{tabular}

Fazendo uma análise desses resultados foi possível observar que: os teores de óxidos mais elevados foram $\mathrm{SiO}_{2}$ e $\mathrm{Al}_{2} \mathrm{O}_{3}$, perfazendo assim mais de $75 \%$ de cada amostra, sendo provavelmente provenientes dos argilominerais e da sílica livre presente nas amostras de bentonitas, valores esses coerentes com a literatura (SOUZA SANTOS, 1992).

Quanto aos valores de $\mathrm{TiO}_{2}$, verificou-se que os mesmos encontraram-se variando entre 0,70 e $1,47 \%$, não devendo alterar significativamente as propriedades 
tecnológicas dessas argilas. Já os teores de $\mathrm{MnO}$ e $\mathrm{P}_{2} \mathrm{O}_{5}$ situaram-se abaixo de 0,07\% para todas as amostras, não devendo ter, também, influência significativa nas propriedades tecnológicas das argilas.

Pode-se observar ainda que as amostras apresentaram teores de $\mathrm{Na}_{2} \mathrm{O}$ na faixa de 0,64\%.O teor de óxido de cálcio variou entre 0,69\% para 1,58\%. A presença do cálcio em argilas montmoriloníticas ocorre geralmente na forma de cátion trocável.

Para as amostras estudadas observou-se ainda a presença de minerais de ferro com teores variando entre 6,27 - 12,46\%. Estes teores de $\mathrm{Fe}_{2} \mathrm{O}_{3}$, são típicos de argilas do município de Boa Vista-PB, são provavelmente provenientes do reticulado crisitalino da ilita, que contém cerca de 4,00\% a 6,00\% de $\mathrm{Fe}_{2} \mathrm{O}_{3}$, e dos argilominerais do grupo da esmectita, ou seja, montmorilonita ou membro da série isomórfica nontronita-beidelita, segundo dados de Souza Santos (1976).

As amostras apresentaram ainda teores de $\mathrm{MgO}$ variando entre 1,22\% para 1,94\%, não devendo ter, também, influência significativa nas propriedades tecnológicas das argilas, porém sabe-se que a presença desse óxido em teores elevados pode indicar aumento da viscosidade, uma vez que o magnésio confere as dispersões, estado parcialmente floculado.

Com relação ao teor de $\mathrm{K}_{2} \mathrm{O}$ houve uma variação de $0,27 \%$, para 2,57\%. Para Amorim (2003) a presença do K pode interferir no comportamento reológico de bentonitas, caso o processo de secagem das amostras seja realizado a temperaturas superiores a $60^{\circ} \mathrm{C}$. Ressalta-se ainda, que quando isto ocorre, a água interlamelar é expulsa e a argila pode adquirir a estrutura cristalina próxima à da mica muscovita. Sob essa condição, a penetração de água entre as camadas fica dificultada, não sendo possível a dispersão da argila em água. Contudo, a secagem das amostras em estudo foi controlada e realizada à temperatura de aproximadamente $60^{\circ} \mathrm{C}$ de forma a evitar problemas de rehidratação.

A perda ao rubro $(\mathrm{PR})$ representa a perda de água intercalada, perda de água de hidroxilas dos argilominerais, matéria orgânica e carbonatos (SOUZA SANTOS, 1992). Para as amostras em estudo, observou-se que os teores de PR variaram de $6,58 \%$ para $8,66 \%$. Essa diferença deve-se ao fato de que algumas amostras 
apresentaram maior teor de compostos voláteis (hidroxilas, matéria orgânica, etc.) em sua composição.

Portanto, o conjunto de resultados mostrado na tabela 18, evidenciou uma composição química típica de bentonitas provenientes de Boa Vista - PB, de acordo com estudos realizados por Souza Santos (1992) e Amorim (2003).

\subsubsection{Análise Textural - Método BET}

$\mathrm{Na}$ tabela 19 encontram-se os resultados referentes à: área superficial, volume de poros e diâmetro do poro.

Tabela 19: Resultados de BET para as bentonitas da mina Lages.

\begin{tabular}{|cccccc}
\hline & Chocolate & Bofe & Chocobofe & Sortida & Verde Lodo \\
\hline $\begin{array}{c}\text { Área Superficial } \\
\left(\mathbf{m}^{2} \mathbf{~}^{-1}\right)\end{array}$ & 66,936 & 88,208 & 93,882 & 90,128 & 63,123 \\
$\begin{array}{c}\text { Volume do poro } \\
(\mathbf{p} / \mathbf{p} \mathbf{0}=\mathbf{0 . 3 7 1}) \\
\left(\mathbf{c m}^{\mathbf{3}} \mathbf{~}^{-1}\right)\end{array}$ & 0,038 & 0,051 & 0,053 & 0,051 & 0,036 \\
$\begin{array}{c}\text { Diâmetro do } \\
\text { poro }(\mathbf{n m})\end{array}$ & 2,319 & 2,323 & 2,3279 & 2,323 & 2,313 \\
\hline
\end{tabular}

Através da análise da tabela 19, observa-se que a argila que apresentou uma maior área específica foi a Chocobofe $\left(93,882 \mathrm{~m}^{2} \mathrm{~g}^{-1}\right)$, seguida da argila Sortida $\left(90,128 \mathrm{~m}^{2} \mathrm{~g}^{-1}\right)$ e da Bofe $\left(88,208 \mathrm{~m}^{2} \mathrm{~g}^{-1}\right)$, com relação às demais. Também percebeu-se que a argila Verde Lodo apresentou uma menor área específica $\left(63,123 \mathrm{~m}^{2} \mathrm{~g}^{-1}\right)$. Logo, pode-se afirmar que provavelmente as argilas Chocobofe e Sortida apresentarão uma melhor atividade catalítica, sendo considerados mais eficientes em aplicações diversas como catalisadores no processo (RODRIGUES et. al., 2006). A mesma tendência da área superficial foi observada para o volume de poros e o diâmetro de poros, ou seja, as argilas Chocobofe, Sortida e Bofe apresentam um maior volume de poros com maiores diâmetros.

Essa análise textural vem corroborar com os resultados encontrados na análise de DRX e FRX, sugerindo que provavelmente as argilas Chocobofe, Sortida e Bofe apresentarão um melhor comportamento catalítico devido à alta área específica. 
CAPÍTULO 5 APLICAÇÕES E USOS DA BENTONITA 


\section{CAPÍTULO 5- APLICACÕES E USOS DA BENTONITA}

Neste capítulo serão apresentados e discutidos os resultados das caracterizações para algumas aplicações e usos das bentonitas da mina Lages (Boa Vista-PB).

\subsection{APLICAÇÃO 1: BENTONITAS PARA TRATAMENTO DE EFLUENTES OLEOSOS}

Bilhões de metros cúbicos de água de descarte oleosa são gerados diariamente no mundo. As legislações ambientais cada vez mais rigorosas vêm obrigando as indústrias a tratarem esta água. O óleo presente na água descartada pode apresentar-se basicamente de três formas: óleo livre, emulsões instáveis e estáveis de óleo em água. O óleo livre e as emulsões instáveis podem ser mecanicamente e quimicamente tratados por métodos relativamente simples, mas as emulsões estáveis de óleo em água estáveis são as mais difíceis de serem separadas. Os tratamentos com os processos convencionais quando não são viáveis economicamente, não apresentam eficiência adequada de separação, além de produzir grandes quantidades de lama que necessitam também de tratamento (SILVA \& LIRA,2003).

Água misturada com óleo é produzida em grandes volumes em muitos processos industriais inclusive na produção de petróleo e refino de óleo. Esta mistura deve ser tratada para separar o óleo da água antes que possa retornar ao meio ambiente ou mesmo ser reutilizada no processo. Geralmente são instalados equipamentos de separação como coalescedores, sedimentadores por gravidade, flotadores com ar dissolvido dentre outros, visando reduzir as concentrações do óleo. Mas, em alguns casos estas tentativas não reduzem suficientemente o conteúdo de óleo.

As bentonitas formam diversos complexos com substâncias orgânicas. Desses complexos, os que tem encontrado maior uso são as argilas organofílicas. 
As argilas organofílicas são obtidas a partir de argilas esmectíticas e sais quaternários de amônio, possuindo ao menos uma cadeia com doze ou mais carbonos. Elas desfrutam de um grande número de aplicações nas diversas áreas tecnológicas, sendo amplamente utilizadas como componentes tixotrópicos em fluidos de perfuração de poços de petróleo à base de óleo, no refino de petróleo, na adsorção e retenção de resíduos industriais perigosos e contaminantes sólidos, na remoção de vários contaminantes orgânicos no tratamento de águas contaminadas, tratamento de efluentes industriais, em tanques de óleo ou gasolina e em revestimentos de aterros, tendo usos também, nas indústrias de fundição de metais, lubrificantes, tintas, adesivos e cosméticos.

Assim, considerando-se que áreas contaminadas por hidrocarbonetos do petróleo resultam em problemas ambientais sérios e muito comuns e visando a remediação desse problema, tem-se dado bastante destaque ao estudo de argilas organofílicas utilizadas como sorventes. O processo de separação de óleo/água utilizando argilas organofílicas poderá oferecer uma nova opção para enfrentar-se estes desafios.

Um dos grandes problemas das indústrias, em geral, é o tratamento dos seus efluentes antes do descarte no meio ambiente.

Uma boa parcela destes efluentes é constituída de emulsões de óleo em água. Estas emulsões são misturas de óleo e água caracterizadas principalmente por terem gotículas na faixa de 20 micrômetros ou menos. De acordo com o CONAMA 20/86 (Conselho Nacional do Meio Ambiente) (PINTO, 2000), o teor de óleos e graxas em efluentes não deve exceder $20 \mathrm{mg} / \mathrm{L}$. Em consequência disso, os diversos tipos de indústria devem implantar sistemas de tratamento para permitir a disposição dos seus efluentes no meio ambiente. A PETROBRAS, por exemplo, vem promovendo diversos estudos no sentido de melhorar seus sistemas de tratamento de efluentes em plataformas de extração de petróleo.

Os processos comuns para separação destas emulsões incluem métodos químicos, centrifugação, ultracentrifugação, tratamentos térmicos dentre outros. Cada um destes processos têm sérias limitações, seja de ordem energética, como no caso de tratamentos térmicos e mecânicos ou seja de ordem química. 
A crescente necessidade do desenvolvimento de processos de separações óleo/água mais eficazes, gerada principalmente pelas legislações ambientais cada vez mais rígidas, tem voltado à atenção para o uso de argilas organofílicas, geralmente usadas em conjunto com carvões ativados, no processo de tratamento de efluentes oleosos como uma nova tecnologia eficiente e economicamente viável.

Este trabalho faz parte de uma série que vem pesquisando a obtenção e caracterização de argilas organofílicas, visando seu uso na indústria petrolífera, no tratamento de substâncias contaminadas e na obtenção de nanocompósitos silicato/polímeros. Levando-se em consideração que o Estado da Paraíba possui as maiores reservas brasileiras de argilas esmectíticas e que praticamente não se produzem argilas organofílicas no Brasil e que não existem, do nosso conhecimento, estudos sobre a preparação e uso de argilas organofílicas na separação óleo/água. Portanto, o processo de separação óleo/água com argilas organofílicas poderá oferecer às indústrias petrolíferas, uma nova opção de tratamento de efluentes oleosos antes do seu descarte ao meio ambiente.

\subsubsection{OBJETIVO DESSE ESTUDO}

O objetivo para realização desse trabalho foi verificar o potencial do uso da bentonita Chocolate (sem tratamento e tratada com carbonato de sódio industrialmente) para o tratamento de efluentes oleosos.

\subsubsection{MATERIAIS UTILIZADOS}

Nesse estudo foram utilizados os seguintes materiais:

- Uma bentonita nacional sem tratamento proveniente do município de Boa Vista, Estado da Paraíba, denominada de Chocolate. A mesma, passou por um processo de moagem no LMPSol/PMT/USP (Laboratório de Matérias-Primas Particuladas e Sólidos Não-Metálicos do Departamento de Engenharia Metalúrgica e de Materiais da EPUSP), utilizando um moinho de facas da marca Thomas Wiley modelo 4, até atingir granulometria \#200. 
- Uma bentonita sódica comercial nacional, denominada por Fluid Gel. Ressalta-se que na composição da argila Fluid Gel há a presença em alto teor da bentonita chocolate e que foi tratada industrialmente com barrilha carbonato de sódio.

\subsubsection{METODOLOGIA UTILIZADA}

Para a aplicação foi necessário que as argilas em estudo fossem submetidas a um tratamento orgânico para posteriormente serem testadas em escala de laboratório realizado no sistema de separação óleo/água desenvolvido no laboratório do LMPSol/PMT/EPUSP. O detalhamento do processo de organofilização encontrase em trabalhos publicados por SILVA et.al. em 2002.

Ao término do tratamento foi possível observar o seguinte comportamento (figura 43): a bentonita deixou de ser hidrofílica e passou a ser organofílica.

ARGILA
HIDROFÍLICA

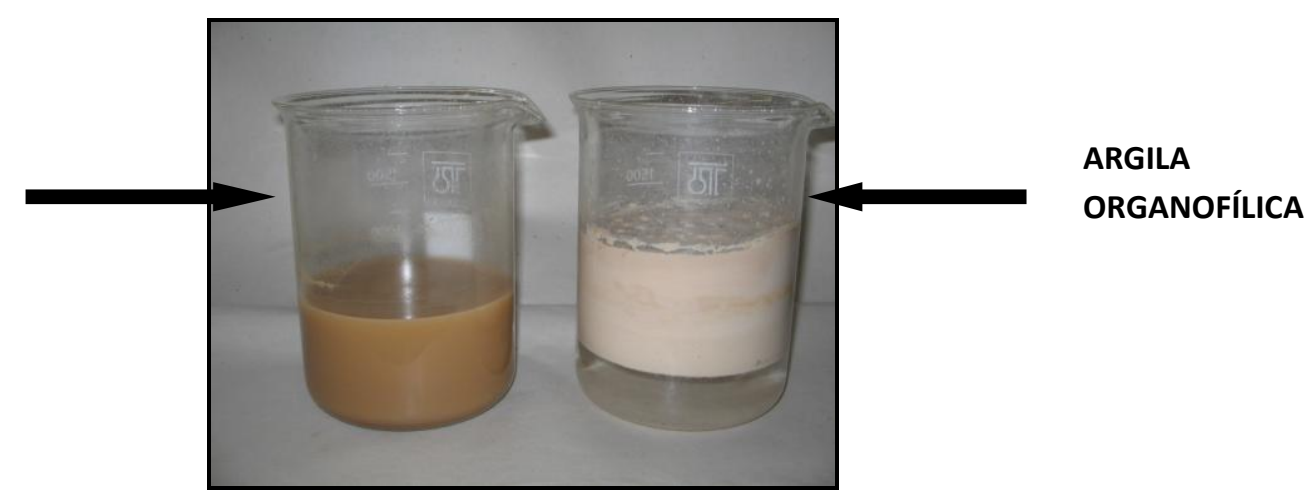

Figura 43: Comportamento das argilas.

Fonte: Adriana Silva (2005).

As caracterizações das argilas nacionais (sem tratamento, comercial e organofílica) foram efetuadas utilizando as seguintes técnicas de caracterização: Difração de raios X (DRX); Análises Térmicas: Análise Térmica Diferencial (DTA); Microscopia Eletrônica de Varredura (MEV); Espectroscopia por Energia Dispersiva (EDS); Capacidade de Adsorção em: etanol, xileno, querosene, óleo lubrificante, tolueno, gasolina e óleo diesel.

Para os testes, em escala de laboratório, de desempenho no sistema de separação óleo/água (figura 44), preparou-se emulsões com concentrações de 50 
ppm, 100 ppm, 500 ppm e 1000 ppm, agitadas durante 5 min, à temperatura ambiente, com uma velocidade de aproximadamente 1000 rpm.

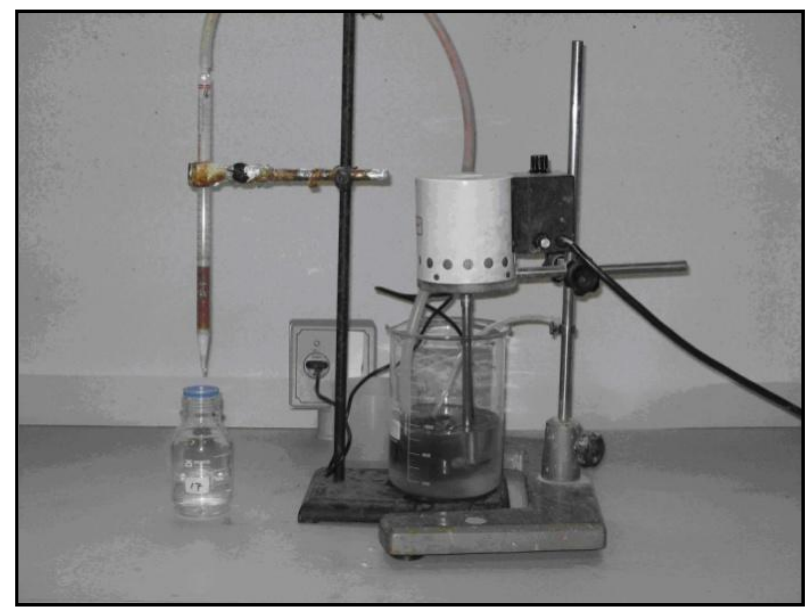

Figura 44: Visão geral do sistema de separação óleo/água.

Fonte: Adriana Silva, (2005).

Ao final do experimento, obteve-se 20 amostras que foram encaminhadas para análise no laboratório da empresa ACQUALAB, localizada em Jundiaí - SP (figura 45).

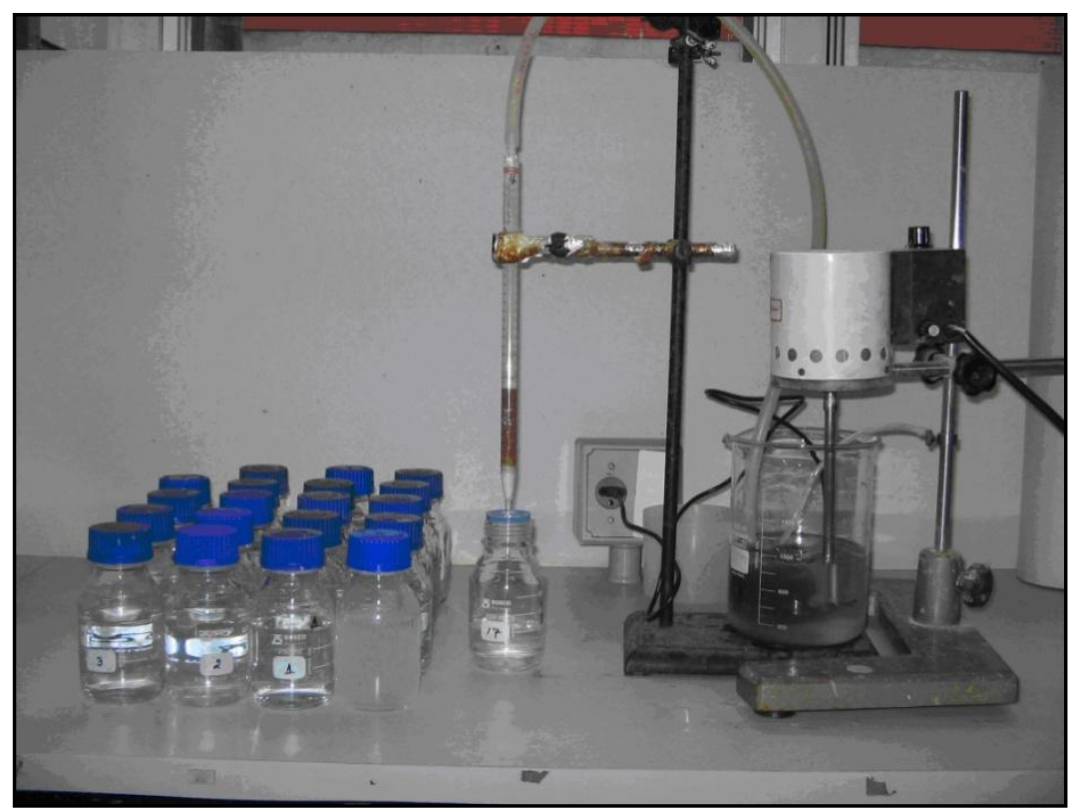

Figura 45: Ilustração detalhada das vinte amostras coletadas para análise. Fonte: Adriana Silva, (2005). 


\subsubsection{RESULTADOS OBTIDOS}

\subsubsection{Difração de raios $X$}

A caracterização das amostras por difração de raios $\mathrm{X}$, visa verificar a existência de minerais acessórios e de argilominerais.

Com a troca do cátion sódio pelo cátion do sal quaternário HDTMA - $\mathrm{Cl}$ (cloreto hexadeciltrimetilamônio-GENAMIN CTAC50), ocorre a expansão da camada da bentonita. Esta expansão é medida por difração de raios $X$.

As curvas de difração de raios - $X$ das argilas: Chocolate, Fluid Gel sem tratamento estão apresentados na figura 46 e 47.

As amostras da bentonita Chocolate com e sem tratamento apresentaram reflexão do grupo esmectítica que correspondem a distâncias basais $\left(\mathrm{d}_{001}\right)$ 12,6 $\AA$, 18,1 Á e 17,3 Á, respectivamente. Observa-se também, o seguinte pico principal que corresponde ao mineral não esmectítico: quartzo (Q) (WANG, C. C et. al.,2004; XI, Y, et.al.,2004; SHEM, Y. H, 2001; CHOY, J. H, 1997).

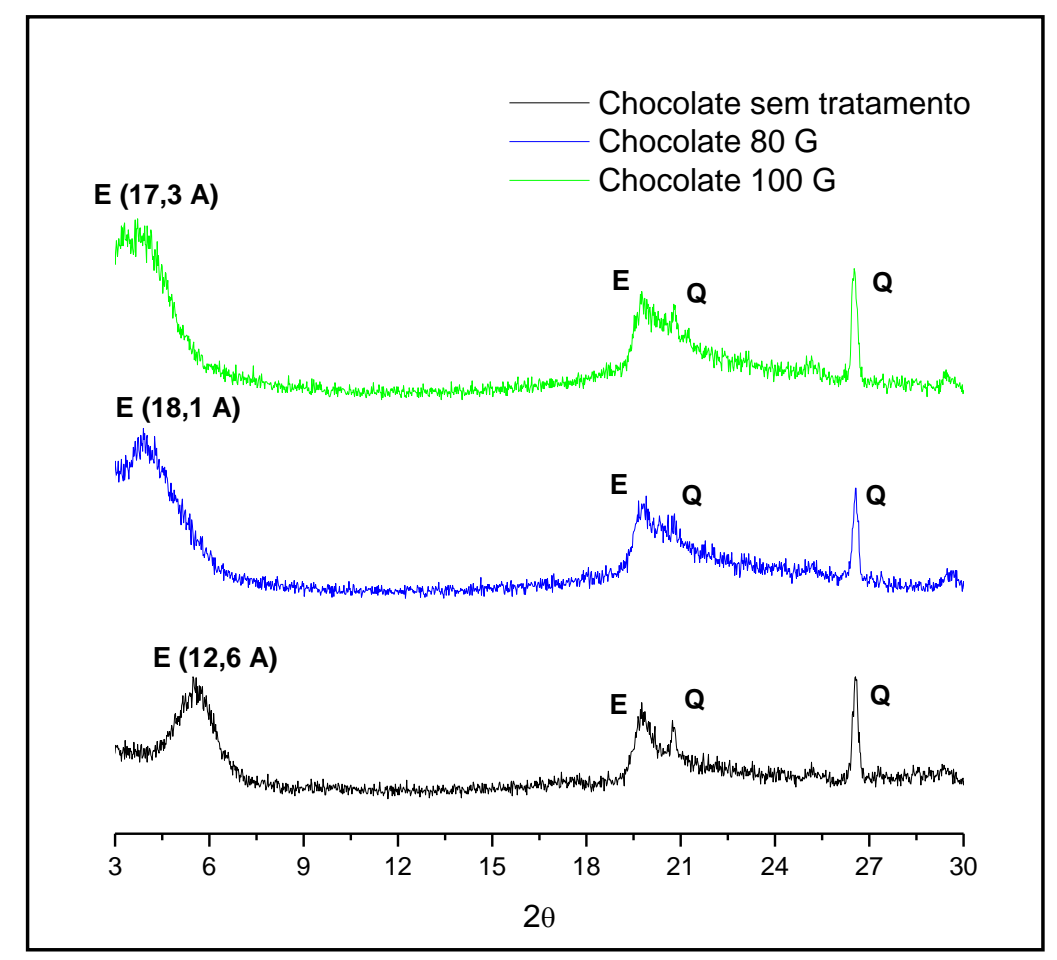

Figura 46: Curvas de raios $X$ da argila Chocolate sem tratamento e Chocolate modificada com o sal HDTMA-Cl (cloreto de hexadeciltrimetilamônio - GENAMINCTAC50) com diferentes concentrações. 
Percebe-se que quando as argilas Chocolate foram tratadas com 0 sal HDTMA-Cl (cloreto de hexadeciltrimetilamônio - GENAMIN CTAC50) nas concentrações de 80 meq e 100 meq, ocorreu modificações nos espaçamentos basais das argilas.

A argila Chocolate apresenta uma distância basal de 12,6 $\AA$, e é modificada com a incorporação do HDTMA-Cl, o valor da distância basal aumenta para 18,1 $\AA$, quando a concentração do HDTMA-Cl é de $80 \mathrm{meq} / 100 \mathrm{~g}$ (80G) e 17,3 $\AA$ quando a concentração do HDTMA-Cl é de $100 \mathrm{meq} / 100 \mathrm{~g}$ (100G). Estes resultados confirmam nossa hipótese de que o HDTMA-Cl foi intercalado nos espaços lamelares da argila Chocolate . A figura 46 mostra claramente o aumento da distância basal de 12,6 Á a 18,1 Á para a argila Chocolate sem tratamento e com o aumento da concentração do sal HDTMA-Cl (cloreto de hexadeciltrimetilamônio - GENAMIN-CTAC50).

Observa-se a partir da figura 47, os DRX da argila Fluid Gel sem tratamento e com tratamento.

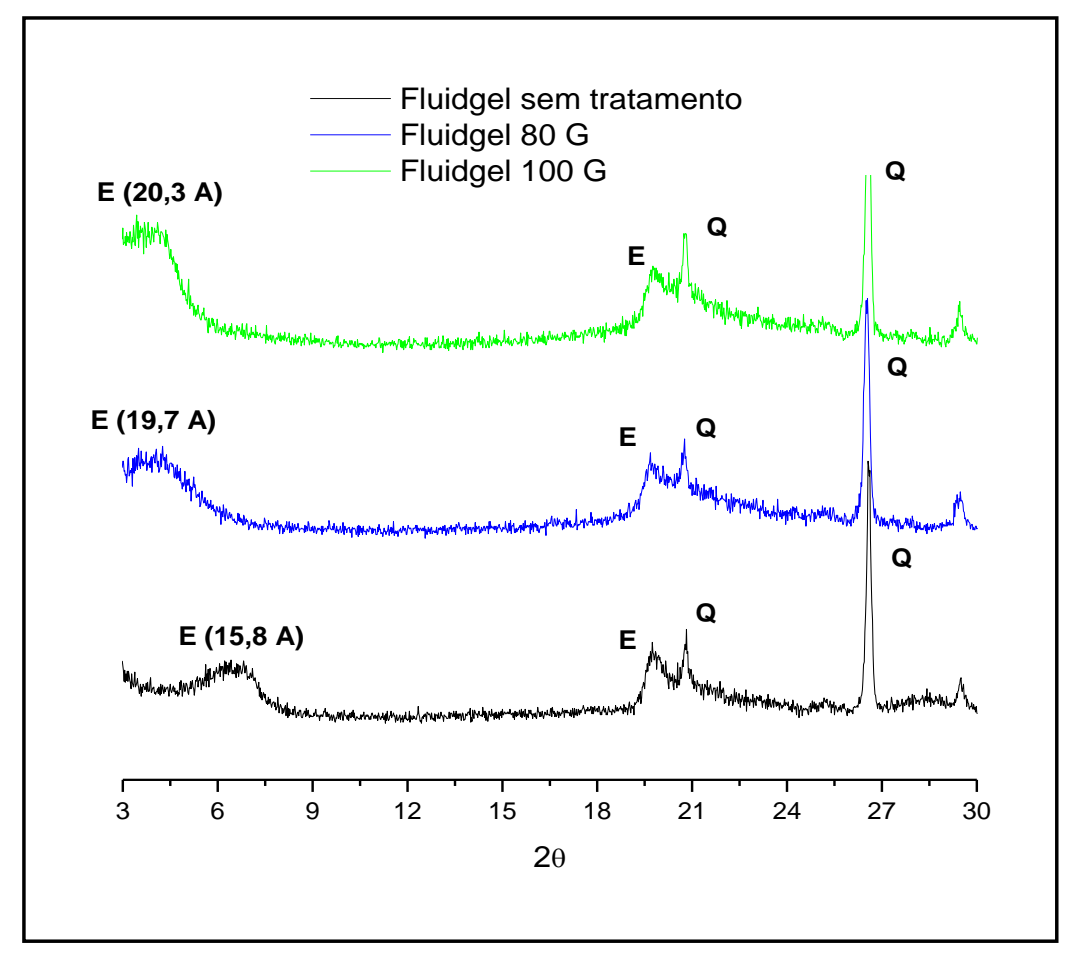

Figura 47: Curvas de raios $X$ da argila Fluid Gel sem tratamento e Fluid Gel modificada com o sal, HDTMA-Cl (GENAMIN-CTAC50) com diferentes concentrações. 
A argila Fluid Gel apresenta uma distância basal de 15,8 Á, e foi modificada com a incorporação do HDTMA-Cl, o valor da distância basal aumenta para 19,7Á, quando a concentração do HDTMA-Cl é de $80 \mathrm{meq} / 100 \mathrm{~g}$ (80G) e 20,3 Á quando a concentração do HDTMA-Cl foi de $100 \mathrm{meq} / 100 \mathrm{~g}$ (100G). Estes resultados podem ser atribuídos à introdução dos cátions quaternários na estrutura da argila Fluid Gel. O aumento da distância basal de 15,8 $\AA$ a 20,3 $\AA$ para a argila Fluid Gel sem tratamento e com o aumento da concentração do sal HDTMA-Cl (cloreto de hexadeciltrimetilamônio - GENAMIN-CTAC50).

Para as argilas: Fluid Gel 80G e Fluid Gel 100G, os valores são de 19,7Á e 20,3 Á, respectivamente. Isto significa que a organização do sal HDTMA-Cl (cloreto de hexadeciltrimetilamônio - GENAMIN-CTAC50), está provavelmente entre a bicamada e a estrutura com camada pseudotrimolecular (BOREZEK, J. L.; HARRIS, W. G.; KIZZA, P. N, 2002).

\subsubsection{Análise Térmica Diferencial (DTA)}

As figuras de 48 a 49 mostram as curvas DTA (análise térmica diferencial) e TG (termogravimétrica) das amostras Chocolate e Fluid Gel sem e com tratamento com o HDTMA-CI (cloreto de hexadeciltrimetilamônio - GENAMIN-CTAC50).

As análises térmicas das curvas das argilas Chocolate sem tratamento e modificada com o sal HDTMA-Cl (cloreto de hexadeciltrimetilamônio - GENAMINCTAC50), estão apresentadas na figura 48.

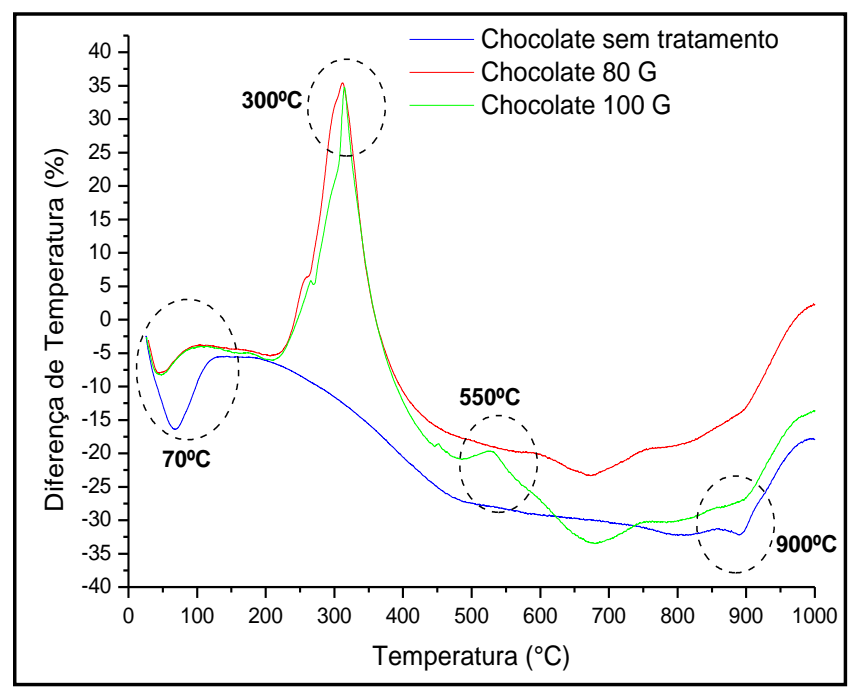

Figura 48: Curvas de análises térmicas: DTA da amostra Chocolate modificada com o sal HDTMA-CI (GENAMIM CTAC50) com diferentes concentrações. 
A análise térmica diferencial para a argila Chocolate sem tratamento na figura 46 exibe um pico endotérmico que ocorre entre $30^{\circ} \mathrm{C}$ e $140^{\circ} \mathrm{C}$, acompanhado pela perda de água livre e um pico endotérmico entre $490^{\circ} \mathrm{C}$ e $550^{\circ} \mathrm{C}$ causado pela perda de hidroxila estrutural. O pico exotérmico a $850^{\circ} \mathrm{C}$ é estrutural. Este comportamento exotérmico pode ser atribuído à destruição da estrutura da montmorilonita.

A curva de análise térmica diferencial obtida para a argila Chocolate tratada com o sal HDTMA-Cl (cloreto de hexadeciltrimetilamônio - GENAMIN-CTAC50), com concentração de $80 \mathrm{meq} / 100 \mathrm{~g}$ revela um pico endotérmico que ocorre entre $20^{\circ} \mathrm{C}$ e $100^{\circ} \mathrm{C}$, acompanhado pela perda de água livre, um pico exotérmico que ocorre entre $200^{\circ} \mathrm{C}$ e $400^{\circ} \mathrm{C}$, atribuído à decomposição do sal quaternário HDTMA-Cl (cloreto de hexadeciltrimetilamônio - GENAMIN-CTAC50). Após a etapa de liberação da água residual e combustão da parte orgânica proveniente do sal quaternário de amônio, ocorrem dois picos superpostos: o primeiro deve-se à desidroxilação da argila organofílica, e o segundo, à combustão do resíduo carbonoso da queima anterior, caracterizada pelo largo pico de DTA exotérmico (SORA, I. N, et.al. 2005).

As análises térmicas das curvas das argilas Fluid Gel sem tratamento e modificada com o sal HDTMA-Cl (cloreto de hexadeciltrimetilamônio - GENAMINCTAC50), estão apresentadas na figura 49.

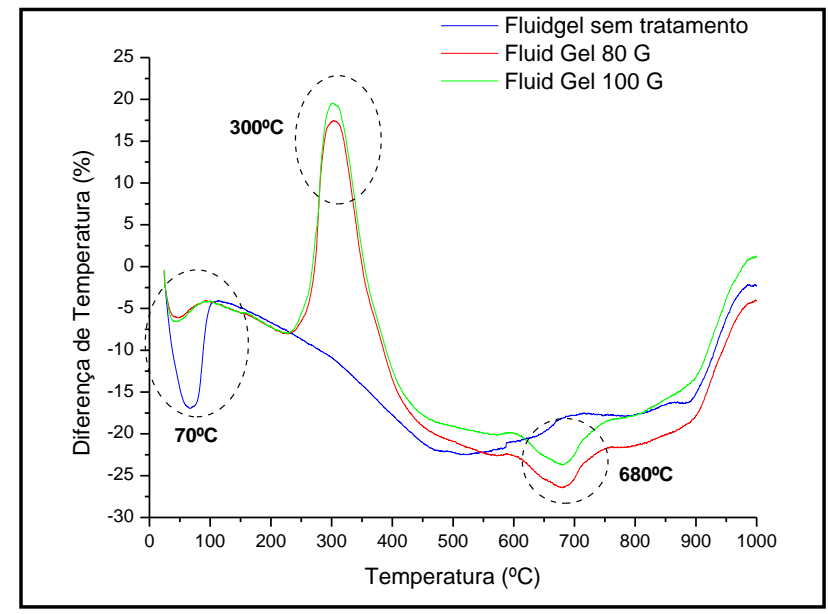

Figura 49: Curvas de análises térmicas: DTA da amostra Fluid Gel modificada com o sal HDTMA-CI (GENAMIM CTAC50) com diferentes concentrações. 
A análise térmica diferencial para a argila Fluid Gel sem tratamento encontrase apresentada na figura 49 e mostra claramente que há um pico endotérmico que ocorre entre $40^{\circ} \mathrm{C}$ e $150^{\circ} \mathrm{C}$, acompanhado pela perda de água livre e um pico endotérmico entre $500^{\circ} \mathrm{C}$ e $550^{\circ} \mathrm{C}$ causado pela perda de hidroxila estrutural. O pico exotérmico a $800^{\circ} \mathrm{C}$ é estrutural. Este comportamento exotérmico é devido provavelmente à destruição da estrutura da montmorilonita.

A curva de análise térmica diferencial obtida para a argila Fluid Gel tratada com o sal HDTMA-Cl (cloreto de hexadeciltrimetilamônio - GENAMIN-CTAC50), com concentração de $80 \mathrm{meq} / 100 \mathrm{~g}$ revela um pico endotérmico que ocorre entre $30^{\circ} \mathrm{C}$ e $100^{\circ} \mathrm{C}$, acompanhado pela perda de água livre, um pico exotérmico que ocorre entre $230^{\circ} \mathrm{C}$ e $410^{\circ} \mathrm{C}$, atribuído à decomposição do sal quaternário HDTMA-CI (cloreto de hexadeciltrimetilamônio - GENAMIN-CTAC50). Após a etapa de liberação da água residual e combustão da parte orgânica devida à presença do sal quaternário de amônio, ocorrem dois picos superpostos: o primeiro refere-se à desidroxilação da argila organofílica, e o segundo, à combustão do resíduo carbonoso da queima anterior, caracterizada pelo largo pico de DTA exotérmico (SORA, I. N, et.al. 2005).

\subsubsection{Microscopia Eletrônica de Varredura (MEV)}

Foram realizadas análises das imagens de microscopia eletrônica de varredura nas amostras de bentonitas com e sem tratamento com o sal quaternário de amônio HDTMA-Cl (cloreto de hexadeciltrimetilamônio): Chocolate e Fluid Gel . A morfologia das argilas pode ser vista através das figuras de 50 a 52.

Segundo Neaman et. al. (2003), uma argila lamelar seca pode ser descrita por três unidades estruturais e pelo arranjo dessas unidades no espaço:

- A primeira unidade é a camada (partícula cristalina elementar), no caso das esmectitas de espessura de 10 Á e de diâmetro entre 1 e 2 нm. 
- A segunda unidade é o tactóide que é constituído pelo empilhamento das camadas elementares.

- A terceira unidade é o aglomerado, constituído por vários tactóides. Os aglomerados se organizam em "cachos" (clusters).

Para cada tipo de unidade estrutural existe um tipo correspondente de porosidade. De acordo com Teixeira (2001), existem os microporos correspondentes ao empilhamento das camadas elementares, com diâmetro de até 20 Á. Há também, os mesoporos (20 a $400 \AA \hat{\text { ) }}$, correspondentes aos poros intertactóides, causados pelo arranjo das partículas dos tactóides. E finalmente os macroporos (>500 $\AA$ ), poros interaglomerados que podem existir nos "cachos", correspondentes aos espaços vazios deixados pelos aglomerados.

As micrografias eletrônicas de varredura para a amostra Chocolate sem tratamento e Chocolate modificada com o sal HDTMA-Cl (cloreto de hexadeciltrimetilamônio ), estão apresentadas nas figuras 50 a 52.

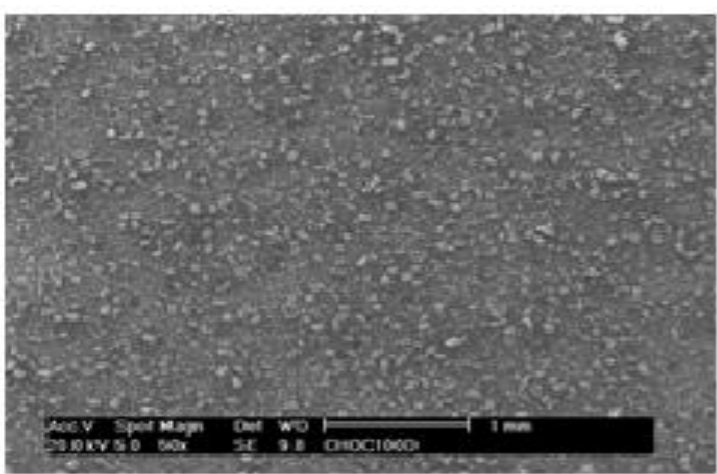

(a)

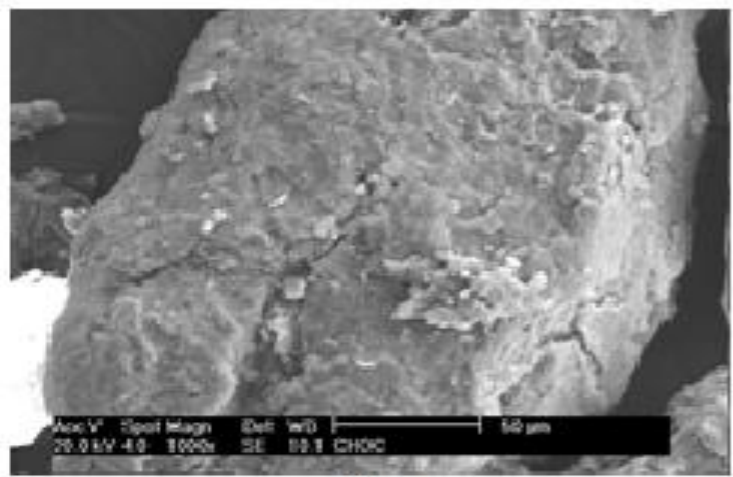

(c)

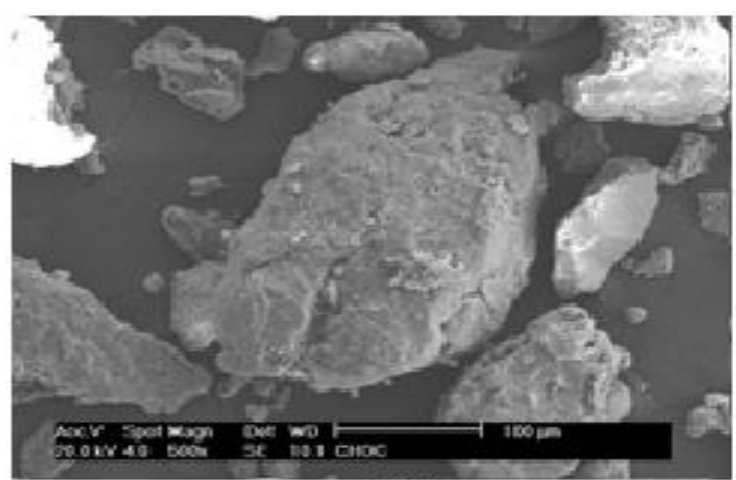

(b)

Figura 50: Microscopia eletrônica de varredura para a amostra Chocolate sem tratamento, com aumentos de: (a) x 50, (b) x 500 e (c) $\times 1000$. 


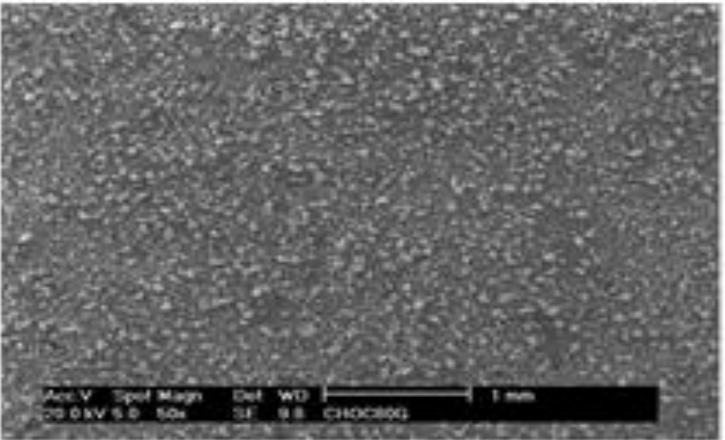

(a)

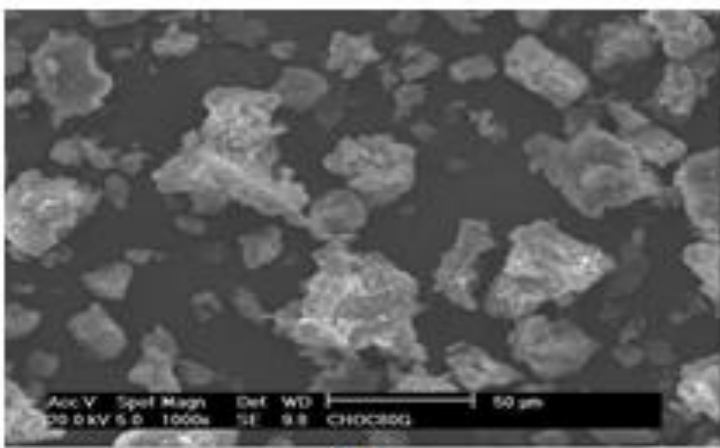

(c)

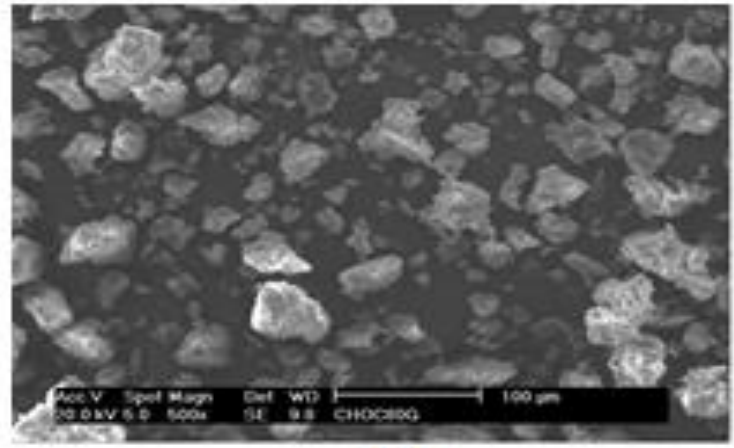

(b)

Figura 51: Microscopia eletrônica de varredura para a amostra Chocolate modificada com o sal HDTMA-Cl (80G), com aumentos de: (a) x 50, (b) x 500 e (c) x 1000.

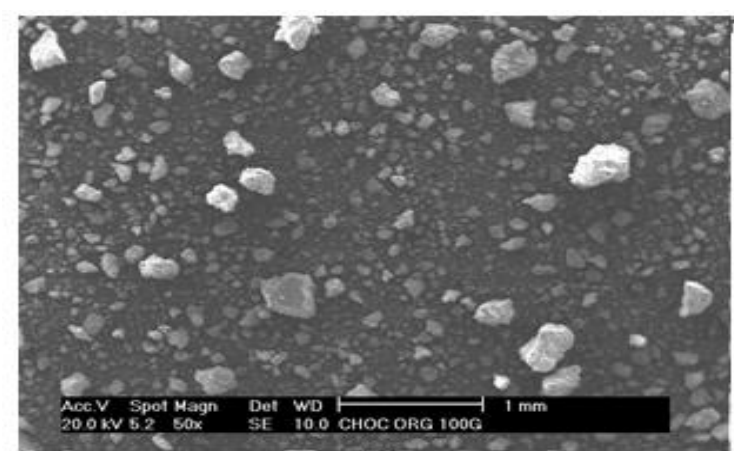

(a)

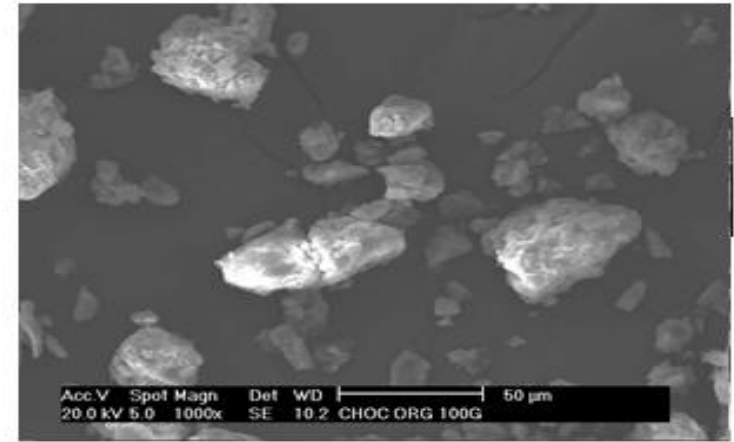

(c)

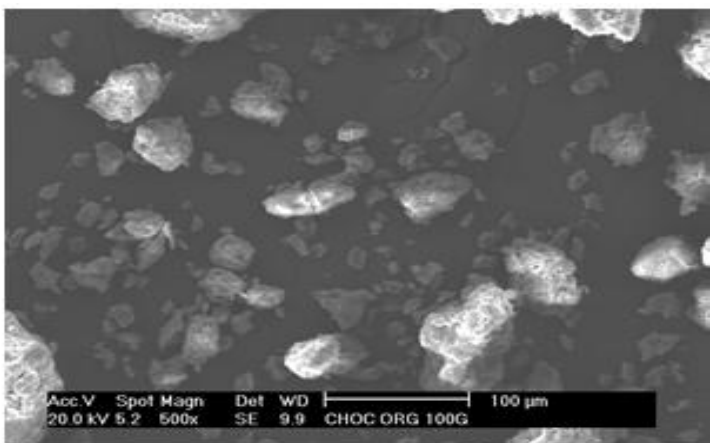

(b)

Figura 52: Microscopia eletrônica de varredura para a amostra Chocolate modificada com o sal HDTMA-Cl (100G), com aumentos de: (a) x 50, (b) x 500 e (c) x 1000. 
De forma geral, a partir de observações diretas das microscopias eletrônicas de varredura (figuras 50 a 52), é possível verificar que todas as amostras de bentonita Chocolate com e sem tratamento, por serem bentonitas, apresentam morfologias similares. Portanto, observa-se que não há uma distribuição muito homogênea de partículas, pois apresentam grãos de diversos tamanhos, ocasionando, portanto, uma distribuição de partículas irregular. Observa-se ainda, que essas amostras são constituídas por aglomerados de perfil irregular (BOREZEK, J. L.; HARRIS, W. G.; KIZZA, P. N , 2002).

Verifica-se a morfologia lamelar das camadas que formam as partículas elementares, assim como os tactóides (JOSÉ, C. V 2003), formados pelo empilhamento dessas partículas lamelares. Observam-se também, os tactóides ligados entre si, formando aglomerados de diversas dimensões.

As microscopias eletrônicas de varredura para a amostra Fluid Gel sem tratamento e Fluid Gel modificada com o sal HDTMA-Cl (cloreto de hexadeciltrimetilamônio ), estão apresentadas nas figuras 53 a 55.

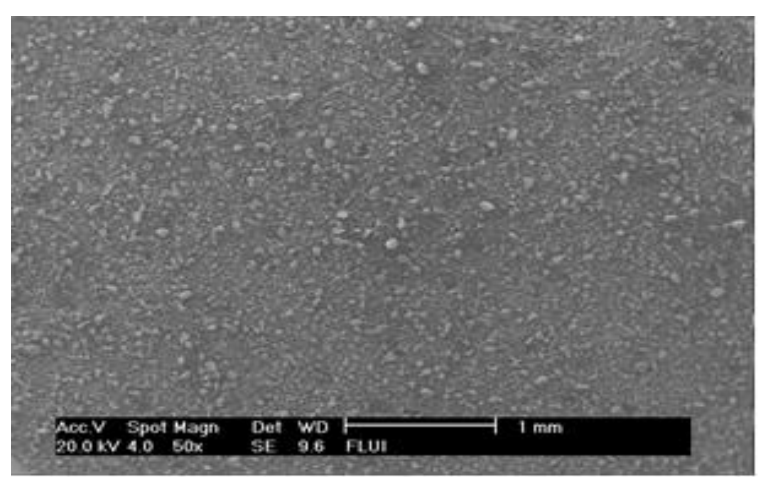

(a)

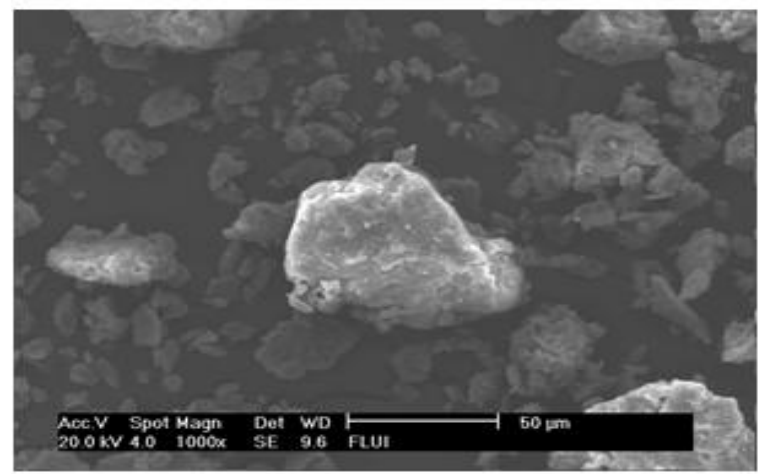

(c)

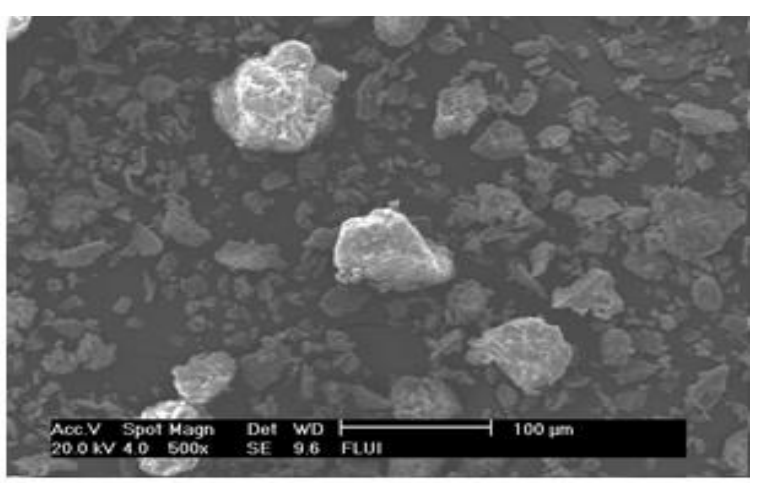

(b)

Figura 53: Microscopia eletrônica de varredura para a amostra Fluid Gel sem tratamento, com aumentos de: (a) x 50, (b) x 500 e (c) $\times 1000$. 


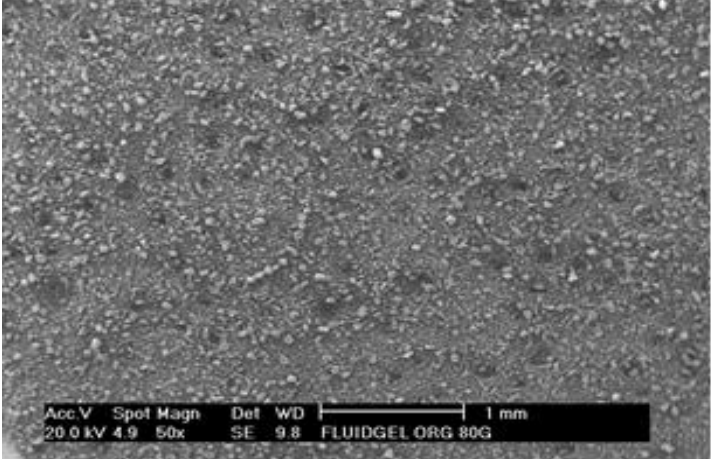

(a)

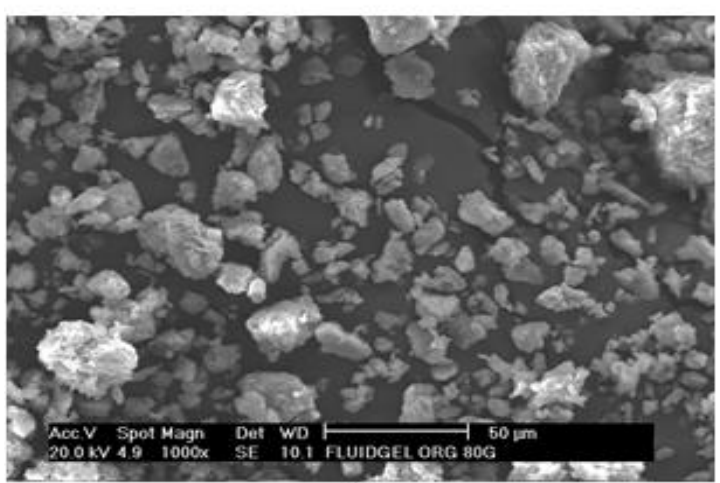

(c)

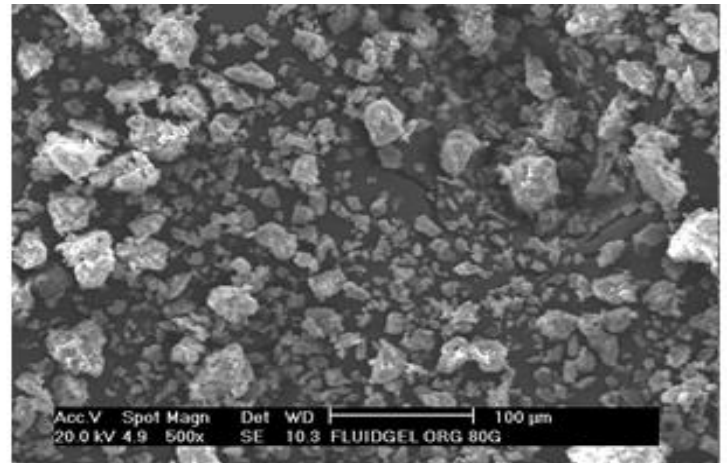

(b)

Figura 54: Microscopia eletrônica de varredura para a amostra Fluid Gel modificada com o sal HDTMA-Cl (80G), com aumentos de: (a) x 50, (b) x 500 e (c) x 1000.

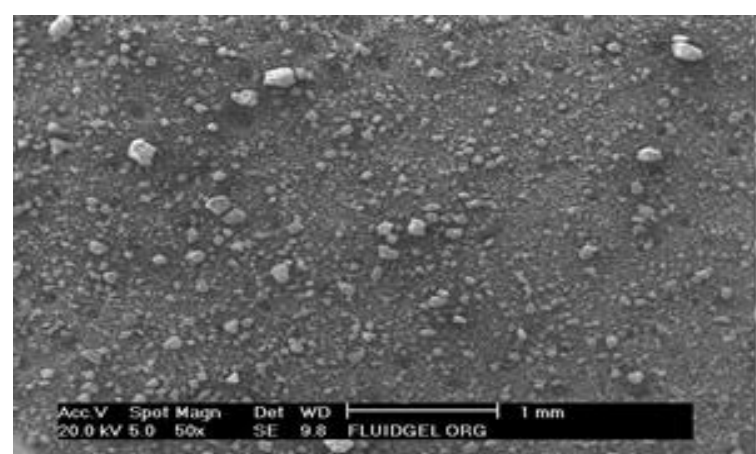

(a)

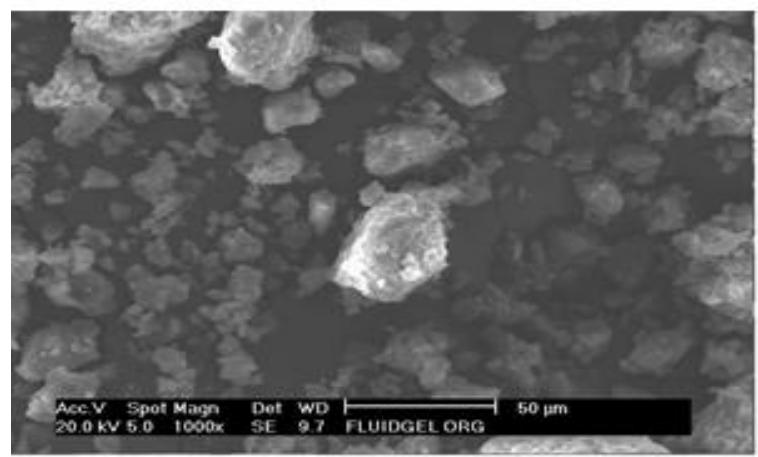

(c)

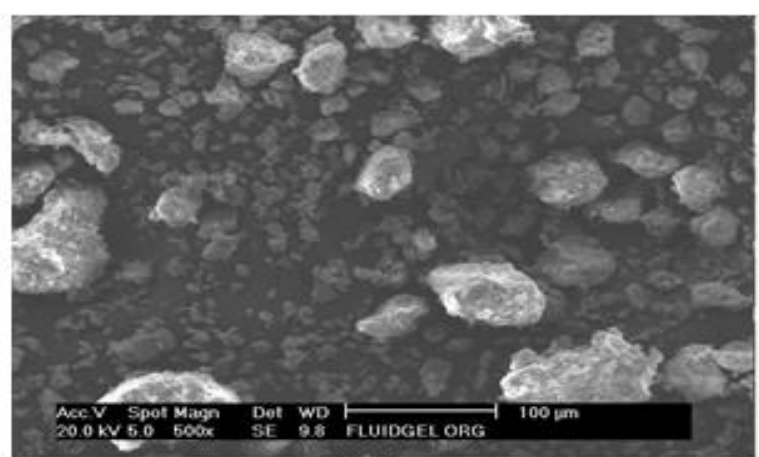

(b)

Figura 55: Microscopia eletrônica de varredura para a amostra Fluid Gel modificada com o sal HDTMA-Cl (100G), com aumentos de: (a) x 50, (b) x 500 e (c) x 1000. 
A partir das micrografias da amostra Fluid Gel mostrada na figura 53 (a), pode-se observar as partículas com diâmetros de aproximadamente 43,90 $\mu \mathrm{m}$. $\mathrm{Na}$ figura 53 (b), observa-se um aglomerado com superfície mais ou menos lisa, onde não se distingue claramente a morfologia lamelar dos tactóides que o compõe. Também é possível observar nesta figura tactóides soltos. Na imagem ampliada deste aglomerado (1000X), mostrada na figura 53 (c), é possível distinguir os contornos lamelares de partículas elementares dos tactóides que estão ligados entre si (SHEM, Y. H., 2001).

Através da análise dos dados da tabela 20 , podemos verificar que todas as amostras de bentonitas sem tratamento com o sal quaternário de amônio, apresentaram um diâmetro médio de partículas superiores as das respectivas amostras tratadas com o sal quaternário de amônio. Este comportamento indica que o tratamento com o sal HDTMA-Cl (cloreto de hexadeciltrimetilamônio), provoca uma diminuição no tamanho das partículas.

Tabela 20: Variação das dimensões dos aglomerados de partículas das argilas hidrofílicas e organofílicas estudadas.

\begin{tabular}{cccc} 
Amostra & $\begin{array}{c}\text { Sem } \\
\text { tratamento }\end{array}$ & \multicolumn{2}{c|}{$\begin{array}{c}\text { Com tratamento } \\
\text { (Sal Genamim) }\end{array}$} \\
\hline Chocolate & 150,65 & $\begin{array}{c}\mathbf{0 , 8 m e q} / \mathbf{g ~ d e} \\
\text { argila (80G) }\end{array}$ & $\begin{array}{c}\mathbf{1 , 0 m e q} / \mathbf{g ~ d e} \\
\text { argila (100G) }\end{array}$ \\
Fluidgel & 43,90 & 15,81 & 18,50 \\
\hline
\end{tabular}

Para concentrações do sal HDTMA-Cl (cloreto de hexadeciltrimetilamônio) $80 \mathrm{meq} / 100 \mathrm{~g}$ e $100 \mathrm{meq} / 100 \mathrm{~g}$, verificou-se que não houve alteração significativa no tamanho das partículas. 


\subsubsection{Espectroscopia por Energia Dispersiva (EDS)}

No mesmo microscópio onde foram realizadas as microscopias eletrônicas de varredura para as amostras Chocolate e Fluid Gel (com e sem tratamento), foram realizadas análises para a identificação dos elementos químicos presentes através do acessório de EDS anexado ao equipamento.

$\mathrm{Na}$ figura 56 são apresentados os resultados obtidos para a amostra Chocolate: (a) sem tratamento, (b) com tratamento na concentração de $80 \mathrm{meq} / 100 \mathrm{~g}$ de argila e (c) com tratamento na concentração de $100 \mathrm{meq} / 100 \mathrm{~g}$ de argila.
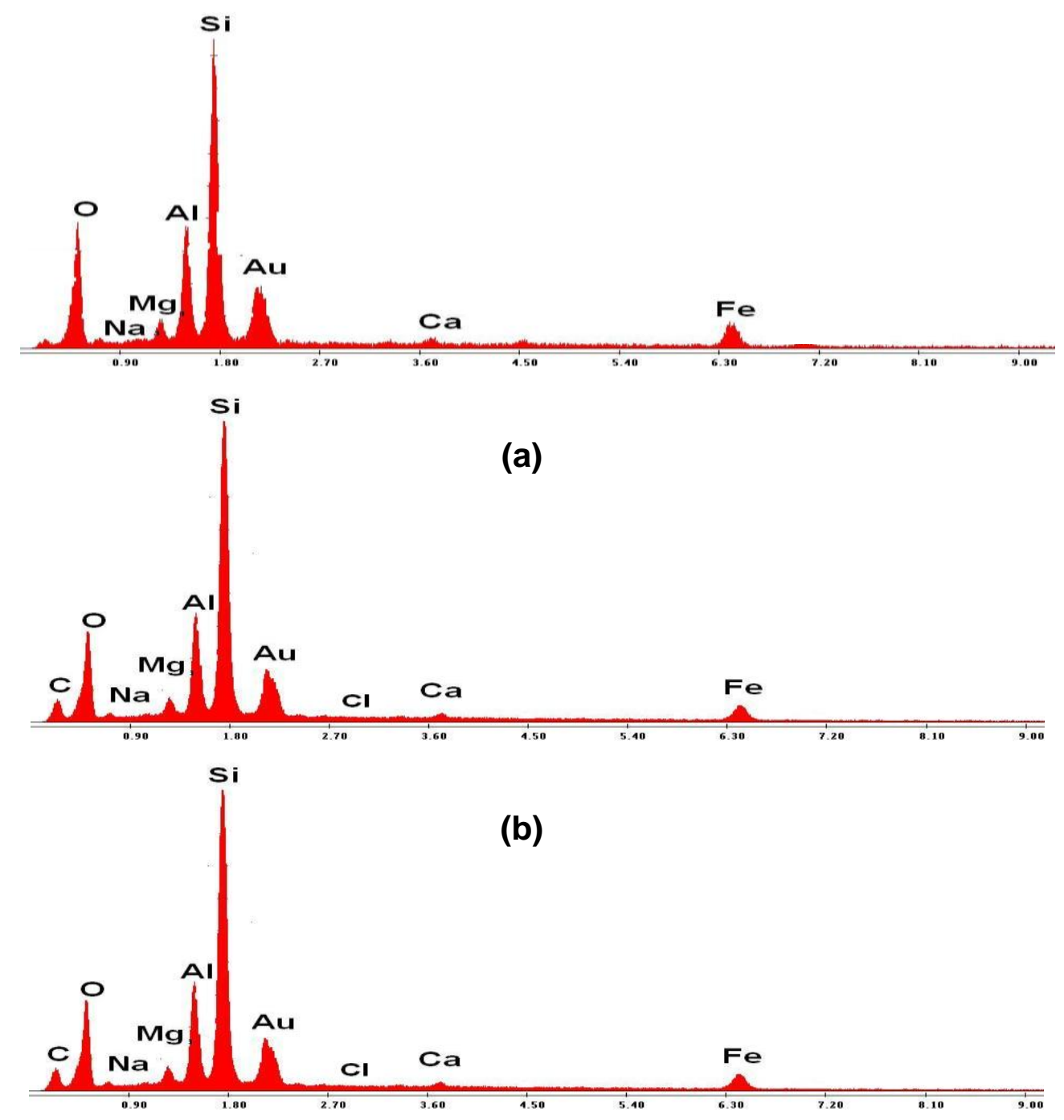

(c)

Figura 56: Espectroscopia por energia dispersiva das bentonitas Chocolate. (a) sem tratamento, (b) com tratamento com o sal HDTMA-Cl na concentração de 80G de argila e (c) com tratamento com o sal HDTMA-Cl na concentração de 100G de argila. 
Através da análise de EDS verificou-se que a amostra Chocolate sem tratamento apresenta em sua composição, basicamente, Si e Al, característico de bentonitas da Paraíba. Apresentou-se traços de $\mathrm{Na}, \mathrm{Mg}$ e Ca e também Fe em sua composição.

Ao observar as argilas Chocolate com tratamento com o sal HDTMA-Cl (cloreto de hexadeciltrimetilamônio), independente da concentração $(80 \mathrm{meq} / 100 \mathrm{~g} \mathrm{e}$ $100 \mathrm{meq} / 100 \mathrm{~g}$ ), é possível identificar qualitativamente os mesmos compostos presentes na argila sem tratamento, além do $\mathrm{Cl}, \mathrm{O}$ e $\mathrm{C}$, provenientes da composição do sal HDTMA-Cl (cloreto de hexadeciltrimetilamônio).

$\mathrm{Na}$ figura 57 são apresentados os resultados obtidos para a amostra Fluid Gel: (a) sem tratamento, (b) com tratamento na concentração de $80 \mathrm{meq} / 100 \mathrm{~g}$ de argila e (c) com tratamento na concentração de $100 \mathrm{meq} / 100 \mathrm{~g}$ de argila.

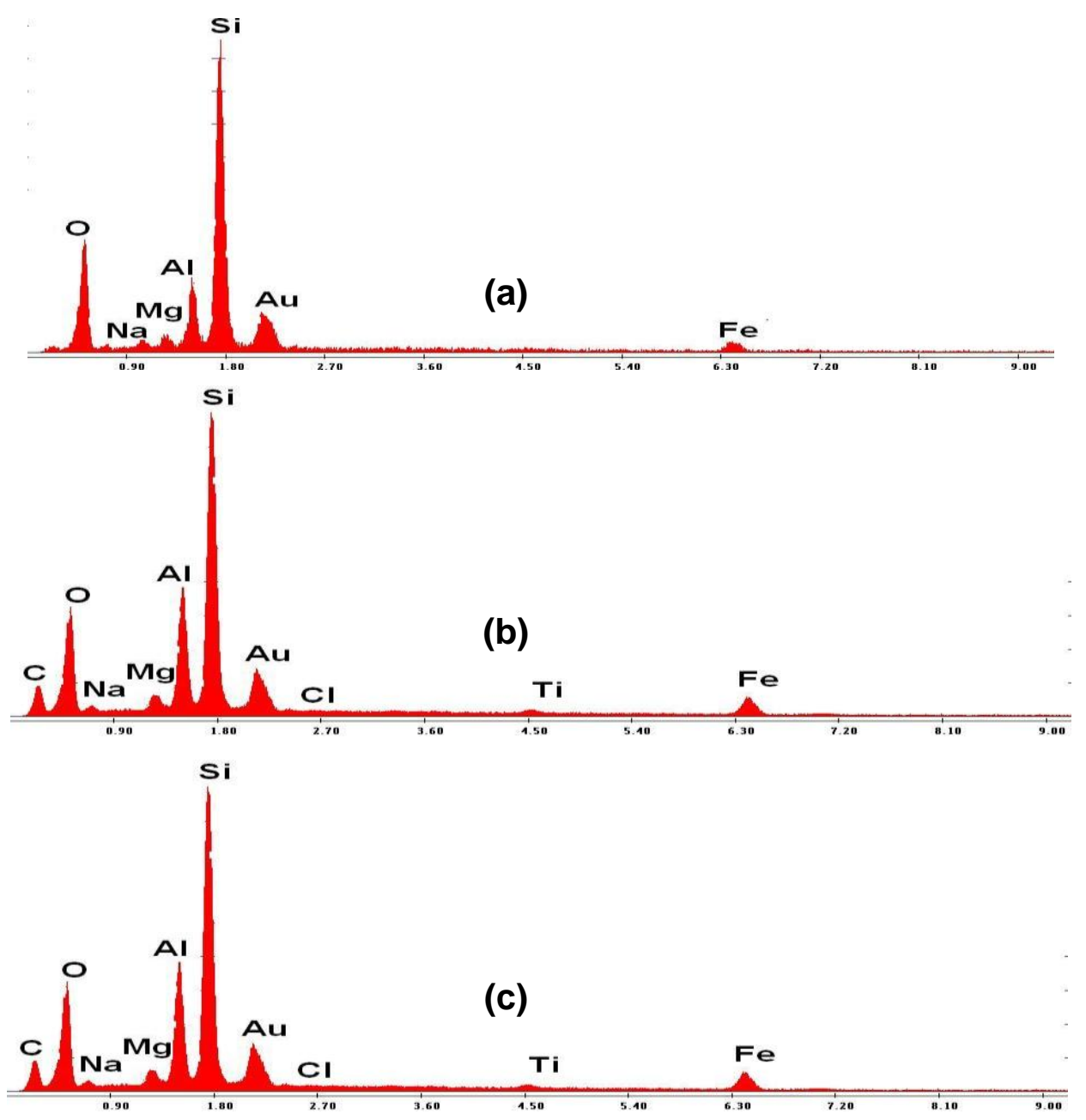

Figura 57: Espectroscopia por energia dispersiva das bentonitas Fluid Gel. (a) sem tratamento, (b) com tratamento com o sal HDTMA-Cl na concentração de 80G de argila e (c) com tratamento com o sal HDTMA-Cl na concentração de 100G de argila. 
Comportamento análogo ao da argila Chocolate sem tratamento e com tratamento com o sal HDTMA-Cl (cloreto de hexadeciltrimetilamônio), pode ser verificado para as argilas Fluid Gel sem e com o tratamento com o sal HDTMA-Cl (cloreto de hexadeciltrimetilamônio) com diferentes concentrações $(80 \mathrm{meq} / 100 \mathrm{~g} \mathrm{e}$ $100 \mathrm{meq} / 100 \mathrm{~g})$.

\subsubsection{Capacidade de adsorção em solventes orgânicos}

Com o objetivo de fazer a medida da capacidade de adsorção dos materiais organofílicos, bem como, das cinco respectivas amostras naturais, utilizou-se a metodologia baseada na norma ASTM F 726 -99 (NOVICKIS, R. W, 2005 ).

Baseado nos trabalhos de Pereira (2003), foi escolhido o óleo lubrificante como solvente orgânico. Os resultados referentes a essa análise são apresentados através dos gráficos em anexo.

Analisando a figura 58 foi possível verificar que as amostras organofílicas apresentaram um melhor potencial de adsorção nos respectivos solventes.

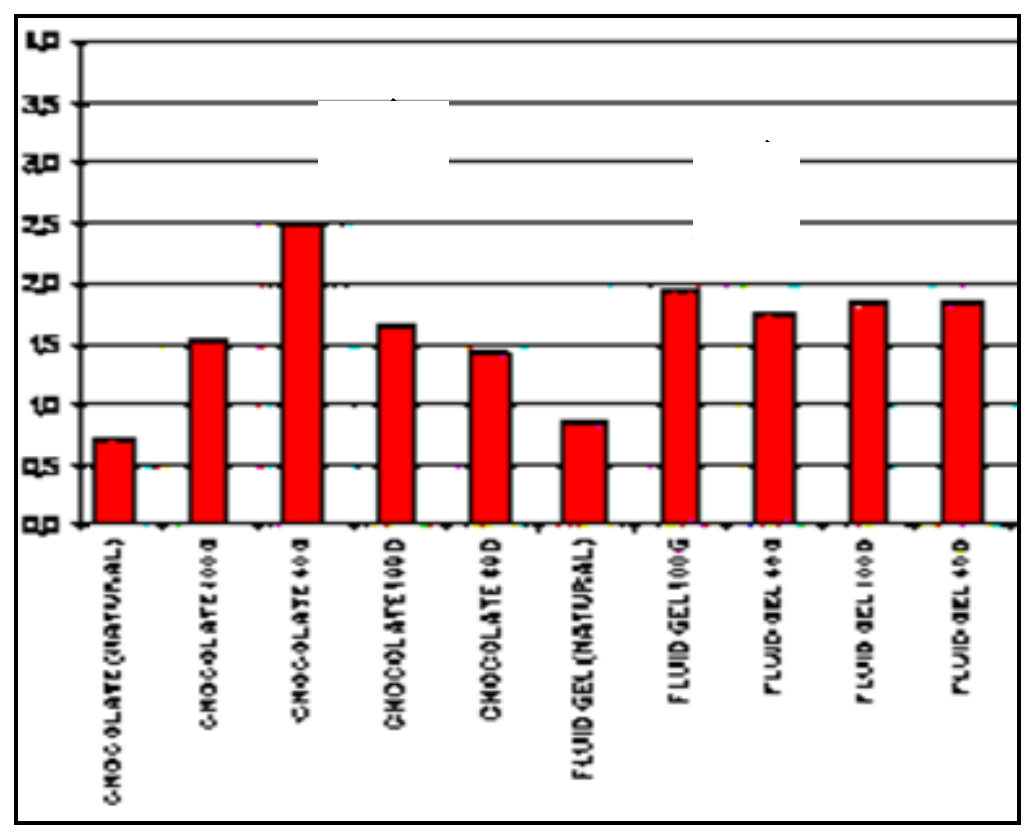

Figura 58: Capacidade de Adsorção em óleo lubrificante.

Fazendo uma análise desses dados foi possível destacar as seguintes amostras:

- Para o óleo lubrificante: Chocolate $80 \mathrm{G}(2,50 \pm 0,5 \% \mathrm{~g} / \mathrm{g})$. 
Tendo em vista que o solvente a ser utilizado no teste da separação óleo/água seria o óleo lubrificante, decidiu-se escolher para realização desse ensaio as duas amostras que apresentaram maior eficiência no teste de capacidade de adsorção em solventes orgânicos. Foi então escolhida a melhor amostra dentre as sem tratamento, a melhor amostra dentre as comercias.

A figura 59 mostra uma comparação do potencial de adsorção das 2 amostras escolhidas.

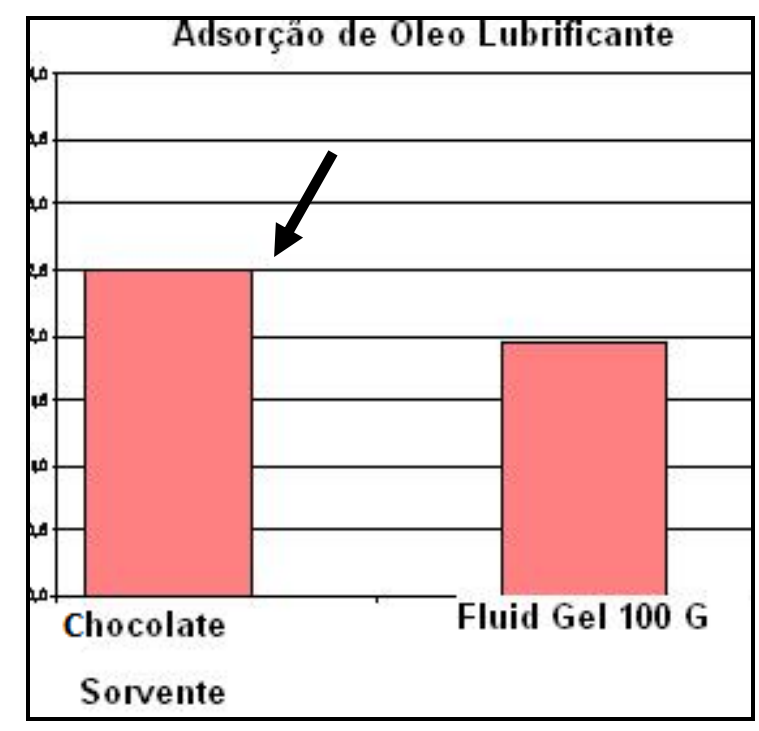

Figura 59: Capacidade de adsorção em óleo lubrificante $(\mathrm{g} / \mathrm{g})$ das amostras com tratamento com o sal HDTMA-Cl (cloreto de hexadeciltrimetilamônio) na concentração de $80 \mathrm{meq} / 100 \mathrm{~g}$, Chocolate sem tratamento e Fluid Gel com tratamento com o sal HDTMA-Cl (cloreto de hexadeciltrimetilamônio) na concentração de $100 \mathrm{meq} / 100 \mathrm{~g}$.

Fazendo uma análise geral da figura 59, observa-se que as amostras que apresentaram um melhor potencial de adsorção foram: Chocolate 80G, Fluid Gel 100G. Percebe-se ainda que todas as duas amostras selecionadas foram tratadas com o sal quaternário de amônio GENAMIM CTAC-50.

Portanto, analisando a figura 59 é possível observar que dentre as 2 amostras escolhidas (Chocolate $80 \mathrm{G}$ e Fluid Gel 100G), a amostra que apresentou um melhor desempenho de adsorção em óleo lubrificante foi a amostra Chocolate 80G. 


\subsubsection{Análise do teor de óleo/água}

Visando realizar uma análise do teor de óleo/água foram realizados testes, através de um sistema de separação óleo/água em escala de laboratório, com as amostras, Chocolate $80 \mathrm{G}$, Fluid Gel $100 \mathrm{G}$ e Carvão ativado. O carvão ativado foi utilizado como referência, uma vez que é utilizado na separação óleo/água (ALTHER, 2002).

Preparou-se emulsões com concentrações de 50 ppm, 100 ppm, 500 ppm e 1000 ppm, de óleo em água.

Para avaliação da eficiência de separação foram coletadas em frascos Pirex, $200 \mathrm{~mL}$ da concentração de óleo no permeado e levadas para análise. Esses resultados encontram-se descritos através da tabela 21.

Através da análise da tabela 21 é possível verificar que as amostras (Chocolate, Fluid Gel e Carvão ativado) apresentaram um comportamento similar, pois as mesmas evidenciaram uma concentração de óleo no permeado inferior a $0,01 \mathrm{ppm} \pm 1 \%$. Observa-se ainda que mesmo variando as concentrações (50 ppm, $100 \mathrm{ppm}, 500 \mathrm{ppm}$ e $1000 \mathrm{ppm}$ ) as amostras permaneceram na mesma faixa de concentração (inferior a $0,01 \mathrm{ppm}$ ) apresentando, portanto um desempenho satisfatório de adsorção de óleo e sugerindo que o processo é eficiente para separação óleo/água dentro das condições utilizadas. Esses valores encontram-se de acordo com o exigido pelo CONAMA (PINTO, W. D, 2000).

Tabela 21: Resultados da separação óleo/água.

\begin{tabular}{ccc} 
Amostras & $\begin{array}{c}\text { Concentração de } \\
\text { óleo inicial da } \\
\text { emulsão (ppm) }\end{array}$ & $\begin{array}{c}\text { Concentração de óleo } \\
\text { no permeado (ppm) }\end{array}$ \\
\hline CHOCOLATE & 50 & Inferior a 0,01 \\
80G & 100 & Inferior a 0,01 \\
& 500 & Inferior a 0,01 \\
& 1000 & Inferior a 0,01 \\
& 50 & Inferior a 0,01 \\
\hline
\end{tabular}




\begin{tabular}{ccc}
\hline FLUID GEL & 100 & Inferior a 0,01 \\
\hline $100 \mathrm{G}$ & 500 & Inferior a 0,01 \\
& 1000 & Inferior a 0,01 \\
\hline CARVÃO & 50 & Inferior a 0,01 \\
ATIVADO & 100 & Inferior a 0,01 \\
& 500 & Inferior a 0,01 \\
& 1000 & Inferior a 0,01 \\
\hline
\end{tabular}

As Figuras 60 e 61 abaixo mostram as coletas do permeado realizadas antes e após o experimento de separação óleo/água.

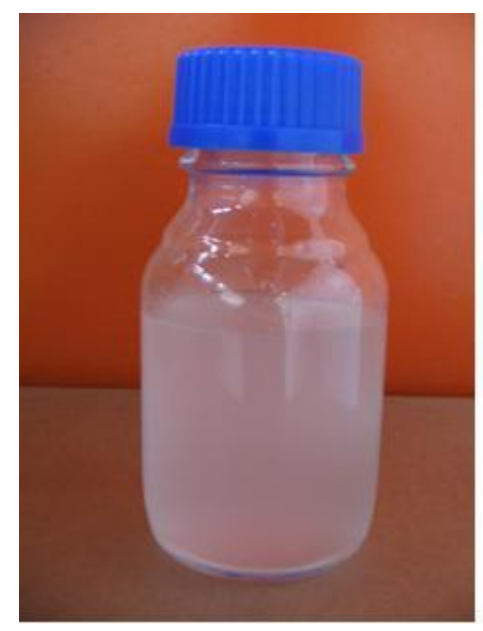

(a)

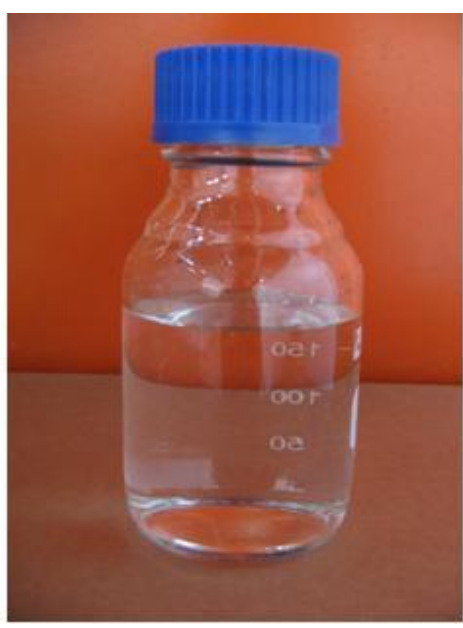

(b)

Figura 60: llustração das amostras coletadas através do sistema de separação óleo/água (a) amostra coletada antes de passar pela argila organofílica; (b) amostra coletada após ter passado pela argila organofílica.

Fonte: Adriana Silva, (2005). 


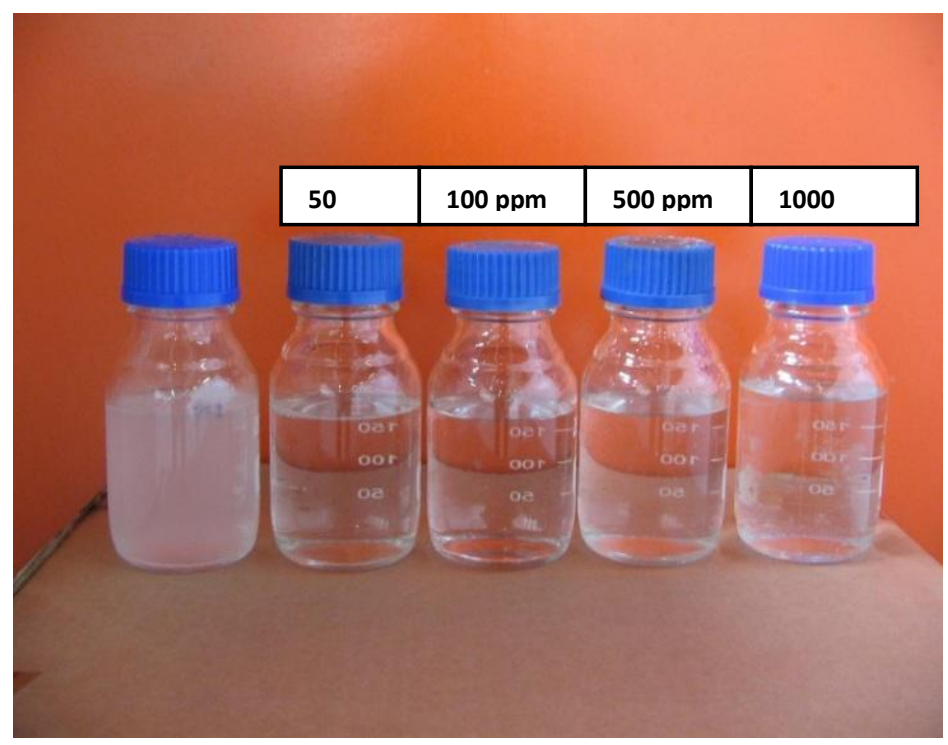

Figura 61: llustração do conjunto de amostras coletadas através do sistema de separação óleo/água.

Fonte: Adriana Silva, (2005).

Através das figuras 60 e 61, foi possível verificar (visualmente) que realmente ocorreu uma redução da concentração do teor de óleo na água. A variação das concentrações de óleo em água de 50 ppm, 100 ppm, 500 ppm e 1000 ppm não afetou o desempenho de adsorção de óleo das argilas organofílicas, confirmando a eficiência do sistema e do material utilizado para separação óleo/água.

\subsubsection{CONCLUSÃO DESSE ESTUDO}

\section{Com relação à caracterização das argilas:}

\section{Argila Chocolate}

- As mudanças na distância basal sugerem a formação de bicamadas de sais quaternários (HDTMA-Cl) nos espaços interlamelares. A argila Chocolate sem tratamento apresenta uma distância basal de 12,6 $\AA$, e é modificada com a incorporação do HDTMA-Cl, o valor da distância 
basal aumenta para 18,1 Á, quando a concentração do HDTMA-Cl é de $80 \mathrm{meq} / 100 \mathrm{~g}$ (80G) e 17,3 Á quando a concentração do HDTMA-Cl é de $100 \mathrm{meq} / 100 \mathrm{~g}$ (100G).

- A presença do sal quaternário de amônio (HDTMA-Cl) nos espaços interlamelares foi confirmada por Análise Térmica Diferencial, independente da concentração do sal.

- O processo de intercalação não causou modificações substanciais na morfologia das partículas da montmorilonita, independente da concentração do sal.

\section{Argila Fluid Gel}

- As modificações na distância basal sugerem a formação de bicamadas de sais quaternários de amônio (HDTMA-Cl) nos espaços lamelares e estrutura com camada pseudotrimolecular. A argila Fluid Gel sem tratamento apresenta uma distância basal de $15,8 \AA \hat{A}$, e é modificada com a incorporação do HDTMA-Cl, o valor da distancia basal aumenta

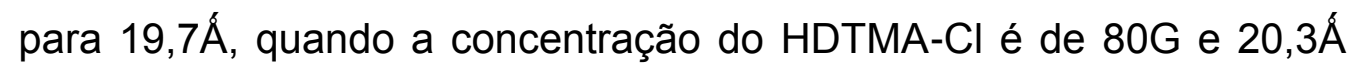
quando a concentração do HDTMA-Cl é de 100G.

- A presença do sal quaternário de amônio (HDTMA-Cl) nos espaços interlamelares foi confirmada por Análise Térmica Diferencial independente da concentração do sal.

- O processo de organofilização não causou modificações substanciais na morfologia das partículas da argila, independente da concentração do sal.

\section{Com relação à capacidade de adsorção:}

- Através da análise da capacidade de adsorção, verificou-se que as amostras organofílicas: Chocolate 80G e Fluid Gel 100G apresentaram uma maior capacidade de adsorção quando comparadas as demais amostras. 


\section{Com relação à análise do teor de óleo/água:}

- $\quad$ Através da análise do teor de óleo/água verificou-se que as amostras apresentaram um comportamento similar, pois as mesmas evidenciaram uma concentração de óleo no permeado inferior a 0,01 ppm \pm $1 \%$. Observa-se ainda que mesmo variando as concentrações (50 ppm, 100ppm, 500ppm e 1000ppm) as amostras permaneceram na mesma faixa de concentração (inferior a 0,01 ppm) apresentando, portanto um desempenho satisfatório de adsorção de óleo e comprovando a eficiência do processo de separação óleo/água, pois esses valores encontram-se de acordo com o exigido pelo CONAMA . Logo, as argilas organofílicas Chocolate (sal HDTMA-Cl com concentração $80 \mathrm{meq} / 100 \mathrm{~g}$ ), Fluid Gel (sal HDTMA-Cl com concentração $100 \mathrm{meq} / 100 \mathrm{~g}$ ) são materiais promissores para separação óleo/água. 


\subsection{APLICAÇÃO 2: BENTONITAS COMO CATALISADORES PARA PRODUÇÃO DO BIODIESEL}

Nos últimos anos, a situação energética mundial vem sendo agravada por sérios problemas ambientais, visto que a maior parte de toda a energia consumida no mundo provém de fontes fósseis (do petróleo e seus derivados, do carvão e do gás natural), além disso, se continuarem com o consumo atual, essas fontes estarão limitadas com previsão de esgotamento no futuro. O maior vilão é o combustível diesel, que é queimado pelas usinas termoelétricas, pelos caminhões e navios do mundo inteiro (FAGUNDES, 2006).

Diversos estudos sobre o emprego de fontes renováveis têm-se intensificado, devido às crises energéticas e o superaquecimento global do planeta Terra. Através desses estudos estão sendo desenvolvidos combustíveis menos poluentes a base de biomassa na produção de biodiesel, tendo como proposta básica à transformação de matéria-prima renovável em combustíveis alternativos aos clássicos combustíveis derivados de petróleo, com baixo custo de produção e, sobretudo, de menor impacto ambiental (FERRARI, OLIVEIRA e SACBIO, 2005).

Nesse contexto, os óleos vegetais aparecem como alternativa viável frente ao diesel utilizado em motores de ignição por compressão. Os óleos mais empregados como matérias-primas na produção do diesel vegetal (biodiesel), são: óleos vegetais (soja, babaçu, amendoim, algodão, oiticica, pinhão manso, girassol, dendê, mamona, canola, milho, pequi, etc), gorduras animais (sebo bovino e óleos de peixes), óleos e gorduras residuais (esgotos municipais, águas residuais de processos de certas indústrias) (KOUTROUBRAS, PAPAKOSTA e DOITSINIS, 1999). Logo, a utilização de biodiesel como combustível tem se apresentado como uma alternativa promissora no mundo inteiro (REZENDE, et. al., 2005).

No Brasil, os estudos sobre combustíveis alternativos iniciaram na década de 70, com a experiência do Proálcool, o qual foi implementado devido ao choque do petróleo e a idéia de utilizar no Brasil o biodiesel, surgiu na Universidade Estadual do Ceará, na década de 70 (PLÁ, 2002). A utilização do biodiesel como combustível na matriz energética brasileira representa uma grande contribuição tecnológica para 
o país, porque além de reduzir a dependência em relação a utilização do petróleo é uma forma de fortalecer o agronegócio. O biocombustível cria um novo mercado para óleos vegetais, servindo como suporte às políticas governamentais na área social e ambiental.

O biodiesel foi definido pela "National Biodiesel Board" em 1998 como sendo um derivado mono-alquil éster de ácidos graxos de cadeia longa, obtidos principalmente a partir da transesterificação de óleos vegetais ou gordura animal, cuja utilização está associada à substituição de combustíveis fósseis em motores de ignição por compreensão (motores de ciclo diesel) (RAMOS, 1999). A reação de transesterificação é conduzida na presença de um álcool de cadeia pequena e de um catalisador adequado. Pode ser catalisada por um ácido ou base, usando processo catalítico homogêneo ou heterogêneo. A reação empregada industrialmente utiliza comumente hidróxido de sódio ou potássio como catalisador. Estes catalisadores possuem custo relativamente baixo e fornecem alto nível de conversão em pouco tempo. Por outro lado, a sua utilização na transesterificação de óleos vegetais produz emulsão, em virtude da neutralização dos ácidos graxos livres e da saponificação do triacilglicerídeo. A formação de emulsão consome parte do catalisador, diminui o rendimento em biodiesel, o que dificulta etapas de separação e purificação do biocombustível conforme relatado por Rezende (2005). A remoção destes catalisadores é tecnicamente difícil e traz um custo extra ao produto final. Adicionalmente, a inabilidade para reciclagem e geração de grande quantidade de resíduo torna o uso de catalisadores tradicionais cada vez menos favoráveis.

Com o objetivo de minimizar problemas associados ao processo homogêneo convencional, estudos têm sido realizados empregando sistemas catalíticos heterogêneos para produção de biodiesel. Estes catalisadores simplificam e economizam as etapas de tratamento do produto. Podem ser facilmente separados do sistema por filtração e podem ser reutilizados. Dentre os catalisadores reportados na literatura, estão incluídas: enzimas, zeólitas, resinas de troca iônica, argilas, entre outros (RAMOS, 1999).

As argilas ativadas têm atraído atenção como catalisadores para uma variedade de reações ácidas. O comportamento físico-químico dos minerais argilosos tem sido estudado devido à sua relação com adsorvente e/ou propriedades 
catalíticas. Este comportamento é governado pela extensão e natureza da superfície externa, que pode ser modificada por tratamentos químicos e térmicos, os quais aumentam a atividade catalítica e adsorvente de minerais argilosos, mas tratamentos muito fortes diminuem esta atividade. Assim, é importante compreender como se modificam as propriedades texturais, bem como as propriedades de superfície sob diferentes condições de ativação das argilas. As propriedades estruturais destes materiais podem ser modificadas por métodos de ativação para produzir catalisadores com alta acidez, alta área específica, alta porosidade e termicamente estáveis. A ativação ácida de minerais argilosos é um dos métodos propostos mais efetivos para produzir materiais ativos para adsorção e catálise.

Diante do exposto verifica-se a necessidade que se desenvolvam estudos sobre a utilização de argilas como catalisador na produção do biodiesel, tornandose, portanto fundamental conhecer a estabilidade (térmica, química e biológica) e propriedades do biodiesel produzido a partir desses catalisadores.

\subsubsection{OBJETIVO DESSE ESTUDO}

O objetivo para realização desse trabalho foi verificar o potencial do uso das bentonitas Bofe e Verde Lodo como catalisadores para produção do biodiesel.

\subsubsection{MATERIAIS UTILIZADOS}

Foram fornecidos um total de 27 amostras de argilas diferentes para 0 desenvolvimento dessa pesquisa, pela empresa de minerais não metálicos BENTONISA - Bentonita do Nordeste S.A. Esses materiais encontravam-se nas formas "in natura", sódicas, ácidas e tratadas termicamente.

Segundo a empresa fornecedora, as argilas "in natura" foram extraídas de diversas localidades da Paraíba, dentre elas pode-se destacar as cidades de Boa Vista-PB (minas Lages, Lagedo, Juá), Junco e Cubati.

As argilas na forma sódica fornecidas para essa pesquisa são materiais sódicos ativados industrialmente através do carbonato de sódio, via processo convencional (cuja descrição detalhada não foi autorizada pela empresa). 
As argilas ácidas fornecidas para essa pesquisa, são de materiais de natureza ácida, ativados industrialmente e em laboratório através de processo convencional (cuja descrição detalhada não foi autorizada pela empresa).

Tendo em vista o potencial demonstrado pelos caulins quando ativados termicamente, a empresa forneceu para essa pesquisa, caulins tratados termicamente a $600^{\circ} \mathrm{C}$ e $1000^{\circ} \mathrm{C}$.

Para produção do biodiesel foram utilizados os seguintes reagentes:

- Óleo de soja comercial e refinado;

- Álcool Etílico Absoluto 98\% Anidro (Merck);

- Álcool Metílico Absoluto 98\% Anidro (Merck).

\subsubsection{METODOLOGIA UTILIZADA}

A metodologia desse trabalho está dividida em cinco etapas:

- ETAPA 1 - Seleção das Matérias-Primas;

- ETAPA 2 - Composições Estudadas ;

- $\quad$ ETAPA 3 - Sistemas para Preparação do Biodiesel;

- ETAPA 4 - Caracterização das Amostras de Argila Selecionadas;

- ETAPA 5 - Caracterização do Óleo de Soja e do Biodiesel.

\subsubsection{ETAPA 1- Seleção das Matérias Primas}

$\mathrm{Na}$ primeira etapa foram selecionadas as matérias-primas: amostras de argilas e definido o óleo vegetal a ser transesterificado. 


\section{- Seleção das Argilas}

As amostras de argilas utilizadas como catalisadores para produção do biodiesel foram selecionadas em duas fases. Na fase 1, foram selecionadas 15 amostras baseadas nas propriedades de teor de umidade (TU) e pH para serem posteriormente testadas nos sistemas $\mathrm{S} 1$ e $\mathrm{S} 2$. $\mathrm{Na}$ fase 2, foram selecionadas 2 amostras, baseadas na propriedade da análise de viscosidade dinâmica, para serem testadas no sistema 3.

\section{Fase 1: Seleção Inicial das Argilas}

De posse das 27 amostras de argilas, foi realizada uma seleção baseada no teor de umidade e $\mathrm{pH}$ das mesmas. As amostras selecionadas foram testadas nos sistemas S1 e S2. Na figura 62 é mostrado o fluxograma dessa seleção.

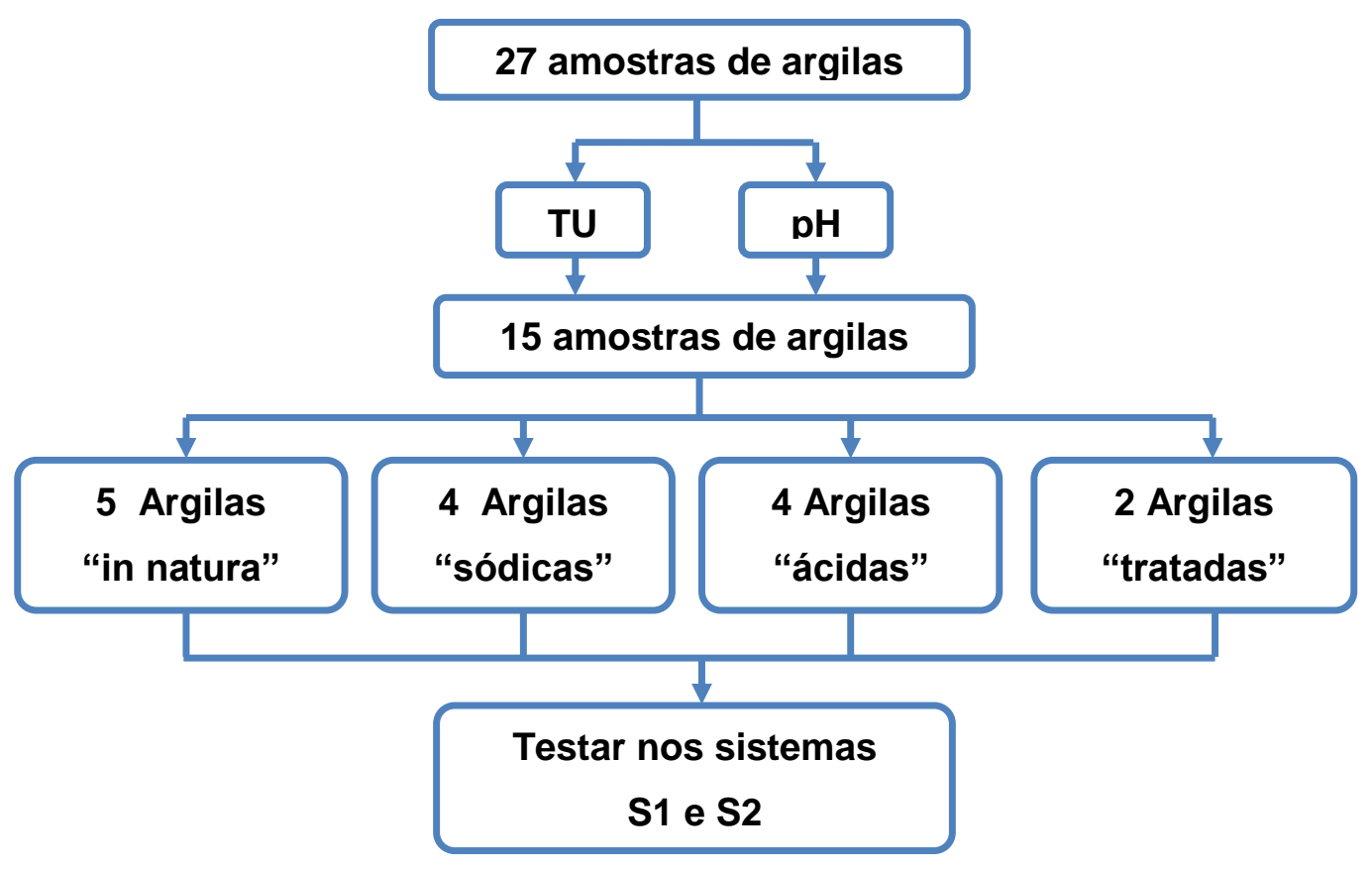

Figura 62: Fluxograma demonstrando a seleção inicial das argilas.

Logo, para essa pesquisa foram selecionadas, dentre as 27 amostras de argilas inicial, um total de 15 argilas diferentes a serem testadas como catalisadores na preparação do biodiesel. As amostras selecionadas estariam distribuídas da seguinte forma:

- 5 amostras de argilas "in natura"; 
- 4 amostras de argilas sódicas;

- 4 amostras de argilas ácidas;

- 2 amostras de argilas tratadas termicamente.

\section{Fase 2: Seleção Final das Argilas}

Após realizada a seleção das 15 amostras de argilas a serem utilizadas como catalisadores para produção do biodiesel através do sistema S1 e S2, foi realizada uma outra seleção dessas argilas baseada nos efeitos verificados em suas propriedades de viscosidade dinâmica das mesmas. O objetivo foi definir quais seriam as duas argilas que apresentariam melhores propriedades catalíticas. $\mathrm{Na}$ figura 63 é apresentado o fluxograma dessa seleção.

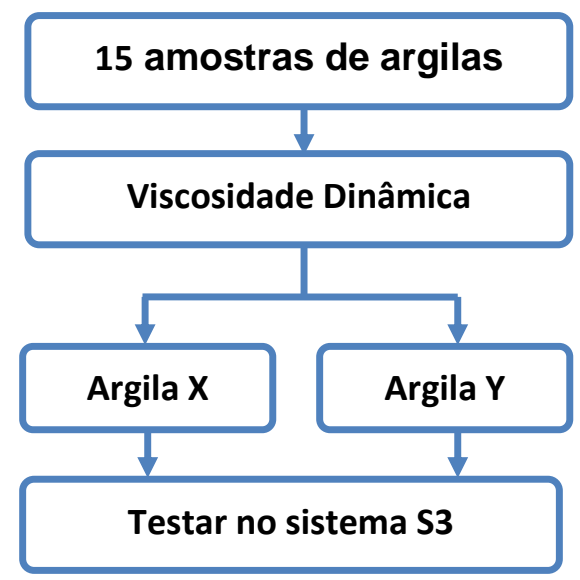

Figura 63: Fluxograma demonstrando a seleção final das argilas.

\section{- Seleção do Óleo Vegetal}

Os procedimentos referentes à preparação da matéria-prima para a sua conversão em biodiesel, visam criar as melhores condições para a efetivação da reação de transesterificação de conversão do biodiesel. Parâmetros como umidade do óleo e acidez, devem ser levados em consideração no processo de produção do biodiesel. Logo, tomando como base os resultados dos trabalhos realizados por Silva (2007), referentes à utilização do óleo de mamona versus soja na catálise heterogênea, optou-se em utilizar para execução desse trabalho o óleo de soja comercial e refinado, vendido nos estabelecimentos comerciais. 


\subsubsection{ETAPA 2- Composições Estudadas}

\section{- Composições Iniciais Estudadas}

Após a seleção das 15 argilas a serem utilizadas como catalisadores na produção do biodiesel, realizada na fase 1 da etapa 1 , foram definidas 15 composições diferentes (listadas na tabela 22), para serem testadas numa etapa posterior nos sistemas S1 e S2. As quantidades utilizadas dos reagentes nas composições permaneceram fixas e foram definidas por Silva (2007): $100 \mathrm{~mL}$ de óleo de soja refinado, $31 \mathrm{~g}$ de álcool etílico anidro e $5 \%$ de catalisador com relação ao óleo, o que diferenciava era o tipo de catalisador (argila). Pretendia-se, com isso, analisar a influência dos catalisadores sobre as propriedades do biodiesel obtido e selecionar as duas melhores argilas/composições para serem testadas e otimizadas posteriormente no sistema S3.

Tabela 22: Composições empregadas no desenvolvimento desta pesquisa.

\begin{tabular}{cccc}
$\begin{array}{c}\text { COMPOSIÇAO } \\
\text { ESTUDADA }\end{array}$ & $\begin{array}{c}\text { AMOSTRAS } \\
\text { SELECIONADAS }\end{array}$ & OLEO/ALCOOL & SISTEMAS UTILIZADOS \\
F1 & A2 & Óleo de Soja + Etanol & S1, S2 \\
F2 & A4 & Óleo de Soja + Etanol & S1, S2 \\
F3 & A12 & Óleo de Soja + Etanol & S1, S2 \\
F4 & A13 & Óleo de Soja + Etanol & S1, S2 \\
F5 & A15 & Óleo de Soja + Etanol & S1, S2 \\
F6 & A16 & Óleo de Soja + Etanol & S1, S2 \\
F7 & A17 & Óleo de Soja + Etanol & S1, S2 \\
F8 & A18 & Óleo de Soja + Etanol & S1, S2 \\
F9 & A19 & Óleo de Soja + Etanol & S1, S2 \\
F10 & A22 & Óleo de Soja + Etanol & S1, S2 \\
F11 & A23 & Óleo de Soja + Etanol & S1, S2 \\
F12 & A24 & Óleo de Soja + Etanol & S1, S2 \\
F13 & A25 & Óleo de Soja + Etanol & S1, S \\
\hline
\end{tabular}


F14

\section{- Otimização das Composições}

Tendo em vista que o sistema S3 é reportado pela literatura como sendo o sistema otimizado e adotado pelo GreenTec - UFRJ para o processo de produção do biodiesel utilizando catalisadores heterogêneos (SILVA, 2007, LIMA, 2008 e SILVA, 2008), foi realizado uma análise mais detalhada das 2 composições selecionadas (argila $\mathrm{X}$ e argila $\mathrm{Y}$ ), bem como uma otimização dessas composições. Todas essas análises foram realizadas no Laboratório de Tecnologias Verdes - GreenTec da Universidade Federal do Rio de Janeiro - UFRJ).

Sabendo que a reação de transesterificação ocorre segundo o esquema da figura 64(a), fixou-se as quantidades dos reagentes: $33 \mathrm{~g}$ de óleo de soja refinado; $10 \mathrm{~g}$ de álcool; 1,8 $\mathrm{g}$ de catalisador, e variou-se o tipo de catalisador (argila $\mathrm{X}$ e argila Y), o tipo de álcool (etanol e metanol), as temperaturas (T) $\left(100^{\circ} \mathrm{C}\right.$ ou $\left.200^{\circ} \mathrm{C}\right) \mathrm{e}$ tempo (t) de reação (30min ou 60min), conforme fluxograma da figura 64(b). Com isso, pretendia-se analisar a influência desses parâmetros sobre as propriedades do biodiesel obtido para posteriormente analisar a eficiência do processo.

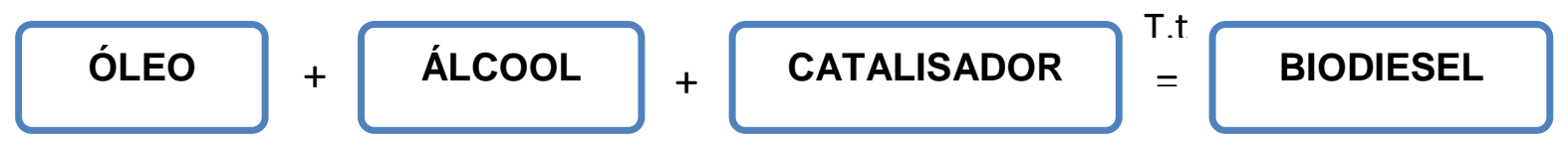

(a)

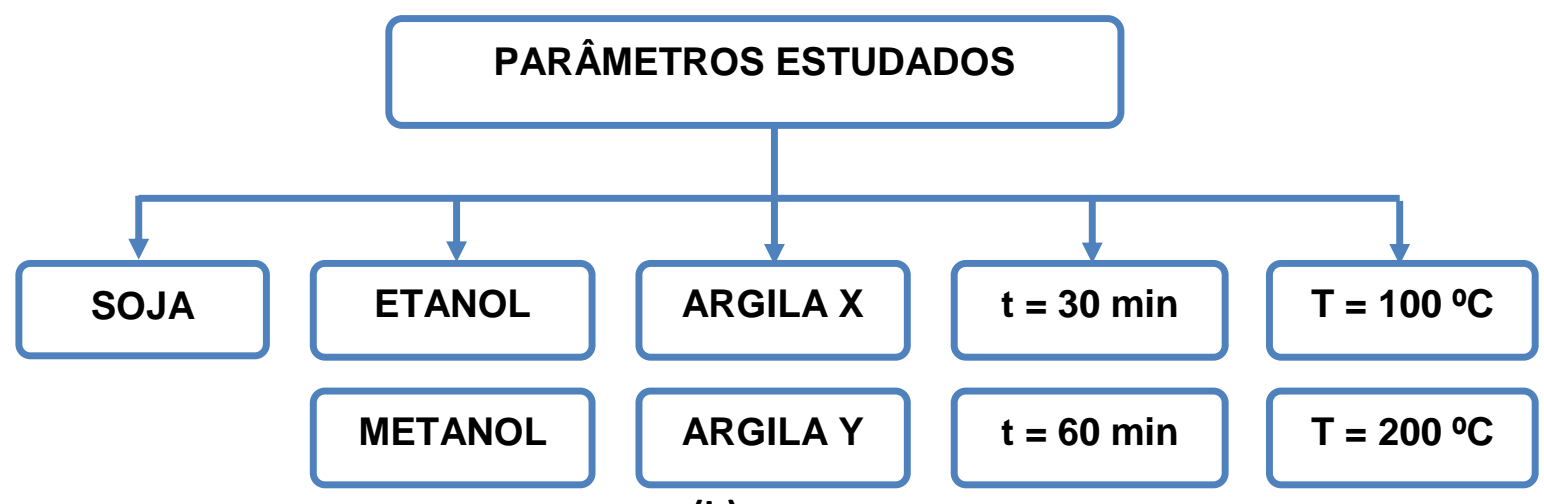

(b)

Figura 64: Fluxogramas: (a) Reação de transesterificação; (b)Variação dos parâmetros da reação. 
$\mathrm{Na}$ tabela 23 são apresentadas as novas composições obtidas através da variação dos parâmetros da reação.

Tabela 23: Novas composições obtidas com óleo de soja e sistema S3.

\begin{tabular}{|c|c|c|c|c|}
\hline $\begin{array}{l}\text { COMPOSIÇÃO } \\
\text { ESTUDADA }\end{array}$ & CATALISADOR & ÁLCOOL & $\mathbf{T}\left({ }^{\circ} \mathbf{C}\right)$ & $t(\mathrm{~min})$ \\
\hline C1 & Argila $X$ & Etanol & 200 & 30 \\
\hline C2 & Argila $X$ & Etanol & 100 & 30 \\
\hline C3 & Argila $X$ & Metanol & 200 & 30 \\
\hline C4 & Argila $X$ & Metanol & 100 & 30 \\
\hline C5 & Argila $X$ & Etanol & 200 & 60 \\
\hline C6 & Argila $X$ & Etanol & 100 & 60 \\
\hline C7 & Argila $X$ & Metanol & 200 & 60 \\
\hline C8 & Argila $X$ & Metanol & 100 & 60 \\
\hline C9 & Argila $Y$ & Etanol & 200 & 30 \\
\hline $\mathrm{C} 10$ & Argila $Y$ & Etanol & 100 & 30 \\
\hline C11 & Argila $Y$ & Metanol & 200 & 30 \\
\hline C12 & Argila $Y$ & Metanol & 100 & 30 \\
\hline C13 & Argila $Y$ & Etanol & 200 & 60 \\
\hline C14 & Argila $Y$ & Etanol & 100 & 60 \\
\hline C15 & Argila $Y$ & Metanol & 200 & 60 \\
\hline C16 & Argila $Y$ & Metanol & 100 & 60 \\
\hline
\end{tabular}

\subsubsection{ETAPA 3 - Sistemas para Preparação do Biodiesel}

Nessa terceira etapa foram desenvolvidos no CPTECH/BENTONISA (Centro de Pesquisas Tecnológicas da BENTONISA) dois sistemas, em escala de laboratório, para o processo de preparação do biodiesel. O objetivo foi analisar o 
melhor sistema S1 ou S2, para posteriormente tentar reproduzir os resultados através do sistema para produção do biodiesel reportado pela literatura (SILVA, 2007, LIMA, 2008 E SILVA, 2008), denominado de sistema S3.

Segue abaixo a descrição detalhada dos sistemas S1, S2 e S3.

\section{a) Sistema S1}

Visando a produção de biodiesel a partir de catalisadores a base de argilas, utilizou-se o sistema S1. O mesmo foi montado e desenvolvido no laboratório do CPTECH/BENTONISA.

Foram testados os 16 catalisadores descritos na tabela 23.

O sistema S1 (figura 65) foi desenvolvido baseado em um dos sistemas de produção do biodiesel utilizado por Silva (2007). O mesmo consta de:

- um agitador/aquecedor Quimis;

- termômetros;

- balão volumétrico com rolhas (reator);

- condensador;

- suportes metálicos;

- conectores de vidro para ajuste do sistema, marca Vidrolabor.

Utilizando o sistema S1, o biodiesel foi preparado a partir do óleo de soja comum, utilizando a via etílica. Em um balão volumétrico com rolhas, utilizou-se $100,0 \mathrm{~g}$ do óleo de soja, 31,0 g de álcool etílico absoluto e 5\% do catalisador (argilas). Essa mistura foi mantida a temperatura oscilante entre $80-100^{\circ} \mathrm{C}$, sob agitação magnética durante 30 minutos. Destaca-se que o tempo de reação só foi contado após a temperatura ser estabilizada em $100^{\circ} \mathrm{C}$.
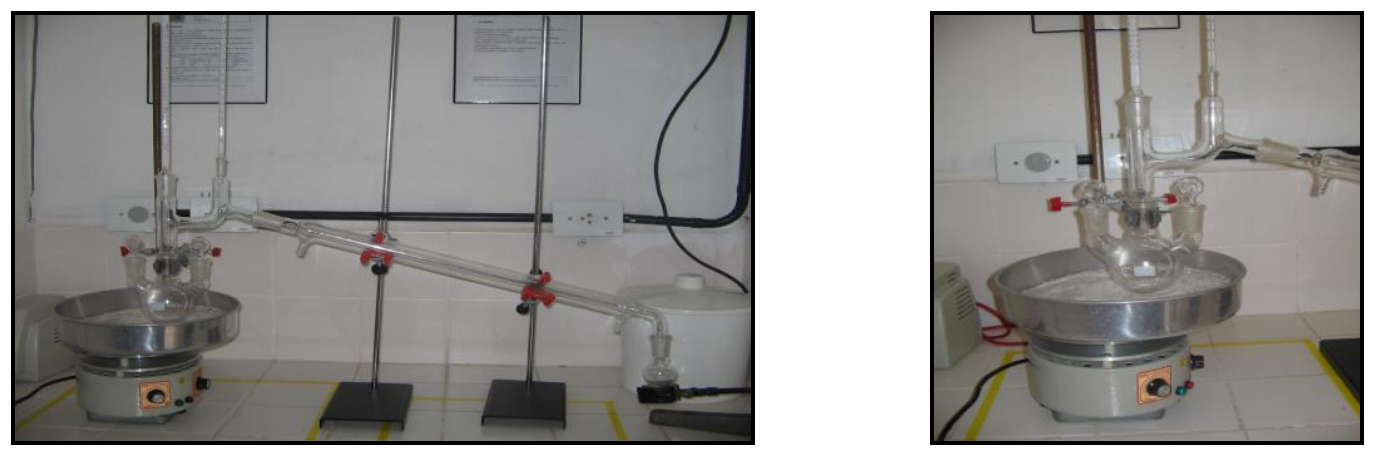

Figura 65: Sistema S1 montado para produção do biodiesel.

Fonte: Adriana Silva, (2008). 
Após a reação, a mistura foi transferida para um funil de separação, onde permaneceu em repouso até ocorrer a separação das fases. A fase superior é o biodiesel e a inferior é a argila. A figura 66 ilustra as duas fases obtidas. A fase superior foi lavada gradativamente com $30 \mathrm{~mL}$ de água aquecida. Este procedimento foi repetido até a retirada de impurezas. Em seguida, o biodiesel purificado foi aquecido a uma temperatura de $105^{\circ} \mathrm{C}$, para remover a água remanescente durante a etapa de lavagem, segundo metodologia descrita por Silva (2007). Após esta etapa o biodiesel foi encaminhado para análise de viscosidade.

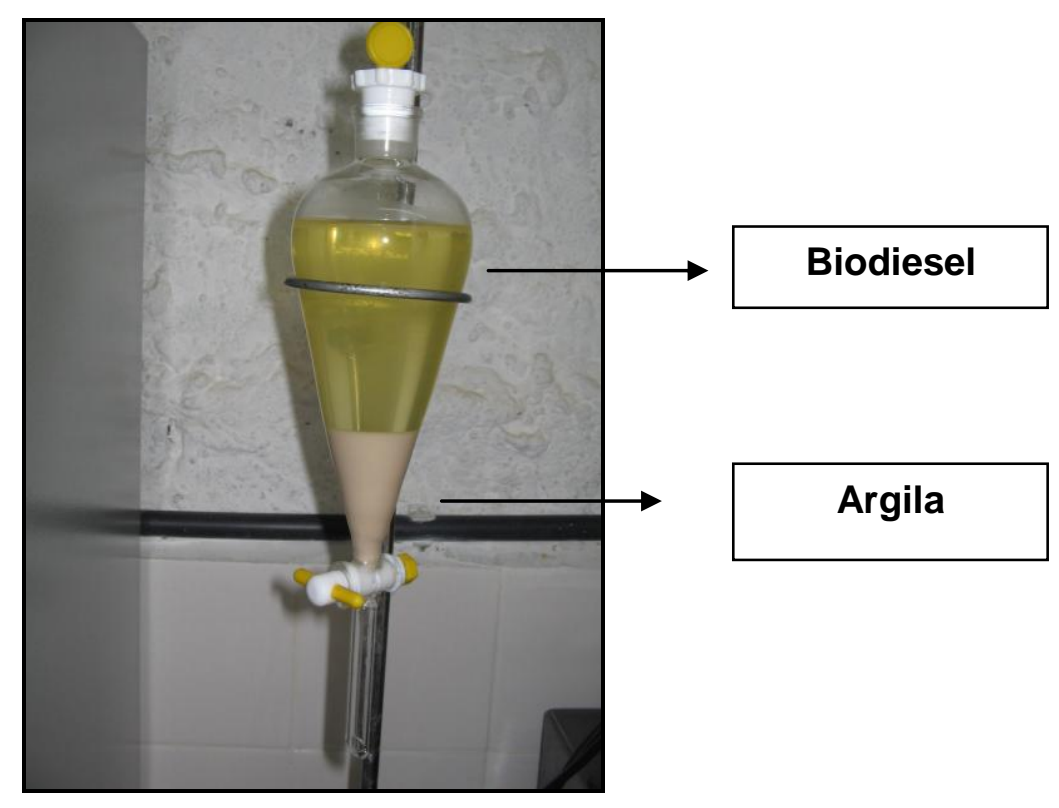

Figura 66: Separação de fases do biodiesel.

Fonte: Adriana Silva, (2008).

\section{b) Sistema S2}

Visando a produção de biodiesel a partir de catalisadores a base de argilas, utilizou-se o sistema S2. O equipamento utilizado no desenvolvimento do sistema 2 , pertence ao CPTECH/BENTONISA.

O sistema S2 permitiu atingir parâmetros de temperatura e pressão superiores ao sistema $\mathrm{S} 1$, o mesmo podia ser ajustado para reproduzir as condições descritas por Silva (2007): agitação mecânica, temperatura controlada, além de um reator que possibilitasse pressurização e aplicação de uma temperatura de $200^{\circ} \mathrm{C}$ (quando utilizou em seus trabalhos o reator PARR 4842). 
O sistema 2 é constituído de um reator em aço inox Fann HDPT, e uma estufa rotativa Fann com controlador digital, ilustrado através da figura 67.
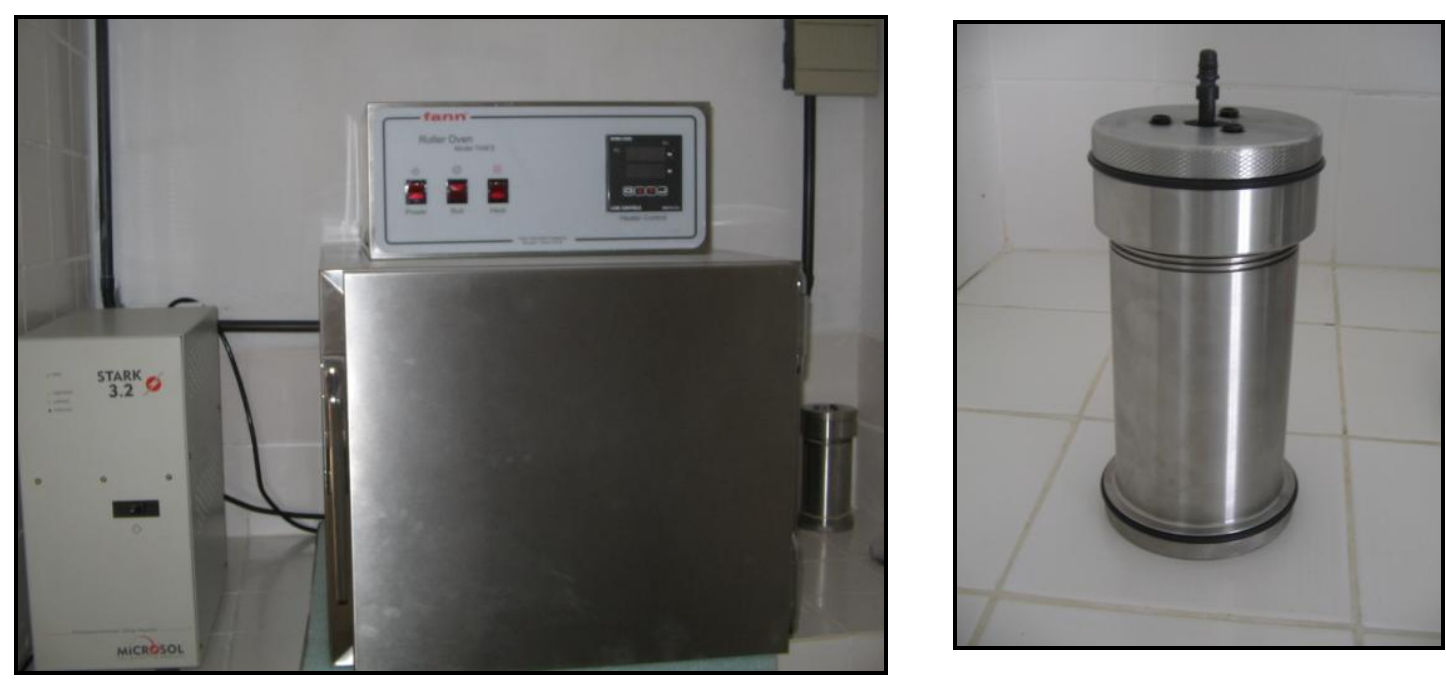

Figura 67: Sistema S2.

Fonte: Adriana Silva, (2008).

A metodologia utilizada no sistema S2 foi: em um béquer foram pesados 100,0 g do óleo de soja comum, 31,0 g do álcool etanol e $5 \mathrm{~g}$ do catalisador (argila), que foram adicionados em um reator Fann HDPT do tipo autoclave, feito de aço inox, com volume útil de $350 \mathrm{~mL}$ e pressão autógena. Após colocar todos os reagentes no reator e fechá-lo com segurança, deu-se início à reação de transesterificação. O reator foi ajustado a uma temperatura de $200^{\circ} \mathrm{C}$, uma pressão autógena do reator de cerca de 2500 Psi, segundo o fabricante. Uma rotação de 500 rpm e um tempo de reação de $30 \mathrm{~min}$. Destaca-se que o tempo de reação só foi contado após a temperatura ser estabilizada em $200^{\circ} \mathrm{C}$.

Depois da reação, a mistura foi colocada em um funil de decantação e deixada por 2 horas (figura 68) até perceber a separação de fases. Em seguida, foi retirada a fase do biodiesel, onde se efetuou a filtração a vácuo, retirando-se os resíduos de catalisador ainda existentes. A fase superior é o biodiesel e a inferior é a argila. A figura 68 ilustra as duas fases obtidas. Foi realizada uma lavagem da fase superior gradativamente com $30 \mathrm{~mL}$ de água aquecida. Após a filtração, o biodiesel foi colocado de volta em um balão de decantação para efetuar outra etapa de lavagem, onde foram adicionadas $20 \%$ de água destilada em relação ao volume do 
biodiesel, à temperatura ambiente. Este processo foi repetido até que a água de lavagem não estivesse mais básica, identificada com gotas de fenolftaleína.

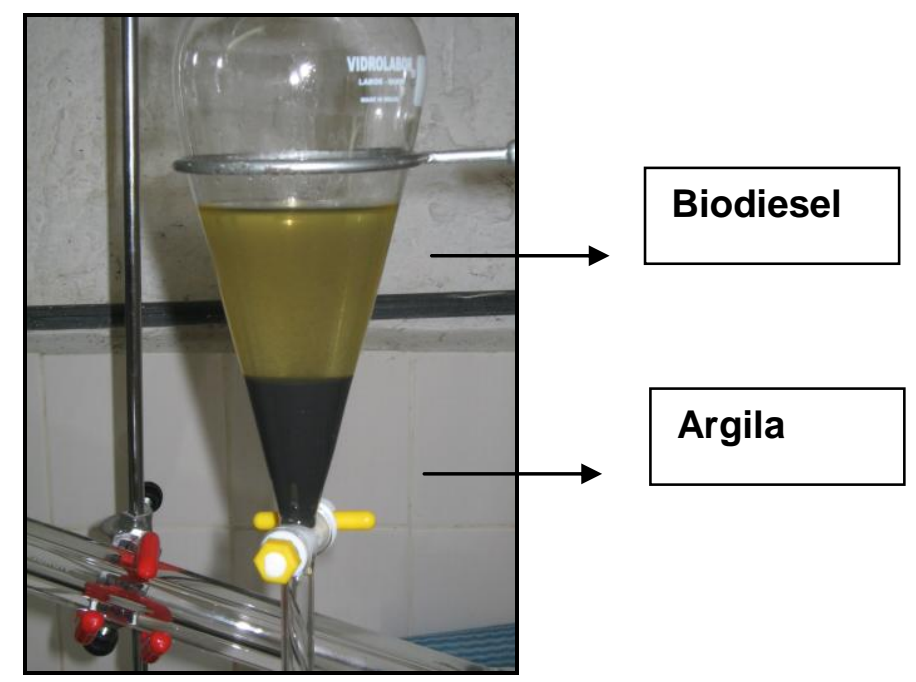

Figura 68: Separação de fases do biodiesel.

Fonte: Adriana Silva, (2008).

Em seguida, o biodiesel foi colocado em uma chapa aquecedora (figura 69) a uma temperatura variando entre $100^{\circ} \mathrm{C}-110^{\circ} \mathrm{C}$, durante 10 minutos, para retirar a água existente durante a etapa de purificação. Após esta etapa o biodiesel foi encaminhado para análise de viscosidade.

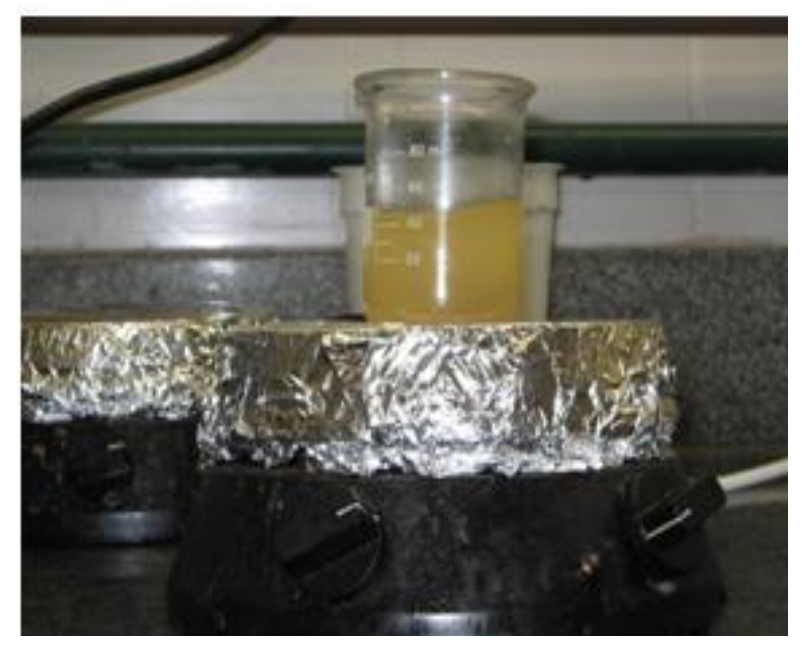

Figura 69: Aquecimento do biodiesel.

Fonte: Adriana Silva, (2008). 


\section{c) Sistema S3}

O sistema S3 (figura 70) foi utilizado por Silva (2007), Lima (2008) e Silva (2008). A preparação do biodiesel utilizando o sistema S3 e catalisadores heterogêneos foi realizada no Laboratório de Tecnologias Verdes - GreenTec da Universidade Federal do Rio de Janeiro - UFRJ.

O procedimento utilizado para produção do biodiesel utilizando o sistema S3 constou de: em um béquer foi pesado $33,0 \mathrm{~g}$ do óleo de soja comum, 10,0 $\mathrm{g}$ do álcool etanol ou metanol e 1,8 $\mathrm{g}$ do catalisador, que foram adicionados em um reator PARR 4842 do tipo autoclave, feito de aço inox, com volume útil de $300 \mathrm{~mL}$ e pressão máxima de trabalho $2.109 .209 \mathrm{Kg} / \mathrm{m}^{2}$. O equipamento possui um tubo para retirada de amostras, bem como um sistema de agitação e manta externa para aquecimento. Após colocar todos os reagentes no reator e fechá-lo com segurança, deu-se início a reação de transesterificação.

O reator foi ajustado a uma temperatura de $100^{\circ} \mathrm{C}$ ou $200^{\circ} \mathrm{C}$, uma pressão de $14.061,39 \mathrm{Kg} / \mathrm{m}^{2}$, rotação de $500 \mathrm{rpm}$ e tempo de reação de $30 \mathrm{~min}$ ou $60 \mathrm{~min}$. Destaca-se que o tempo de reação só foi contado após a temperatura ser estabilizada em $100^{\circ} \mathrm{C}$ ou $200^{\circ} \mathrm{C}$.

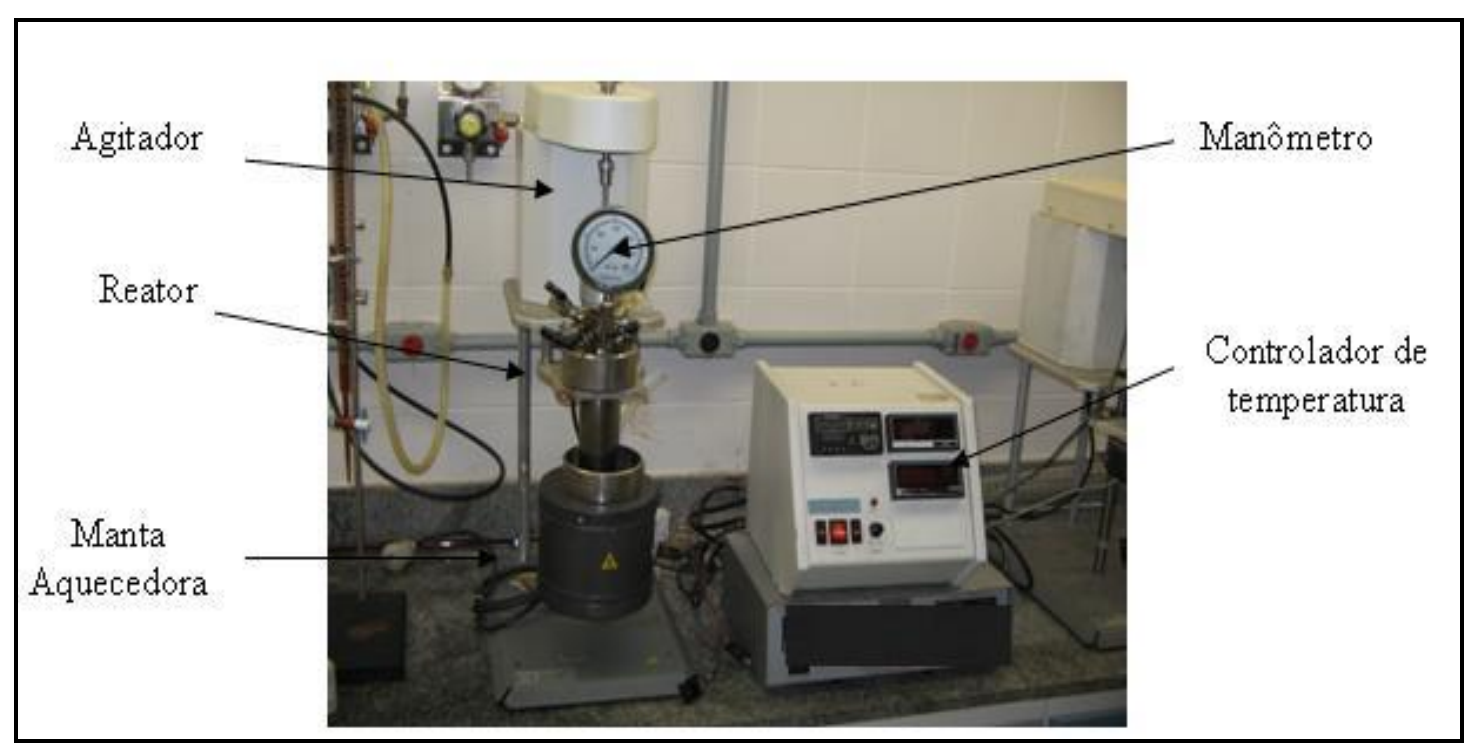

Figura 70: Equipamento para a produção de biodiesel composto de: Reator PARR 4842, manômetro, agitador e sistema de aquecimento.

Fonte: Adriana Silva, (2008). 
Depois que a reação foi finalizada, o reator foi aberto, a mistura foi colocada em um balão de decantação e deixada por 2 horas até perceber a separação de fases, em seguida foi retirada a fase menos densa (biodiesel) onde efetuou-se a filtração a vácuo, retirando-se os resíduos de catalisador ainda existentes.

Após a filtração, o biodiesel foi colocado de volta em um balão de decantação para efetuar a etapa de lavagem, onde foram adicionadas $20 \%$ de água destilada em relação ao volume do biodiesel, à temperatura ambiente. Este processo foi repetido até que a água de lavagem não estivesse mais básica, identificada com gotas de fenolftaleína. Em seguida, o biodiesel foi colocado em uma chapa aquecedora a uma temperatura de $110^{\circ} \mathrm{C}$, durante 10 minutos, para retirar a água existente durante a etapa de purificação. Após esta etapa o biodiesel foi encaminhado para análises.

Foram realizadas as análises de viscosidade, glicerina livre e total e cromatografia gasosa no Laboratório de Tecnologias Verdes - GreenTec da Universidade Federal do Rio de Janeiro - UFRJ.

\subsubsection{ETAPA 4 - Caracterização das Amostras de Argilas Selecionadas}

$\mathrm{Na}$ quarta etapa foi realizada uma caracterização físico-química e mineralógica para os materiais argilosos considerados promissores para produção do biodiesel (AX e AY), através das seguintes técnicas:
a) Fluorescência de raios $X(F R X)$;
b) Difração de raios $X(D R X)$;
C) Espectroscopia na região do infravermelho(IV);
d) Microscopia eletrônica de Varredura(MEV);
e) Espectroscopia de Dispersão de raios X(EDX);
f) Análise Textural(método)BET.

\subsubsection{ETAPA 5 - Caracterização do Óleo de Soja e do Biodiesel}

A quinta etapa constou da descrição dos métodos de caracterização do óleo de soja e do biodiesel obtido. 
Foram realizadas as seguintes caracterizações no óleo de soja: composição química, umidade, índice de acidez, densidade $20^{\circ} \mathrm{C}$, glicerol total e viscosidade $40^{\circ} \mathrm{C}$.

Para caracterização do biodiesel obtido, utilizou-se as seguintes técnicas: composição química, umidade, índice de acidez, viscosidade cinemática, teor de éster, teor de álcool e cromatografia gasosa.

\subsubsection{RESULTADOS OBTIDOS}

\subsubsection{PARTE 1: SELEÇÃO DAS ARGILAS}

Para a realização deste trabalho escolheu-se dentre as 27 amostras de argilas um total de 15 argilas a serem testadas como catalisadores para produção de biodiesel. Selecionou-se 5 tipos de argilas na forma "in natura", 4 tipos de argilas na forma sódica, 4 tipos de argilas na forma ácida e 2 tipos de argilas na forma tratadas termicamente. O critério utilizado para essa escolha foi: selecionar as amostras de argilas que apresentassem um menor valor na análise de teor de umidade e um $\mathrm{pH}$ próximo de 7.

$\mathrm{Na}$ tabela 24 foram apresentados os resultados das amostras de argilas para as análises de teor de umidade e $\mathrm{pH}$. A partir da tabela 24 foi possível verificar que na coluna 2 encontram-se descritas as 27 amostras de argilas fornecidas pela empresa BENTONISA para esse estudo. Na coluna 3 estão os resultados de teor de umidade para as amostras de argilas e na coluna 4, estão os resultados das análises de $\mathrm{pH}$.

Tabela 24: Resultados das análises de teor de umidade e pH.

\begin{tabular}{cccc} 
TIPOS & AMOSTRAS & TEOR DE UMIDADE (\%) & pH \\
& A1 & 7,33 & 8,2 \\
"in natura" & A2 & 3,58 & 7,7 \\
& A3 & 7,57 & 6,9 \\
& A4 & 3,88 & 7,9 \\
\hline
\end{tabular}




\begin{tabular}{|c|c|c|c|}
\hline & A5 & 9,58 & 7,9 \\
\hline & A6 & 7,48 & 8,4 \\
\hline & A7 & 10,34 & 7,9 \\
\hline & A8 & 9,00 & 7,0 \\
\hline & A9 & 6,93 & 8,1 \\
\hline & A10 & 7,00 & 8,6 \\
\hline & A11 & 8,88 & 8,4 \\
\hline & A12 & 4,97 & 8,1 \\
\hline & A13 & 4,59 & 7,7 \\
\hline & A14 & 6,41 & 8,1 \\
\hline & A15 & 0,49 & 4,9 \\
\hline \multirow{6}{*}{ Sódicas } & A16 & 10,19 & 10,0 \\
\hline & A17 & 9,62 & 9,8 \\
\hline & A18 & 9,05 & 9,6 \\
\hline & A19 & 8,86 & 10,5 \\
\hline & A20 & 11,79 & 11,0 \\
\hline & A21 & 10,98 & 10,9 \\
\hline \multirow{4}{*}{ Ácidas } & A22 & 4,80 & 3,2 \\
\hline & A23 & 5,30 & 3,1 \\
\hline & A24 & 4,30 & 4,0 \\
\hline & A25 & 5,40 & 4,1 \\
\hline \multirow{2}{*}{$\begin{array}{c}\text { Tratadas } \\
\text { termicamente }\end{array}$} & A26 & 0,38 & 5,0 \\
\hline & A27 & 0,30 & 5,3 \\
\hline
\end{tabular}

Para a análise de teor de umidade (TU), verificou-se que: as argilas "in natura" apresentaram em geral um valor na faixa de $7 \%$, as argilas "sódicas" na faixa de $10 \%$, as argilas ácidas na faixa de $5 \%$ e as tratadas termicamente na faixa de $0,3 \%$.

O teor de umidade foi uma análise realizada neste trabalho visando selecionar os materiais argilosos que apresentavam um menor valor, ou seja, esse resultado representaria uma menor quantidade de água contida nos espaços interlamelares dessas argilas, havendo portanto, uma mínima influência da água na reação de transesterificação. Diante do exposto, foi possível verificar que, dentre as amostras listadas na tabela 24, apresentaram um baixo teor de umidade as argilas do tipo 
"ácidas e as tratadas termicamente"; resultado já esperado, pois durante o processo de acidificação da argila ocorre modificações estruturais a depender do método de ativação. Esse processo gerou a perda de água contida entre as lamelas da argila, produzindo assim catalisadores com alta acidez, alta área específica, alta porosidade e termicamente estáveis (RODRIGUES, et. al., 2006). Para as argilas tratadas termicamente, o processo de elevação de temperatura também gerou a perda de água contida entre as lamelas da argila.

Através da análise de $\mathrm{pH}$, verificou-se que as argilas "in natura" apresentaram em geral um $\mathrm{pH}$ na faixa de 8 , já as amostras sódicas na faixa de 10, as argilas ácidas na faixa de 4 e as tratadas termicamente apresentaram em geral um $\mathrm{pH}$ na faixa de 5. Mediante esse resultado, verificou-se que as argilas "ácidas e tratadas termicamente" poderão ser utilizadas como catalisadores ácidos nas reações de transesterificação, tendo em vista que argilas modificadas por tratamentos químicos e térmicos aumentam a atividade catalítica e adsorvente (RODRIGUES, et. al., 2006).

Logo, as amostras escolhidas para realização dessa pesquisa foram:

- Para as argilas "in natura", selecionou-se as amostras: A2, A4, A12, A13, além da amostra A15, que trata-se de um caulim o qual servirá como referencial comparativo para os materiais tratados termicamente a $600^{\circ} \mathrm{C}$ e $1000^{\circ} \mathrm{C}$;

- Para as argilas sódicas, selecionou-se a argila sódica natural (A16), que servirá como padrão comparativo para as argilas sódicas ativadas industrialmente. Baseado então na análise de teor de umidade (menor teor), selecionou-se as amostras de argilas sódicas ativadas industrialmente : A17, A18 e A19;

- Para as argilas ácidas, foi verificada a importância de trabalhar com todas as amostras (A22, A23, A24 e A25), justificativas já mencionadas anteriormente através dos resultados de $\mathrm{TU}$ e $\mathrm{pH}$;

- Para as argilas tratadas termicamente, também foi verificada a importância de trabalhar com todas as amostras (A26 e A27), fato comentado anteriormente através dos resultados de $\mathrm{TU}$ e $\mathrm{pH}$; 


\subsubsection{PARTE 2: ANÁLISE DOS SISTEMAS S1 E S2 E ESCOLHA DAS MELHORES COMPOSIÇÕES}

Inicialmente serão descritos os resultados dos ensaios de cor do óleo (aspecto visual) e viscosidade para em seguida ser analisado o sistema mais adequado para essa aplicação (produção do biodiesel utilizando catalisadores a base de argilas). Baseado nesses resultados será possível escolher os catalisadores que nas composições apresentaram melhores propriedades.

\subsection{COR DO ÓLEO}

A tabela 25 mostra os resultados visuais comparativos obtidos para os sistemas S1 e S2. O objetivo dessa análise foi verificar visualmente se houve modificações na coloração do óleo de soja após ser submetido aos processos do sistema S1 e S2. Ocorrendo essas modificações, esse será um resultado que possivelmente indique a ocorrência de reações no óleo, podendo ter ocorrido inclusive reação de transesterificação, o que indicaria formação do biodiesel. Essa foi uma metodologia desenvolvida pelo CPTECH/BENTONISA.

Tabela 25: Resultados para as composições F1-F15, ilustrando o aspecto visual da cor do óleo obtidos através da utilização do sistema S1 e S2.

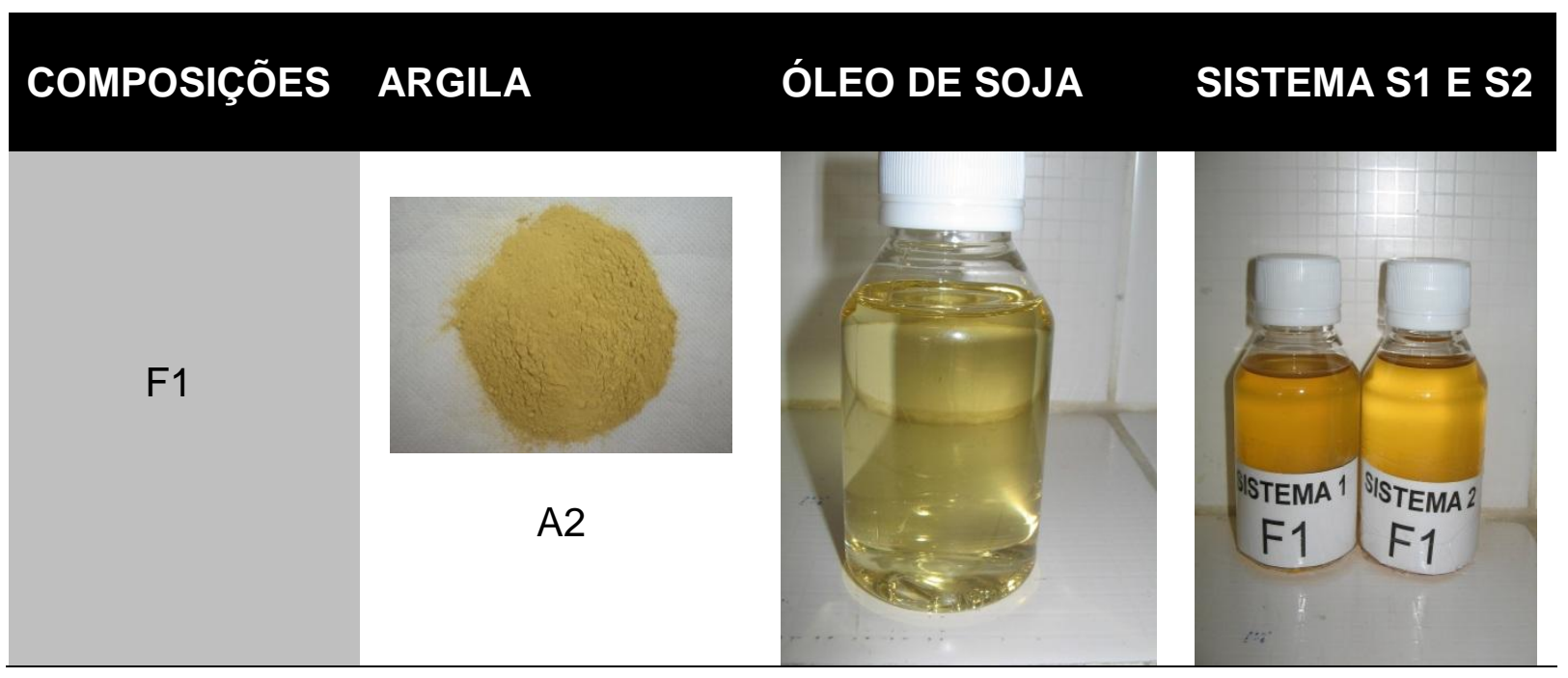




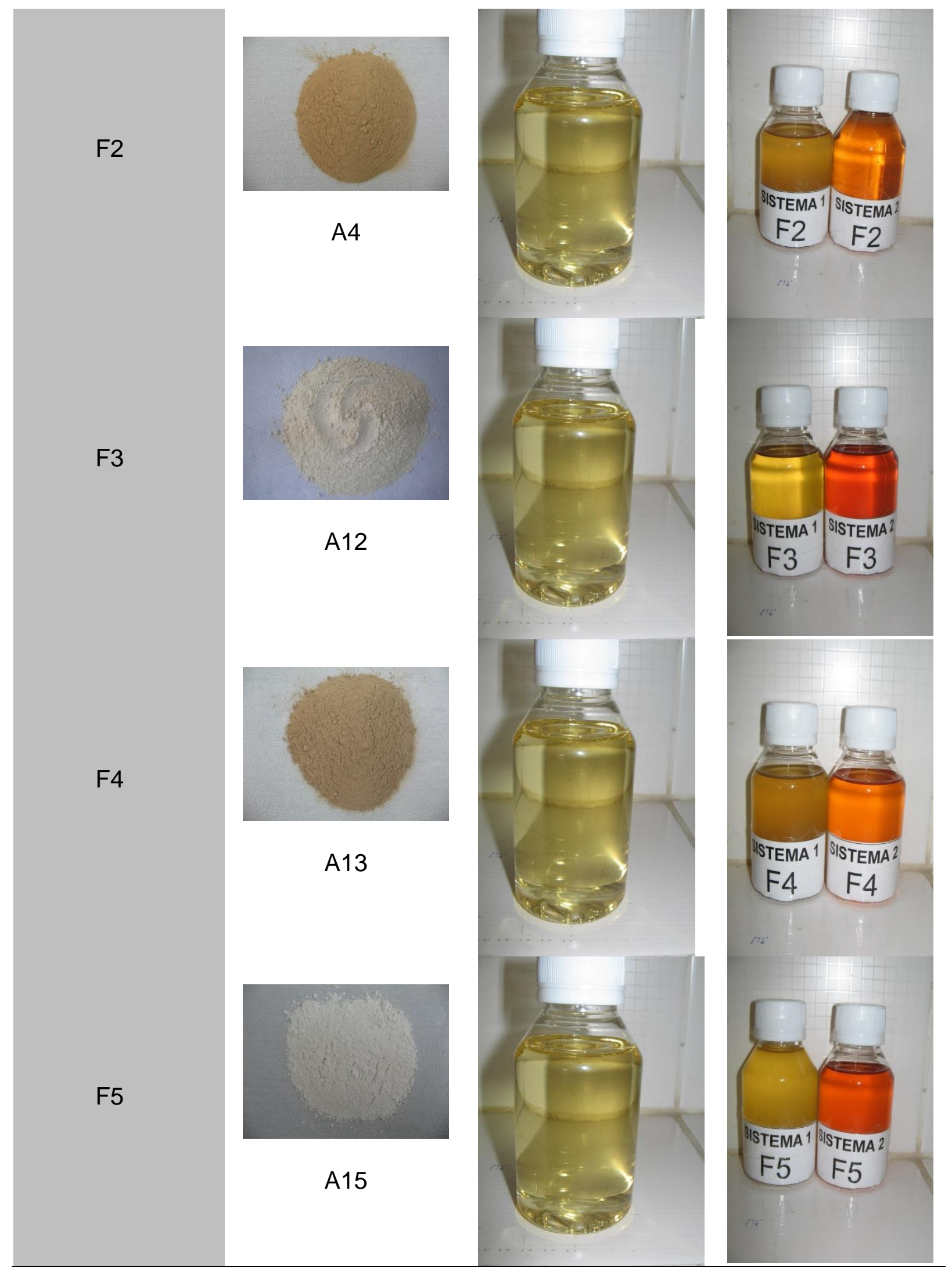




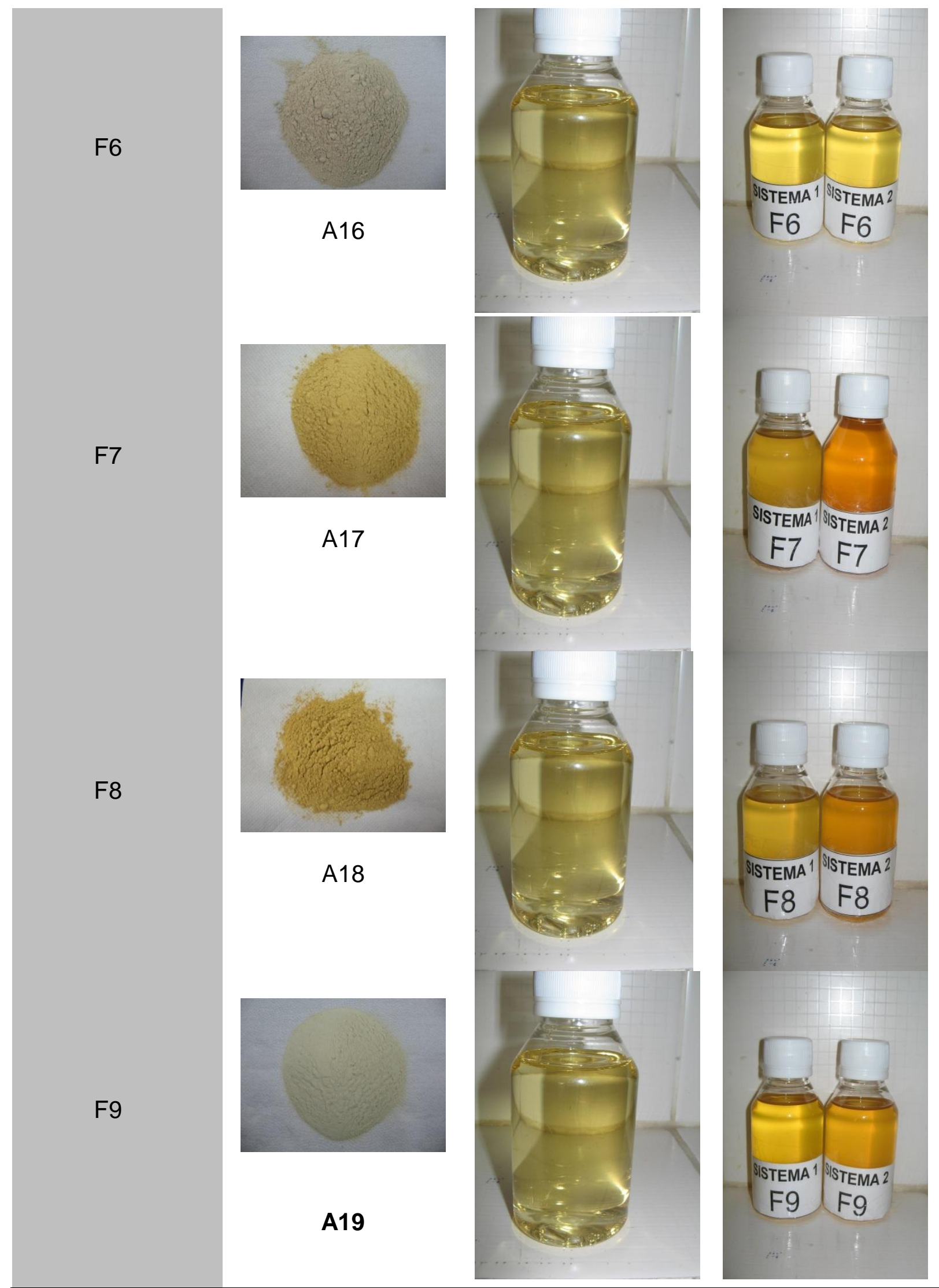




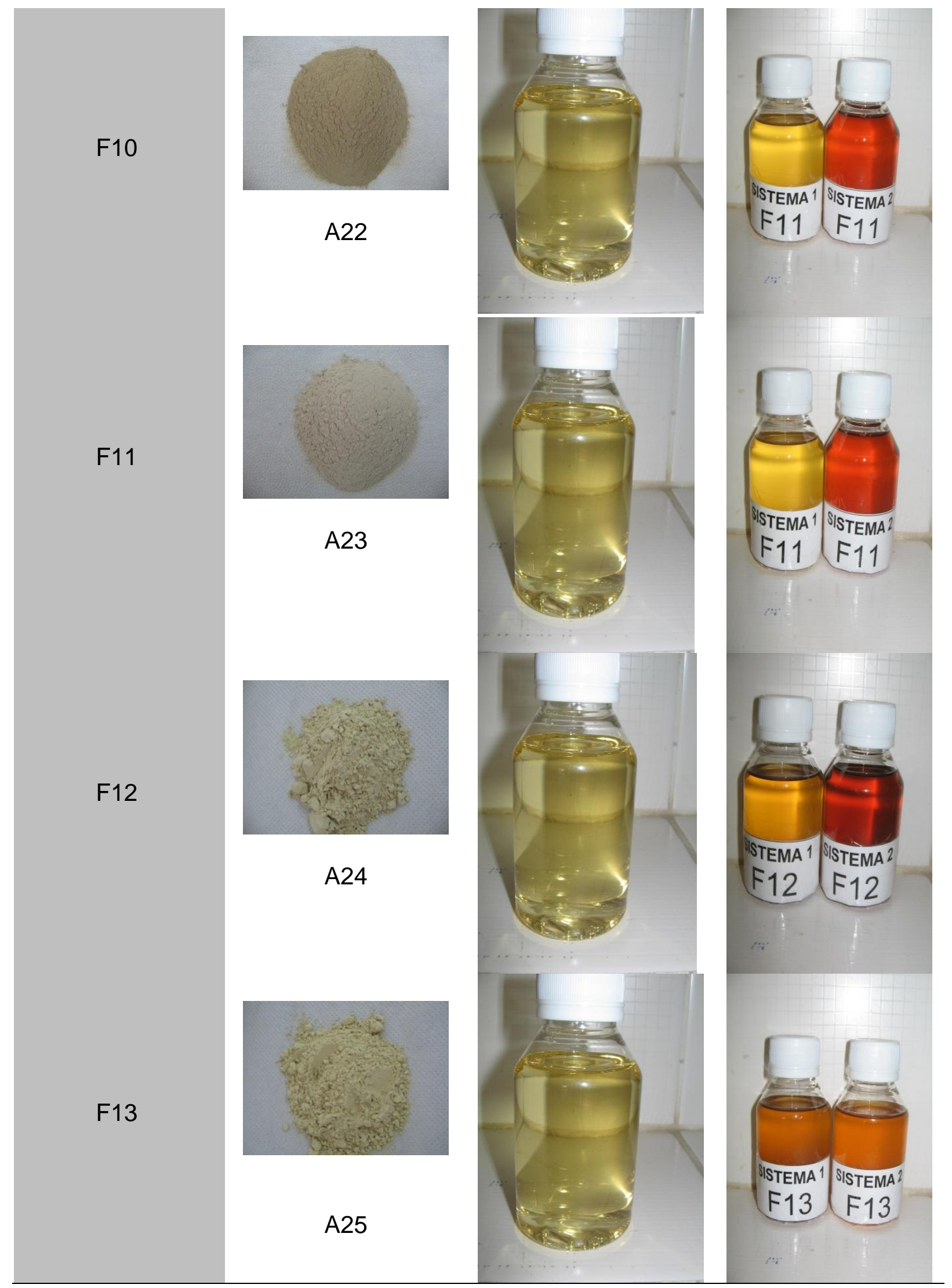




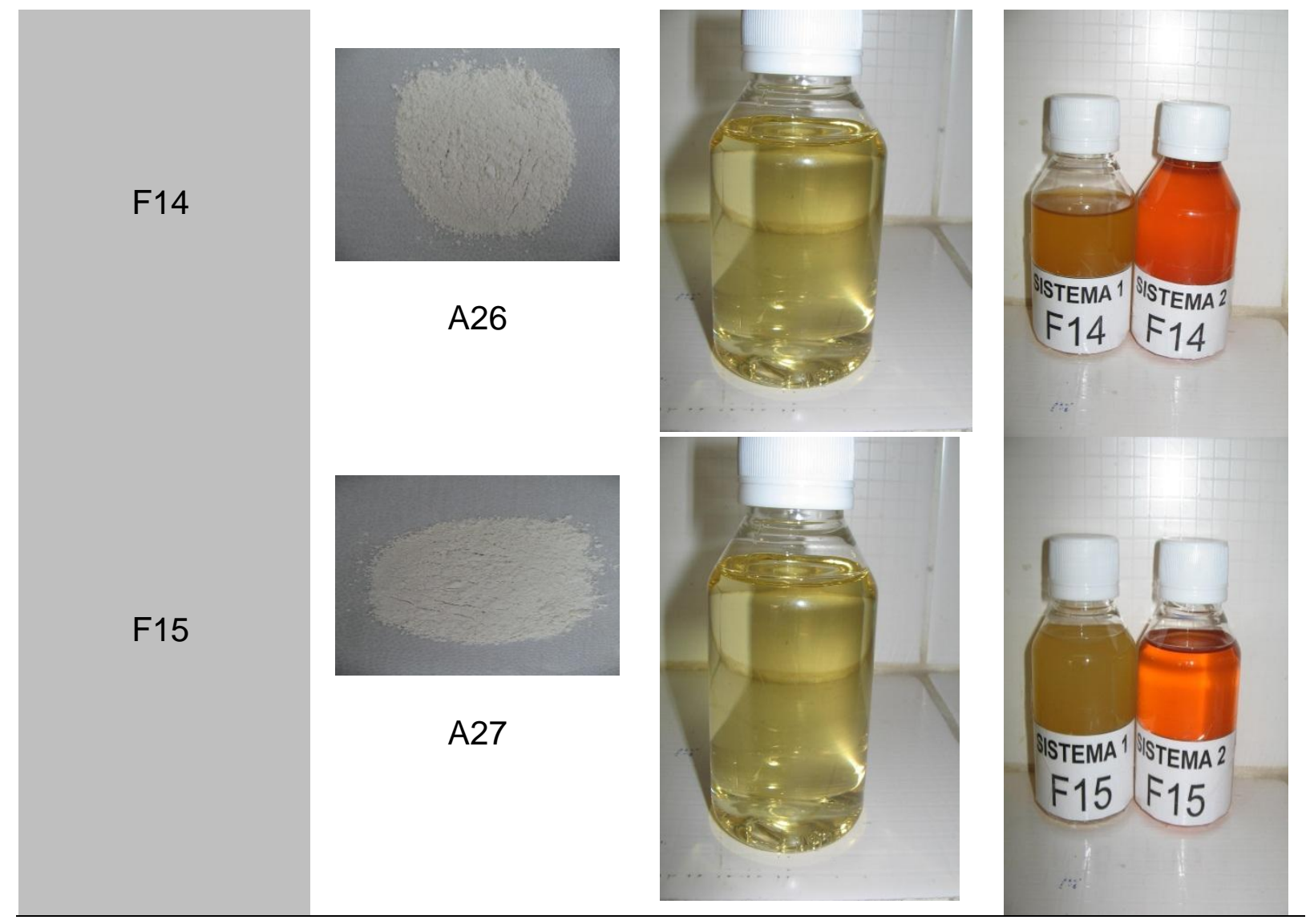

A partir da tabela 25 foi possível verificar na coluna 1 as composições selecionadas, descritas com detalhes na tabela 24. A coluna 2, ilustra com fotografias as 15 argilas (cores diferenciadas) utilizadas. Na coluna 3 está a amostra do óleo de soja comercial (não submetida a nenhum dos sistemas), onde sua cor do óleo servirá como padrão comparativo para as amostras submetidas aos sistemas S1 e S2. Por fim, na coluna 4 estão ilustrados os resultados comparativos para as amostras submetidas aos sistemas $\mathrm{S} 1$ e $\mathrm{S} 2$.

Analisando visualmente os resultados da tabela 25 é possível verificar uma diferença de coloração entre o produto inicial (coluna 3) e no produto final (coluna 4) para todas as amostras. Além disso, percebeu-se que as amostras quando submetidas ao sistema S2 apresentaram cores do óleo mais escuras do que as amostras submetidas ao sistema $\mathrm{S} 1$, o que sugere a ocorrência de reação de transesterificação, com taxa de conversão óleo em biodiesel, apenas para as amostras do sistema S2. Esse fato pode ser explicado levando-se em consideração que o sistema S1 não atingiu os parâmetros de temperatura e pressão descritos por Silva (2007), enquanto o sistema S2 conseguiu reproduzir essas condições. 
Outro provável motivo para explicar essa diferença de coloração no óleo seria a existência da influência dos diferentes catalisadores utilizados na reação, tornando-se presumível que os catalisadores quando submetidos à determinada temperatura e pressão não conseguiram converter o óleo em biodiesel. Cabe salientar também, que os parâmetros de temperatura e pressão descritos por Silva (2007) que foram reproduzidos neste experimento, não avaliam se o óleo sofreu degradação, já que a uma temperatura de $200^{\circ} \mathrm{C}$ é possível que o óleo de soja tenha degradado, ou até mesmo tenha ocorrido a formação de polímeros.

Segundo Galvão (2007), óleos vegetais que contêm triacilgliceróis de estrutura predominantemente insaturada, reações de oxidação podem ser observadas até a temperatura ambiente e o aquecimento a temperaturas próximas a 250ㄷ ocasionando reações complementares de decomposição térmica, cujos resultados podem inclusive levar a formação de compostos poliméricos mediante reações de condensação.

\subsection{VISCOSIDADE}

Estudos reológicos foram realizados para medir a viscosidade dinâmica dos biodieseis obtidos a partir das composições de F1 - F15 quando submetidas aos sistemas S1 e S2. A tabela 26 mostra os resultados das viscosidades dinâmicas.

Tabela 26: Referente às viscosidades dinâmicas das amostras no sistema S1 e S2.

\begin{tabular}{ccc} 
Composições & $\begin{array}{c}\text { Sistema 1 } \\
\text { Cp (mPa.s) }\end{array}$ & $\begin{array}{r}\text { Sistema 2 } \\
\text { Cp (mPa.s) }\end{array}$ \\
\hline F1 & 63,5 & 54,3 \\
F2 & 61,9 & 53,7 \\
F3 & 60,5 & 56,0 \\
F4 & 62,9 & 56,2 \\
F5 & 53,1 & 55,7 \\
F6 & 53,7 & 55,2 \\
F7 & 61,2 & 53,0 \\
F8 & 53,5 & 56,1 \\
F9 & 55,1 & 53,9 \\
F10 & 54,2 & 56,4 \\
\hline
\end{tabular}




\begin{tabular}{lll} 
F11 & 55,0 & 37,6 \\
F12 & 49,1 & 26,5 \\
F13 & 55,5 & 103,2 \\
F14 & 54,6 & 94,8 \\
F15 & 54,5 & 46,9 \\
\hline
\end{tabular}

A fim de monitorar quais amostras seriam candidatas a bons catalisadores, foi tomado como critério a viscosidade do biodiesel que mais se aproximasse da viscosidade do óleo de soja. Foi então medida inicialmente a viscosidade dinâmica do óleo de soja utilizado nas 15 composições, obtendo-se então o valor de $\mathrm{Cp}=59,9$ mPa.s.

Para o sistema S1, verificou-se que o resultado não foi apreciável, devido ao seu processo de obtenção não satisfazer as condições previstas por Silva (2007). Foi observado que as viscosidades de todas as amostras do sistema S1 não diferem muito da viscosidade do óleo de soja. Para o sistema S2, observou-se que as amostras F11 e F12 apresentaram melhor resultado, pois tal sistema foi reproduzido em condições de temperatura e pressão como reportado por Silva (2007). É importante também citar que as amostras F13 e F14 do sistema S2 aumentaram bastante suas viscosidades ao comparar com a viscosidade do óleo de soja. Tal efeito pode ser explicado pelo aquecimento aplicado nas amostras, que ocasionou reações complementares de decomposição térmica, levando à formação de compostos poliméricos, como explica Galvão (2007).

Diante dos resultados expostos nas tabelas, foram selecionadas as composições $\mathrm{F} 11$ e F12 submetidas ao sistema S2 como aquelas que apresentaram um resultado bastante interessante quando comparadas com as demais, já que suas viscosidades diminuíram consideravelmente, tomando como padrão a viscosidade do óleo de soja. Dessa forma pode-se sugerir que provavelmente a transesterificação ocorreu.

Tendo em vista que o sistema S2 (desenvolvido no $\mathrm{CPTECH}$ ) foi utilizado com o objetivo de reproduzir as condições apresentadas pelo o sistema S3 (da UFRJ), cabe agora, utilizar o sistema S3, que é reportado pela literatura como sendo o sistema padrão para o processo de produção do biodiesel utilizando catalisadores heterogêneos (utilizado por SILVA 2007, LIMA 2008 e SILVA 2008), para reproduzir os resultados obtidos com o sistema $\mathrm{S} 2$. 
Pretende-se, nas próximas seções, realizar uma análise mais detalhada das composições F11 e F12 (argilas A23 - Trata-se da bentonita Bofe acidificada em laboratório e A24 - Trata-se de uma bentonita comercial ácida ), visando determinar quanto desses catalisadores argilosos converte óleo em biodiesel, com o auxílio da técnica de cromatografia gasosa. Além disso, foi também realizada uma otimização dos parâmetros reacionais, visando analisar a influência dos mesmos na reação de transesterificação durante a produção de biodiesel.

\subsubsection{PARTE 3: CARACTERIZAÇÃO DOS CATALISADORES SELECIONADOS}

Os catalisadores argilosos A23 e A24 foram caracterizados através das seguintes técnicas: $F R X$ - Fluorescência de raios $X ; D R X$ - Difração de raios $X$; IV - Espectroscopia na Região do Infravermelho; MEV- Microscopia Eletrônica de Varredura; EDX- Espectroscopia de Dispersão de raios X e BET- Análise Textural.

\subsection{DIFRAÇÃO DE RAIOS X}

A caracterização das amostras por difração de raios $X$, visou verificar a existência de minerais acessórios, bem como, a identificação de argilominerais presentes no material. As figuras 71 e 72 mostram as curvas de difração de raios $\mathrm{X}$ para as amostras de catalisadores A23 e A24, as mesmas foram fornecidas para essa pesquisa pela empresa BENTONISA e são argilas comerciais ácidas.

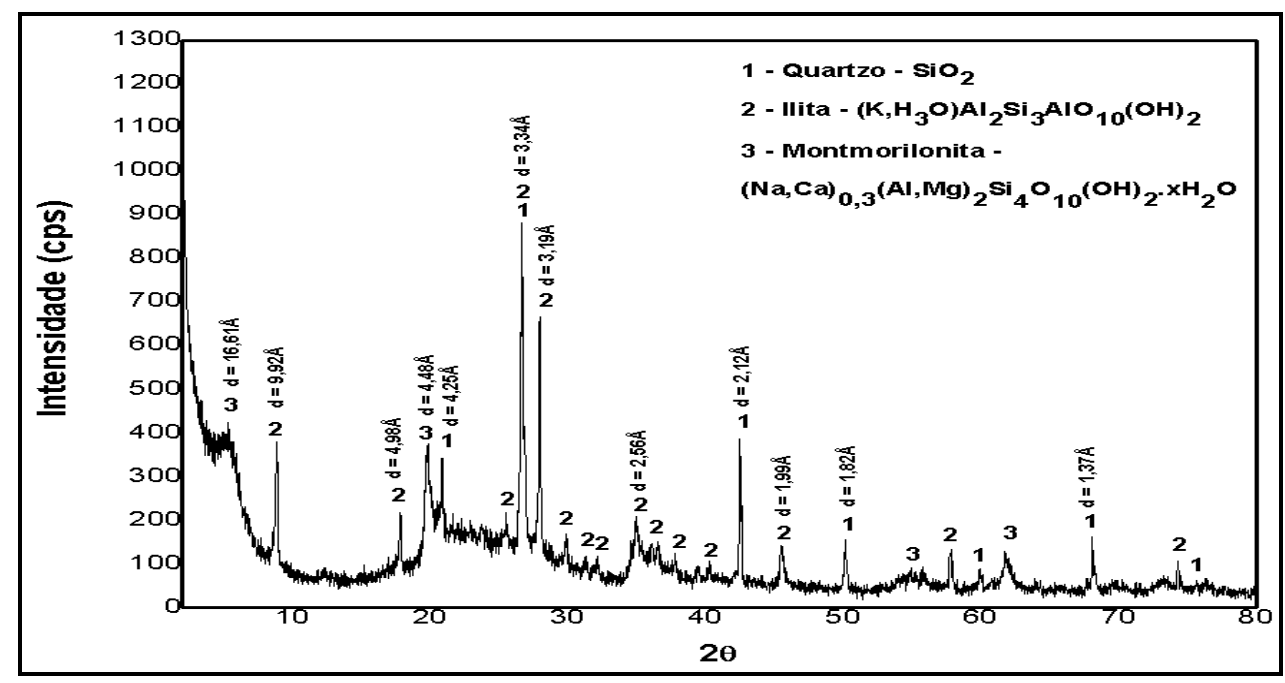

Figura 71: Curva de raios $\mathrm{X}$ para argila $\mathrm{A} 23$. 
Analisando a curva de raios $X$ da figura 71 , observou-se a presença de três fases em sua estrutura: a fase quartzo de fórmula $\mathrm{SiO}_{2}$, como também a fase ilita de fórmula $\left(\mathrm{KH}_{3} \mathrm{O}\right) \mathrm{Al}_{2} \mathrm{Si}_{3} \mathrm{AlO}_{10}(\mathrm{OH})_{2}$, e por fim a fase montmorillonita de fórmula $(\mathrm{NaCa})_{0,3}(\mathrm{AlMg})_{2} \mathrm{Si}_{4} \mathrm{O}_{10}(\mathrm{OH})_{2} \mathrm{XH}_{2} \mathrm{O}$. Observou-se ainda, uma reflexão do grupo da esmectítica (E), do argilomineral montmorilonítico, que corresponde a distância basal

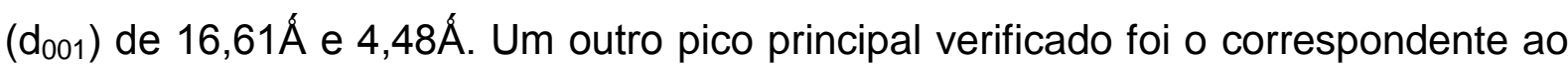

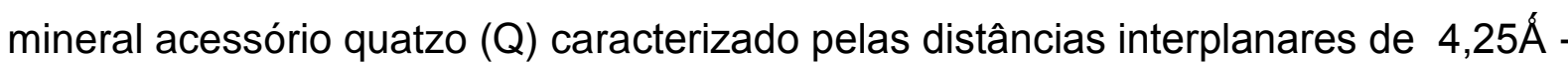
$3,34 \AA \hat{~ e ~ o ~ d a ~ i l i t a ~(I) ~ c a r a c t e r i z a d o ~ p e l a s ~ d i s t a ̂ n c i a s ~ i n t e r p l a n a r e s ~ c a r a c t e r i ́ s t i c a s ~ d e ~}$ $9,92 \AA$ - $-3,34$ Á. Esses resultados estão de acordo com a literatura (SOUZA SANTOS, 1992).

Para a curva de raios $X$ da argila A24 (figura 72) observou-se a presença de quatro fases sem sua estrutura.

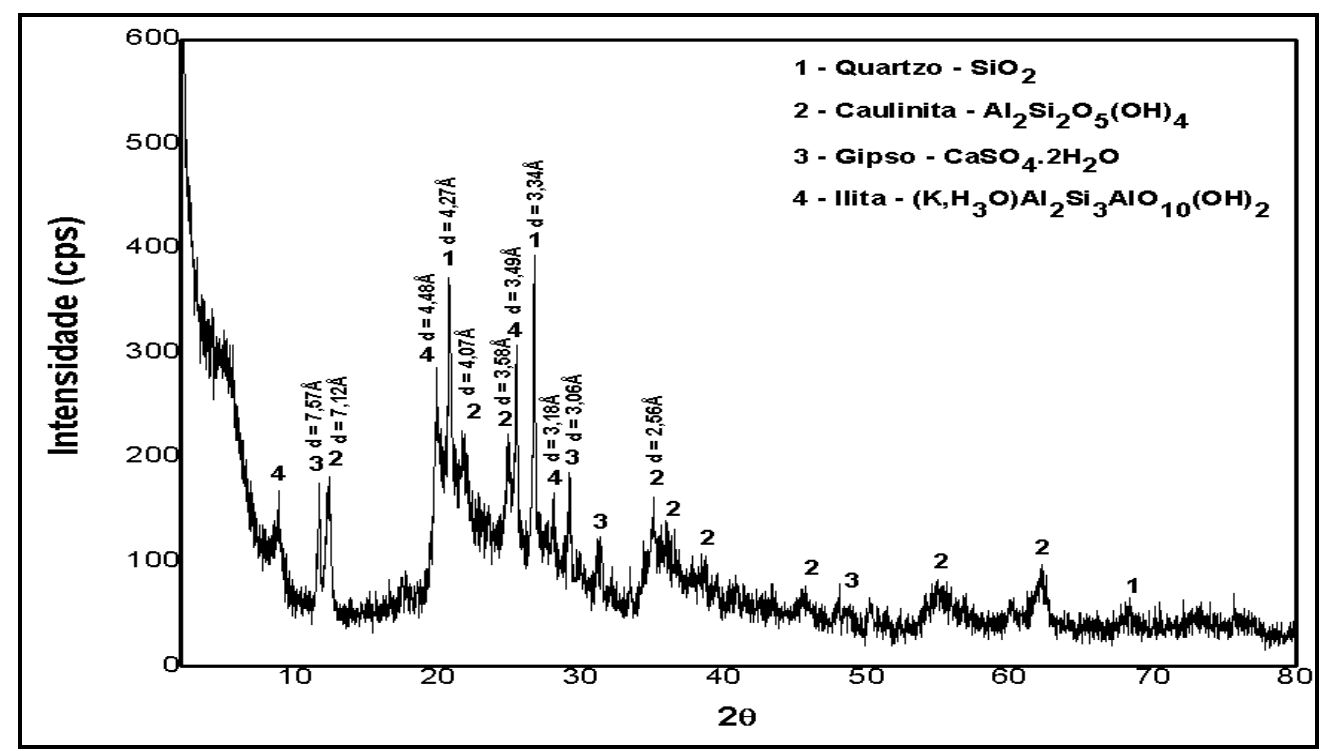

Figura 72: Curva de raios $X$ para argila $A 24$.

Analisando a curva de raios $X$ da figura 72 , foi possível verificar a presença de quatro fases na estrutura da amostra A24: a primeira fase é o quartzo, cuja fórmula é $\mathrm{SiO}_{2}$, a segunda fase é referente a fase caulinita de fórmula $\mathrm{Al}_{2} \mathrm{Si}_{2} \mathrm{O}_{5}(\mathrm{OH})_{4}$, a terceira fase refere-se a gipsita de fórmula $\mathrm{CaSO}_{4} \cdot 2 \mathrm{H}_{2} \mathrm{O}$, e por fim a fase ilita composta de 
$\mathrm{KAl}_{2}\left(\mathrm{Si}_{3} \mathrm{Al}\right) \mathrm{O}_{10}(\mathrm{OH})_{2}$. A ausência da reflexão do grupo da esmectíta $(\mathrm{E})$, provavelmente deve-se ao tratamento com ácido na argila ter sido bastante severo e ter destruído parcialmente a estrutura (RODRIGUES et.al., 2006) que corresponde ao argilomineral montmorilonítico. Porém, pode-se visualizar no difratograma um pico abaulado que antecede o primeiro pico da llita, o qual refere-se provavelmente a presença do argilomineral montmoriloníticos. Essa indicação poderá ser confirmada através da análise de FRX para a amostra A24.

Quanto a distâncias interplanares basais características do argilomineral, observou-se as seguintes: para o mineral acessório quartzo (Q) 4,27Á - 3,34Á,

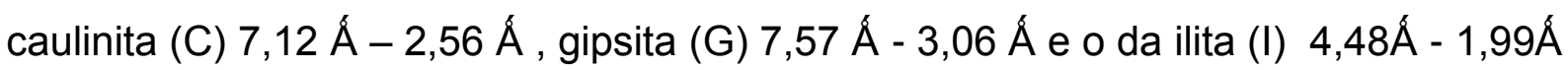
as mesmas encontram-se de acordo com a literatura (SOUZA SANTOS, 1992).

Fazendo uma análise conjunta dos espectros de difração de raios $X$, foi possível verificar que as argilas A23 e a argila A24 apresentaram fases cristalinas diferentes, porém, pode-se confirmar que provavelmente essas argilas tratam-se de amostras de bentonitas compostas predominantemente por argilominerais do grupo das esmectitas (montmorilonita) e que as mesmas apresentaram em sua composição o quartzo como mineral acessório.

Outra análise que pode ser feita através das curvas de raios $X$, é que a amostra A23 apresentou uma maior cristalinidade, quando comparada com a amostra A24. Esse comportamento foi observado pela intensidade dos picos ilustrados nos difratogramas, sugerindo portanto que o material A23 por ser mais cristalino, provavelmente apresentou uma maior área superficial e portanto, uma maior quantidade de sítios ativos [KANNAN et. al.,2005]. Essa afirmação poderá ser confirmada com a realização da análise textural de BET.

\subsection{FLUORESCÊNCIA DE RAIOS X}

O estudo da composição química das argilas A23 e A24 é importante para se determinar as características tecnológicas das argilas. $\mathrm{A}$ análise química semiquantitativa por fluorescência de raios $X$ (FRX) com perda ao rubro (PR), foi realizada a fim de investigar a composição química dos constituintes das argilas A23 e A 24, sendo mostrada na tabela 27. 
Tabela 27: Composição química das argilas A 23 e A24.

\begin{tabular}{|c|c|c|}
\hline & A23 & A24 \\
\hline Oxidos & (\%) & (\%) \\
\hline $\mathrm{SiO}_{2}$ & 71,81 & 57,01 \\
\hline $\mathrm{Al}_{2} \mathrm{O}_{3}$ & 14,99 & 14,01 \\
\hline $\mathrm{Fe}_{2} \mathrm{O}_{3}$ & 3,39 & 6,71 \\
\hline $\mathrm{K}_{2} \mathrm{O}$ & 2,65 & 2,43 \\
\hline $\mathrm{MgO}$ & 1,18 & 0,87 \\
\hline $\mathrm{TiO}_{2}$ & 0,64 & 1,58 \\
\hline $\mathrm{CaO}$ & 0,28 & 3,34 \\
\hline $\mathrm{SO}_{3}$ & 0,06 & 3,27 \\
\hline $\mathrm{ZrO}_{2}$ & 0,05 & 0,03 \\
\hline MnO & 0,04 & 0,11 \\
\hline CuO & 0,03 & 0,04 \\
\hline $\mathrm{ZnO}$ & 0,01 & 0,02 \\
\hline $\mathbf{P}_{2} \mathbf{O}_{5}$ & - & 0,1 \\
\hline SrO & - & 0,03 \\
\hline $\mathrm{Nb}_{2} \mathrm{O}_{5}$ & - & 0,02 \\
\hline $\mathrm{Y}_{2} \mathrm{O}_{3}$ & - & 0,02 \\
\hline P.R. & 4,87 & 10,41 \\
\hline
\end{tabular}

Através da análise de fluorescência de raios $X$ foi possível verificar que ambas as amostras dos catalisadores apresentaram em grande quantidade de $\mathrm{SiO}_{2}$ e $\mathrm{Al}_{2} \mathrm{O}_{3}$ perfazendo assim mais de $70 \%$ de cada amostra, sendo provavelmente provenientes dos argilominerais e da sílica livre presente nas amostras. Valores esses coerentes com a literatura (SOUZA SANTOS, 1992) e pequenas quantidades dos demais outros óxidos (inferiores a $3 \%$ ), não devendo alterar significativamente as propriedades tecnológicas dessas argilas. Ressalta-se que as argilas A23 e A24 possuem em sua composição a presença de $\mathrm{Mg}$, sendo a argila A24 em menor teor do que a argila A23. A presença de magnésio provavelmente indica que essa 
amostra trata-se de uma argila montomorilonítica, além disso, Kannan et. al., 2005 mostrou em seus trabalhos que quanto maior o teor de magnésio em determinados materiais, melhor será o ordenamento cristalino. Resultando portanto em materiais com maior área superficial, o que vem corroborar com os resultados de DRX anteriormente discutidos, ou seja, a amostra A23 por possuir maior teor de magnésio, possui maior cristalinidade e consequentemente apresentará maior área superficial e possivelmente melhor eficiência quando utilizada como catalisador no processo de produção de biodiesel.

A perda ao rubro representa a perda de água intercalada, perda de água de hidroxilas dos argilominerais, matéria orgânica e carbonatos (SOUZA SANTOS, 1992).Para as amostras estudadas, foi observado que os teores de PF variaram de 4,87 \% para a amostra A23 e 10,41\% para a amostra A24. Essa diferença deve-se ao fato de que possivelmente a amostra A24 apresentou em sua composição um maior teor de compostos voláteis (hidroxilas, matéria orgânica, etc.).

Portanto, os resultados mostrados na tabela 27 , evidenciaram que as amostras A23 e A24 apresentaram uma composição química típica de bentonitas tratadas com ácido, o que está de acordo com estudos realizados por Souza Santos (1992).

\subsection{ESPECTROSCOPIA NA REGIÃO DO INFRAVERMELHO}

Nas figuras 73 e 74 são mostrados os espectros vibracionais na região do infravermelho para as argilas A23 e A24.Todas as análises foram feitas em pastilhas de $\mathrm{KBr}$.

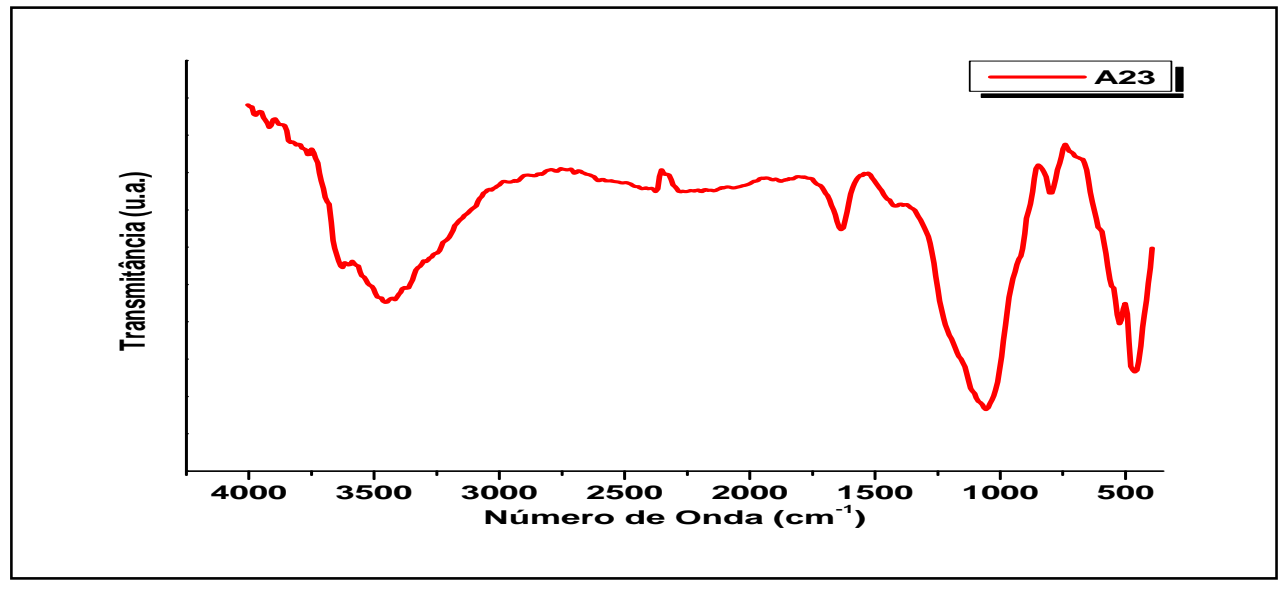

Figura 73 : Espectro de infravermelho da argila A23. 


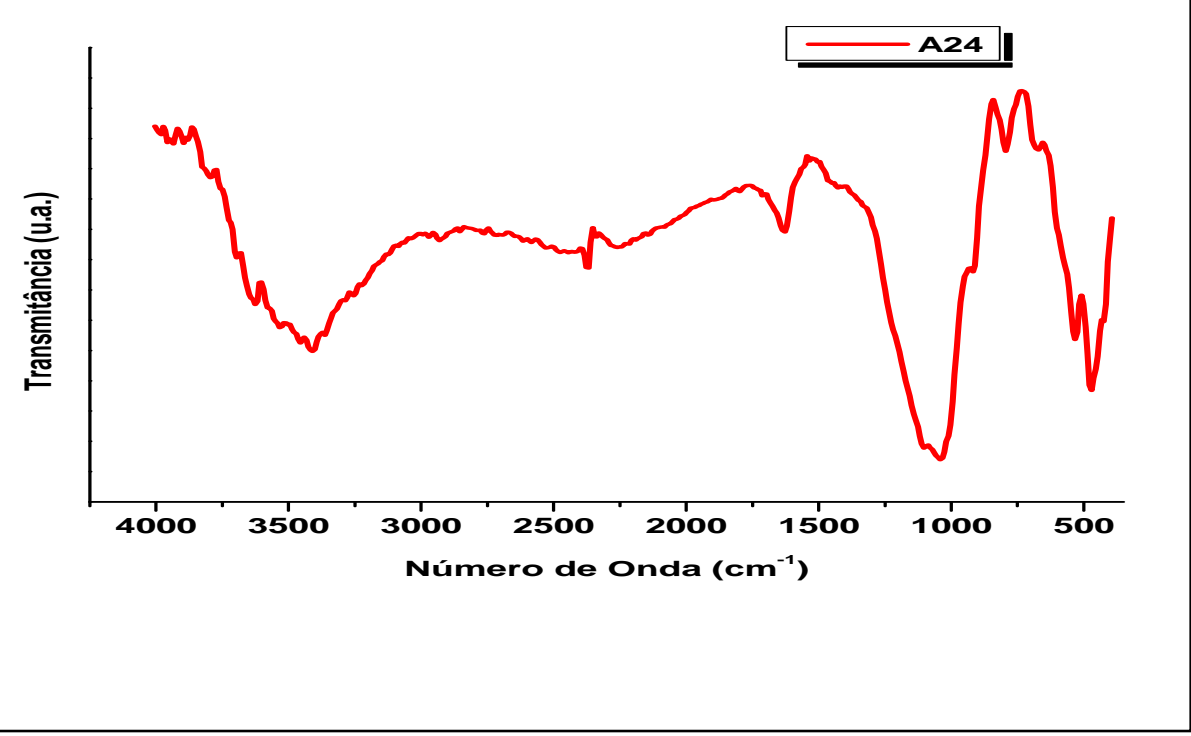

Figura 74: Espectro de infravermelho da argila A24.

Para os catalisadores a base de argilas A23 e A24 foi possível observar que os espectros de infravermelho possuem perfil de curvas parecidas, diferindo apenas em pequenos valores de número de onda e de intensidade de transmitância.

Através desses espectros foi possível identificar em $3626-3450 \mathrm{~cm}^{-1}$ a presença do estiramento do grupo hidroxila e do $\mathrm{OH}^{-}$referente a água adsorvida presente na bentonita. Como também a presença da vibração das ligações (Si-O) em $1040 \mathrm{~cm}^{-1}$, (Si-O-Al) em $520 \mathrm{~cm}^{-1}$,(Mg-Al-OH) em $800 \mathrm{~cm}^{-1}$ e $470 \mathrm{~cm}^{-1}$ novamente para a ligação (Si-O).

A amostra A23 apresentou um espectro praticamente dentro da mesma faixa de comprimento de onda apresentado pela amostra A24. Comparando-se as amostras A23 e A24, não foi percebida praticamente nenhuma alteração nas posições das bandas características das mesmas, já que tratam-se de amostras de bentonitas ácidas tecnicamente, esses espectros podem ser considerados iguais.

\subsection{MICROSCOPIA ELETRÔNICA DE VARREDURA}

Foram realizadas análises das imagens de microscopia eletrônica de varredura nas amostras dos catalisadores argilosos A23 e A24. As morfologias desses catalisadores podem ser vistas através das figuras 75 e 76, conforme um aumento de $1000 \mathrm{X}$. 
As micrografias eletrônicas de varredura para as amostras dos catalisadores A23 e A24, estão apresentadas nas figuras 75 e 76.

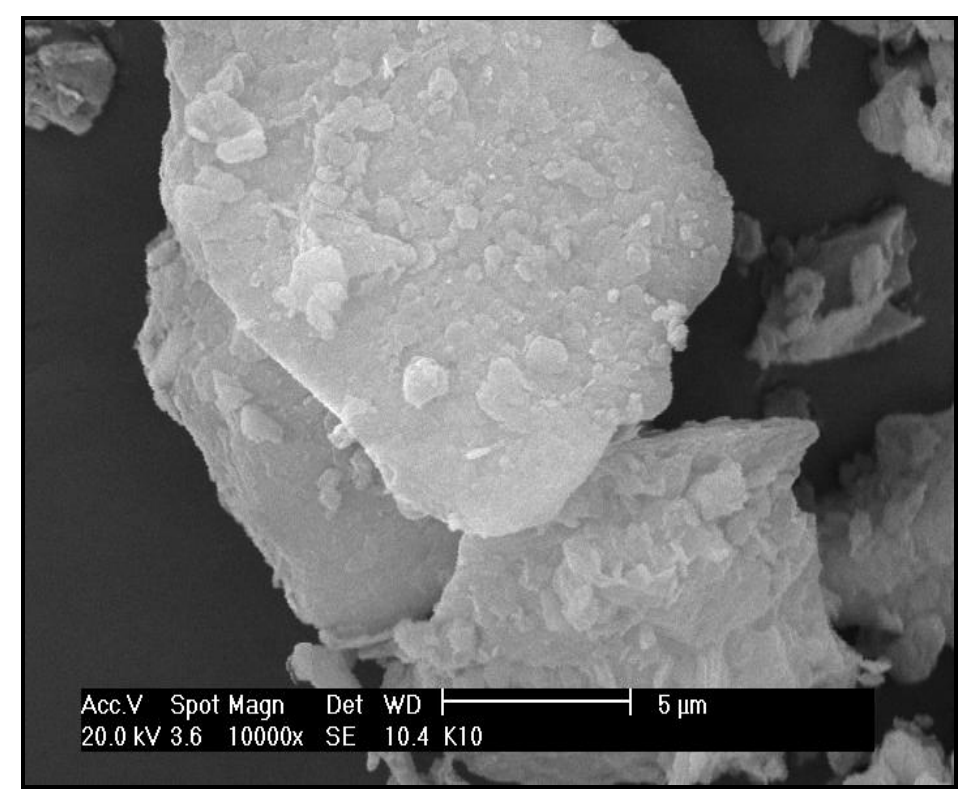

Figura 75: Micrografia obtida por MEV da argila A 23 com um aumento 1000X (a barra corresponde a $5 \mu \mathrm{m})$.

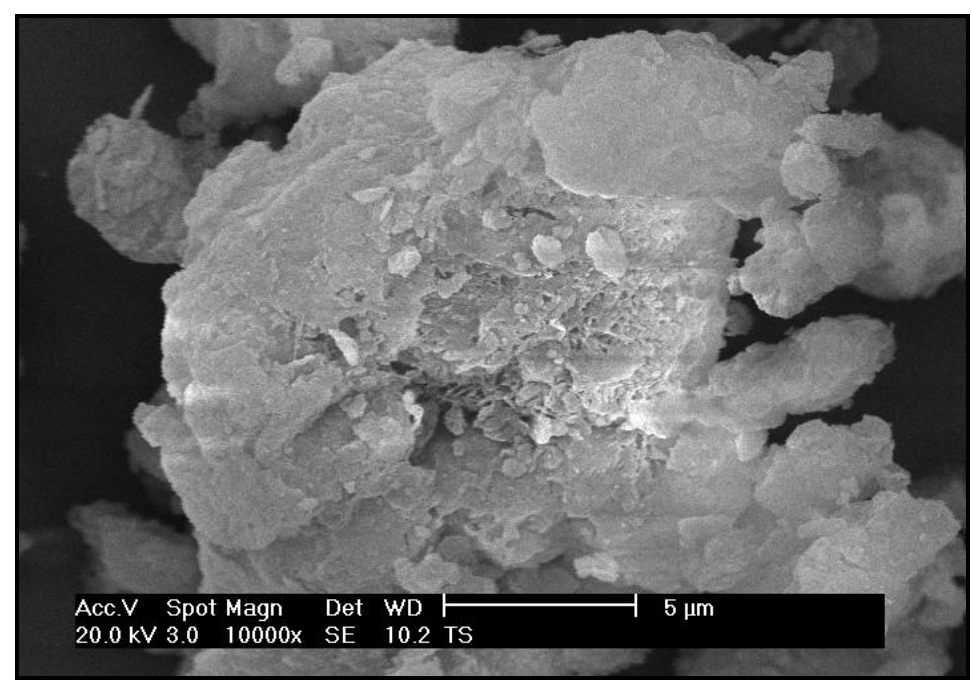

Figura 76: Micrografia obtida por MEV da argila A24 com um aumento 1000X (a barra corresponde a $5 \mu \mathrm{m})$. 
De forma geral, a partir de observações diretas das microscopias eletrônicas de varredura (figuras 75 e 76), foi possível verificar que todas as amostras dos catalisadores, por serem argilas esmectíticas ácidas, apresentaram morfologias similares. Portanto, verificou-se que não há uma distribuição muito homogênea de partículas, pois apresentaram grãos de diversos tamanhos, variando de 0,5 - 30,5 $\mu \mathrm{m}$ ocasionando, uma distribuição de partículas irregular. Observou-se ainda que essas amostras são constituídas por aglomerados de perfil irregular, notando-se empacotamentos de cristalitos maiores de $5 \mu \mathrm{m}$ e foi possível perceber a abundância de lamelas muito menores de $1 \mu \mathrm{m}$. Isto confirma a principal característica das bentonitas de apresentar menor tamanho dos seus componentes físicos dentre os minerais, por isso, a literatura relata uma grande contribuição das bentonitas para diferentes aplicações industriais (SOUZA SANTOS, 1975).

Verificou-se ainda que a morfologia lamelar das camadas que formaram as partículas elementares, assim como os tactóides (SILVA, 2005), foram formados pelo empilhamento dessas partículas lamelares. Notou-se, também os tactóides ligados entre si, formando aglomerados de diversas dimensões.

\subsection{ESPECTROSCOPIA DE RAIOS X POR ENERGIA DISPERSIVA}

No mesmo microscópio onde foram realizadas as microscopias eletrônicas de varredura para os catalisadores A23 e A24, foram também realizadas análises para a identificação dos elementos químicos presentes através do acessório de EDS anexado ao equipamento.

Nas figuras 77 e 78, são apresentados os resultados obtidos através da técnica de espectroscopia de raios $\mathrm{X}$ por energia dispersiva para os catalisadores à base de argilas A23 e A24. 


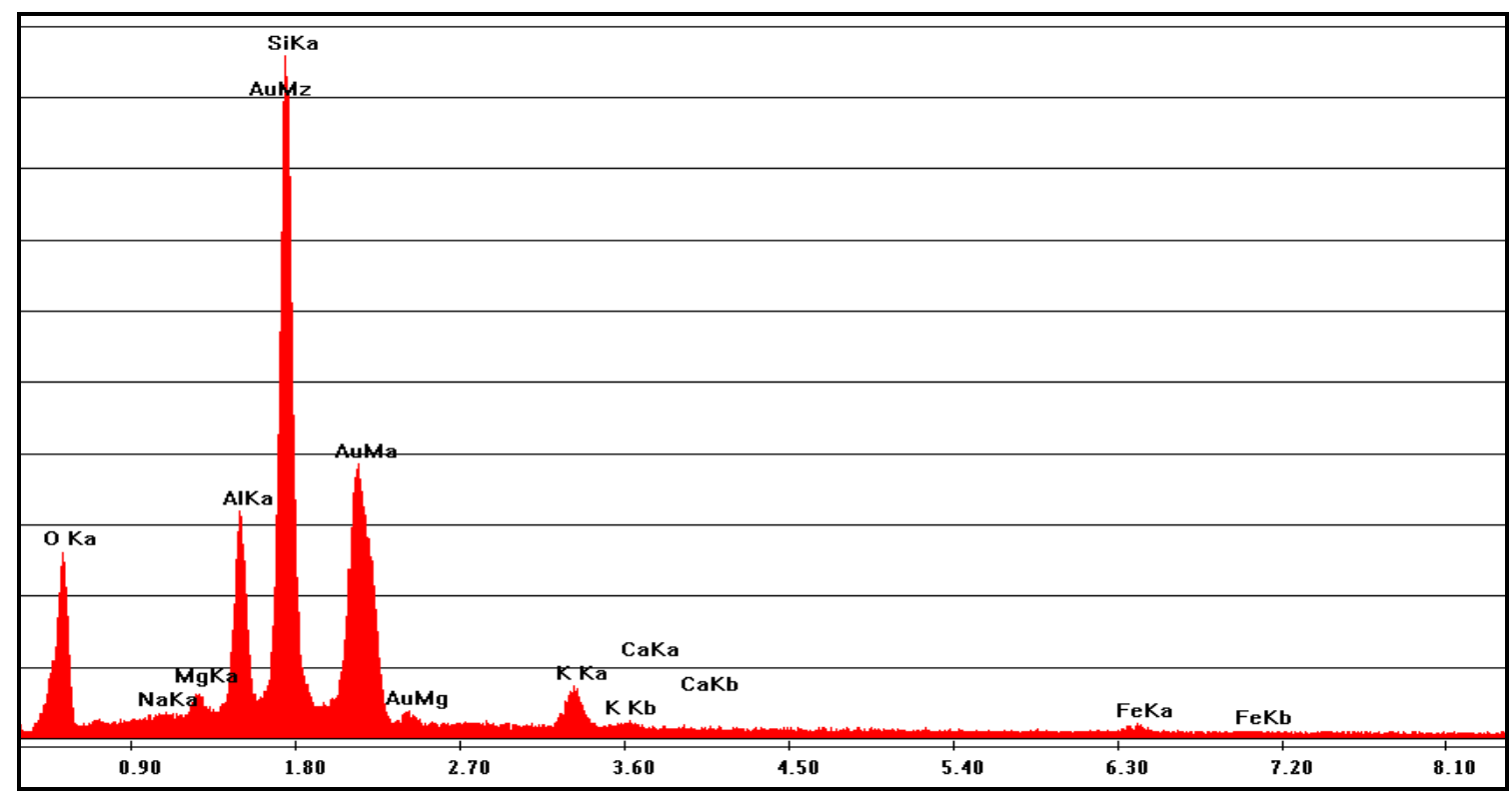

Figura 77: Espectroscopia de raios X por energia dispersiva da argila A23.

Para identificação dos elementos químicos, foi realizado através da técnica de EDS um ensaio pontual efetuado no catalisador A23. Verificou-se picos mais acentuados característicos basicamente de $\mathrm{Si}$ e Al, o qual evidenciou ser característico de bentonitas, bem como, traços de $\mathrm{Fe}, \mathrm{K}, \mathrm{Mg}$ e $\mathrm{Ca}$, identificados por picos de baixa intensidade. Esses resultados estão de acordo com a literatura Silva, 2005.

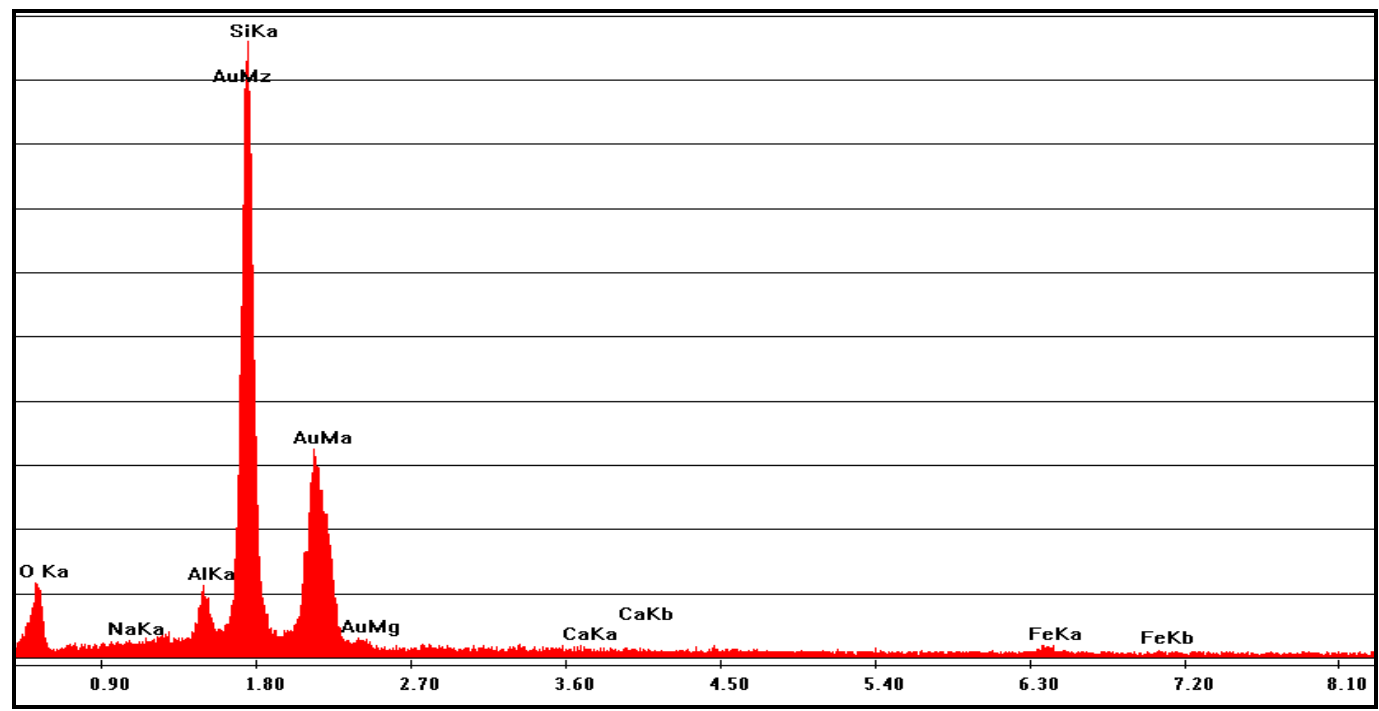

Figura 78: Espectroscopia de raios X por energia dispersiva da argila A24. 
Analisando a figura 78, observou-se a presença dos principais componentes das argilas esmectíticas, confirmando os resultados da fluorescência de raios $X$. Percebeu-se picos mais destacados de Si, Al, Mg e Fe. O Na marca presença num pico de baixa intensidade, porém maior que o de Ca que também é detectado no ponto analisado da amostra.

Logo, através dos resultados de EDS, foi possível verificar que 0 comportamento dos catalisadores A23 e A24 repetiram-se, devido ao fato de ambos tratarem-se de bentonitas ácidas, embora o catalisador A24 apresentou-se com menor intensidade para o caso dos elementos $\mathrm{Na}$ e $\mathrm{Ca}$.

A presença de picos de Au e $\mathrm{O}$ não estão relacionados com a natureza das argilas, deve-se simplesmente, ao processo de metalização a vácuo, necessário para poder efetuar a microscopia eletrônica de varredura.

\subsection{CARACTERIZAÇÃO TEXTURAL (BET)}

A acessibilidade da superfície catalítica aos reagentes gasosos é de importância considerável na seleção dos materiais sólidos que tem que funcionar como catalisadores para reações heterogêneas. A medida da área da superfície é extremamente importante na predição do desempenho do catalisador na reação heterogênea gasosa. A textura das argilas A23 e A24 foram estudadas através da medida da área específica. Os resultados obtidos nessa caracterização textural estão mostrados na tabela 28 .

Tabela 28: Características texturais dos catalisadores argilosos.

\begin{tabular}{cc} 
CATALISADOR & ÁREA ESPECÍFICA $\left(\mathbf{m}^{2} / \mathbf{g}\right)$ \\
\hline A23 & 237.705 \\
A24 & 169.342 \\
\hline
\end{tabular}


Observando os resultados para a análise de BET expostas na tabela 28 foi possível verificar que o catalisador A23 apresentou uma área superficial, na faixa de $237.705\left(\mathrm{~m}^{2} / \mathrm{g}\right)$, enquanto o catalisador A24 a faixa de $169.342\left(\mathrm{~m}^{2} / \mathrm{g}\right)$. Fazendo uma análise dos resultados foi possível observar que o catalisador A23 apresentou uma maior área superficial, logo, pode-se afirmar que provavelmente o mesmo apresentará uma melhor atividade catalítica no processo de produção do biodiesel por possuir um maior número de sítios ativos, que o catalisador A24, devido ao fato que para catalisadores heterogêneos, quanto maior a área disponível para adsorção, mais eficiente será o catalisador no processo (RODRIGUES et. al.,2006) .

Essa análise textural vem corroborar com os resultados encontrados na análise de DRX e FRX, sugerindo que provavelmente o catalisador A23 apresentará um melhor comportamento catalítico, devido às modificações ácidas sofridas em sua estrutura terem proporcionado uma alta área específica, consequentemente um aumento da atividade catalítica e adsorvente desse mineral argiloso.

\subsubsection{PARTE 4: CARACTERIZAÇÃO DO ÓLEO DE SOJA E DOS BIODIESEIS PRODUZIDOS ATRAVÉS DO SISTEMA S3}

\subsection{CARACTERIZAÇÃO DO ÓLEO DE SOJA}

Foram realizadas as seguintes caracterizações no óleo da soja: composição química, umidade, acidez, densidade $20^{\circ} \mathrm{C}$, glicerol total e viscosidade $40^{\circ} \mathrm{C}$ que serão detalhadas a seguir.

\subsection{COMPOSIÇÃO QUÍMICA DO ÓLEO DE SOJA}

Na tabela 29, encontra-se descrita a composição química do óleo de soja comercial utilizado nessa pesquisa.

Tabela 29: Composição de ácidos graxos do óleo de soja utilizado.

\begin{tabular}{cc} 
ACIDOS GRAXOS & CONCENTRAÇAOO (\%) \\
\hline Palmitato & 12,36 \\
Estearato & 4,61 \\
\hline
\end{tabular}




\begin{tabular}{|cc}
\hline Oléico & 26,82 \\
\hline Linoléico & 51,2 \\
\hline Linolênico & 5,01 \\
\hline
\end{tabular}

Fazendo uma análise dos resultados da tabela 29 observou-se que a composição química dos ésteres encontrou-se na mesma faixa reportada por Rossi (2000), tratando-se, portanto de um óleo de soja comercial, tendo em vista que, os óleos vegetais são produtos naturais constituídos por uma mistura de ésteres derivados do glicerol (triacilgliceróis ou triglicerídios), cujos ácidos graxos contêm cadeias variando de 8 a 24 átomos de carbono com diferentes graus de insaturação.

Conforme exposto na tabela 29, verificou-se ainda que o óleo de soja utilizado nessa pesquisa tratava-se de uma mistura principal dos óleos: Palmitato, Estearato, Oléico, Linoléico e Linolênico, confirmando as concentrações descritas pela literatura.

\subsection{CARACTERÍSTICAS FÍSICO-QUÍMICAS DO ÓLEO DE SOJA}

O óleo de soja utilizado para a obtenção do biodiesel foi submetido às diversas análises, dentre elas pode-se ressaltar o de índice de acidez e teor de umidade, pois são variáveis importantes no processo de produção do biodiesel.

A tabela 30 apresenta os dados comparativos para índice de acidez, teor de umidade, viscosidade cinemática, glicerol total e densidade para o óleo de soja utilizado para nessa pesquisa.

Tabela 30: Características físico-químicas do óleo de soja.

\begin{tabular}{cc|}
\hline ANÁLISES & OLEO DE SOJA ESTUDADO \\
\hline UMIDADE A $85^{\circ} \mathrm{C}(\%)$ & 0,0137 \\
\hline ÍNDICE DE ACIDEZ(mg de $\mathrm{NaOH} / \mathrm{g})$ & 0,2748 \\
\hline GLICEROL TOTAL(\%) & 4,89 \\
\hline DENSIDADE $\mathbf{2 0}^{\circ} \mathrm{C}\left(\mathbf{g} / \mathrm{cm}^{3}\right)$ & 0,9202 \\
\hline VISCOSIDADE $\mathbf{4 0}{ }^{\circ} \mathrm{C}\left(\mathrm{mm}^{2} / \mathbf{s}\right)$ & 32,8097 \\
\hline
\end{tabular}


De acordo com os resultados apresentados na tabela 30 , verificou-se que 0 teor de umidade foi 0,0137 \% e o índice de acidez de 0,2748 $\mathrm{mg}$ de $\mathrm{NaOH} / \mathrm{g}$, estando portanto dentro das especificações reportadas por Fagundes (2006) e Freedmanet. al., (1984) que afirmaram que os óleos que apresentam valores superiores a 0,8 de acidez e 0,3 de umidade promovem a reação de saponificação, transformando os ácidos graxos livres em sabão e formando moléculas de água, afetando diretamente o rendimento

Logo, esses valores de índice de acidez e teor de umidade indicam que durante a reação de transesterificação para produção do biodiesel de soja, provavelmente não ocorrerão reações paralelas como a reação de saponificação, nem o rendimento da mesma será afetado diretamente.

As demais análises foram realizadas apenas como parâmetro comparativo com os valores encontrados para o biodiesel formado a partir das 16 composições. Logo, os valores apresentados pela tabela 30 para essas análises foram: glicerol total do óleo de soja de 4,89\%, densidade $0,9202 \mathrm{~g} / \mathrm{cm}^{3}$ e viscosidade do óleo de soja foi de $32,8097 \mathrm{~mm}^{2} / \mathrm{s}$.

\subsection{CARACTERIZAÇÃO DO BIODIESEL ETÍLICO E METÍLICO}

Para caracterização do biodiesel obtido, utilizou-se as seguintes técnicas: composição química, umidade, acidez, viscosidade cinemática, teor de éster, teor de álcool e cromatografia gasosa.

\subsection{COMPOSIÇÃO QUÍMICA DO BIODIESEL}

Na tabela 31 abaixo encontram-se descritos os ácidos graxos para as 16 composições estudadas no desenvolvimento desta pesquisa.

Tabela 31: Composição de ácidos graxos do biodiesel de óleo de soja, via rota etílica e metílica.

\begin{tabular}{|cccccc|c|}
\hline $\begin{array}{c}\text { ACIDOS } \\
\text { GRAXOS }\end{array}$ & Palmitato & Estearato & Oléico & Linoléico & Linolênico & Palmitênico \\
\hline C1(\%) & 17,17 & 4,61 & 31,63 & 43,89 & 2,68 & - \\
\hline
\end{tabular}




\begin{tabular}{lccccccc}
\hline C2(\%) & 25,33 & 28,70 & 22,63 & 23,32 & - & - \\
\hline C3(\%) & 19,66 & 4,76 & 36,17 & 37,21 & 2,17 & - \\
\hline C4(\%) & 22,06 & 9,61 & 31,36 & 16,32 & 20,64 & - \\
\hline C5(\%) & 18,85 & 4,04 & 38,15 & 37,03 & 1,91 & - \\
\hline C6(\%) & $\mathrm{Nd}$ & $\mathrm{Nd}$ & $\mathrm{Nd}$ & $\mathrm{Nd}$ & $\mathrm{Nd}$ & - \\
\hline C7(\%) & 26,80 & 9,82 & 26,83 & 21,69 & 14,84 & - \\
\hline C8(\%) & 28,01 & 5,91 & 50,77 & 12,83 & 2,46 & - \\
C9(\%) & 16,47 & 3,26 & 23,26 & 51,53 & 5,46 & - \\
\hline C10 (\%) & 17,59 & 7,71 & 22,74 & 15,39 & 23,44 & 13,11 \\
\hline C11 (\%) & $\mathrm{Nd}$ & $\mathrm{Nd}$ & $\mathrm{Nd}$ & $\mathrm{Nd}$ & $\mathrm{Nd}$ & $\mathrm{Nd}$ \\
\hline C12 (\%) & 21,28 & 7,61 & 33,60 & 6,68 & 20,85 & 9,95 \\
\hline C13 (\%) & 2,20 & 0,74 & 1,87 & 30,62 & 48,88 & 15,67 \\
\hline C14 (\%) & 23,57 & 9,81 & 27,20 & 10,37 & 18,16 & 10,86 \\
\hline C15 (\%) & $\mathrm{Nd}$ & $\mathrm{Nd}$ & $\mathrm{Nd}$ & $\mathrm{Nd}$ & $\mathrm{Nd}$ & $\mathrm{Nd}$ \\
\hline C16 (\%) & $\mathrm{Nd}$ & $\mathrm{Nd}$ & $\mathrm{Nd}$ & $\mathrm{Nd}$ & $\mathrm{Nd}$ & $\mathrm{Nd}$ \\
\hline $\mathrm{Nd}$
\end{tabular}

$\mathrm{Nd}=$ não determinado.

Fazendo uma análise dos resultados da tabela 31 observou-se que a composição química das amostras referentes aos ésteres etílicos (C1, C2, C5, C6, C9, C10, C13, C14) encontravam-se na mesma faixa reportada por Ferrari, Oliveira e Scabio (2005), não havendo muitas discrepâncias desses valores, por tratarem-se de ácidos graxos do biodiesel de óleo de soja produzidos via rota etílica.

Outro fator importante reportado por Rossi (2005), que pode ser verificado pelos resultados apresentados através da tabela 31 é que para estes ácidos graxos, a proporção relativa é mantida constante após a reação de transesterificação, compondo mais de 95 \% do teor de ácidos graxos do óleo.

Conforme exposto na tabela 31, nas 16 composições verificou-se a presença de uma mistura principal dos ácidos graxos: Palmitato, Estearato, Oléico, Linoléico e Linolênico, confirmando as concentrações descritas pela literatura (FERRARI, OLIVEIRA e SCABIO 2005) para o biodiesel etílico e Palmitato, Estearato, Oléico, Linoléico, Linolênico e Palmitoléico para o biodiesel metílico, também confirmando o que foi descrito por Candeia (2008).

Analisando o comportamento das 16 composições foi possível constatar que não se percebe diferenças significativas nas composições preparadas com o mesmo catalisador, seja biodiesel via rota metílica ou etílica, no que diz respeito aos teores de ácidos graxos. Porém, a diferença de composição entre os biodieseis preparados 
com catalisadores A23 e A24 foi percebida pela presença do ácido graxo palmitoleíco evidenciado nas amostras preparadas com o catalisador A24.

Comparando esses resultados com o resultado para o óleo puro, percebe-se que há uma redução para todas as 16 composições dos ácidos graxos insaturados e um acréscimo dos ácidos graxos saturados. Esse comportamento pode ser explicado levando-se em consideração que quando ocorre reação de transesterificação, ocorre a quebra das insaturações dos triacilgliceróis, ocasionando uma redução dos ácidos graxos insaturados que transformam-se em ácidos graxos saturados. Todo esse processo ocasiona uma redução dessa viscosidade do óleo, indicando a eficácia do processo de transesterificação (CANDEIA, 2008).

Outro fator que pode ser observado foi que à proporção que se eleva a temperatura da reação transesterificação, os resultados da concentração de ácidos graxos no biodiesel formado foram alterados. Os ácidos graxos saturados (Palmitato, Estearato) sofreram uma redução e os ácidos graxos insaturados (Oléico, Linoléico e Linolênico) sofreram um aumento. Esse comportamento foi observado tanto para o biodiesel produzido via rota etílica, quanto para as amostras de biodiesel produzidas via rota metílica. Esse fato confirmou o que foi descrito pela literatura (FERRARI, OLIVEIRA e SCABIO, 2005) quando relatava que a elevação da temperatura altera os teores de ésteres, por isso é importante que se determine a temperatura ideal para o processo de transesterificação evitando decomposição do óleo.

\subsection{CARACTERÍSTICAS FISICO-QUÍMICAS DO BIODIESEL}

Com a finalidade de comprovar a eficiência da utilização de catalisadores argilosos para produção do biodiesel, foram realizadas as caracterizações físicoquímica do biodiesel obtido, utilizando-se as seguintes técnicas: composição química, umidade, índice de acidez, viscosidade cinemática, teor de éster, teor de álcool e cromatografia gasosa.

As caracterizações do biodiesel obtido encontram-se na tabela 32, onde os parâmetros estabelecidos estão de acordo com a resolução № 7 da Agência Nacional do Petróleo, Gás Natural e Biocombustíveis (ANP) de 19.3.2008- DOU 20.3.2008.o é um fator que condiciona um bom funcionamento e tempo de vida útil de um motor. Independente da rota tecnológica de produção, a aceitação do 
biodiesel no mercado precisa ser assegurada e, para isso, é imprescindível que esse produto esteja dentro das especificações internacionalmente aceitas para o seu uso. 
Tabela 32: Caracterização físico-química do biodiesel etílico e metílico.

\begin{tabular}{|c|c|c|c|c|c|c|c|c|c|c|c|c|c|c|c|c|c|c|}
\hline TEMPERATURA & ${ }^{\circ} \mathrm{C}$ & 200 & 100 & 200 & 100 & 200 & 100 & 200 & 100 & 200 & 100 & 200 & 100 & 200 & 100 & 200 & 100 & \\
\hline $\begin{array}{l}\text { TEMPO DE } \\
\text { REAÇÃO }\end{array}$ & Min & 30 & 30 & 30 & 30 & 60 & 60 & 60 & 60 & 30 & 30 & 30 & 30 & 60 & 60 & 60 & 60 & \\
\hline ANÁLISES & UNIDADES & $\mathrm{C}_{1}$ & $\mathrm{C}_{2}$ & $\mathrm{C}_{3}$ & $\mathrm{C}_{4}$ & $\mathrm{C}_{5}$ & $\mathrm{C}_{6}$ & $\mathrm{C}_{7}$ & $\mathrm{C}_{8}$ & $\mathrm{C}_{9}$ & $\mathrm{C}_{10}$ & $\mathrm{C}_{11}$ & $\mathrm{C}_{12}$ & $\mathrm{C}_{13}$ & $\mathrm{C}_{14}$ & $\mathrm{C}_{15}$ & $\mathrm{C}_{16}$ & $\begin{array}{c}\text { ESPECIFICAÇÕES } \\
\text { ANP }\end{array}$ \\
\hline Umidade a $85^{\circ} \mathrm{C}$ máx & (\%)massa & 0,02 & 0,021 & 0,03 & 0,028 & 0,023 & 0,010 & 0,022 & 0,013 & 0,018 & 0,024 & 0,027 & 0,030 & 0,030 & 0,023 & 0,026 & 0,024 & 0,05 \\
\hline Índice de acidezmáx & (mg de $\mathrm{NaOH} / \mathrm{g}$ ) & 0,3 & 0,3 & 0,3 & 0,3 & 0,3 & 0,3 & 0,3 & 0,3 & 0,4 & 0,4 & 0,4 & 0,4 & 0,4 & 0,4 & 0,4 & 0,4 & 0,50 \\
\hline Glicerol livre, máx. & (\%) massa & 0,0052 & 0,0003 & 0,002 & 0,0001 & 0 & 0,0063 & 0,0029 & 0,0165 & 0,0021 & 0,0004 & 0,0003 & 0,0002 & 0,0087 & 0,0001 & 0,0003 & 0,0002 & 0,02 \\
\hline Glicerol total, máx. & (\%) massa & 0,0019 & 0,00046 & 0,001 & 0,0004 & 0 & 0,003 & 0,00093 & 0,00776 & 0,00129 & 0,0005 & 0,00055 & 0,00047 & 0,0041 & 0,0004 & 0,00039 & 0,00048 & 0,25 \\
\hline $\begin{array}{l}\text { Viscosidade } \\
\text { Cinemática } 40^{\circ} \mathrm{C}\end{array}$ & $\left(\mathrm{mm}^{2} / \mathrm{s}\right)$ massa & 25,09 & 31,71 & 21,83 & 31,55 & 20,63 & 31,43 & 28,91 & 31,91 & 27,57 & 31,78 & 28,20 & 31,97 & 25,96 & 31,98 & 28,04 & 31,45 & $3,0-6,0$ \\
\hline Teor de Èster min. & (\%) massa & 10,53 & 0,36 & 13,99 & 0,70 & 17,42 & 0,45 & 5,38 & 0,16 & 4,47 & 0,54 & 3,42 & 0,77 & 7,03 & 0,51 & 3,64 & 0,92 & 96,5 \\
\hline Teor de ÁlcoolMax. & $(\%)$ massa & 0,0054 & 0,0048 & 0 & 0,0003 & 0 & 0 & 0,0007 & 0 & 0,0003 & 0,0021 & 0,0021 & 0,0036 & 0,0141 & 0,0064 & 0,007 & 0 & 0,20 \\
\hline Monoglicerídeos & (\%) massa & 0,97 & 0,21 & 1,52 & 0,11 & 0,41 & 0,12 & 0,9 & 0,12 & 0,33 & 0,19 & 0,16 & 0,13 & 0,55 & 0,11 & 0,29 & 0,12 & Anotar \\
\hline Diglicerídeos & (\%) massa & 12,04 & 2,63 & 9,11 & 1,66 & 17,70 & 1,61 & 7,53 & 1,61 & 6,50 & 3,42 & 4,52 & 2,25 & 9,02 & 1,45 & 9,45 & 2,16 & Anotar \\
\hline Triacilglicerídeos & (\%) massa & 86,98 & 97,16 & 89,37 & 98,23 & 81,89 & 98,27 & 91,57 & 98,27 & 93,17 & 96,39 & 95,32 & 97,62 & 90,42 & 98,44 & 90,26 & 97,72 & Anotar \\
\hline
\end{tabular}


Neste sentido, as análises físicas e químicas dos biocombustíveis derivados do óleo de soja neste trabalho, foram comparadas com a resolução da ANP №7.

Observando a tabela 32, verificou-se que os resultados obtidos para os biodieseis produzidos pela rota etílica e metílica utilizando os catalisadores A23 e A24, corroboraram com os limites permitidos pela Agência Nacional de Petróleo, Gás Natural e Biocombustíveis (ANP).

No que diz respeito à análise de Umidade à $85^{\circ} \mathrm{C}$, verificou-se que todas as amostras encontraram-se de acordo com as especificações da ANP. As amostras variaram entre 0,01-0,03 \%. Entretanto, é importante ressaltar que mesmo controlando a umidade dentro dos limites estabelecidos, o biodiesel requer atenção, pois por ser higroscópico o mesmo possui afinidade com o vapor d'água. A literatura aponta que a presença de água em excesso no combustível pode provocar corrosão nos motores que o utilizam, além de favorecer o crescimento de microrganismos (CANDEIA, 2008).

Para a análise do Índice de Acidez foi possível observar que todos os valores encontraram-se de acordo com os limites permitidos pela ANP. Verifica-se uma variação de 0,4-0,3 mg de $\mathrm{NaOH} / \mathrm{g}$. O índice de acidez elevado pode catalisar reações intermoleculares dos triacilgliceróis, ao mesmo tempo em que afeta a estabilidade térmica do combustível na câmara de combustão. Além disso, para o caso do carburante de óleo, a elevada acidez livre tem ação corrosiva sobre os componentes metálicos do motor (LIMA, 2008).

Para os valores de Glicerol Livre e Glicerol Total verificou-se que os resultados obtidos para todas as amostras atenderam a legislação que estabelece uma tolerância máxima de $0,02 \%$ e 0,25 \%, respectivamente. Percebeu-se uma variação para o glicerol total de 0 - 0,003 \% e para o glicerol livre de 0 - 0,002 \%. Através desse resultado foi possível comprovar a eficiência do processo de purificação utilizado para esses biodieseis (CANDEIA, 2008).

Os valores para a Viscosidade Cinemática a $40^{\circ} \mathrm{C}$ para todos os biodieseis obtidos a partir dos catalisadores heterogêneos encontraram-se acima do limite permitido pela ANP. Este valor pode ser atribuído aos elevados teores de di e triacilglicerídeos, conforme verificado através da análise cromatográfica exposto na tabela 32. Porém, fazendo uma análise desse resultado, para as 16 composições de biodiesel, observou-se que antes do processo de transesterificação, a viscosidade absoluta do óleo de soja era de aproximadamente $32,80\left(\mathrm{~mm}^{2} / \mathrm{s}\right)$ devido ao tamanho 
da cadeia dos ácidos graxos. Depois da reação de transesterificação, com biodieseis nas rotas etílica e metílica evidenciou-se uma redução dessa viscosidade, que foi proveniente da quebra dos triacilgliceróis, tendo como resultados os ésteres metílicos e etílicos, indicando a eficácia do processo de transesterificação. Destaque para a amostra C5 que apresentou uma menor viscosidade e consequentemente uma maior conversão parcial do biodiesel. Esse resultado pode ser explicado levando-se em consideração que devido esse material ter sido submetido a temperaturas elevadas $\left(200^{\circ} \mathrm{C}\right)$, houve uma maior quebra das insaturações, ocasionando a diminuição da viscosidade. Esses resultados estão de acordo com os resultados encontrados por Candeia (2008).

Observando os resultados do Teor de Éster verifica-se que os valores encontram-se de acordo com a especificação da ANP. Variando entre 0,36-17,42 \%. Analisando esses resultados foi possível observar que dentre as composições estudadas utilizando o catalisador A23, percebeu-se que as composições que apresentaram uma melhor conversão foram a C5, C3, C1 e C7 apresentando conversões de 17,42 \%, 13,99 \%, 10,53 \% e 5,38 \% respectivamente. Já dentre 0 lote das composições utilizando o catalisador A24 foram a C13, C9, C15 e C11 apresentando conversões de 7,03 \%, 4,47 \%, 3,64 \% e 3,42 \%. Esses resultados demonstraram que:

1) Conforme descrito na literatura (GRABOSKI, 1998 apud SILVA, 2008) a temperatura é um fator que influencia na reação de transesterificação. Silva (2008) reporta em seus trabalhos que obteve as maiores conversões de seus catalisadores heterogêneos, quando utilizou temperaturas que variaram acima de $200^{\circ} \mathrm{C}$. O estudo realizado por Silva (2008) vem a corroborar com os resultados obtidos nessa tese. Pois através desta, foi possível verificar que dentre as 16 composições utilizando as amostras A23 e A24, as que obtiveram uma maior conversão foram aquelas que utilizaram $200^{\circ} \mathrm{C}$ no processo de transesterificação (Destaque para o lote A23 = C5, C3, C1 e C7/ Destaque para o lote $\mathrm{A} 24=\mathrm{C} 13, \mathrm{C}$, C15 e C11). Esse resultado pode ser explicado levando-se em consideração que a conversão do éster aumenta com o aumento da temperatura ([SILVA, 2008). Destacou-se 
então a amostra C5 como sendo o biodiesel que apresentou uma melhor conversão.

2) Outro fator que influencia na reação de transesterificação é o tempo de reação. Candeia (2008) descreveu em sua tese que altos rendimentos e conversões da reação transesterificação estavam diretamente interligados com o tempo reacional. A mesma descreveu que os ésteres de ácidos graxos etílicos levam 60 minutos para serem transesterificados completamente. Deste modo, os resultados encontrados estão coerentes com a literatura, pois novamente dentre as 16 composições utilizando as amostras A23 e A24, as que apresentaram maior conversão foram os submetidos a 60 minutos de reação, ou seja, C5, C3, C1, C7, C13, C9, C15 e C11. Esse efeito pode ser explicado pela excitação e relaxação dos elétrons, uma vez que está ocorrendo um mudança estrutural para a formação dos produtos. Logo, faz-se necessário um tempo determinado para que a reação ocorra completamente. Novamente destacou-se o material C5 como sendo o biodiesel que apresentou melhor conversão.

3) A razão molar álcool e triacilglicerídeo também são variáveis importantes e afetam o rendimento do éster, descreveu Silva (2008) em seus trabalhos. A literatura mostra que a relação estequiométrica para transesterificação geralmente requer a utilização de uma razão mínima de três mols de álcool e um mol de triacilglicerídeo e que a razão molar está diretamente associada com o tipo de catalisador. Nesse trabalho foi utilizado uma razão molar de 1,76:1 de etanol em relação ao óleo de soja e 8,1:1de metanol em relação ao óleo de soja. Freedman (1986) necessitou de uma relação de 30:1 de butanol em relação ao óleo de soja para uma reação catalisada por ácido, enquanto a mesma reação catalisada por base requereu somente uma relação de 6:1 para se conseguir o mesmo rendimento em éster para um dado tempo de reação. Silva (2008) mostrou que realizando reação de transesterificação para produção de biodiesel de óleo de soja, utilizando catalisador heterogêneo obteve-se maiores conversões quando utilizou razões molares de 13:1 álcool óleo de soja. Logo, 
comparado os resultados obtidos nessa tese para a composição que apresentou a melhor conversão, a amostra C5, percebeu-se que a conversão parcial de $17,42 \%$ é considerada alta para a razão molar de 1,76:1, quando comparada com os demais autores. Demonstrando com isso a eficiência da utilização de catalisadores a base de argilas para produção de biodiesel. Percebeu-se ainda, que para melhorar esses valores de conversão, existe a necessidade de otimizar os valores da razão molar utilizada para esse catalisador (A23), ficando a sugestão para trabalhos futuros na área.

4) Candeia (2008), descreveu em seu trabalho que existe uma diferença significativa na síntese do biodiesel quando se altera o tipo de álcool (biodiesel metílico e etílico), utilizado no processo de transesterificação. Os resultados obtidos nessa tese confirmaram a afirmação do autor. Percebeu-se que os catalisadores a base de argilas quando submetidos a reações de transesterificação, utilizando o etanol e o óleo de soja, a elevadas temperaturas (de $200^{\circ} \mathrm{C}$ ) apresentaram um melhor desempenho desses materiais quando comparadas com metanol e óleo de soja. A amostra A23 apresentou um desempenho de pelo menos 2 vezes maior do que o mesmo material submetido às mesmas condições porém utilizando metanol. Esse fato pode ser explicado levando-se em consideração que as composições preparadas com etanol apresentaram uma maior eficiência de separação de fases que contêm os ésteres (parte superior) e o glicerol (parte inferior), aumentando com isso o rendimento (CANDEIA, 2008).

5) O catalisador utilizado, segundo Silva (2008), também é um fator que influencia a reação de transesterificação. Silva (2008) ressaltou que catalisadores alcalinos são mais efetivos na reação de transesterificação, quando comparados ao catalisador ácido. A concentração em peso do catalisador poderá levar a um aumento da conversão, porém, deve ser levado em conta os custos extras relacionados com a remoção do mesmo no meio reacional. Observando o desempenho dos catalisadores utilizados nesse processo (A23 e A24) de produção do biodiesel com óleo de soja, via 
rota etílica e metílica, verificou-se que o catalisador A23 apresentou melhores valores de conversão, destaque para a composição C5. Esse comportamento pode ser explicado levando-se em consideração a diferença de estrutura apresentada pelos catalisadores A23 e A24, conforme discutida anteriormente. Logo, a melhor eficiência apresentada pelo catalisador A23 deve-se provavelmente ao mesmo apresentar fases diferenciadas que contemplam o aparecimento da fase montmorilonita (verificado através da análise de DRX), o qual em trabalhos realizados por Rodrigues et.al.(2006) comentou-se que os materiais argilosos que apresentam a montmorilonita como argilomineral em sua estrutura, apresentam propriedades catalíticas interessantes devido ao fato desses materiais após sofrerem modificações ácidas apresentarem alta área específica, alta porosidade, alta acidez e serem termicamente estáveis, já que o tratamento ácido da montmorilonita tem a finalidade de aumentar a mesoporosidade contribuindo como um suporte catalítico efetivo. Além disso, também foi possível verificar que a amostra A23 apresentou uma maior cristalinidade, verificada pela elevada intensidade de pico, quando comparada com a amostra A24 e segundo a literatura, quanto maior a cristalinidade, mais sítios ativos apresentará o material. Outro fator que foi levado em consideração foi a existência de uma diferenciação na composição química entre os catalisadores A23 e A24. O catalisador A24 apresenta um maior teor de ferro o qual provavelmente dificultou seu uso na catálise. Rodrigues(2006), diz que o comportamento catalítico de materiais argilosos é governado pela extensão e natureza da superfície externa, que ao ser modificada por tratamentos químicos e térmicos, aumenta a atividade catalítica e adsorvente de minerais argilosos; mas, tratamentos muito fortes diminuem essa atividade, logo, conforme discutido nos resultados de FRX, a severidade do tratamento aplicada a argila A24 provavelmente confirmou a diminuição de sua atividade catalítica. Um outro parâmetro que favoreceu a adsorção da argila A23 foi o fato da mesma apresentar uma área superficial maior (confirmada pela análise de BET) que a amostra A24. Pois trabalhos realizados por Rodrigues 
(2006), mostraram que quanto maior a área disponível para adsorção, mais eficiente será o catalisador.

6) Por fim, trabalhos realizados com catalisadores heterogêneos no LACOM- Laboratório de combustíveis e materiais da UFPB, mostraram que a forma de preparação e adição dos componentes no reator para ocorrência da reação de transesterificação, influenciaram o resultado final de conversão. Os mesmos, conseguiram demonstrar a necessidade de realizar uma ativação com álcool nesses catalisadores antes de colocá-los em contato com fração óleo/álcool. Logo, seria possível melhorar os valores de conversão (para catalisador A23) desta tese, se fosse utilizada a ordem de adição dos reagentes sugerida pelos pesquisadores da UFPB, ficando a sugestão para trabalhos futuros na área.

Para os valores obtidos a partir da cromatografia gasosa, Candeia (2008) ressaltou que a reação de transesterificação ocorre em três etapas. Inicialmente, a molécula de triacilglicerídeo é convertida em diacilglicérideo, depois em monoacilglicerídeo e finalmente, em glicerol, produzindo um mol de éster a cada etapa reacional e liberando a glicerina como co-produto. Diante disto, analisando-se a tabela 32 observou-se que das 16 composições de biodieseis, os valores foram elevados para os teores de mono, di e triacilglicerídeos, razão já discutida anteriormente e atribuída principalmente à baixa razão molar utilizada para os biodieseis em estudo nessa tese. O melhor resultado observado foi para o catalisador A23, quando utilizado com as condições da composição C5 ( $T=200^{\circ} \mathrm{C}, \mathrm{t}=$ $60 \mathrm{~min}$, etanol). Mais uma vez esse resultado mostrou que faz-se necessário um ajuste dos parâmetros físicos e químicos do processo de produção do biodiesel, quando se utiliza catalisadores a base de argila. Diante deste princípio, foi possível observar que mesmo não tendo trabalhado nessa tese com parâmetros otimizados para esse tipo de catalisador heterogêneo, foi verificado que argilas ácidas podem ser utilizadas na catálise de forma eficiente no processo de produção do biodiesel, sendo portanto mais uma opção tecnológica de utilização desses catalisadores no biodiesel. 


\subsubsection{CONCLUSÕES OBTIDAS}

Diante dos resultados obtidos pode-se concluir que:

- As condições de reações utilizadas por Silva (2007), não reproduziram um bom resultado para este trabalho. Mesmo assim, foi possível obter dois materiais argilosos (A23 e A24) com potencial para catálise.

- Os resultados de caracterização físico-química e mineralógica das argilas evidenciaram que a estrutura da argila influencia a sua aplicação na catálise. Sendo assim, a argila ácida A23 demonstrou ter melhores propriedades catalíticas que a amostra A24, quando utilizadas para obtenção do biodiesel.

- Utilizando o catalisador argiloso A23, foi possível obter conversões satisfatórias, observada pelos resultados demonstrados na composição C5.

- O tipo de álcool (biodiesel metílico e etílico) utilizado influencia o processo de transesterificação. Para catalisadores argilosos verificou-se que o etanol demonstrou ter melhor desempenho nas reações de transesterificações.

- As informações obtidas por cromatografia gasosa confirmaram a composição química predominantemente saturada dos ésteres de ácidos graxos, que formam o biodiesel.

- A razão molar é um fator que influencia o processo de transesterificação, razões molares mais elevadas aumentam a conversão.

- A temperatura é um fator que influencia o processo de transesterificação, para este trabalho observou-se maiores conversões quando utilizou-se $200^{\circ} \mathrm{C}$. 
- O tempo é um fator que influencia o processo de transesterificação, para este trabalho observou-se maiores conversões quando utilizou-se um tempo de 60 minutos para as reações de transesterificações .

- Para a razão molar álcool etílico: óleo $=1,76$ a melhor condição estudada foi à temperatura de $200^{\circ} \mathrm{C}$ e tempo 60 minutos de reação.

- A argila Bofe apresentou melhores propriedades catalíticas que a argila Verde Lodo.

Uma avaliação dos resultados indica que é possível obter o biodiesel a partir de catalisadores argilosos, porém investigações adicionais sobre otimização das condições experimentais, utilizando catalisadores heterogêneos são necessárias, tendo em vista a melhoria do processo de produção do biodiesel. 


\subsection{APLICAÇÃO 3 : BENTONITAS PARA NANOCOMPÓSITOS}

De acordo com Sharmasarkar et. al. (2000), as argilas organofílicas podem ser sintetizadas a partir de bentonitas sódicas (altamente hidrofílica) com a adição de sais quaternários de amônio, contendo ao menos uma cadeia com 12 ou mais átomos de carbono, em uma dispersão aquosa. Nestas dispersões aquosas as partículas elementares da argila, que são lamelas, devem encontrar-se, no maior grau possível, separadas umas das outras, facilitando a introdução dos compostos orgânicos, que irão torná-las organofílicas (VALENZUELA-DÍAZ, 1994).

Nanocompósitos são materiais que se encontram sob intensa pesquisa a nível mundial devido ao fato de possuírem um amplo potencial de uso, principalmente nas indústrias automobilísticas e de embalagens (MOREIRA, 2004).

Enquanto os compósitos poliméricos convencionais, contendo cargas minerais, são baseados em dispersões micrométricas, os nanocompósitos silicato/polímero possuem partículas minerais com ao menos uma dimensão de ordem nanométrica. E devido às espessuras das lamelas dos argilominerais terem dimensões nanométricas, ao estarem separadas por material polimérico, nos nanocompósitos, é possível verificar os efeitos sinergéticos quanto às propriedades mecânicas, térmicas e físico-químicas, quando comparadas com os polímeros puros ou os compósitos micrométricos convencionais (KOJIMA et. al., 1993).

Considerando ainda que, as borrachas vulcanizadas são normalmente reforçadas com negro de fumo (CAPONEIRO, 2002), e tendo em vista que este provém do petróleo e propicia portanto, a cor preta à borracha, além de gerar sérios problemas de poluição ao meio ambiente, é que pesquisadores têm focado atenção no desenvolvimento de novos agentes de reforço para substituir o negro de fumo (ARROYO et. al., 2003). A sílica precipitada, assim como algumas argilas tais como caulins e sepiolitas têm sido estudados como cargas, porém as propriedades de reforço têm-se mostrado inferiores ás obtidas com negro de fumo. A explicação para esse fato deve-se ao caráter inorgânico desses materiais, incompatível com as matrizes poliméricas. Poucos estudos foram realizados utilizando argilas organofílicas como cargas em borrachas. ARROYO et. al. (2003), realizaram estudos envolvendo uma esmectita modificada com sal quaternário de amônio e uma borracha natural e obtiveram nanocompósitos argila/borracha com notáveis 
melhorias nas propriedades mecânicas da borracha vulcanizada quando comparada com a borracha carregada com a mesma quantidade de negro de fumo.

Assim, quanto ao aspecto tecnológico, essa pesquisa possui alta relevância dado existirem poucos estudos, a nível mundial, sobre a obtenção de nanocompósitos argilas esmectíticas organofílicas /borrachas.

Além disso, outro fator motivante que deve ser ressaltado no desenvolvimento desta pesquisa é que o Brasil consome grande quantidade de borrachas, sendo que uma parte considerável é vulcanizada. Caso haja um determinado grau de substituição do negro de fumo por argilas organofílicas, por exemplo, na indústria de pneus, isso poderá proporcionar a essas indústrias ganhos importantes no custo/tempo de vida das peças. Essa medida também seria importante do ponto de vista ecológico dado que os pneus teriam uma vida mais longa (o que diminuiria a quantidade de peças descartadas) e também se estaria substituindo um produto derivado do petróleo (negro de fumo) com alto potencial de poluição, por um silicato, muito mais amigável do ponto de vista ecológico.

Nesta pesquisa, a argila organofílica foi empregada como carga reforçante e substituiu o negro de fumo, que vem sendo utilizado como carga nas borrachas vulcanizadas. Para esta finalidade foram preparadas argilas organofílicas, a partir de argilas nacionais, bem como, foi utilizada uma amostra de argila organofílica comercial importada como material de comparação. A matriz polimérica foi uma amostra comercial de borracha natural

\subsubsection{OBJETIVO DESSE ESTUDO}

O objetivo para realização desse trabalho foi preparar argilas organofílicas a partir da bentonita Chocobofe e obtenção de possíveis nanocompósitos argila organofílica/borracha.

\subsubsection{MATERIAIS UTILIZADOS}

Para o desenvolvimento desta pesquisa foram utilizados os materiais relacionados abaixo: 
- Amostra de bentonita não modificada nacional (policatiônica e predominantemente cálcica) proveniente do município Boa Vista, Estado da Paraíba, denominada de Chocobofe. A mesma passou por um processo de moagem no LMPSol/PMT/USP (Laboratório de Matérias-Primas Particuladas e Sólidos Não-Metálicos do Departamento de Engenharia Metalúrgica e de Materiais da EPUSP), utilizando um moinho de facas da marca Thomas Wiley modelo 4, até passagem completa na peneira ABNT $n^{\circ} 200$, com abertura de $0,075 \mathrm{~mm}$.

- Amostra de bentonita comercial sódica nacional, denominada de Fluid Gel que foi fornecida na forma particulada, passando completamente na peneira ABNT ${ }^{\circ} 200(0,075 \mu \mathrm{m})$.

- Para a realização deste trabalho foi utilizado um tipo de argila esmectítica organofílica comercial importada denominada de Cloisite 30B, comercializada pela empresa Southern Clay e fornecida pelo Engenheiro Thiago Ribeiro Guimarães aluno do mestrado em Engenharia Metalúrgica e Materiais da Universidade de São Paulo.

A denominação das amostras, antes de serem submetidas a tratamento com sal quaternário de amônio é a seguinte:

- Chocobofe não modificada $=\mathbf{C B}$

- $\quad$ Fluid Gel Comercial = FG

\subsubsection{METODOLOGIA UTILIZADA}

Visando tornar as argilas esmectíticas nacionais: Chocobofe (não modificada) e Fluid Gel (comercial sódica) mais compatíveis com a borracha (polímero) tornou-se necessário transformá-las em organofílicas (processo onde os íons de sódio presentes entre as lamelas das argilas são trocados pelo íon do sal quaternário de amônio até originar a argila organofílica). Para essa finalidade foram realizados tratamentos distintos. 
A denominação das amostras, após serem submetidas a tratamento com sal quaternário de amônio é a seguinte:

- Chocobofe Organofílica = CBO

- $\quad$ Fluid Gel Organofílica = FGO

- Cloisite 30B = C30B

Com base em trabalhos realizados por José (2003), Pereira (2003) e Silva (2005) foram utilizadas para preparação de argilas organofílicas um tipo de sal quaternário de amônio comercial denominado: Cloreto de Hexadecil Trimetil Amônio (GENAMIN-CTAC50) fornecido pela empresa Clariant, localizada em São Paulo-SP. Tomando por base os resultados de inchamento em diversos solventes orgânicos, obtidos por José, Pereira e Silva, nesta pesquisa foi utilizada apenas uma relação argila/sal: $100 \mathrm{meq} / 100 \mathrm{~g}$ de argila.

A seguir são apresentados dados sobre o sal quaternário de amônio comercial utilizado no desenvolvimento dessa pesquisa.

- Nome do Sal: Cloreto de Hexadecil Trimetil Amônio (figura 79)

- Nome comercial do Sal: GENAMIN-CTAC50

- Estrutura Química: representada através da Figura 79

- Quantidade de matéria ativa: $\approx 50 \%$

- Porcentagens em massa de cadeias com diferente número de carbonos: $94 \%$ de $\mathrm{C}_{16}, 5 \%$ de $\mathrm{C}_{14}$ e $1 \%$ de $\mathrm{C}_{12}$

- Fornecedor: Clariant /SP

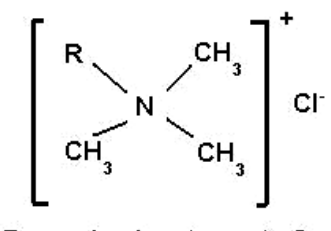

$\mathrm{R}$ - predominantemente $\mathrm{C}_{16}$

Figura 79: Estrutura química do Sal GENAMIN-CTAC50.

No desenvolver deste trabalho, esse sal será citado apenas pelo seu nome comercial (GENAMIN-CTAC50). 
A borracha natural utilizada neste trabalho foi fornecida pela Ind. de Artefatos de Borracha Esper Ltda, localizada na Rua Caramuru, 255 - VI. Conceição Diadema - São Paulo - SP. A mesma é fabricada e comercializada pela indústria Hevea Tec.

Para a preparação dos nanocompósitos utilizou-se como cargas, argilas organofílicas e negro de fumo na matriz de borracha. As formulações para confecção dos nanocompósitos também estão detalhadas abaixo na tabela 33. 
A tabela 33 apresenta as formulações empregadas no desenvolvimento deste trabalho.

Tabela 33: Formulações estudadas.

\begin{tabular}{|c|c|c|c|c|c|c|c|c|c|c|c|c|c|c|c|c|c|c|c|c|c|c|c|}
\hline \multirow{2}{*}{ Reagentes } & \multicolumn{23}{|c|}{ FORMULAÇÖES } \\
\hline & $\mathrm{F}_{1}$ & $\mathrm{~F}_{2}$ & $F_{3}$ & $\mathrm{~F}_{4}$ & $\mathrm{~F}_{5}$ & $\mathrm{~F}_{6}$ & $\mathrm{~F}_{7}$ & $\mathrm{~F}_{8}$ & $\mathrm{~F}_{9}$ & $F_{10}$ & $F_{11}$ & $F_{12}$ & $F_{13}$ & $F_{14}$ & $F_{15}$ & $F_{16}$ & $F_{17}$ & $F_{18}$ & $F_{19}$ & $F_{20}$ & $F_{21}$ & $F_{22}$ & $\mathrm{~F}_{23}$ \\
\hline $\begin{array}{l}\text { Borracha } \\
\text { Natural }\end{array}$ & 100 & 100 & 100 & 100 & 100 & 100 & 100 & 100 & 100 & 100 & 100 & 100 & 100 & 100 & 100 & 100 & 100 & 100 & 100 & 100 & 100 & 100 & 100 \\
\hline Óxido dezinco & 5 & 5 & 5 & 5 & 5 & 5 & 5 & 5 & 5 & 5 & 5 & 5 & 5 & 5 & 5 & 5 & 5 & 5 & 5 & 5 & 5 & 5 & 5 \\
\hline$\overline{\text { Ácido esteárico }}$ & 1 & 1 & 1 & 1 & 1 & 1 & 1 & 1 & 1 & 1 & 1 & 1 & 1 & 1 & 1 & 1 & 1 & 1 & 1 & 1 & 1 & 1 & 1 \\
\hline Enxofre & 2,5 & 2,5 & 2,5 & 2,5 & 2,5 & 2,5 & 2,5 & 2,5 & 2,5 & 2,5 & 2,5 & 2,5 & 2,5 & 2,5 & 2,5 & 2,5 & 2,5 & 2,5 & 2,5 & 2,5 & 2,5 & 2,5 & 2,5 \\
\hline MBTS & 0,5 & 0,5 & 0,5 & 0,5 & 0,5 & 0,5 & 0,5 & 0,5 & 0,5 & 0,5 & 0,5 & 0,5 & 0,5 & 0,5 & 0,5 & 0,5 & 0,5 & 0,5 & 0,5 & 0,5 & 0,5 & 0,5 & 0,5 \\
\hline TMTD & 0,5 & 0,5 & 0,5 & 0,5 & 0,5 & 0,5 & 0,5 & 0,5 & 0,5 & 0,5 & 0,5 & 0,5 & 0,5 & 0,5 & 0,5 & 0,5 & 0,5 & 0,5 & 0,5 & 0,5 & 0,5 & 0,5 & 0,5 \\
\hline BANOX H & 1 & 1 & 1 & 1 & 1 & 1 & 1 & 1 & 1 & 1 & 1 & 1 & 1 & 1 & 1 & 1 & 1 & 1 & 1 & 1 & 1 & 1 & 1 \\
\hline$\overline{C B}$ & --- & 2,5 & --- & --- & --- & --- & --- & --- & --- & --- & --- & $--\cdot$ & --- & --- & --- & --- & 10 & --- & --- & --- & --- & --- & --- \\
\hline FG & --- & --- & 2,5 & --- & --- & --- & --- & 5,0 & --- & --- & --- & --- & --- & --- & --- & --- & --- & 10 & --- & --- & --- & --- & --- \\
\hline CBO & --- & --- & +-- & 2,5 & +-- & --- & +-- & --- & 5,0 & --- & --- & $\cdots$ & 7,5 & $\cdots-$ & $\cdots$ & $\cdots$ & --- & +-- & 10 & --- & --- & --- & --- \\
\hline FGO & --- & --- & --- & --- & 2,5 & --- & --- & --- & --- & 5,0 & --- & 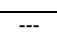 & --- & 7,5 & 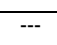 & $\cdots$ & --- & --- & --- & 10 & --- & --- & --- \\
\hline C30B & $-\cdots$ & $-\cdots$ & $\cdots$ & $\cdots-$ & $-\cdots$ & 2,5 & --- & $\cdots$ & --- & $\cdots$ & 5,0 & $\cdots$ & $-\cdots$ & -- & 7,5 & $\cdots$ & $\cdots$ & --- & --- & --- & 10 & -- & --- \\
\hline $\mathrm{NF}$ & --- & --- & --- & --- & --- & --- & 2,5 & --- & --- & --- & --- & 5,0 & $\cdots-$ & $\cdots-$ & $\cdots$ & 7,5 & --- & --- & --- & --- & --- & 10 & 20 \\
\hline
\end{tabular}

MBTS- Disulfeto de benzotiasil;TMTD- Disulfeto de tetrametiltiurama;CB - Argila não modificada;FG - Argila não modificada (comercial sódica);CBO - Argila organofílica fabricada em laboratório (partindo-se da amostra de argila não modificada);FGO - Argila organofílica fabricada em laboratório (partindo-se da amostra de argilamodificada comercialmente com sódio);C30B - Argila organofílica comercial importada;NF- Negro de fumo ; A unidade utilizada para quantificar todos os reagentes foi pcr (partes por 100 partes de resina). Nesta tabela $1 \mathrm{pcr}=1 \mathrm{~g}$. 
Analisando as formulações apresentadas na tabela 33 é possível verificar que não houve variação de alguns componentes das amostras, ou seja, os teores de borracha natural e aditivos foram fixados, já que o estudo da influência desses teores sobre a composição do provável nanocompósito não era alvo dessa pesquisa. Logo, utilizou-se para todas as 23 formulações a quantidade fixa de:

- 100 pcr de Borracha Natural

- 1 pcr de Ácido Esteárico (ativadores )

- 5 pcr de Óxido de Zinco (ativadores )

- 0,5 pcr de Disulfeto de Benzotiasil (aceleradores)

- $0,5 \mathrm{pcr}$ de Disulfeto de Tetrametiltiurama (aceleradores)

- 1 pcr de Banox H (antioxidante)

Para diferenciar essas composições foi variado o teor e o tipo de carga, visando analisar a influência dos mesmos sobre as propriedades mecânicas dos materiais obtidos. As cargas utilizadas foram:

- $\mathbf{C B}$ - Argila não modificada

- FG - Argila não modificada (comercial sódica)

- CBO - Argila organofílica fabricada em laboratório (partindo-se da amostra de argila não modificada)

- FGO - Argila organofílica fabricada em laboratório (partindo-se da amostra de argila modificada comercialmente com sódio)

- C30B - Argila organofílica comercial importada

- NF - Negro de fumo

Quanto aos teores de carga foi realizado um estudo para variarmos o teor de carga na proporção de 2,5 pcr de carga para 100 pcr de borracha natural. Logo, para esse trabalho foram estudadas as seguintes proporções de carga: $2,5 \mathrm{pcr} ; 5,0 \mathrm{pcr}$; 7,5 pcr e 10 pcr para 100pcr de borracha natural. $O$ teor de 20 pcr de negro de fumo apresentado na formulação de no 23 (tabela 33 - F23) serviu apenas como parâmetro de referência para compararmos os nossos resultados com os obtidos por Arroyo (2003).

Outro fato a ser observado é que a formulação de №1 (tabela 33 - F1), por se tratar de um material que não possui carga, foi utilizada como material comparativo no que se refere as propriedades mecânicas. A partir de todas essas 23 formulações 
foram conformadas mantas, posteriormente vulcanizadas, preparados os corpos de prova e submetidos à caracterização.

Baseados em estudos anteriores (ARROYO, 2003) e utilizando as formulações descritas na tabela 33, foram conformadas as mantas de borracha. Para esta finalidade, utilizou-se aproximadamente $0,1 \mathrm{~kg}(100 \mathrm{pcr})$ de borracha natural em todas as formulações. As mesmas foram processadas à quente por cerca de 5 min em um laminador de dois cilindros da marca Luxor e o modelo MBL 500 por cerca de 5 min em um laminador (ver figura 80). A temperatura variou de $40^{\circ}-50^{\circ} \pm$ $5^{\circ} \mathrm{C}$. A velocidade dos rolos foi de aproximadamente $17 \mathrm{rpm}$ e $15 \mathrm{rpm}$ para 0 primeiro e o segundo rolo respectivamente. A velocidade diferente é explicada pela relação de fricção que tem que ser mantida para que haja a quebra das estruturas da borracha.

Inicialmente todos os aditivos (ativadores, aceleradores e antioxidantes) foram pesados em um recipiente de polietileno (figura 80), com exceção do enxofre.

Em seguida, após ter havido a quebra das estruturas da borracha, a mesma já se apresentava num formato de manta e começou-se então a adicionar os aditivos. Os mesmo ficaram sendo processados no laminador (à temperatura de $40^{\circ}$ $50^{\circ} \pm 5^{\circ} \mathrm{C}$ ) por cerca de 10 min até atingirem uma homogeneização visual completa dos aditivos sobre a manta.

Após esse tempo foi adicionada a quantidade de carga específica para cada formulação (consultar tabela 33) e por fim, foi adicionado o enxofre. O enxofre foi adicionado no final do processo por se tratar de um agente de vulcanização, pois o mesmo quando adicionado à borracha sob presença de temperatura, reage com as ligações olefílicas das cadeias principais e periféricas das borrachas iniciando o processo de formação das reticulações (ligações cruzadas), ou seja, dando início ao fenômeno chamado de pré-vulcanização.
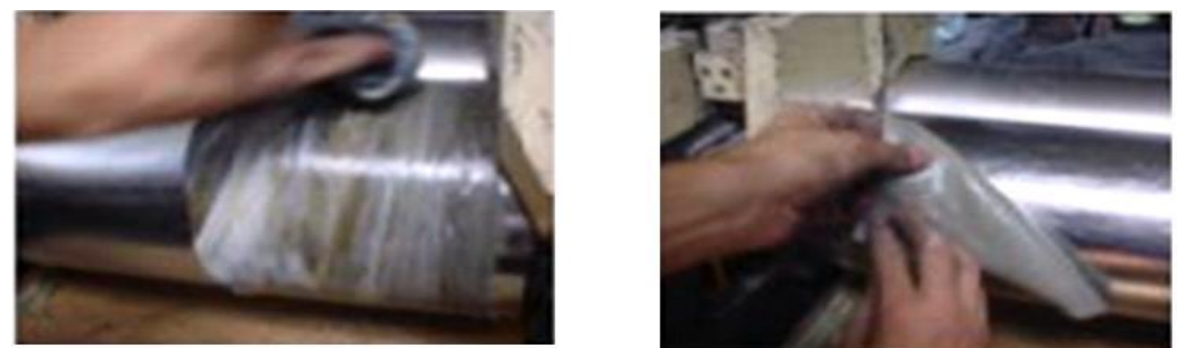

Figura 80: Esquema ilustrativo do processo de preparação das mantas.

Fonte: Adriana Silva, (2005). 
Após 5 min de laminação do enxofre com a manta de borracha, verificou-se um aspecto visual bastante homogêneo, sendo, portanto encaminhadas para vulcanização (figura 81a).

A vulcanização foi efetuada em prensa aquecida a uma temperatura de $150^{\circ} \mathrm{C}$ $\pm 1^{\circ} \mathrm{C}$, originando no final do processo placas de borracha vulcanizada (figura $81 \mathrm{~b}$ ).

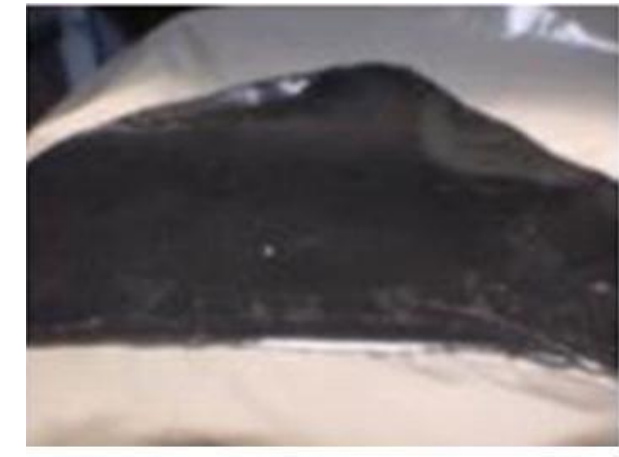

(a)

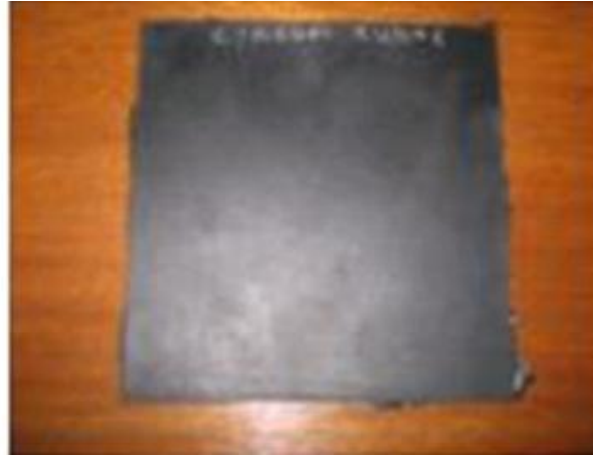

(b)

Figura 81 : (a) Manta antes da vulcanização e (b) Manta após vulcanização. Fonte: Adriana Silva, (2005).

Os corpos de prova foram cortados mecanicamente, mediante norma ASTM D 3182 (figura 82) e encaminhados para realização dos ensaios mecânicos.
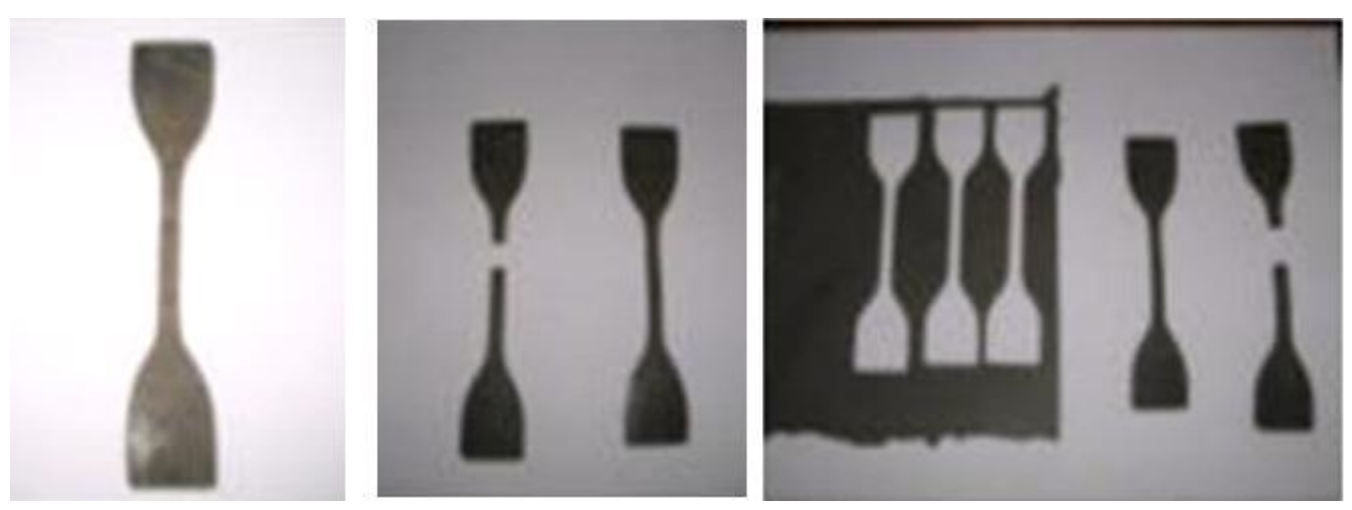

Figura 82: Corpos de prova.

Fonte: Adriana Silva, (2005). 


\subsubsection{RESULTADOS OBTIDOS}

\subsubsection{Fluorescência de Raios X (FRX)}

No tabela 34 foram apresentadas as composições químicas das amostras de argilas esmectíticas CB e FG

Tabela 34: Composição química das amostras de argilas estudadas.

\begin{tabular}{cccccccccccccc} 
Amostra & $\mathbf{S i O}_{2}$ & $\mathrm{TiO}_{2}$ & $\mathbf{A l}_{2} \mathrm{O}_{3}$ & $\mathbf{F e}_{2} \mathrm{O}_{3}$ & $\mathbf{M n O}$ & $\mathbf{M g O}$ & $\mathbf{C a O}$ & $\mathbf{N a}_{2} \mathrm{O}$ & $\mathbf{K}_{2} \mathbf{O}$ & $\mathbf{P}_{2} \mathbf{O}_{5}$ & PR & Soma \\
CB & 59,53 & 1,04 & 16,42 & 9,77 & 0,03 & 2,94 & 0,84 & 0,57 & 0,37 & 0,13 & 8,37 & 100,00 \\
FG & $\mathbf{5 9 , 6 4}$ & $\mathbf{0 , 9 0}$ & $\mathbf{1 5 , 2 7}$ & $\mathbf{8 , 3 8}$ & $\mathbf{0 , 0 5}$ & $\mathbf{2 , 8 7}$ & $\mathbf{2 , 2 9}$ & $\mathbf{2 , 3 1}$ & $\mathbf{0 , 0 5}$ & $\mathbf{0 , 0 8}$ & $\mathbf{7 , 7 1}$ & $\mathbf{9 9 , 9 9}$ \\
\hline
\end{tabular}

PR - Perda ao Rubro.

Fazendo uma análise desses resultados foi possível observar que: os teores

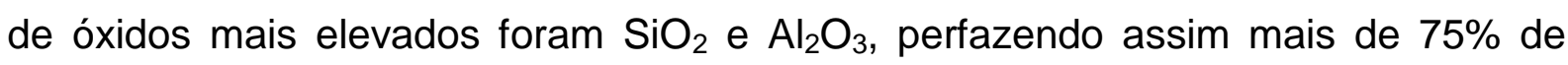
cada amostra, sendo provavelmente provenientes dos argilominerais e da sílica livre presente nas amostras, valores esses coerentes com a literatura (SOUZA SANTOS, 1992). Quanto aos valores de $\mathrm{TiO}_{2}$, verificou-se que os mesmos encontraram-se em torno de $1 \%$, não devendo alterar significativamente as propriedades tecnológicas dessas argilas. Já os teores de $\mathrm{MnO}$ e $\mathrm{P}_{2} \mathrm{O}_{5}$ situaram-se abaixo de 0,2\% para todas as amostras, não devendo ter, também, influência significativa nas propriedades tecnológicas das argilas.

Podemos observar ainda, que a amostra CB apresentou teores de $\mathrm{Na}_{2} \mathrm{O}$ na faixa de $0,57 \%$. Já a amostra FG apresentou valores na faixa de $2 \%$. O teor de óxido de cálcio variou entre 0,84\% para a amostra CB e 2,29\% para a amostra FG. A presença do cálcio em argilas montmoriloníticas ocorre geralmente na forma de cátion trocável.

Para as amostras estudadas observou-se ainda a presença de minerais de ferro com teores em torno de $8 \%$, provavelmente na forma de goetita e hematita. 
As amostras apresentaram ainda teores de $\mathrm{MgO}$ variando entre 2,94\% para a amostra CB e 2,87\% para a amostra FG; a presença desse óxido tem causa provável em possível processo de aditivação realizado na indústria.

A amostra CB apresentou um teor de $\mathrm{K}_{2} \mathrm{O}$ de $0,37 \%$, superior ao apresentado pela amostra FG de $0,05 \%$. A presença do $\mathrm{K}$ pode interferir no comportamento reológico das bentonitas, já que na secagem pode levar aos argilominerais a possuir um efeito micáceo, com colapso irreversível da distância interlamelar para valores de $0,1 \mathrm{~nm}$. Contudo, a secagem das amostras foi realizada à uma temperatura de $60^{\circ} \mathrm{C}$ e as quantidades de $\mathrm{K}_{2} \mathrm{O}$ observadas foram inferiores a $0,5 \%$, quantidade que pode ser considerada baixa.

A perda ao rubro representa a perda de água intercalada, perda de água de hidroxilas dos argilominerais, matéria orgânica e carbonatos (SOUZA SANTOS, 1992). Para as amostras em estudo, observou-se que os teores de PR variaram de 8,37\% para a amostra CB e 7,71\% para a amostra FG. Essa diferença deve-se ao fato de que a amostra CB apresentou maior teor de compostos voláteis (hidroxilas, matéria orgânica, etc.) em sua composição.

Portanto, o conjunto de resultados mostrado na tabela 34, evidenciou uma composição química típica de bentonitas provenientes de Boa Vista - PB, de acordo com estudos realizados por Souza Santos (1992).

\subsubsection{Difração de Raios X (DRX)}

A caracterização das amostras por difração de raios $X$, visou verificar a existência de minerais acessórios e de argilominerais. As figuras 83 e 84 mostraram resultados das difrações de raios $X$ para as argilas estudadas $\mathbf{C B}$ e $\mathbf{F G}$.

Analisando as curvas de raios $X$ das figuras 83 e 84 , observou-se uma reflexão do grupo da esmectítica (E), provavelmente do argilomineral montmorilonítico, que corresponde à distância basal $\left(\mathrm{d}_{001}\right)$ de 12,3Á e 15,8Á, para as amostras CB e FG respectivamente. Observou-se ainda um outro pico principal que corresponde ao mineral acessório quartzo (Q) caracterizado pelas distâncias

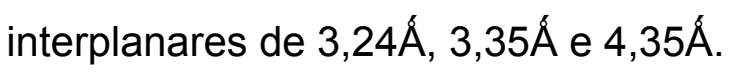




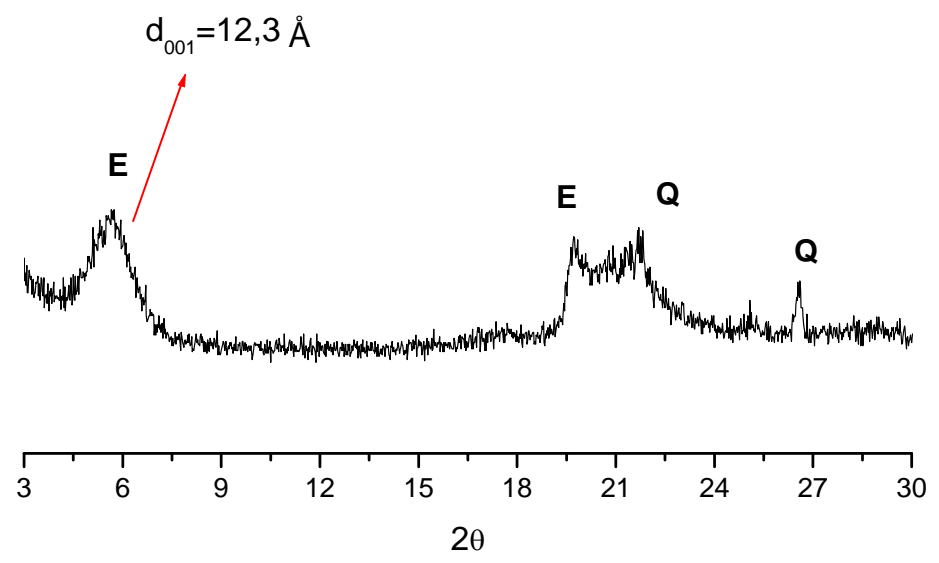

E - grupo da esmectita, Q - quartzo

Figura 83: Curvas de DRX da argila CB.

Analisando a amostra CB trata-se de uma bentonita policatiônica (predominantemente cálcica), percebeu-se através das curvas de raios $X$ que seu

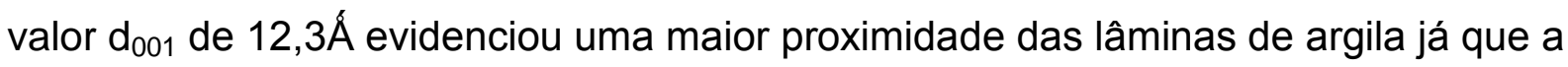
mesma não sofreu nenhum processo de tratamento.

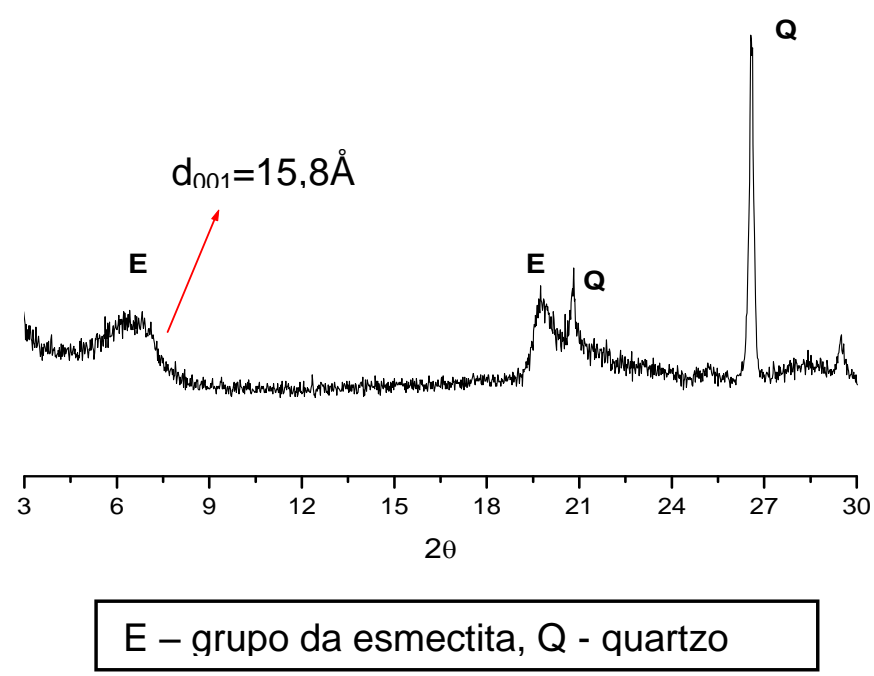

Figura 84: Curvas de DRX da argila FG.

Por se tratar de uma argila monocatiônica (sódica) a argila FG apresentou um valor de $d_{001}$ de $15,8 \AA$, evidenciando um espaçamento maior das lâminas da argila, devido ao tratamento industrial com $\mathrm{Na}_{2} \mathrm{CO}_{3}$. A expansão dessa distância interplanar 
basal deve-se a intercalação dos cátions $\mathrm{Na}^{+}$, e as suas respectivas esferas de hidratação nos espaços interplanares.

Fazendo uma análise conjunta dos espectros de difração de raios $\mathrm{X}$, podemos confirmar que a argila CB e a argila FG tratam-se de amostras de bentonitas compostas predominantemente por argilominerais do grupo das esmectitas, provavelmente montmorilonita e que as mesmas apresentaram em sua composição o quartzo como mineral acessório.

\subsubsection{Espectroscopia na Região do Infravermelho (IV)}

Na figura 85 está apresentada a espectroscopia na região do infravermelho para as amostras de bentonitas CB e FG.

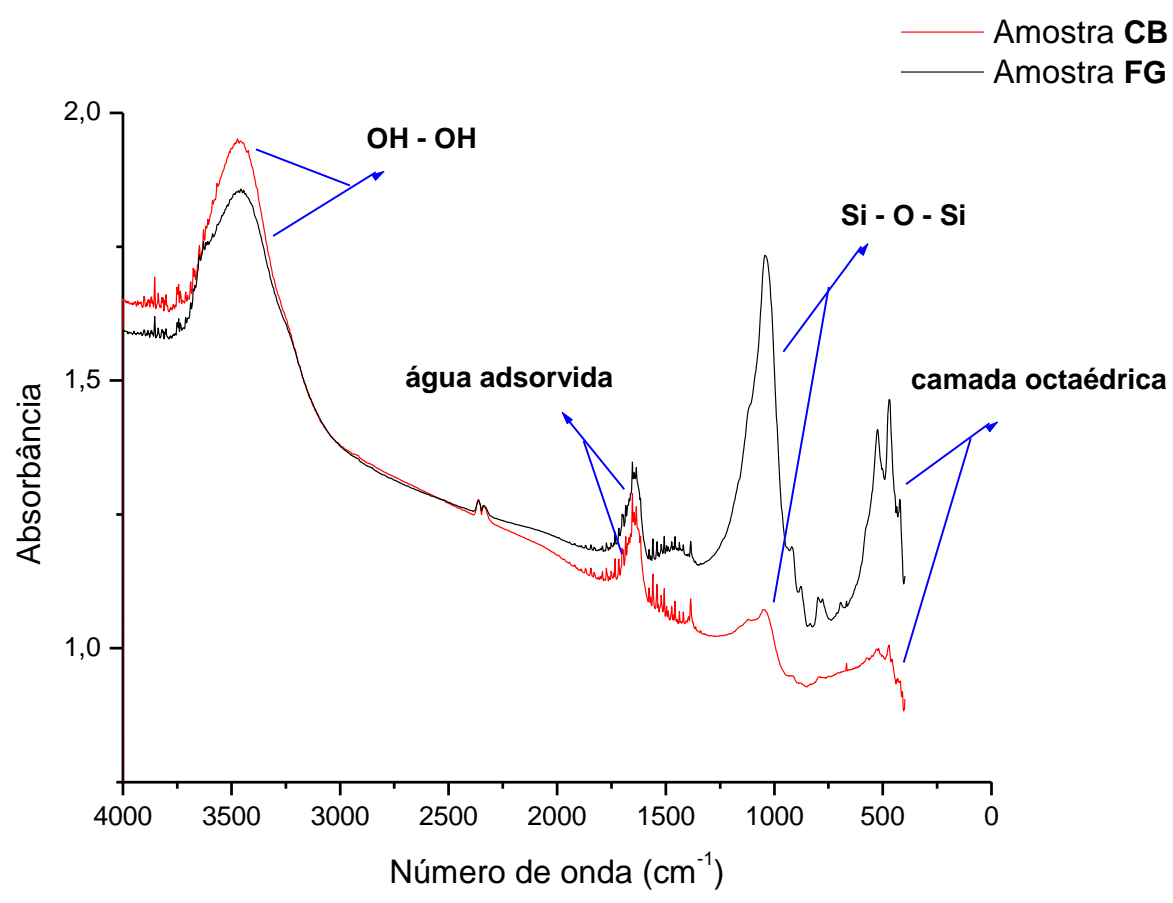

Figura 85: Espectroscopia na região do infravermelho das argilas CB e FG.

Através da observação da figura 85 podemos destacar que para a amostra CB temos as seguintes absorções: a $3510 \mathrm{~cm}^{-1}$ banda característica da presença de hidroxilas; a $1655 \mathrm{~cm}^{-1}$ banda característica de água adsorvida; a $1082 \mathrm{~cm}^{-1}$ banda característica de ligações Si-O-Si, e nas faixas de 534 e $476 \mathrm{~cm}^{-1}$ banda 
característica da camada octaédrica, o que apenas vem a confirmar que esta amostra trata-se de uma bentonita.

A amostra FG apresentou um espectro praticamente dentro da mesma faixa de comprimento de onda apresentado pela amostra CB. Comparando-se as amostras CB e FG, não foi percebida praticamente nenhuma alteração nas posições das bandas características das mesmas, já que ambas tratam-se de amostras de bentonitas oriundas da Paraíba.

$\mathrm{Na}$ tabela 35 foram apresentados de forma resumida os valores para as seguintes absorções características: da presença de hidroxilas, de água adsorvida, das ligações Si-O-Si e da camada octaédrica.

Tabela 35: Valores para as absorções características.

\begin{tabular}{|c|c|c|c|c|}
\hline ARGILA & $\begin{array}{c}\text { Banda } \\
\text { característica } \\
\text { da presença } \\
\text { de hidroxilas } \\
\left(\mathrm{cm}^{-1}\right)\end{array}$ & $\begin{array}{c}\text { Banda } \\
\text { característica } \\
\text { da presença de } \\
\text { água adsorvida } \\
\left(\mathrm{cm}^{-1}\right)\end{array}$ & $\begin{array}{c}\text { Banda } \\
\text { característica } \\
\text { da presença } \\
\text { das ligações } \\
\text { Si-O-Si }\left(\mathbf{c m}^{-1}\right)\end{array}$ & $\begin{array}{c}\text { Banda } \\
\text { característica } \\
\text { da camada } \\
\text { octaédrica } \\
\left(\mathrm{cm}^{-1}\right)\end{array}$ \\
\hline CB & 3510 & 1655 & 1082 & 534 e 476 \\
\hline FG & 3485 & 1657 & 1051 & 534,476 e 444 \\
\hline
\end{tabular}

Em resumo, percebeu-se através da tabela 35, que as amostras apresentaram bandas de absorção bastante semelhantes, o que é usual nas bentonitas da Paraíba.

\subsubsection{Microscopia Eletrônica de Varredura (MEV)}

Foram realizadas análises de microscopia eletrônica de varredura nas amostras de bentonitas CB e FG. A morfologia das argilas pode ser vista através das figuras 86 e 87 , respectivamente.

Segundo José (2003) citado por Silva (2005), uma argila lamelar seca pode ser descrita por três unidades estruturais e pelo arranjo dessas unidades no espaço: 
- A primeira unidade é a camada (partícula cristalina elementar), no caso das bentonitas de espessura de aproximadamente $7 \AA ́$ (distância interplanar de aproximadamente $10 \AA$ quando desidratadas, devido aos cátions interlamelares), e de diâmetro entre 1 e $2 \mu \mathrm{m}$.

- A segunda unidade é o tactóide que é constituído pelo empilhamento das camadas elementares.

- A terceira unidade é o aglomerado (grão), constituído por vários tactóides. Os aglomerados se organizam em "cachos" (clusters). Quando em dispersão aquosa, nas bentonitas sódicas que incham em água, com agitação mecânica adequada, os grãos vão se separando uns dos outros, formando-se em tactóides e estes vão se separando em empilhamentos contendo um pequeno número de lamelas empilhadas.

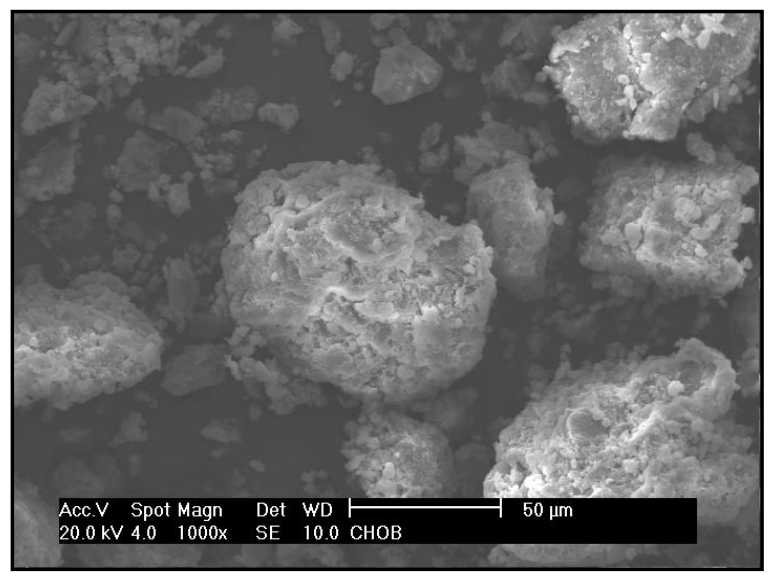

Figura 86: Micrografia da bentonita CB com um aumento 1000X (a barra corresponde a $50 \mu \mathrm{m})$.

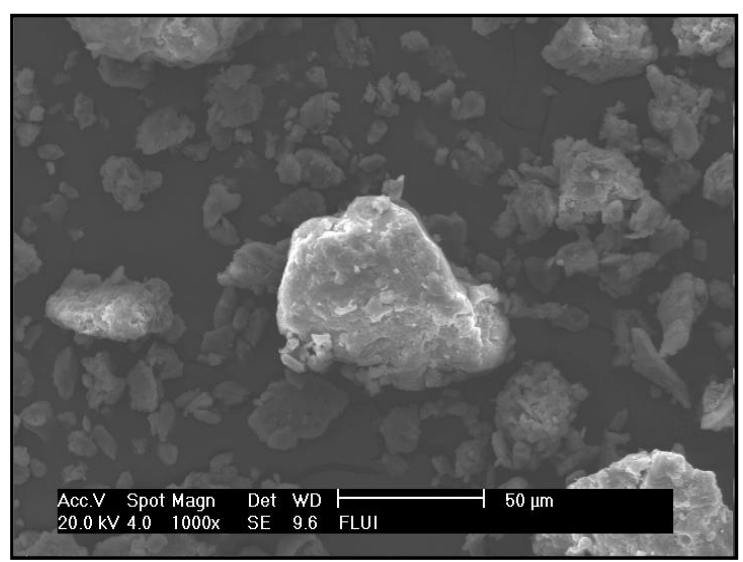

Figura 87: Micrografias da bentonita FG com um aumento 1000X(barra corresponde a $50 \mu \mathrm{m})$. 
De forma geral, a partir das observações das micrografias (figura 86 e 87) foi possível verificar que as amostras CB e FB apresentaram aglomerados com morfologia irregular, formados por tactóides não perfeitamente distinguíveis e com textura mais compacta na amostra FG. Nas duas amostras as dimensões dos aglomerados variaram entre aproximadamente 2 a 90 micrometros. Pelo analisador de imagens (tabela 36) as partículas elementares da amostra FG apresentaram um diâmetro médio inferior $(48,9 \mu \mathrm{m})$ ao da amostra CB $(68,7 \mu \mathrm{m})$.

A tabela 36 mostra o diâmetro médio dos grãos das amostras estudadas.

Tabela 36: Diâmetro médio dos aglomerados das argilas CB e FG estudadas contados a partir do programa MOCHA da Jandell (analisador de imagens).

\begin{tabular}{cc}
\hline Amostra & $\begin{array}{c}\text { Diâmetro médio dos } \\
\text { aglomerados }(\boldsymbol{\mu m})\end{array}$ \\
\hline CB & 68,7 \\
\hline FG & 48,9 \\
\hline
\end{tabular}

\subsubsection{Espectroscopia por Dispersão de Energia (EDS)}

No mesmo microscópio onde foram realizadas as microscopias eletrônicas de varredura para as amostras $\mathbf{C B}$ e FG, foram realizadas de forma a complementar e confirmar a análise de $\mathrm{FRX}$, análises para a identificação dos elementos químicos presentes através do acessório de EDS anexado ao equipamento.

A figura 88 apresenta os resultados obtidos para a amostra CB

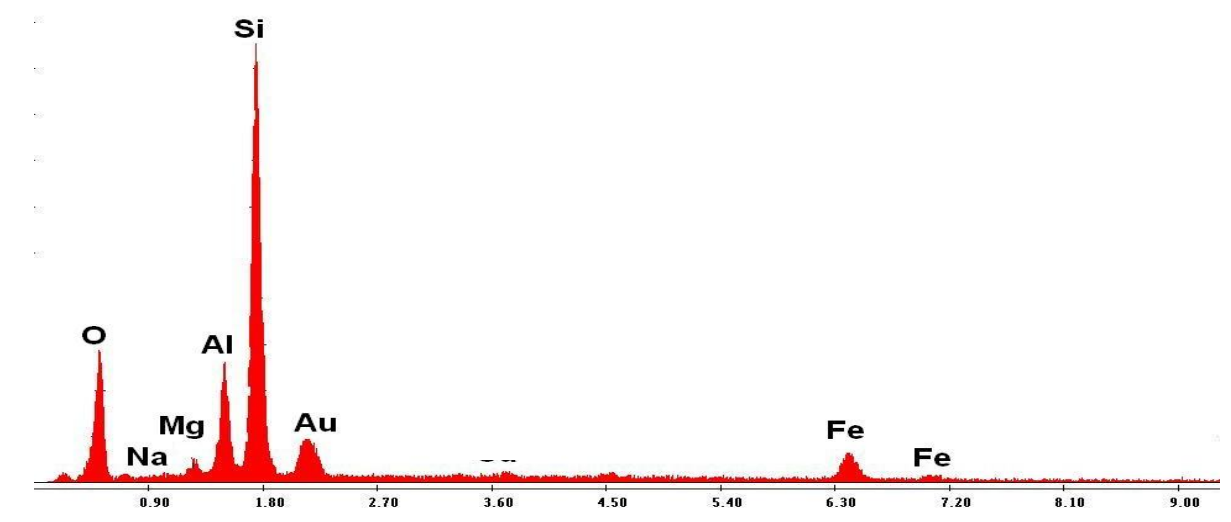

Figura 88: Espectroscopia por dispersão de energia da bentonita CB. 
Através da análise de EDS verificou-se que a amostra CB apresentou em sua composição a predominância dos elementos Si e Al, traços de $\mathrm{Na}$ e $\mathrm{Mg}$, bem como Fe, composição esta característica das argilas esmectíticas da Paraíba, conforme explicado anteriormente pela análise de FRX.

A presença do elemento Au deve-se ao recobrimento feito na amostra para a realização do ensaio.

A figura 89 apresenta os resultados obtidos para a amostra FG.

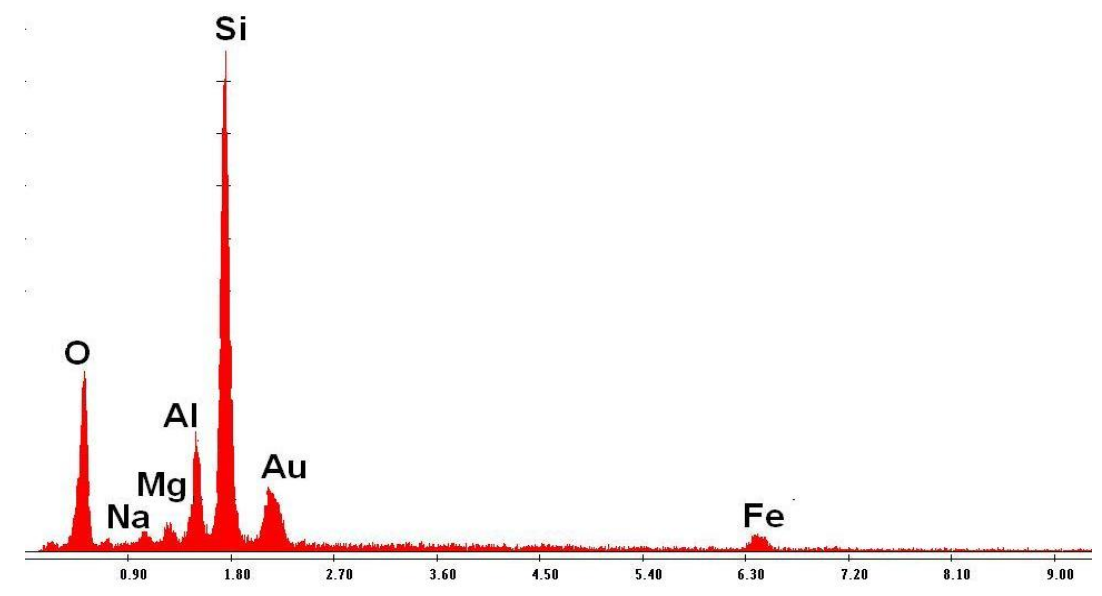

Figura 89: Espectroscopia por dispersão de energia da bentonita FG.

Comportamento análogo ao da argila CB pode ser verificado para a argila FG, onde esta apresentou em sua composição, basicamente, Si e Al, traços de $\mathrm{Na}$, Mg e $\mathrm{Fe}$.

\subsubsection{Caracterização das Argilas Organofílicas}

Nesta etapa serão abordados e discutidos os resultados das amostras de argilas organofílicas (CBO e FGO) organofilizadas em laboratório, bem como, para a argila organofílica comercial importada (C30B).

\subsection{Difração de Raios X (DRX)}


Os resultados das curvas de raios $\mathrm{X}$ das argilas organofílicas: CBO, FGO e C30B,foram apresentados nas figuras 90 a 92.

A figura 96 apresenta as curvas de raios $X$ da argila organofílica CBO.

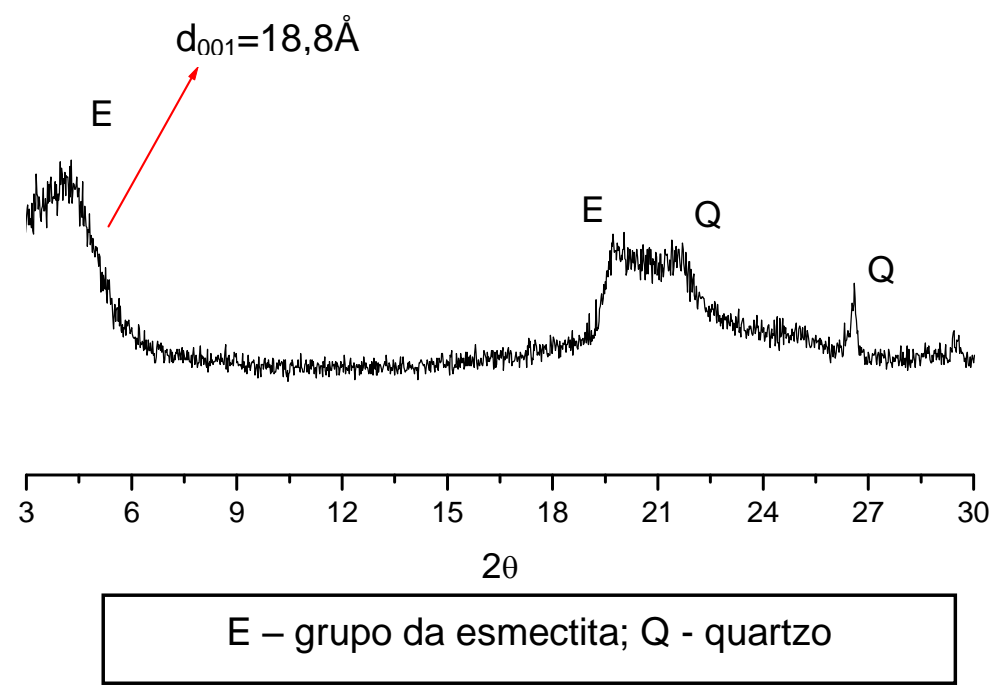

Figura 90: Curvas de raios $\mathrm{X}$ da argila organofílica CBO.

Conforme discutido anteriormente, a argila CB apresentou uma distância basal de 12,3Á. Quando modificada com o sal GENAMIN - CTAC50, a argila agora

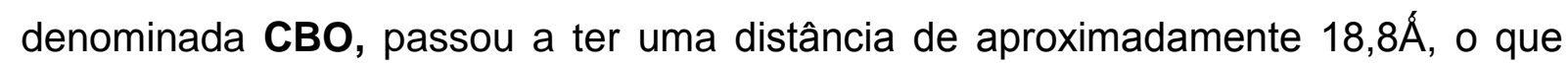
pode ser verificado na figura 90. Estes resultados evidenciaram que houve um aumento da distância basal para essa amostra, logo, pode-se dizer que o sal quaternário de amônio foi intercalado nos espaços lamelares da argila CB.

A figura 91 apresenta curvas de raios $\mathrm{X}$ da argila organofílica FGO.

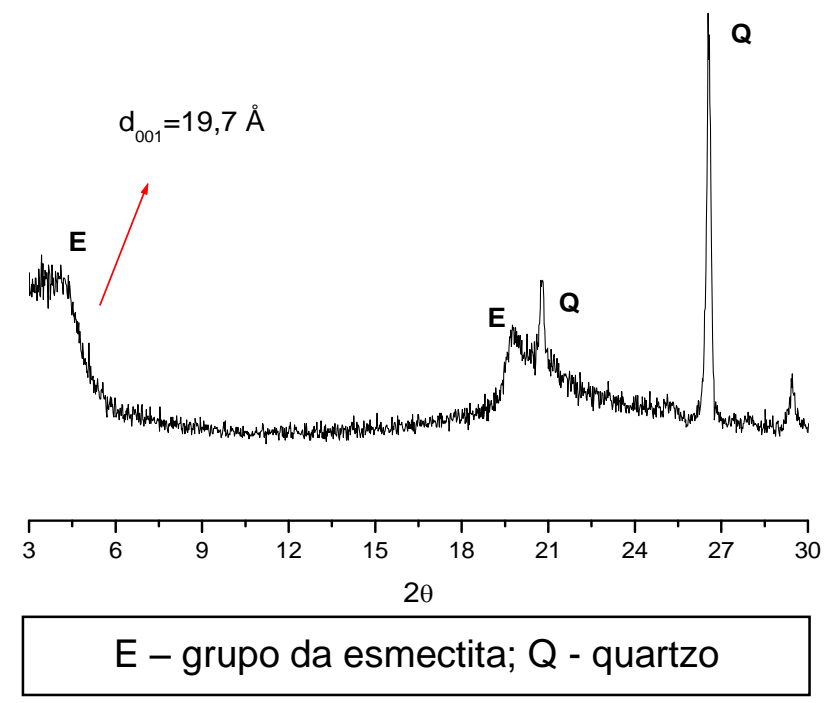

Figura 91: Curvas de raios $X$ da argila organofílica FGO. 
Conforme discutido anteriormente a argila FG apresentou uma distância basal de 15,8Á. Após ter sido modificada por um processo de organofilização, obteve-se a argila FGO, cujo valor da sua distância basal aumentou para 19,7Á, como mostra a 91. Estes resultados podem ser atribuídos à introdução dos cátions quaternários na estrutura da argila Fluid Gel.

A figura 92 apresenta o difratograma da argila organofílica comercial importada C30B.

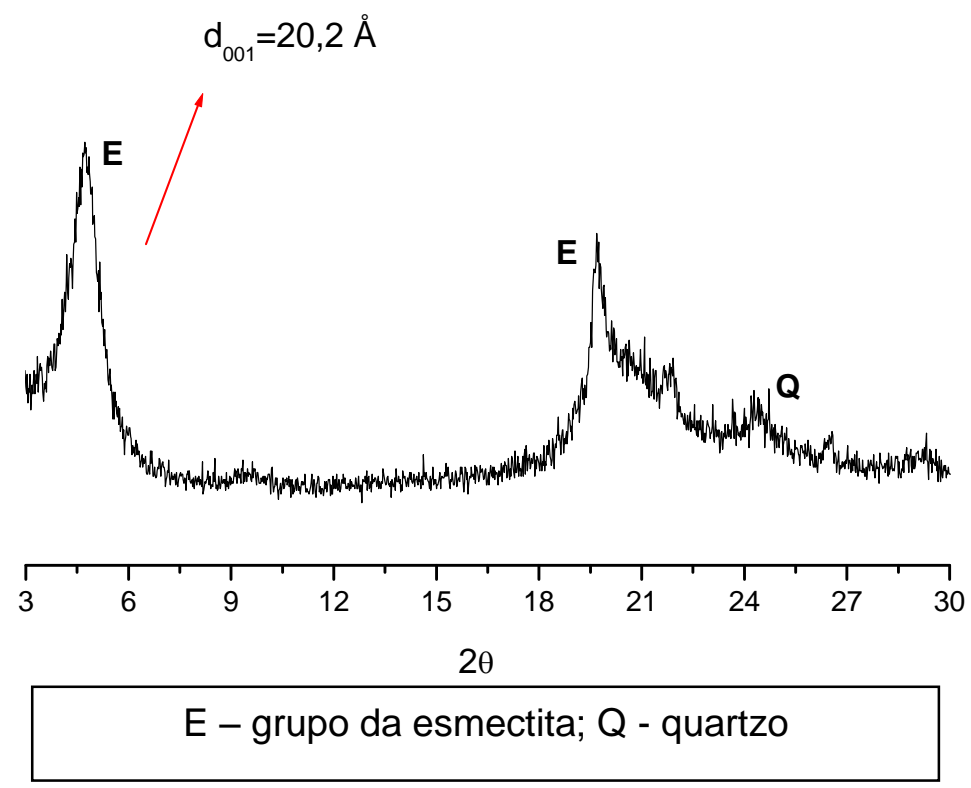

Figura 92: Difratograma da argila organofílica comercial importada C30B.

A argila organofílica comercial importada C30B, apresentou uma distância interlamelar basal $\mathrm{d}_{001}$ de 20,2Á, evidenciando que a mesma é de natureza organofílica. Quando comparada com as amostras CBO e FGO percebeu-se que a C30B apresentou um maior valor de $d_{001}$. A explicação para esse fato deve-se provavelmente ao tipo de argila utilizado, ao tipo de sal e ao processo de organofilização industrial aplicado para obtenção da mesma, pois à distância interlamelar depende do tipo da superfície da argila, isto é, da densidade de carga e do tipo de sal quaternário de amônio (quanto maior a cadeia carbônica existirá uma maior tendência de se obter maiores valores de $\mathrm{d}_{001}$ ). A tabela 37 mostra de forma resumida a variação das distâncias basais $\left(\mathrm{d}_{001}\right)$ das argilas estudadas 
Tabela 37: Variação das distâncias basais $\left(\mathrm{d}_{001}\right)$ das argilas estudadas.

\begin{tabular}{ccccc} 
Amostra & \multicolumn{4}{c}{ Distâncias basais $\left(\mathbf{d}_{001}\right)(\mathbf{A})$} \\
& $\begin{array}{c}\text { Sem } \\
\text { Tratamento }\end{array}$ & Comercial & $\begin{array}{c}\text { Organofílica } \\
\text { Preparada em } \\
\text { laboratório }\end{array}$ & $\begin{array}{c}\text { Organofílica } \\
\text { comercial } \\
\text { importada }\end{array}$ \\
CB & 12,3 & --- & --- & --- \\
FG & --- & 15,8 & --- & --- \\
CBO & --- & --- & 18,8 & --- \\
FGO & --- & --- & 19,7 & -- \\
C30B & --- & --- & --- & 20,2 \\
\hline
\end{tabular}

Para uma melhor compreensão destes resultados, a figura 93 abaixo mostra a análise conjunta das amostras não modificadas e após modificação com o sal quaternário de amônio.

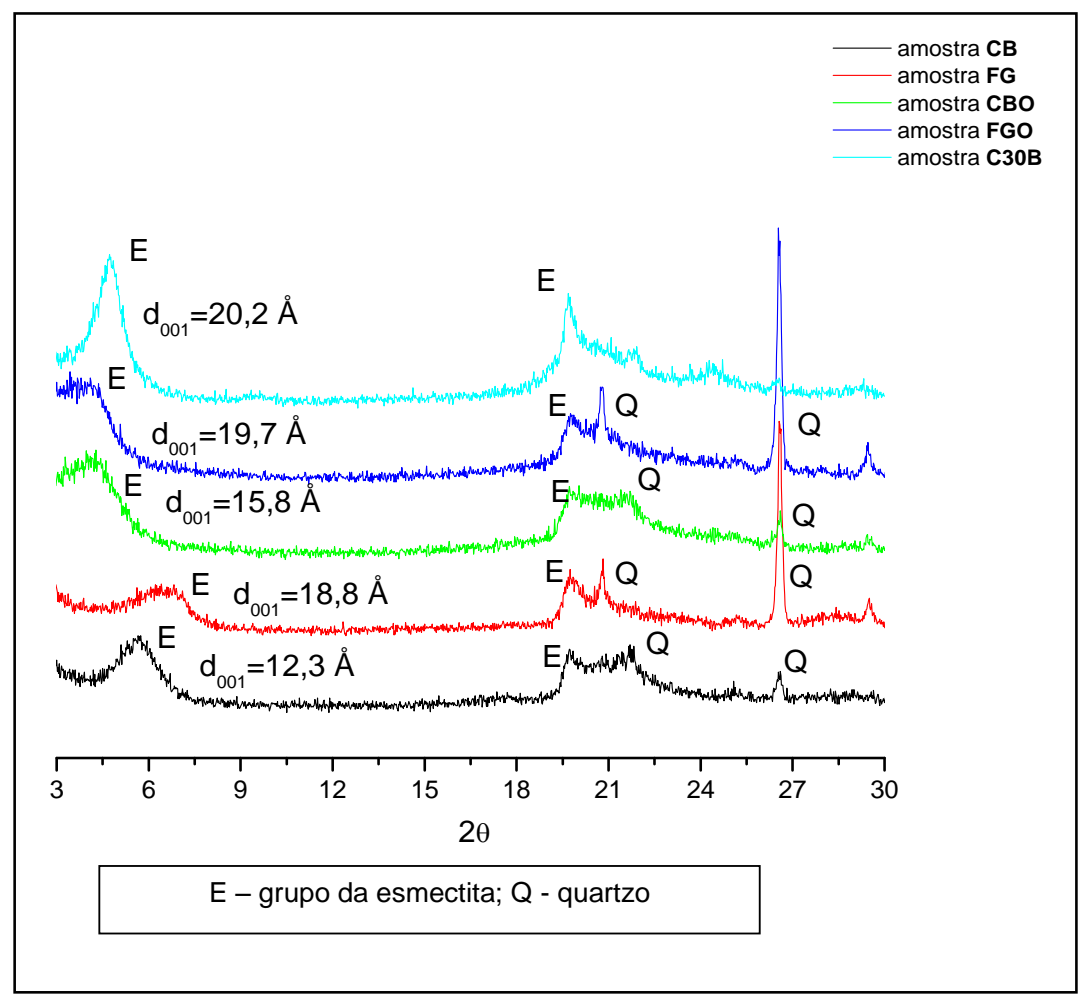

Figura 93: Análises conjuntas dos DRX de todas as argilas estudadas.

Analisando a figura 93, podemos confirmar que para as amostras modificadas em laboratório (CBO e FGO), ocorreu um deslocamento do pico 
referente à distância interplanar $d_{001}$, para ângulos menores quando comparadas com suas respectivas formas não modificadas (CB e FG). Podemos ainda verificar que em comparação com a argila $\mathbf{C} 30 \mathrm{~B}$, tida como referência, as amostras modificadas em laboratório obtiveram distâncias interplanar $d_{001}$ com valores relativamente compatíveis na faixa de 18-20Á. Confirmamos também a presença do grupo da esmectita (E) em todas as amostras estudadas, bem como a presença também do mineral acessório (Q).

\subsection{Espectroscopia na Região do Infravermelho (IV)}

$\mathrm{Na}$ figura 94 estão apresentadas as espectroscopias na região do infravermelho para as amostras de argilas organofílicas CBO, FGO е С30B.

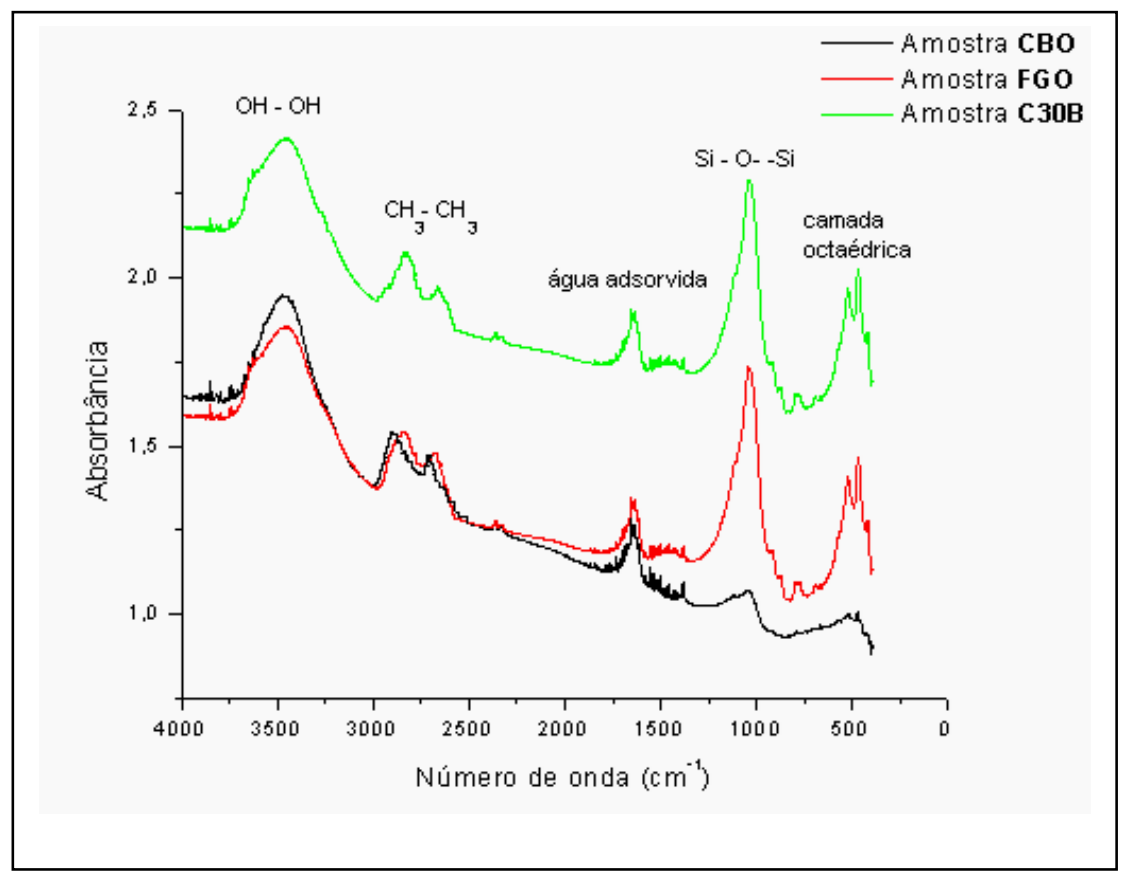

Figura 94: Espectroscopia na região do infravermelho das argilas CBO, FGO e C30B.

O espectro de absorção na região do infravermelho das argilas CBO e FGO após o tratamento com o sal quaternário de amônio, revelou a presença de novas bandas entre $2500 \mathrm{~cm}^{-1}$ e $3000 \mathrm{~cm}^{-1}$ referentes às vibrações dos grupos $\mathrm{CH}_{3}$, que fazem parte da estrutura química do sal que foi incorporado na argila.

Comparando as amostras CBO, FGO (amostras de argilas organofilizadas em laboratório) com a amostra C30B (amostra de argila organofílica comercial importada) pode-se verificar que houve semelhança em seus espectros, todas essas 
amostras passaram por um processo de organofilização, fato este evidenciado através de seus espectros de infravermelho, que exibiram a presença do grupo $\mathrm{CH}_{3}$.

\subsection{Microscopia Eletrônica de Varredura (MEV)}

Foram realizadas análises de microscopia eletrônica de varredura nas amostras de argilas organofílicas preparadas em laboratório (CBO e FGO), bem como para a argila organofílica comercial importada (C30B). A morfologia das argilas pode ser vista através das figuras 95 a 97 micrografias eletrônicas de varredura para a amostra CBO está apresentada na figura 95.

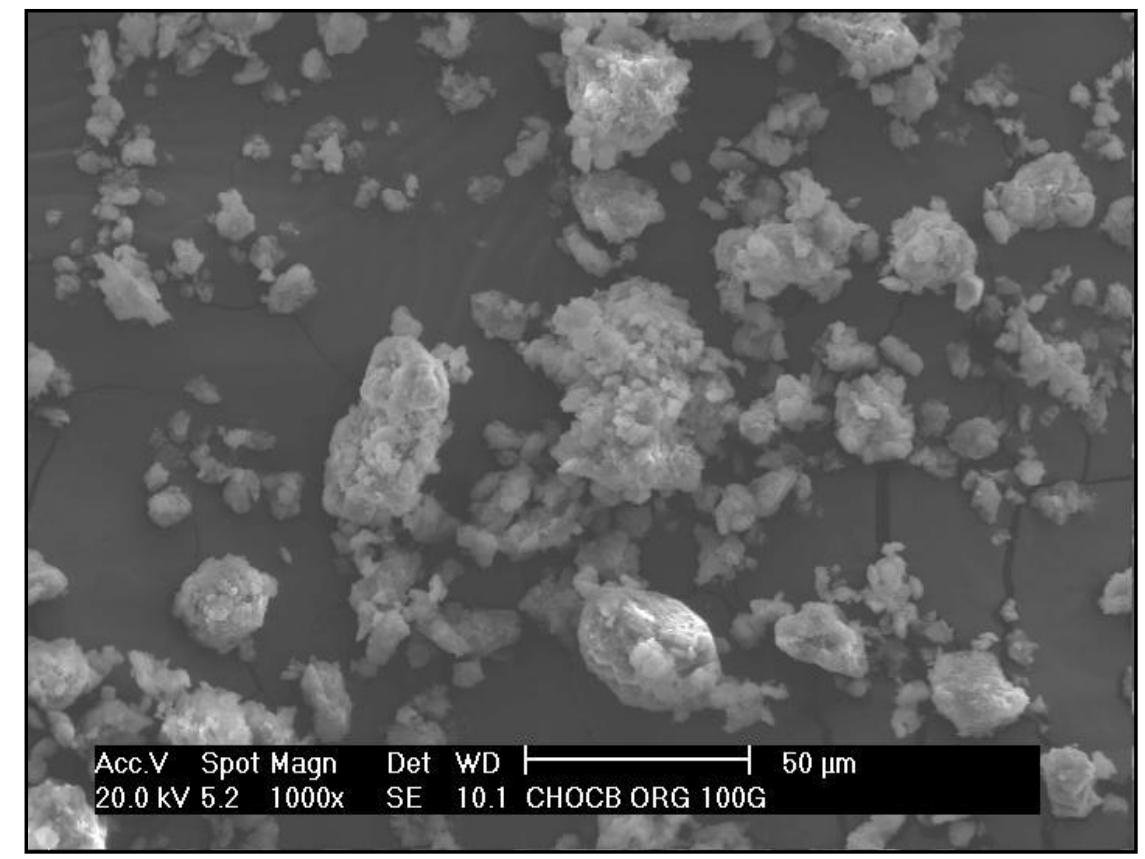

Figura 95: Micrografia da bentonita CBO com um aumento 1000X (a barra corresponde a $50 \mu \mathrm{m})$.

A partir de observações diretas da microscopia eletrônica de varredura acima (figura 95), foi possível verificar que a amostra de argila organofílica CBO, não apresentou uma distribuição homogênea do tamanho dos aglomerados, pois variaram de $2 \mu \mathrm{m}$ a $55 \mu \mathrm{m}$. No entanto em comparação com a argila $\mathbf{C B}$, podemos destacar uma redução no tamanho médio de aglomerados. 
Verificou-se ainda uma morfologia mais "aberta" (menos compacta), ou seja, notou-se também, a presença de aglomerados, porém, os mesmos apresentaram espaços vazios maiores.

A microscopia eletrônica de varredura para a amostra FGO está apresentada na figura 96.

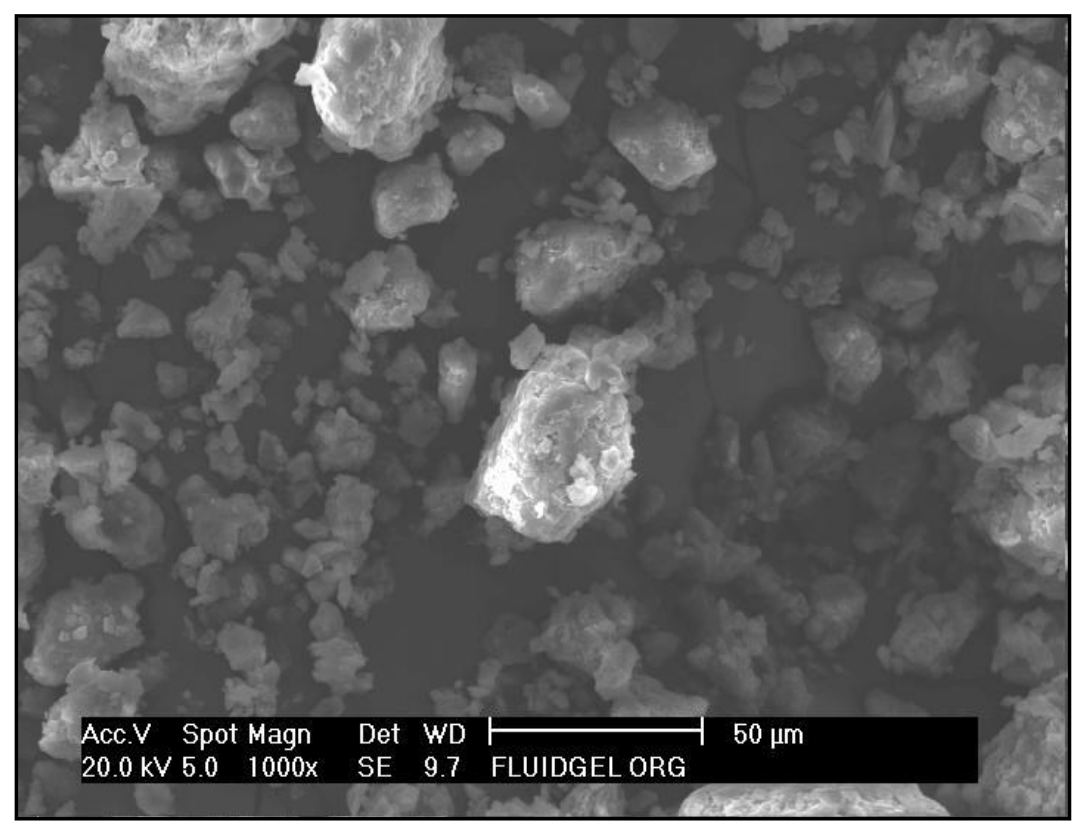

Figura 96: Micrografia da bentonita FGO com um aumento 1000X (a barra corresponde a $50 \mu \mathrm{m}$ ).

A partir da microscopia eletrônica de varredura apresentada através da figura 96, foi possível verificar que a amostra de argila organofílica FGO, não apresentou uma distribuição homogênea de aglomerados, pois apresentou aglomerados de diversos tamanhos, variando, na micrografia, de aproximadamente $2 \mu \mathrm{m}$ a $43 \mu \mathrm{m}$. Em comparação com a argila FG, podemos destacar uma redução no tamanho médio dos aglomerados.

Verificou-se ainda, a presença de aglomerados com estruturas mais "abertas", porém, os mesmos apresentaram espaços vazios maiores, comportamento esse provável ao fato da intercalação do sal quaternário de amônio nas lamelas da argila, ocasionando um aumento do diâmetro da distância basal entre os planos $\mathrm{d}_{001}$, conforme mencionado anteriormente nos resultados de DRX. Este efeito foi menor do que o observado na amostra CBO. 
A microscopia eletrônica de varredura para a amostra C30B está apresentada na figura 97.

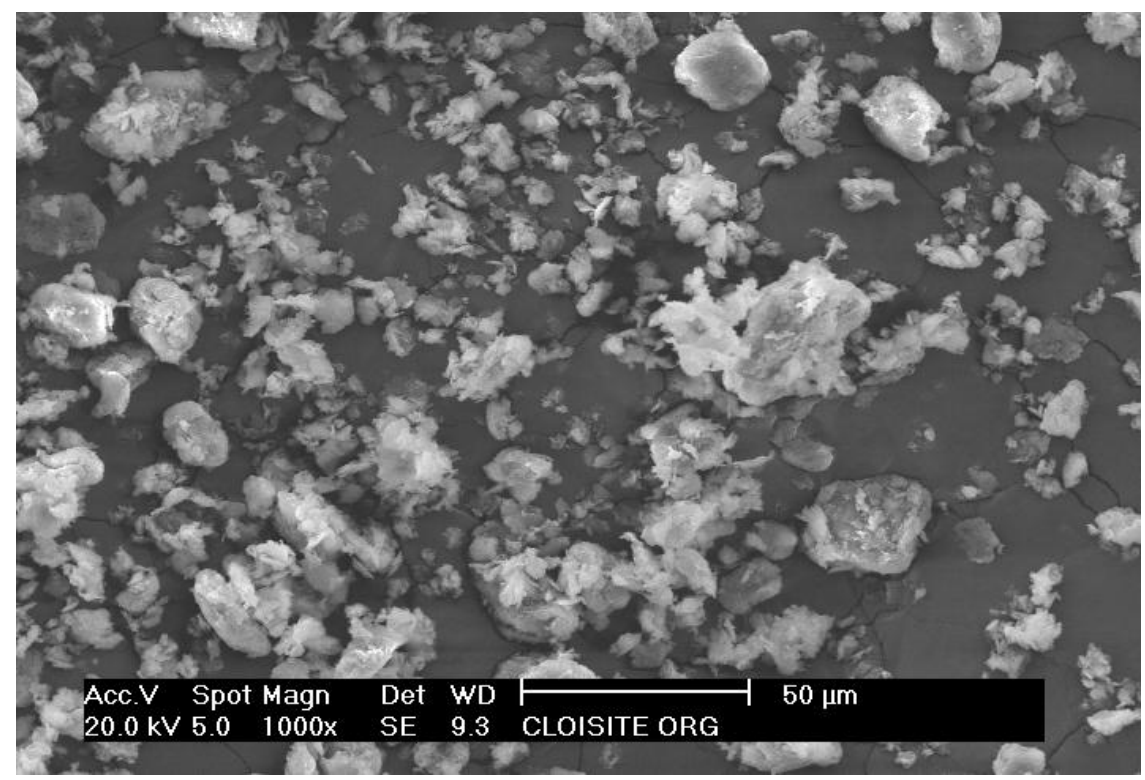

Figura 97: Micrografia da argila organofílica comercial importada C30B com um aumento 1000X (a barra corresponde a 50 $\mu \mathrm{m}$ ).

A amostra de argila organofílica comercial importada C30B, apresentou aglomerados com morfologia irregular, com dimensões variando aproximadamente entre $1 \mu \mathrm{m}$ e $36 \mu \mathrm{m}$ e diâmetro médio de aproximadamente $26 \mu \mathrm{m}$. Observou-se também uma estrutura mais aberta do que nas amostras organofílicas preparadas em laboratório, principalmente aglomerados de menores dimensões.

De forma resumida a tabela 38, mostra os diâmetros médios dos aglomerados para todas as amostras de argilas organofílicas estudadas.

Tabela 38: Variação das dimensões dos aglomerados das argilas naturais e organofílicas contados a partir do programa MOCHA da Jandell (analisador de imagens).

\begin{tabular}{ccccc} 
Amostra & $\begin{array}{c}\text { Sem } \\
\text { Tratamento }\end{array}$ & Comercial & $\begin{array}{c}\text { Organofílica } \\
\text { Preparada em } \\
\text { laboratório }\end{array}$ & $\begin{array}{c}\text { Organofílica } \\
\text { Comercial } \\
\text { Importada }\end{array}$ \\
CB & 68,75 & --- & --- & \\
FG & --- & 48,90 & --- & \\
CBO & --- & --- & 30,48 \\
FGO & --- & --- & 35,44 \\
\hline
\end{tabular}


Através da análise dos resultados da tabela 38, pudemos verificar que as amostras de bentonitas não modificadas apresentaram diâmetros médios maiores aos das respectivas amostras organofilizadas. Este comportamento indicou que o processo de organofilização provocou uma diminuição no tamanho dos aglomerados.

As amostras de argilas organofílicas obtidas em laboratório (CBO e FGO) apresentaram diâmetro médio de aglomerados maior do que a amostra de argila organofílica comercial (C30B).

\subsection{Espectroscopia por Dispersão de Energia (EDS)}

No mesmo microscópio onde foram realizadas as microscopias eletrônicas de varredura para as amostras CBO, FGO e C30B, foram realizadas análises para a identificação dos elementos químicos presentes através do acessório de EDS anexado ao equipamento.

A figura 98 apresenta os resultados obtidos para a amostra CBO.

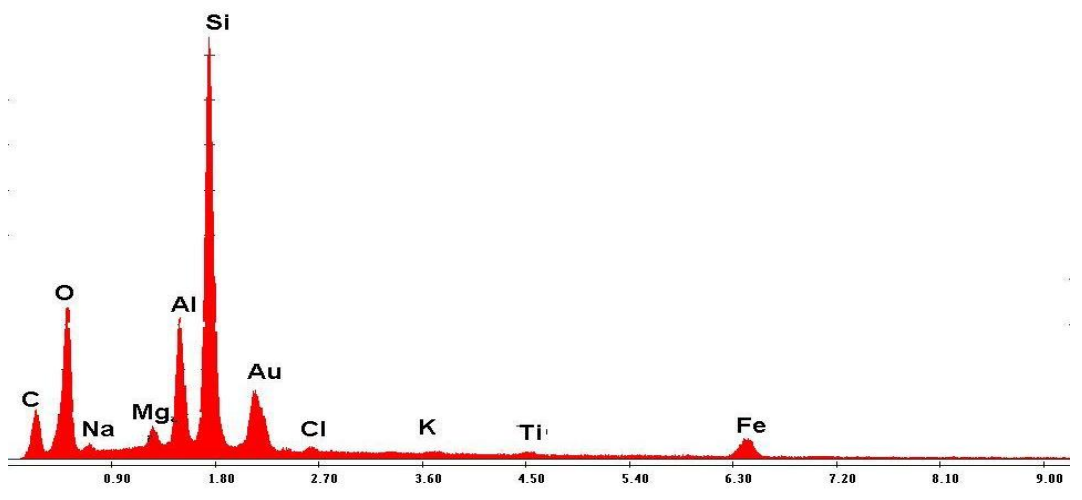

Figura 98: Espectroscopia por dispersão de energia da argila CBO. 
Através da análise de EDS verificou-se que a amostra CBO apresentou em sua composição, basicamente, Si e Al, característico de argilas esmectíticas da Paraíba. Além de traços de $\mathrm{Na}, \mathrm{K}, \mathrm{Ti}, \mathrm{Mg}$ e $\mathrm{Fe}$, também foi detectado em sua composição a presença de $\mathrm{Cl}$ e $\mathrm{C}$ confirmando a organofilização da argila.

A figura 99 apresenta os resultados obtidos para a amostra FGO.

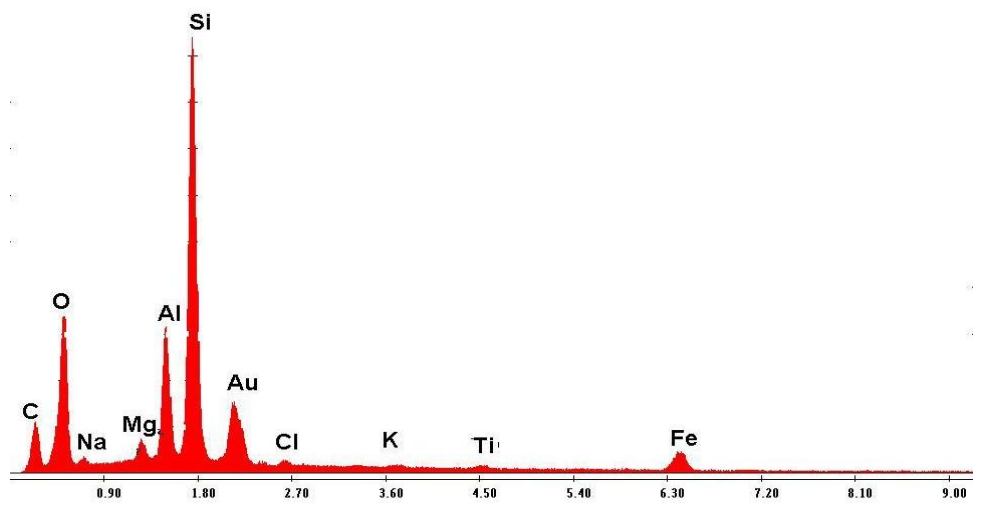

Figura 99: Espectroscopia por dispersão de energia da argila FGO.

Comportamento análogo ao da argila CBO pôde ser verificado para a argila FGO que apresentou em sua composição, basicamente, Si e Al, característico de argilas esmectíticas. Traços de $\mathrm{Na}, \mathrm{K}, \mathrm{Ti}$ e $\mathrm{Mg}$, também foram apresentados em sua composição além do $\mathrm{Fe}$. Mais uma vez a presença de $\mathrm{Cl}$ e $\mathrm{C}$ confirmou a organofilização da argila.

A figura 100 apresenta os resultados obtidos para a amostra C30B.

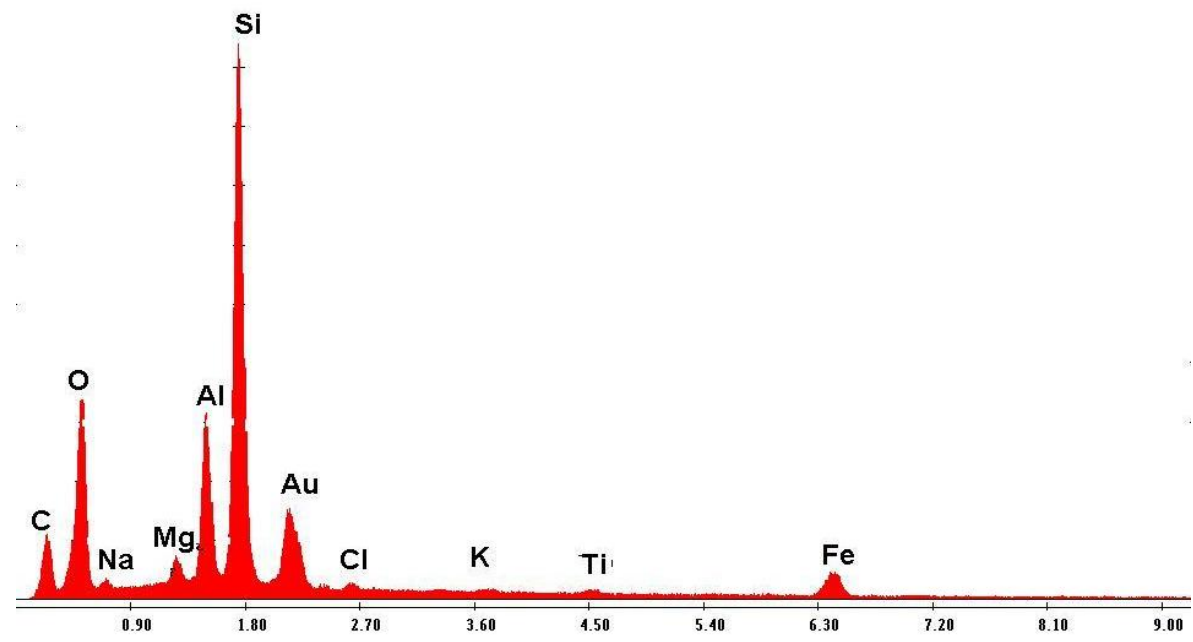

Figura 100: Espectroscopia por dispersão de energia da argila C30B. 
Através do resultado de EDS da argila C30B, verificou-se a presença predominante do Si e $\mathrm{Al}$, devido à natureza esmectítica. A presença do $\mathrm{C} \mathrm{e} \mathrm{Cl}$, devese a esta ser uma argila organofílica comercial importada. Percebeu-se ainda a presença de $\mathrm{Na}, \mathrm{Ti}, \mathrm{K}, \mathrm{Mg}$ e Fe em sua composição.

\subsubsection{Propriedades Mecânicas}

Tanto a borracha pura, quanto as mantas argila organofílica/borracha, foram submetidas a ensaios mecânicos para avaliar: resistência à tração, alongamento na ruptura, densidade e dureza, com base nas normas especificadas. A partir desses resultados, foram selecionadas as quatro melhores composições, ou seja, aquelas composições que originaram os materiais com as melhores propriedades mecânicas. Dentre as 23 formulações exibidas anteriormente, as amostras geradas a partir das formulações F19, F20, F21 e F22 foram as que apresentaram um maior destaque, evidenciando melhorias significativas de suas propriedades mecânicas. Para esse trabalho, também será dada uma maior ênfase a formulação $F_{1}$ que por se tratar de um material que não possui carga, será utilizado nas discussões desses resultados como material comparativo no que se refere às propriedades mecânicas.

$\mathrm{Na}$ tabela 39 apresenta os valores referentes às propriedades destes materiais selecionados, como também, da borracha pura obtidos nessa pesquisa.

Tabela 39: Propriedades mecânicas dos sistemas: borracha pura, argila organofílica/borracha e negro de fumo/borracha.

\begin{tabular}{c|cccc} 
Material & $\begin{array}{c}\text { Resistência } \\
\text { à tração } \\
\text { (MPa) }\end{array}$ & $\begin{array}{c}\text { Alongamento } \\
\text { na ruptura } \\
(\mathbf{\%})\end{array}$ & $\begin{array}{c}\text { Dureza } \\
\text { (shore } \mathbf{A})\end{array}$ & $\begin{array}{c}\text { Densidade } \\
\left(\mathbf{g} / \mathbf{c m}^{\mathbf{3}} \mathbf{)}\right.\end{array}$ \\
\hline $\mathbf{F}_{1}$ & $8,82 \pm 0,2$ & $750 \pm 20$ & $42 \pm 1,0$ & $0,97 \pm 0,1$ \\
$\mathbf{F}_{19}$ & $16,76 \pm 0,2$ & $650 \pm 20$ & $50 \pm 1,0$ & $1,01 \pm 0,1$ \\
$\mathbf{F}_{20}$ & $17,64 \pm 0,2$ & $650 \pm 20$ & $52 \pm 1,0$ & $1,01 \pm 0,1$ \\
$\mathbf{F}_{21}$ & $14,60 \pm 0,2$ & $675 \pm 20$ & $47 \pm 1,0$ & $1,01 \pm 0,1$ \\
$\mathbf{F}_{22}$ & $10,49 \pm 0,2$ & $625 \pm 20$ & $45 \pm 1,0$ & $1,09 \pm 0,1$ \\
\hline
\end{tabular}




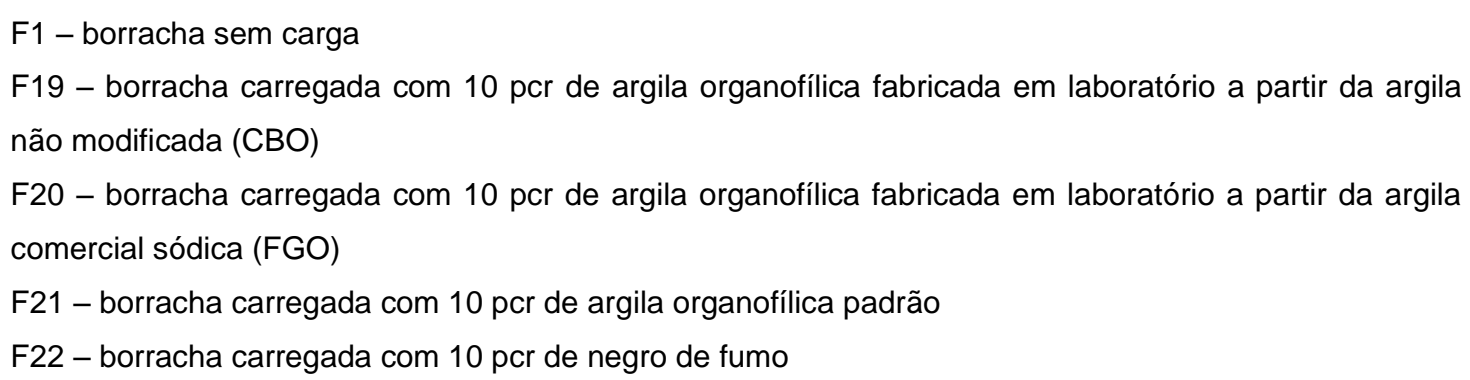

Ao observarmos na tabela 39 que foi possível verificar que os maiores valores das propriedades mecânicas foram apresentados pelos materiais que em sua formulação continham $10 \mathrm{pcr}$ de carga (argila organofílica ou negro de fumo) por 100pcr de borracha, ou seja, estes materiais (F19, F20, F21 e F22) foram os que provavelmente, tiveram uma maior interação do polímero com suas respectivas cargas, consequentemente maiores valores de suas propriedades mecânicas. Esse fato poderá ser confirmado e visualizado através das curvas de raios $X$ (também serão mostrados esses resultados a frente onde o pico das argilas organofílicas deseparece), apresentados e discutidos anteriormente mostrando que esses materiais provavelmente apresentaram uma estrutura parcialmente esfoliada, o que comprova a afinidade do polímero (borracha) com a carga (argila organofílica ou negro de fumo), fazendo com que os mesmos exibissem notáveis melhorias em suas propriedades mecânicas.

A tabela 40 apresenta os valores referentes às propriedades destes materiais selecionados, como também, da borracha pura obtidos por Arroyo (2003).

Tabela 40: Propriedades mecânicas dos sistemas: borracha pura, argila organofílica/borracha e negro de fumo/borracha obtidos por Arroyo (2003).

\begin{tabular}{ccccc} 
Material & $\begin{array}{c}\text { Resistência à } \\
\text { tração (MPa) }\end{array}$ & $\begin{array}{c}\text { Alongamento } \\
\text { na ruptura } \mathbf{( \% )}\end{array}$ & $\begin{array}{c}\text { Dureza } \\
\text { (shore } \mathbf{A})\end{array}$ & $\begin{array}{c}\text { Densidade } \\
\left(\mathbf{g} / \mathbf{c m}^{\mathbf{3}} \mathbf{)}\right.\end{array}$ \\
$\mathbf{A}_{\mathbf{1}}$ & 4,25 & $>700$ & 28,8 & 0,975 \\
$\mathbf{A}_{\mathbf{2}}$ & 15,0 & $>700$ & 43,5 & 1,004 \\
$\mathbf{A}_{3}$ & 4,93 & 464 & 30,5 & 1,014 \\
\hline
\end{tabular}

A1 - borracha sem carga

A2 - borracha carregada com 10 pcr de argila organofílica 
A3 - borracha carregada com 10 pcr de negro de fumo

Fazendo agora uma análise dos dados contidos nas tabelas 39 e 40 acima, observou-se que os resultados desta pesquisa encontraram-se de acordo com os reportados por Arroyo (2003) e que realmente houveram notáveis diferenças entre os sistemas de borracha sem e com carga. Para uma melhor compreensão dessas propriedades mecânicas, as mesmas serão analisadas separadamente através de gráficos (figuras 101, 102, 103 e 104).

A figura 101 (a) e (b) ilustra o comportamento dos sistemas estudados com relação à resistência a tração.

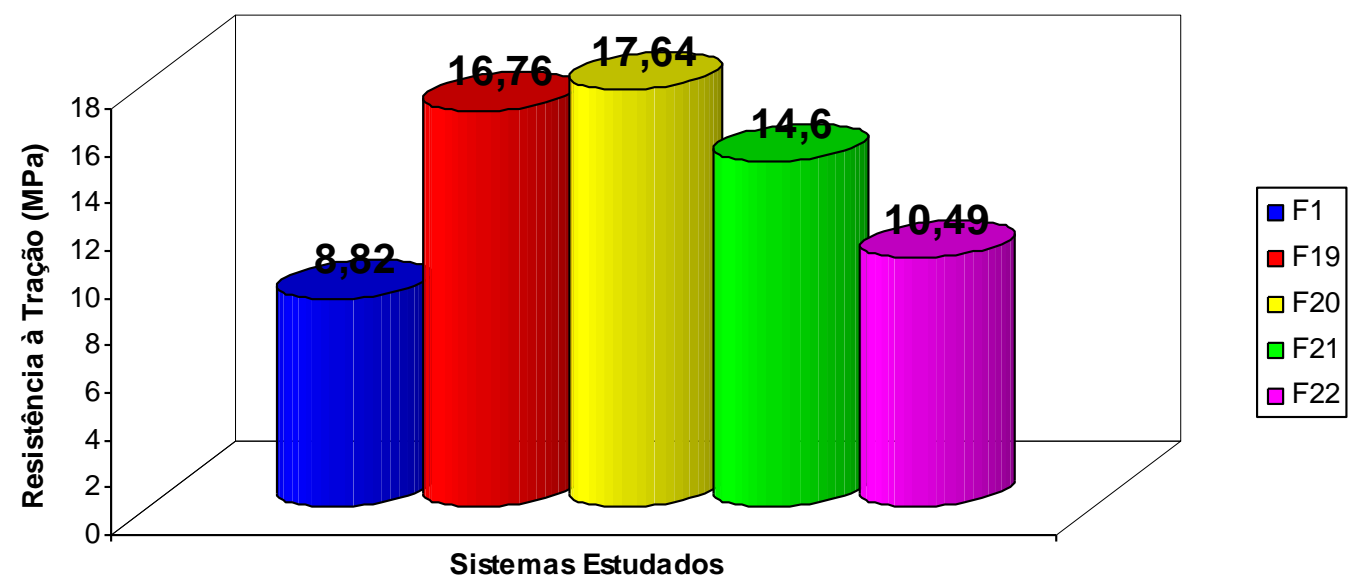

(a)

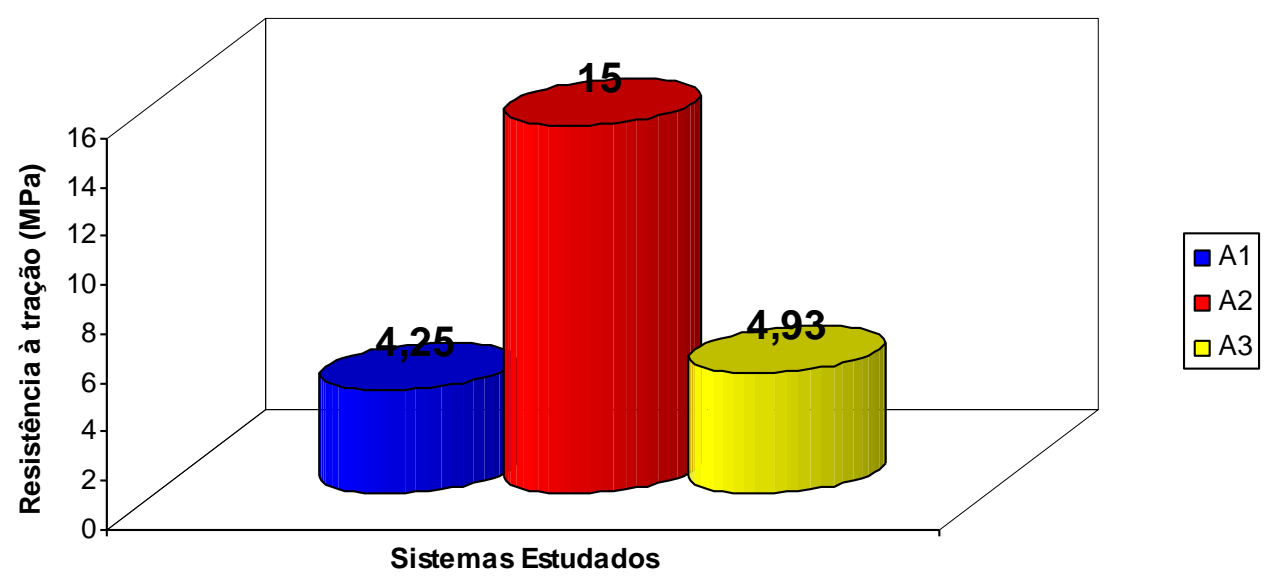

(b)

Figura 101: Resistência à tração dos sistemas estudados (a) Resultados das amostras estudadas ; (b) Resultados obtidos por Arroyo (2003). 
Analisando o gráfico acima (figura 101) verificou-se que os valores apresentados para as amostras F1, F19, F20, F21 e F22 referentes à resistência a tração sofreram alterações significativas.

A amostra F1, por se tratar de uma borracha sem carga, apresentou um valor inferior (8,82 $\mathrm{MPa})$ de resistência à tração quando comparada aos demais sistemas (carregados com partículas minerais), esse comportamento encontra-se de acordo com o reportado por Ray e Okamoto (2003), e a provável explicação para esse fato deve-se a existência de interações entre matriz polimérica e o mineral, gerando, portanto, materiais com maiores valores de sua resistência mecânica à tração. Para as amostras que utilizaram como cargas argilas organofílicas F19, F20, F21 verificou-se que houve um aumento de quase 100\% para resistência mecânica à tração e para a carregada com o negro de fumo F22 houve uma melhoria na faixa de $20 \%$. Portanto, as argilas organofílicas foram mais eficientes na matriz de borracha, atuando como cargas.

Dentre as amostras F19, F20, F21 percebeu-se que a amostra F20, que utilizou na sua composição uma argila organofílica preparada em laboratório, apresentou um maior valor de resistência à tração (17,64 MPa). A diferença nos valores observados entre as amostras que utilizaram em sua composição argilas organofílicas preparadas em laboratório e argila organofílica comercial importada, deve-se provavelmente ao fato de ter havido uma maior compatibilidade do polímero com as argilas modificadas em laboratório. O sal quaternário tem grande influencia na interação da carga com a matriz e vários estudos e estão sendo realizados verificando-se os efeitos dos sais nas preparações de nanocompósitos. Provavelmente, também houve uma melhor dispersão da argila (carga) no polímero proporcionando portanto, uma melhor interação do polímero/carga, ocasionando um aumento de resistência à tração desse material. Esse resultado torna-se interessante para esta pesquisa porque mostrou que houve uma interação do sal utilizado com a argila e que os métodos de obtenção de argila organofílica quando comparado ao da amostra de argila organofílica comercial importada foram eficientes.

Ao analisarmos a amostra F22, que utilizou o negro de fumo como carga, percebemos que quando comparada à amostra F1, a mesma apresenta destaque com relação a melhoria na resistência à tração, porém, o mesmo comportamento não foi observado quando comparada as demais amostras. As argilas organofílicas 
atuaram como melhores cargas de reforço o que pode está relacionado com o menor tamanho de partícula, assim como com os fatos citados anteriormente.

Fazendo uma comparação dos resultados de tração na ruptura obtidos nessa pesquisa, com os resultados obtidos por Arroyo (2003), verificou-se que os mesmos encontraram-se coerentes com os reportados por Arroyo, pois as amostras sem cargas apresentaram valores de resistência à tração inferiores as demais amostras. Observou-se ainda que há um aumento significativo dessa propriedade para as amostras que utilizaram argilas organofílicas como cargas.

A figura 102 (a) e (b) ilustra o comportamento dos sistemas estudados com relação ao alongamento na ruptura.

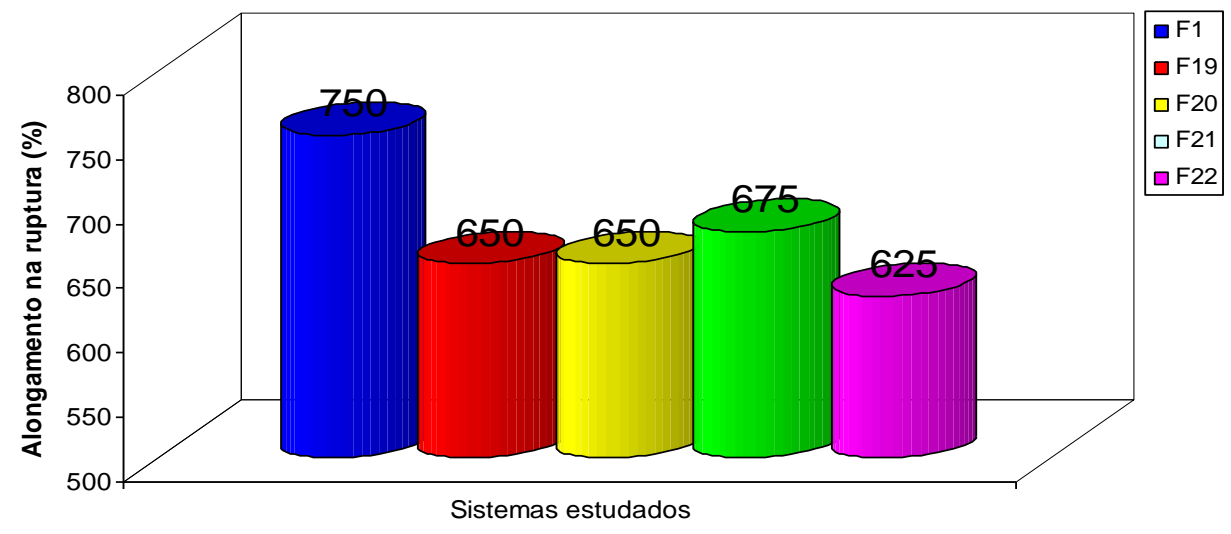

(a)

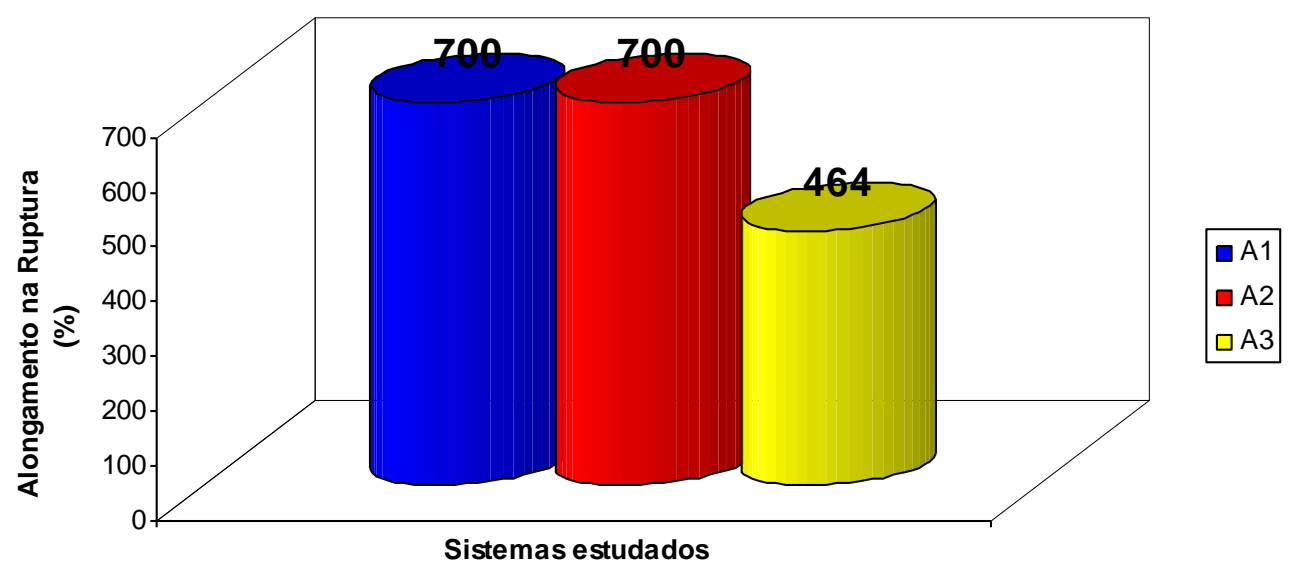

(b)

Figura 102: Alongamento na ruptura dos sistemas estudados. (a) Resultados das amostras estudadas ; (b) Resultados obtidos por Arroyo, (2003). 
Para a propriedade de alongamento na ruptura, ilustrada na figura 105, verificou-se alterações significativas de valores entre os materiais com e sem adição de cargas.

Como já era esperado, o material que apresentou um maior valor de alongamento (750\%) na ruptura foi o material considerado puro, denominado $\mathrm{F} 1$, pois por se tratar de um material sem carga, o mesmo apresenta uma maior deformação, portanto, pode alongar-se mais do que os materiais que possuem carga em sua composição.

As amostras que possuíam como cargas argilas organofílicas (F19, F20, F21) não apresentaram alterações significativas no seu alongamento à ruptura. Nas amostras que continham argila organofílica preparada em laboratório, F19 e F20, percebeu-se que não houve alteração no módulo, ficando na faixa de $650 \%$ de alongamento na ruptura. Já a amostra F21, que continha em sua composição argila organofílica comercial importada, apresentou um pequeno aumento de valor (675\%) quando comparada com as anteriores (F19 e F20). Esse resultado mais uma vez vem comprovar que realmente há uma influencia direta relacionada ao processo de preparação e ao tipo de sal incorporado nessas argilas sobre as propriedades mecânicas dos sistemas. Isso pode ser atribuído também a maior difusão de alguns segmentos moleculares do polímero dentro das camadas da argila tratada com diferentes sais. Pois as amostras de argilas organofílicas preparadas em laboratório foram tratadas com um sal denominado GENAMIM-CTAC50, enquanto a amostra de argila organofílica comercial importada foi tratada com o sal MT2ETOH, que apresenta longos grupos alquil conduzindo a uma fraca interação entre o polímero e as camadas da argila e facilitando portanto o alongamento do material.

Percebeu-se ainda que a amostra F22 foi a que apresentou um menor valor de alongamento na ruptura. Apesar dessa amostra apresentar carga em sua composição (negro de fumo), verificou-se que seu valor de alongamento é inferior ao das amostras que continham argilas organofílicas como cargas. Esse fato pôde ser explicado levando-se em consideração que o negro de fumo trata-se de uma carga que apresenta partículas esféricas na faixa nanométrica, enquanto que as argilas organofílicas apresentam partículas lamelares geralmente também na faixa nanométrica. As partículas lamelares provavelmente favorecem uma melhor interação da matriz com a carga, o que pode ser observado através da melhoria das propriedades mecânicas quando do uso das mesmas. 
Analisando os resultados de alongamento na ruptura discutidos anteriormente, com os resultados obtidos por Arroyo (2003), verificou-se que os mesmos encontraram-se dentro da faixa reportada por Arroyo, ou seja, as amostras sem cargas apresentaram valores mais significativos de alongamento (superiores a $700 \%$ ), quando comparadas às amostras com cargas (inferiores a $700 \%$ ). Observou-se ainda diferenças significativas para as amostras com cargas organofílicas e com negro de fumo.

A figura 103 (a) e (b) ilustra o comportamento dos sistemas estudados com relação à dureza.

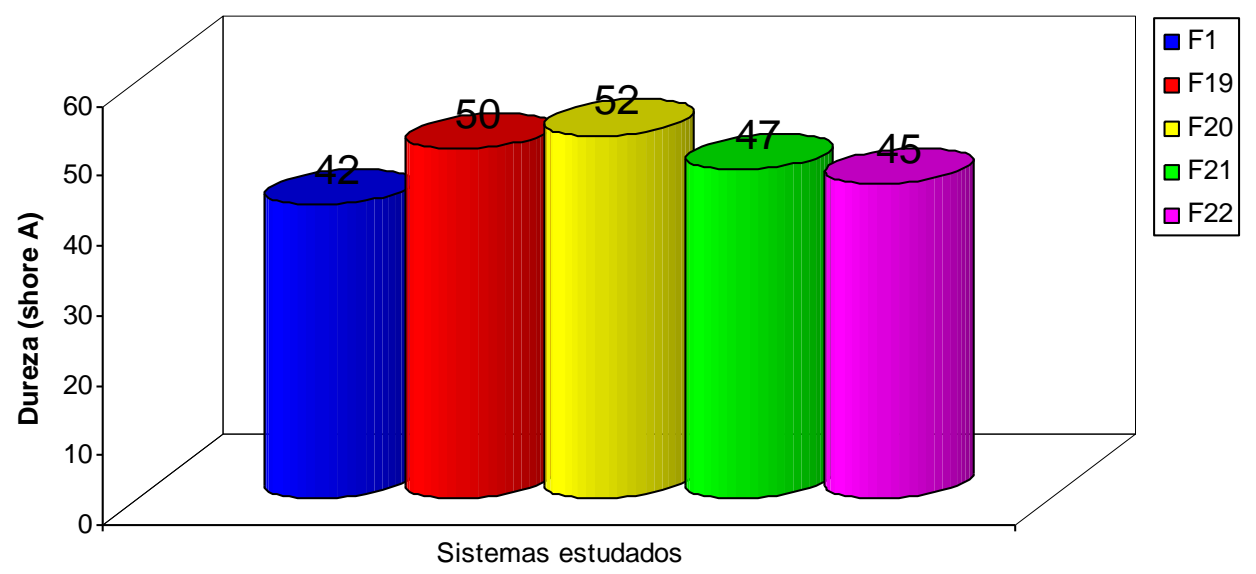

(a)

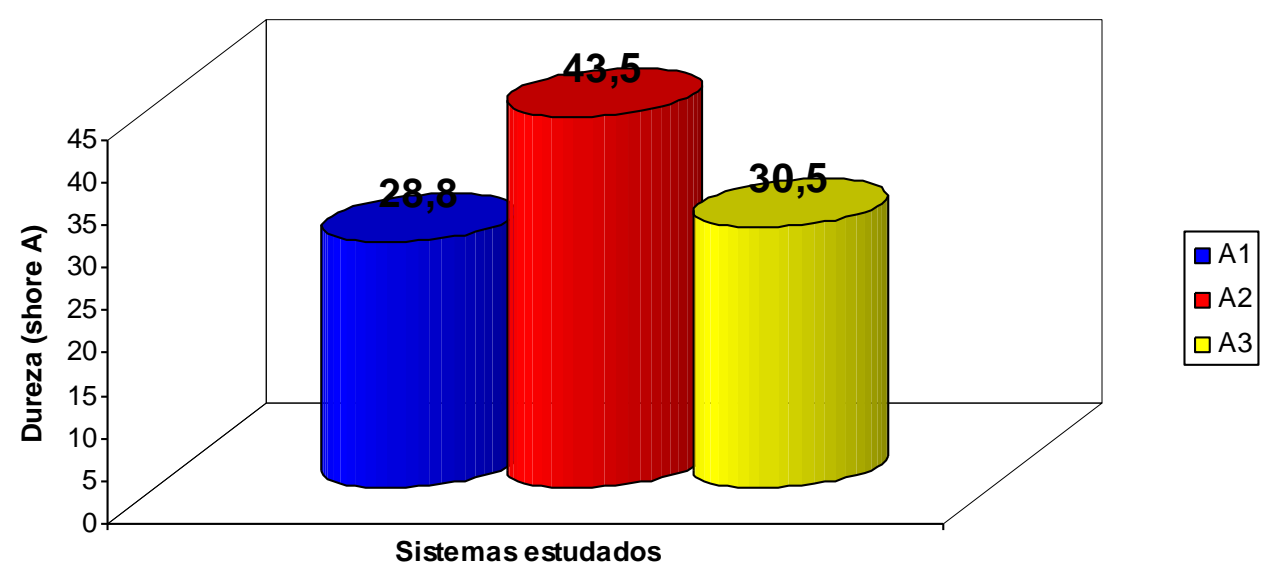

(b)

Figura 103: Dureza dos sistemas estudados. (a) Resultados das amostras estudadas ; (b) Resultados obtidos por Arroyo, (2003).

Analisando a figura 103 (a) verificou-se que a amostra F20 apresentou maior valor de resistência a penetração, ou seja, apresentou maior dureza (Shore A). 
Percebemos ainda a existência de variações entre os valores apresentados pelos materiais com carga e sem carga. A amostra F1, por se tratar de um material que não apresenta carga, possui uma dureza inferior aos demais sistemas, evidenciando, portanto, como comentado anteriormente, que as cargas atuam como reforço, fazendo com que o material resista à penetração.

Para as amostras que utilizaram como carga argilas organofílicas, também percebeu-se novamente a existência de uma influência no tratamento da argila organofílica, pois as amostras F19 e F20 (por se tratarem de amostras que possuem em suas composições um percentual de argila organofílica preparada em laboratório) apresentaram maiores valores de dureza, na faixa de 50 e 52 respectivamente. Esse resultado está de acordo com os resultados mostrados pelos ensaios de resistência à tração e alongamento na ruptura, pois como esses materiais apresentaram maiores valores para a resistência à tração e menores alongamentos na ruptura, isso evidencia que provavelmente sua dureza será elevada devido ao fato do material conter partículas de silicatos como cargas, o que favorecem interações com a borracha. Então, basicamente pôde-se observar que dois fatores influenciam significativamente nas propriedades mecânicas em nanocompósitos argila/borracha: a dispersão da argila no polímero e interação entre o polímero e as camadas da argila, pois quanto melhor for a dispersão da argila no polímero e mais forte for a interação entre o polímero e as camadas da argila, maiores os valores de suas propriedades mecânicas serão alcançadas.

Quanto à amostra F22, que é uma amostra carregada com negro de fumo, pelas mesmas razões explicadas anteriormente, essa amostra F22 apresentou um valor superior a amostra F1. A pequena diferença de seu valor quando comparada com as amostras que continham argilas organofílicas como carga (F19, F20 e F21) também se deve ao fato das diferenças morfológicas discutidas anteriormente quando comentou-se sobre a propriedade de alongamento na ruptura.

Com relação aos resultados de dureza obtidos nessa pesquisa, verificou-se que quando comparados com os resultados obtidos por Arroyo (2003), os mesmos encontraram-se coerentes com os reportados pelo mesmo, pois as amostras sem cargas apresentaram valores de dureza inferiores as demais amostras. Observou-se ainda que houve um aumento da dureza quando carregado com o negro de fumo, mas, quando carregadas com argilas organofílicas há um aumento significativo dessa propriedade. 
A figura 104 (a) e (b) ilustra o comportamento dos sistemas estudados com relação à densidade.

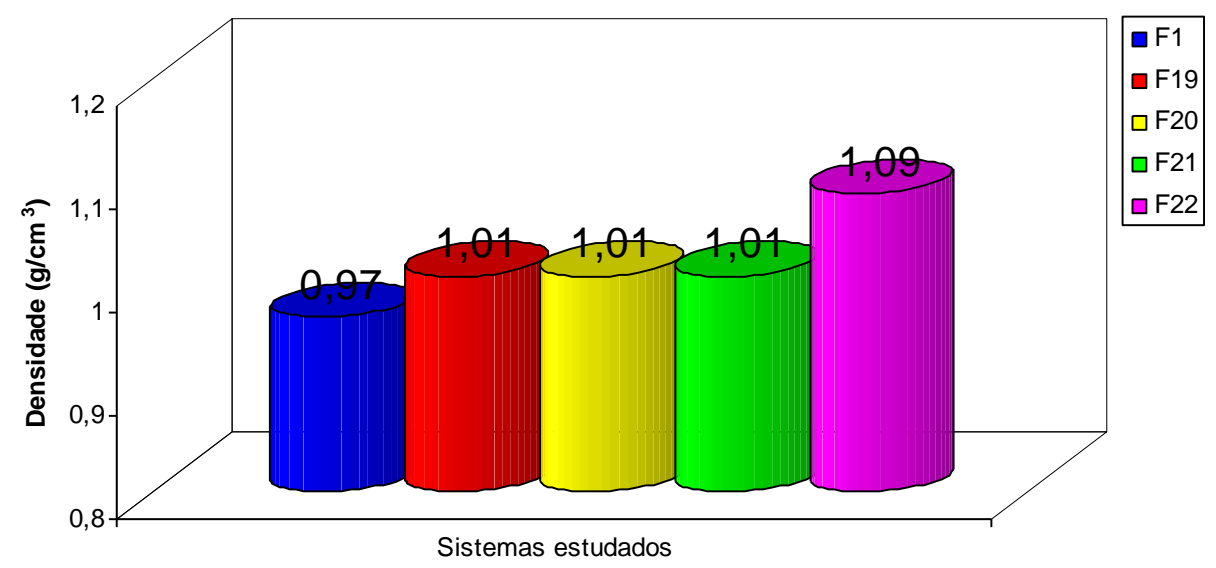

(a)

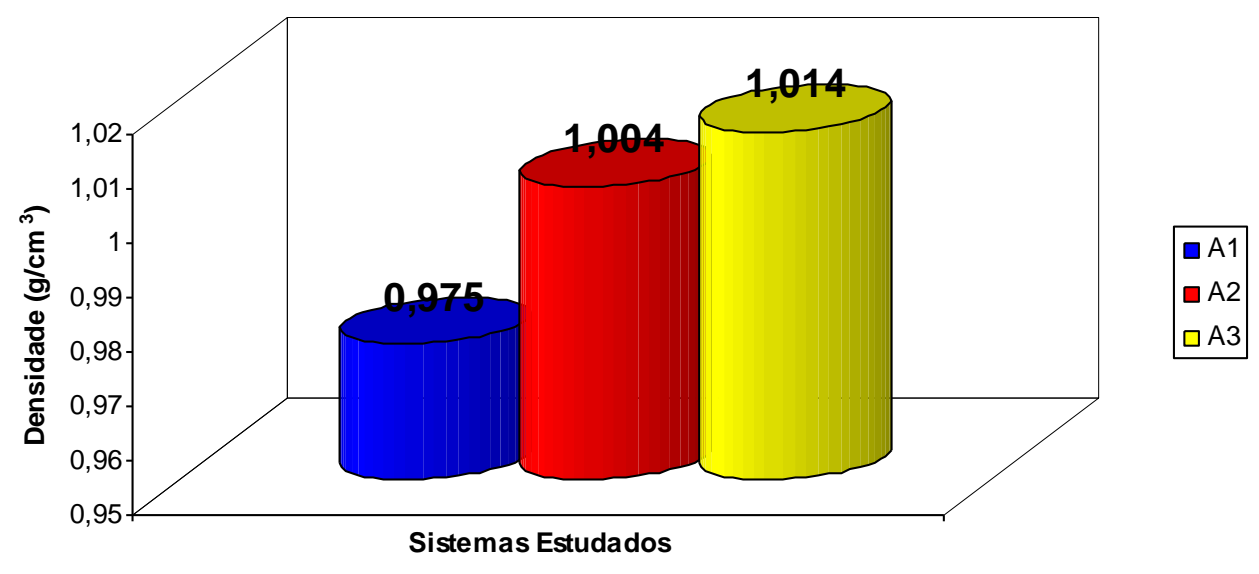

(b)

Figura 104: Densidade dos sistemas estudados. (a) Resultados das amostras estudadas; (b) Resultados obtidos por Arroyo, (2003).

Observando os valores de densidade apresentados na Figura 104 (a) verificou-se que a amostra F1 apresentou um valor inferior $\left(0,97 \mathrm{~g} / \mathrm{cm}^{3}\right)$ aos demais sistemas, devido ao fato da mesma se tratar de uma amostra de borracha pura, ou seja, sem cargas incorporadas a sua estrutura. 
Entre as amostras F19, F20, F21 percebeu-se não ter havido alteração de valor na sua densidade, pois ficaram na faixa de $1,01 \mathrm{~g} / \mathrm{cm}^{3}$. Esse fato pode ser explicado se levarmos em consideração que apesar das amostras terem passado por tratamentos de organofilização diferentes, mas as matérias-primas utilizadas para preparação das mesmas não mudou, ou seja, todas essas argilas são do grupo das esmectitas, logo é de se esperar que as mesmas não apresentassem muitas discrepâncias nos seus valores de densidade.

Para os resultados de densidade obtidos nessa pesquisa, verificou-se que quando comparados com os valores obtidos por Arroyo (2003), haver uma semelhança nos valores reportados pelo mesmo, ou seja, materiais sem cargas apresentaram valores de densidade inferiores aos materiais que utilizaram como cargas com o negro de fumo ou argilas organofílicas.

Por fim, fazendo uma analise comparativa conjunta de todas as propriedades mecânicas para as amostras com carga F19, F20, F21 e F22 com a F1 sem carga, observou-se que todas as amostras que possuíam argilas organofílicas como cargas (F19, F20, F21) apresentaram um desempenho de suas propriedades mecânicas superiores as amostras carregadas com a mesma quantidade (10pcr) de negro de fumo (F22) e a amostra sem carga (F1).

Esses resultados confirmaram o que já foi descrito por Arroyo (2003), ou seja, materiais que continham argilas organofílicas como cargas exibiram melhores propriedades mecânicas quando comparados aos com cargas convencionais (negro de fumo).

Outro fato que deve-se ressaltar é a possibilidade de termos obtido nanocompósitos argila organofílica/borracha, devido a essas melhorias expressivas verificadas em suas propriedades mecânicas. Porém, para confirmação desse fato faz-se necessário a realização de uma caracterização microestrutural, envolvendo principalmente as técnicas de DRX e MET (razões já discutidas e justificadas anteriormente).

\subsubsection{Difração de Raios X (DRX)}

Uma das técnicas indicadas para identificar a formação de um nanocompósito é a difração de raios $X(D R X)$. 
A figura 105 apresenta as curvas de raios $X$ dos sistemas: borracha pura (F1), argila organofílica/borracha (F19, F20 e F21) e negro de fumo/borracha (F22).

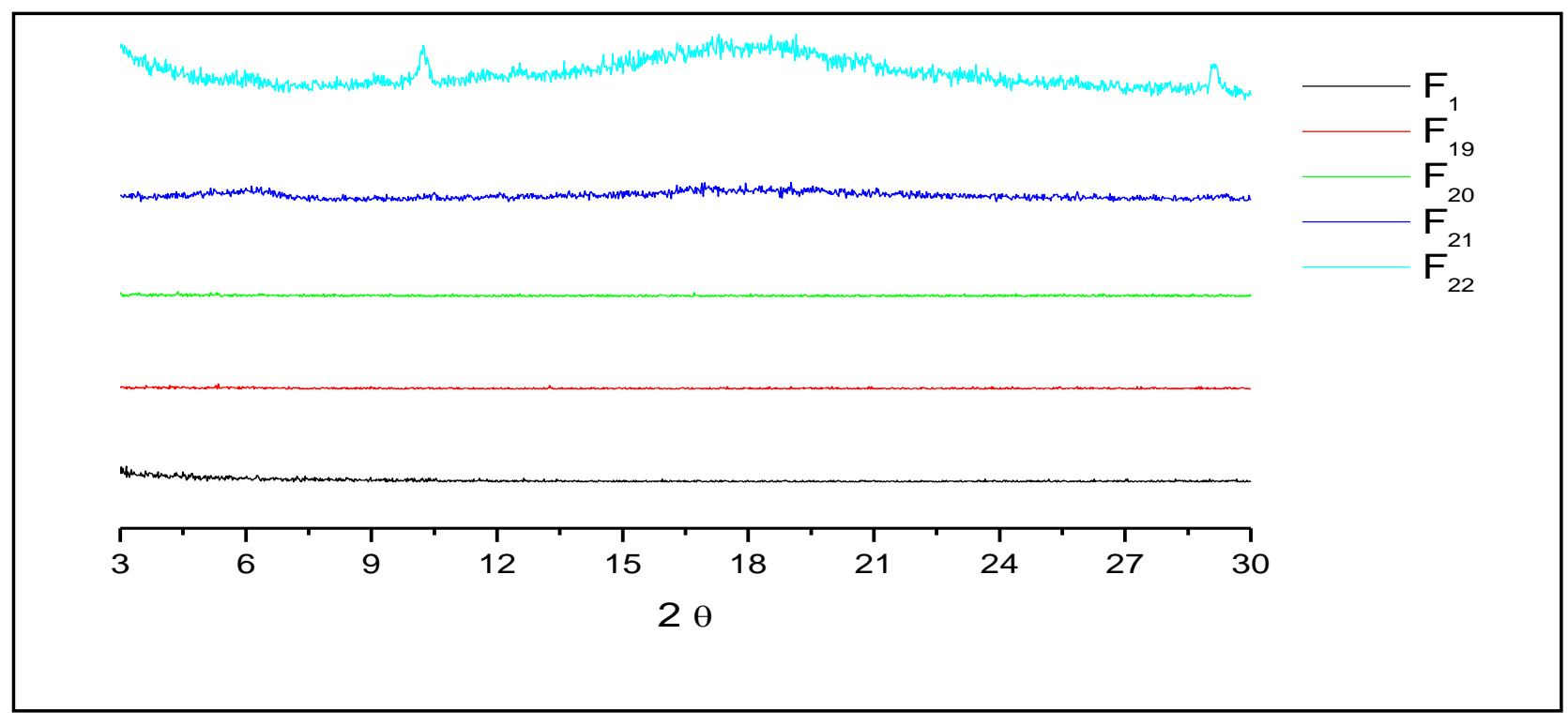

Figura 105: Curvas de raios $X$ dos sistemas estudados (intervalo $2 \theta$ entre 3 e $30^{\circ}$ ).

Analisando as curvas de raios $\mathrm{X}$ acima, observou-se que para todos os sistemas estudados, não há a reflexão basal referente ao plano $\mathrm{d}_{001}$. Com relação ao sistema F1, pode-se afirmar que este fenômeno ocorre devido ao fato deste sistema ser composto apenas de "borracha pura" e sendo este um polímero (amorfo), logo, não deve apresentar a reflexão basal referente ao plano $d_{001}$ e não havendo, portanto, o aparecimento de nenhum pico.

Para o sistema F22 (negro de fumo/borracha), a falta da reflexão basal do plano $d_{001}$ já era esperado. E deve-se ao fato deste ser comprovadamente um compósito já bastante estudado pela literatura (RAY \& OKAMOTO, 2003). Essa amostra foi utilizada como material de referência para se efetuar comparação de propriedades mecânicas nesta pesquisa.

Quanto aos sistemas F19, F20 e F21 (argila organofílica/borracha $\mathrm{CBO} /$ borracha, FGO/borracha e C30B/borracha - respectivamente) pôde-se observar que estes sistemas também não apresentaram nenhuma reflexão basal do plano $d_{001}$ (o que antes ocorria nas respectivas argilas organofílicas antes de serem incorporadas à borracha), sendo, portanto, uma forte evidência de que esses 
materiais tratam-se realmente de nanocompósitos do tipo parcialmente esfoliado ou delaminado. O não aparecimento de picos significa que as camadas lamelares estão completamente e uniformemente dispersas com o polímero intercalado de uma forma desordenada entre as camadas, comprovando que provavelmente o objetivo principal deste estudo, foi atingido, ou seja, foi possível a obtenção de nanocompósitos argilas organofílicas/borracha.

Visando ainda comprovar a ausência da reflexão basal do plano $\mathrm{d}_{001}$, que poderia ter se apresentado em pequenas intensidades e em ângulos menores do que o de costume e por isso estarem "mascarados" na Figura 105 pelo intervalo relativamente grande o ângulo $2 \theta$, decidiu-se fazer uma ampliação do referido intervalo, para investigar o aparecimento de prováveis picos referentes ao plano $\mathrm{d}_{001}$.

A figura 106 apresenta as curvas de raios $X$ dos sistemas estudados em um intervalo menor para o ângulo $2 \theta$.

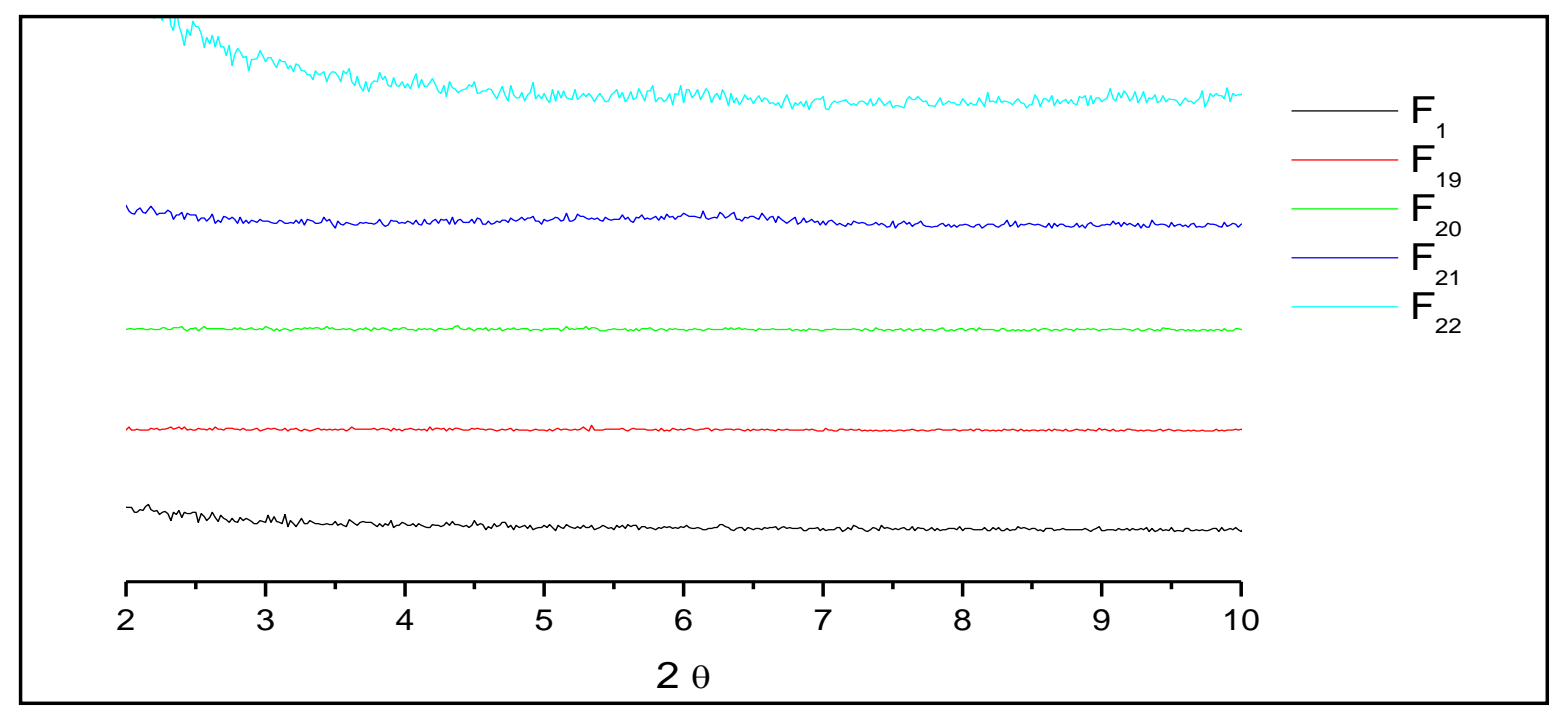

Figura 106: Curvas de raios $X$ dos sistemas estudados (intervalo do ângulo $2 \theta$ entre 2 e $\left.10^{\circ}\right)$

Então, analisando a figura 106, comprovou-se que realmente não houve reflexão basal do plano $\mathrm{d}_{001}$, para nenhuma das amostras estudadas, o que evidenciou a obtenção de nanocompósitos. Quanto da classificação pode-se observar que por ter havido um desaparecimento da reflexão basal $d_{001}$ deve ter ocorrido devido extensiva separação interlamelar associada com a delaminação das 
camadas do aluminossilicato na matriz polimérica, assim temos uma forte evidência que obtivemos um nanocompósito do tipo esfoliado ou parcialmente esfoliado. Esse fato ainda pode ser melhor comprovado quando associado ao intenso ganho nas propriedades mecânicas dos sistemas de argila organofílica/borracha estudados (F19, F20 e F21), quando comparados com o compósito negro de fumo/borracha (F22).

\subsubsection{CONCLUSÕES OBTIDAS}

Com base nos resultados apresentados nesta aplicação, chegou-se às seguintes conclusões:

\section{PARA AS MATÉRIAS-PRIMAS}

- As argilas Chocobofe não modificada (CB) e Fluid Gel comercial sódica (FG) apresentaram, após caracterização, resultados típicos de bentonitas oriundas do município de Boa Vista, Paraíba.

\section{PARA AS ARGILAS ORGANOFÍLICAS}

- Os resultados de DRX indicaram que para as amostras organofilizadas em laboratório (CBO e FGO), houve um aumento nas distâncias basais do argilomineral, o que evidenciou a intercalação do cátion orgânico.

- Os espectros de infravermelho para as argilas organofílicas sintetizadas em laboratório e industrialmente, evidenciaram a intercalação dos cátions quaternários de amônio, verificada a partir da presença de bandas características dos sais.

- A curvas de análises térmicas (ATD e TG) mostraram que houve um aumento na perda de massa quando incorporado o sal quaternário de amônio nas amostras.

- As micrografias eletrônicas de varredura revelaram uma morfologia com estruturas abertas (menos compacta). 
- Pela a análise de EDS verificou-se a presença de elementos característicos da composição de argilas esmectíticas da Paraíba, além da presença do $\mathrm{Cl}$ e C o que evidenciou a intercalação dos cátions quaternários de amônio nos argilominerais componentes das argilas estudadas.

\section{PARA OS NANOCOMPÓSITOS}

- O tipo de bentonita afeta as propriedades mecânicas dos sistemas argila organofílica/borracha.

- Das 23 formulações estudadas, aquelas que originaram materiais com melhores propriedades mecânicas foram as geradas com 10pcr de carga em 100pcr de borracha ( F19,F20,F21 e F22).

- Observou-se que as amostras que utilizaram argilas organofílicas como cargas apresentaram melhor desempenho de suas propriedades mecânicas quando comparadas às amostras com o mesmo teor de negro de fumo.

- Os resultados de DRX indicaram que os sistemas argila organofílica/borracha natural, provavelmente são estruturas de nanocompósitos parcialmente esfoliados.

Resumidamente, conclui-se que, foi possível desenvolver com êxito nanocompósitos argila organofílica/borracha natural e que assim como Arroyo (2003), os nanocompósitos obtidos nessa pesquisa apresentaram notáveis melhorias nas propriedades mecânicas quando comparados com a borracha carregada com a mesma quantidade de negro de fumo. 


\subsection{APLICAÇÃO 4:CARACTERIZAÇÃO DE BENTONITAS MODIFICADAS COM ÁCIDO E COM AGENTE PILARIZANTE VISANDO SUA UTILIZAÇÃO COMO CATALISADORES}

Devido a grande preocupação com o custo associado à desativação indesejável de catalisadores, houve um crescimento em pesquisas na área de catálise, visando investigar o comportamento dos catalisadores em diferentes reações catalíticas.

Argilas esmectíticas, constituídas pela família 2:1, ou seja, por duas folhas de silicato tetraédricos, com uma folha central octaédrica, unidas entre si por oxigênio comuns às folhas. São também conhecidas como montmorilonitas e bentonitas, materiais interessantes para as indústrias, porque são encontrados em abundância na natureza e, portanto, têm um baixo custo. Quando ativadas com ácidos fortes apresentam uso industrial como descorantes de óleos vegetais, animais e minerais, sendo também utilizadas como constituintes de catalisadores a base de zeólitas para o craqueamento.

Argilas pilarizadas são aquelas na qual foram introduzidos entre suas camadas elementares grandes cátions estáveis termicamente, através de uma troca iônica com os cátions interlamelares naturais da argila. Esses grandes cátions formam verdadeiros pilares que mantém as camadas separadas a uma distancia $\mathrm{D}_{001}$ (distância interplanar basal).

Tendo em vista as considerações anteriores, o presente trabalho propõe estudar a caracterização de bentonitas tratadas químicamente (natural, tratadas com ácido clorídrico e com agente pilarizante).

\subsubsection{OBJETIVO DESSE ESTUDO}

O objetivo para realização desse trabalho foi efetuar um tratamento da bentonita Sortida visando verificar através da sua caraterização o potencial de uso da mesma como catalisador. 


\subsubsection{MATERIAIS UTILIZADOS}

Neste trabalho, foram utilizados os seguintes materiais:

- Bentonita Sortida natural (oriunda do município de Boa Vista, Paraíba);

- Bentonita Sortida tratada com $\mathrm{HCl}$ com as seguintes concentrações $0,5 \mathrm{M} ; 1,0 \mathrm{M} ; 1,5 \mathrm{M}$ e 3,0 M;

- Bentonita Sortida pilarizada (sintetizada no laboratório da UFCG) .

\subsubsection{METODOLOGIA UTILIZADA}

A metodologia está dividida em 3 partes :

- PARTE I - Tratamento Ácido: Processo de tratamento ácido das bentonitas Sortidas utilizando várias concentrações da solução de $\mathrm{HCl}$;

- PARTE II - Pilarização: Processo de pilarização das bentonitas Sortidas ;

- PARTE III - Métodos de Ensaios de Caracterização: Caracterização desses materiais.

\subsubsection{Parte I - Tratamento Ácido}

Foram utilizadas amostras de bentonitas Sortidas (BS) natural, provenientes do município de Boa Vista- PB. Para o tratamento químico, as referidas argilas foram tratadas com ácido clorídrico, utilizando concentrações diferentes: 0,5 M, 1,0 M ; 1,5 $\mathrm{M}$ e 3,0 M . Foi adicionada cada solução à argila e a suspensão foi mantida, sob agitação, por 30 minutos à temperatura de $70^{\circ} \mathrm{C}$. Filtrou-se em funil de Buckner sob vácuo, sendo o pó lavado com água deionizada até que o pH ficasse próximo de 7; por fim, o pó obtido foi secado em estufa e passado em peneira ABNT \# 200 (figura 107). 


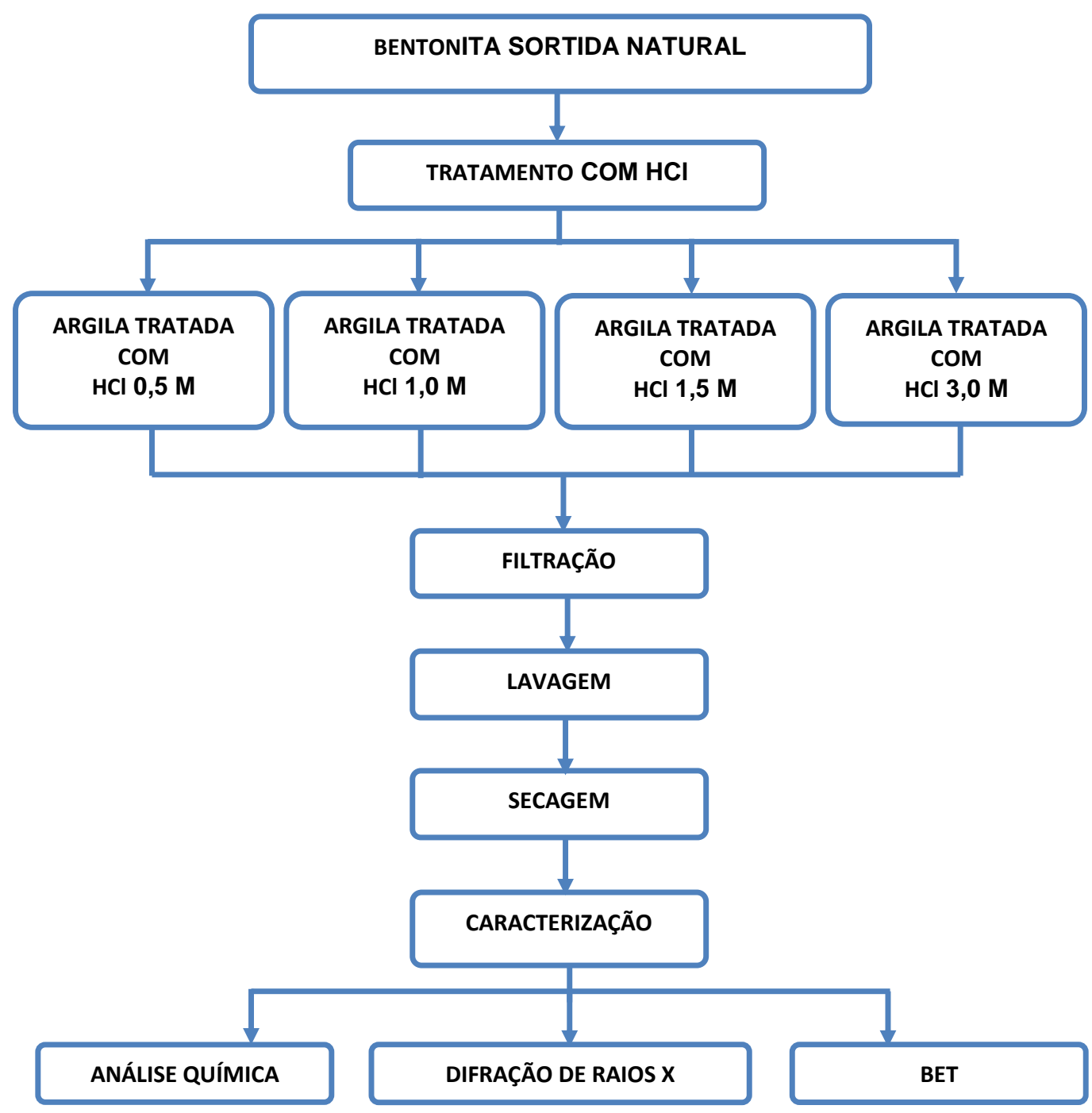

Figura 107: Esquema ilustrativo da metodologia utilizada para o tratamento ácido com $\mathrm{HCl}$.

\subsubsection{Parte II - Pilarização}

A metodologia empregada para a pilarização da bentonita Sortida chocolate está ilustrada por fluxograma, através da figura 108 a seguir: 


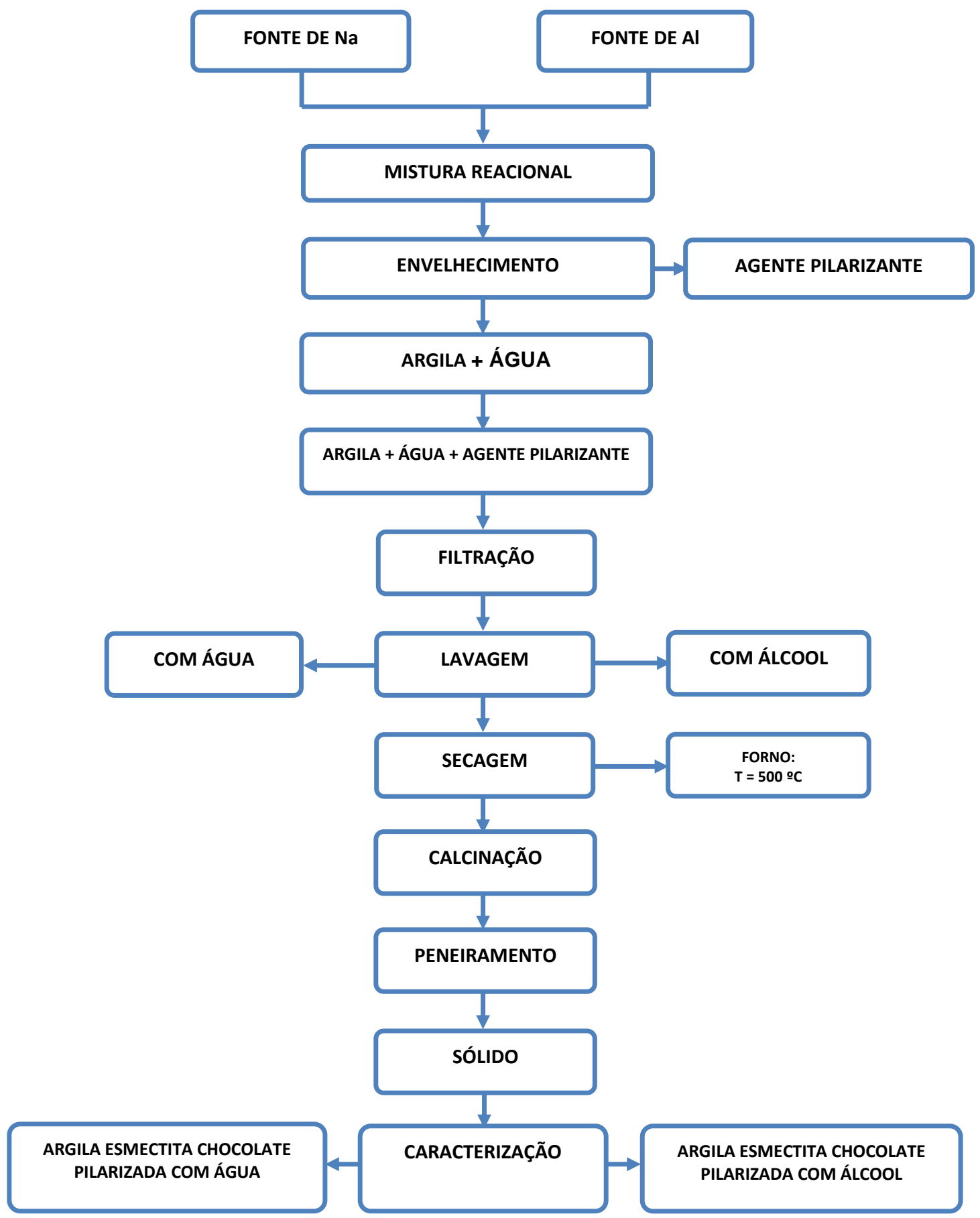

Figura 108: Esquema ilustrativo da metodologia utilizada para a pilarização da bentonita Sortida. 


\subsubsection{Parte III - Métodos de Ensaios de Caracterização}

Para caracterização das amostras utilizou-se os seguintes métodos de ensaios: Fluorescência de raios $\mathrm{X}$; Difração de raios $\mathrm{X}$; Análises Térmicas; Microscopia Eletrônica de Varredura; Análise textural - Método de BET.

\subsubsection{RESULTADOS OBTIDOS}

\subsubsection{Parte I - Tratamento Ácido}

Visando estudar o efeito da concentração do ácido clorídrico $(\mathrm{HCl})$ na estrutura da bentonita Sortida de Boa-Vista-PB, realizou-se algumas caracterizações, dentre elas, Fluorescência de raios $X$, Difração de raios $X$ e Análise Termogravimétrica e Termodiferencial.

\subsection{Fluorescência de raios $X$}

A análise por Fluorescência de raios $X$ foi empregada para se determinar a composição química da bentonita Sortida antes e após o tratamento com o ácido clorídrico ( $\mathrm{HCl}$ ). A tabela 41 mostra os resultados de análise química:

Tabela 41: Resultados das análises químicas. Composição química da argila antes e após o tratamento com solução de ácido clorídrico $(3,0 \mathrm{M})$.

\begin{tabular}{c|cc|}
\hline $\begin{array}{c}\text { Porcentagem de } \\
\text { Massa }\end{array}$ & Argila Natural & Argila Tratada com HCl (3M) \\
\hline $\mathrm{SiO}_{2}$ & 59,60 & 67,69 \\
$\mathrm{Al}_{2} \mathrm{O}_{3}$ & 14,50 & 14,45 \\
$\mathrm{Fe}_{2} \mathrm{O}_{3}$ & 10,41 & 6,69 \\
$\mathrm{CaO}$ & 1,27 & 0,10 \\
$\mathrm{Na}_{2} \mathrm{O}$ & 0,26 & 0,52 \\
$\mathrm{~K} \mathrm{O}$ & 0,32 & 0,19 \\
$\mathrm{MnO}$ & - & - \\
$\mathrm{MgO}$ & 2,93 & 1,84 \\
$\mathrm{P}_{2} \mathrm{O}_{5}$ & - & - \\
$\mathrm{TiO}_{2}$ & - & - \\
\hline
\end{tabular}


Observa-se que o teor de óxido de silício $\left(\mathrm{SiO}_{2}\right)$ aumentou com o tratamento ácido. Tem-se que o alto teor de $\mathrm{SiO}_{2}$ caracteriza a argila em estudo como sendo tipicamente bentonita. O teor de óxido de magnésio $(\mathrm{MgO})$ diminuiu com o tratamento ácido, porém, apresenta-se ainda de forma apreciável, caracterizando a argila em estudo como sendo bentonita. $\mathrm{O}$ teor de $\mathrm{Fe}_{2} \mathrm{O}_{3}$ (óxido de ferro III) diminuiu com o tratamento ácido, acontecendo o mesmo com $\circ \mathrm{Al}_{2} \mathrm{O}_{3}$ (óxido de alumínio III). $\mathrm{O} \mathrm{Fe}^{3+}$ e $\circ \mathrm{Si}^{4+}$ podem substituir isomorficamente o $\mathrm{Al}^{3+}$, causando com isso, possíveis mudanças catalíticas na amostra. Houve uma diminuição brusca no teor de $\mathrm{CaO}$ (óxido de cálcio), e uma pequena diminuição do teor de $\mathrm{Na}_{2} \mathrm{O}$ (óxido de sódio). $\mathrm{O} \mathrm{Na}^{+}$substitui o $\mathrm{Ca}^{2+}$ até proporções mínimas, o que justifica a diminuição brusca do teor de $\mathrm{CaO}$. O teor de $\mathrm{K}_{2} \mathrm{O}$ (óxido de potássio) diminuiu com o tratamento ácido. A quantidade de tal óxido nas argilas é geralmente maior do que a quantidade de $\mathrm{Na}_{2} \mathrm{O}$. O teor de $\mathrm{TiO}_{2}$ (óxido de titânio) aumentou um pouco com o tratamento ácido. Teores abaixo de $1 \%$ deste óxido na composição da argila não provocam mudanças nas propriedades tecnológicas das argilas.

\subsection{Difração de raios $X$}

Os resultados obtidos das amostras quando submetidos à Difração de raios $X$ estão apresentados na figura 109 (a,b).

Ao observar as curvas de raios $X$ da figura 109 é possível verificar que as amostras de bentonitas Sortida: (a) natural, é formada por uma mistura de argilomineral montmorilonita, caulinita e quartzo, enquanto que a amostra tratada com ácido clorídrico (3,0 M) ilustrado na (b), é composta apenas pela caulinita e quartzo.

Do ponto de vista estrutural, o material sofreu alterações após o tratamento químico. Ao comparar as bentonitas Sortida natural e tratada com $\mathrm{HCl}(1,5 \mathrm{M})$ foi observado, sobretudo, uma diminuição da intensidade do pico característico da montmorilonita. Ao analisar a figura 109 (b) bentonita tratada com $\mathrm{HCl}(3,0 \mathrm{M})$ é possível verificar a total destruição da estrutura da montmorilonita através do desaparecimento do pico característico da mesma. Este comportamento pode ser explicado através das condições muito severas da ativação ácida. 


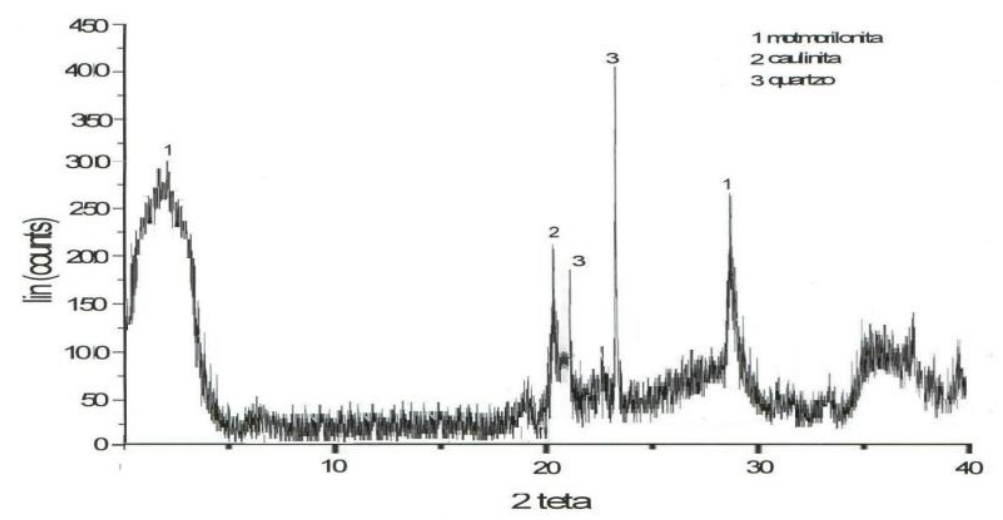

(a)

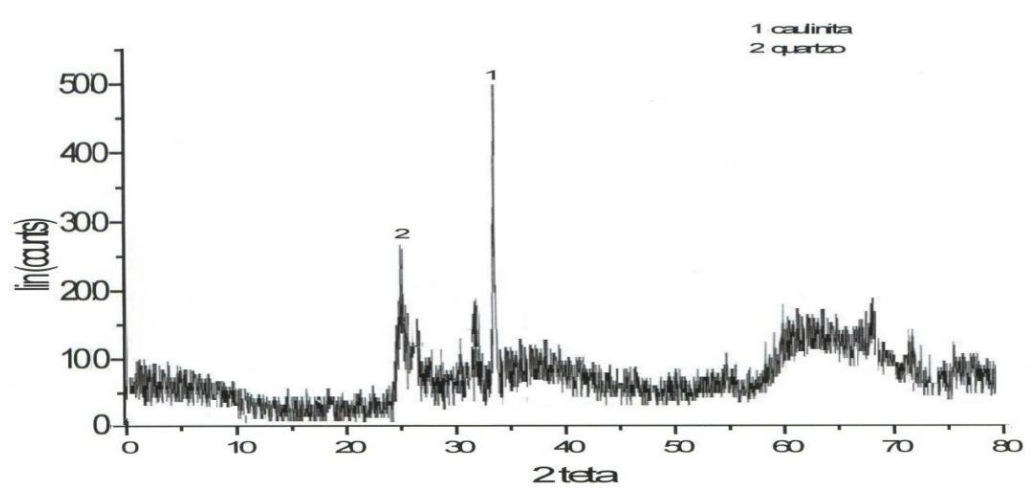

(b)

Figura 109: Curvas de raios $X$ da bentonita Sortida (a) natural (b) tratada com $\mathrm{HCl}(3,0 \mathrm{M})$.

\subsection{Análises Térmica Diferencial e Termogravimétrica}

A análise térmica diferencial da bentonita Sortida natural (figura 110) apresenta um perfil de curva característico das argilas contendo argilominerais do grupo montmorilonitas. Pode-se observar uma perda de massa de $11 \%$. A 176C há um pico endotérmico de perda de água adsorvida. A $584^{\circ} \mathrm{C}$ existe um pico endotérmico, sendo descrito pela baixa intensidade, caracterizando a desidroxilação da amostra rica em ferro, concordando com os resultados da análise química. Acima de $800^{\circ} \mathrm{C}$, há um pico duplo, endo-exotérmico, cujos máximos estão a $846^{\circ} \mathrm{C}$ e $867^{\circ} \mathrm{C}$, respectivamente. O primeiro é o da destruição parcial do reticulado cristalino e o pico exotérmico é pouco ativo e foi encontrado a uma temperatura de $867^{\circ} \mathrm{C}$ em função da nucleação da mulita, sua intensidade acentuada em relação à curva 
característica da montmorilonita se deve a presença de uma quantidade de caulinita, como apresentado nas curvas de raios $\mathrm{X}$.

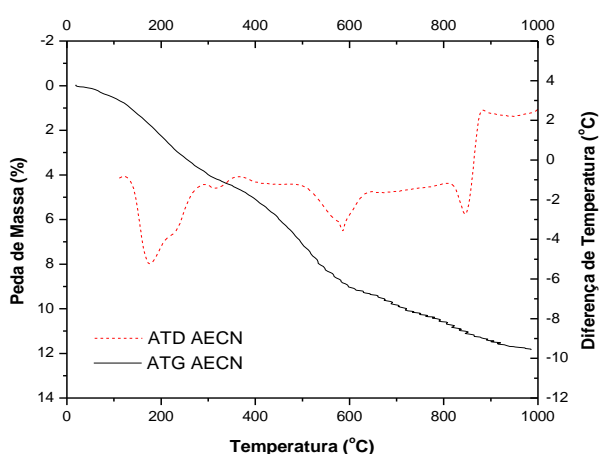

(a)

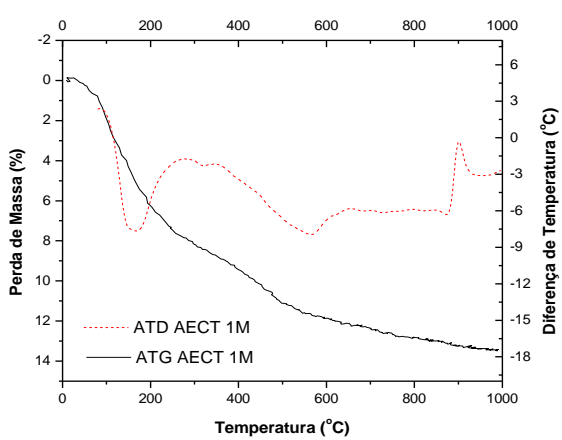

(c)

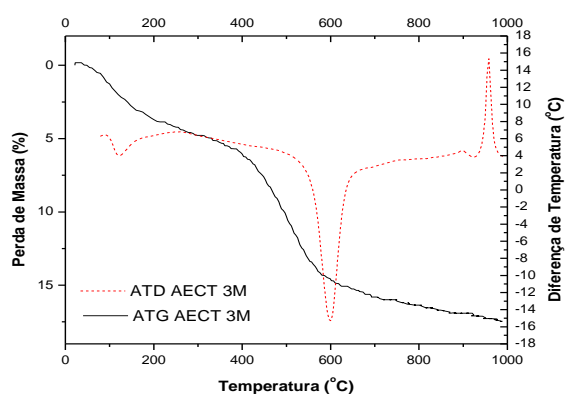

(e)

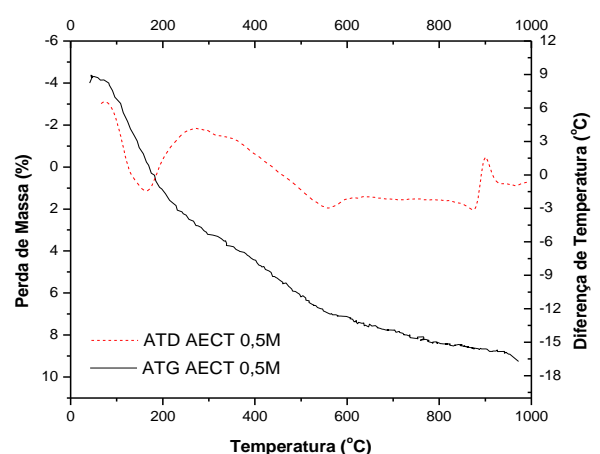

(b)

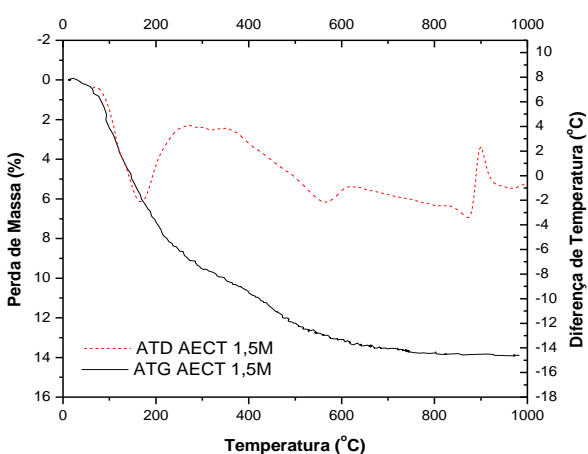

(d)

Figura 110: Perfis de ATG/ATD para bentonita Sortida natural, tratada com ácido clorídrico (0,5M; 1,0M;1,5M e 3,0 M).

A bentonita Sortida tratada com solução de ácido clorídrico $(0,5 \mathrm{M})$ é semelhante à natural. Verifica-se uma perda de massa de $13 \%$. Na figura 110 foi possível constatar que a bentonita Sortida tratada com solução de ácido clorídrico $(3,0 \mathrm{M})$ um pico endotérmico $\left(176^{\circ} \mathrm{C}\right)$, o qual é menos intenso, e o pico endotérmico $\left(600^{\circ} \mathrm{C}\right.$ ) e exotérmico (superior a $867^{\circ} \mathrm{C}$ ) são bem mais intensos, concordando com 
os resultados de difração de raios $\mathrm{X}$, onde é possível verificar o desaparecimento da montmorilonita e uma maior intensidade da caulinita.

\subsubsection{Parte II - Pilarização}

\subsection{Caracterização Textural - Método de BET}

A acessibilidade da superfície catalítica aos reagentes gasosos é de importância considerável na seleção dos materiais sólidos que tem que funcionar como catalisadores para reações heterogêneas. A medida da área da superfície é extremamente importante na predição do desempenho do catalisador na reação heterogênea gasosa (CIOLA, 1981).

O fundamento do método consiste na adsorção física de moléculas gasosas pela superfície de um determinado sólido, onde é escolhido um gás cujas moléculas são suficientemente pequenas para penetrar nos poros do sólido. O nitrogênio é usado justamente por que ele pode ser fisissorvido em praticamente toda a superfície do catalisador.

Através da análise da tabela 42 e das isotermas de adsorção figura 111, observa-se um aumento na área específica com relação à argila natural, tanto da argila pilarizada com lavagem adicional de álcool, quanto da argila pilarizada com lavagem adicional de água, confirmando análises anteriores que ao tratar a argila natural com a solução oligomérica, ocorre uma incorporação de Al e um aumento no espaçamento basal.

Tabela 42: Área específica dos materiais naturais antes e após a pilarização.

\begin{tabular}{ll} 
& \multicolumn{1}{c}{$\begin{array}{c}\text { AREA ESPECIFICA } \\
\left(\mathrm{m}^{2} / \mathrm{g}\right)\end{array}$} \\
\hline AECN & 116,6769 \\
AECPAL & $\mathbf{1 2 0}, \mathbf{4 4 4 2}$ \\
AECPAG & $\mathbf{1 2 1 , 0 0 0 3 3}$ \\
\hline
\end{tabular}




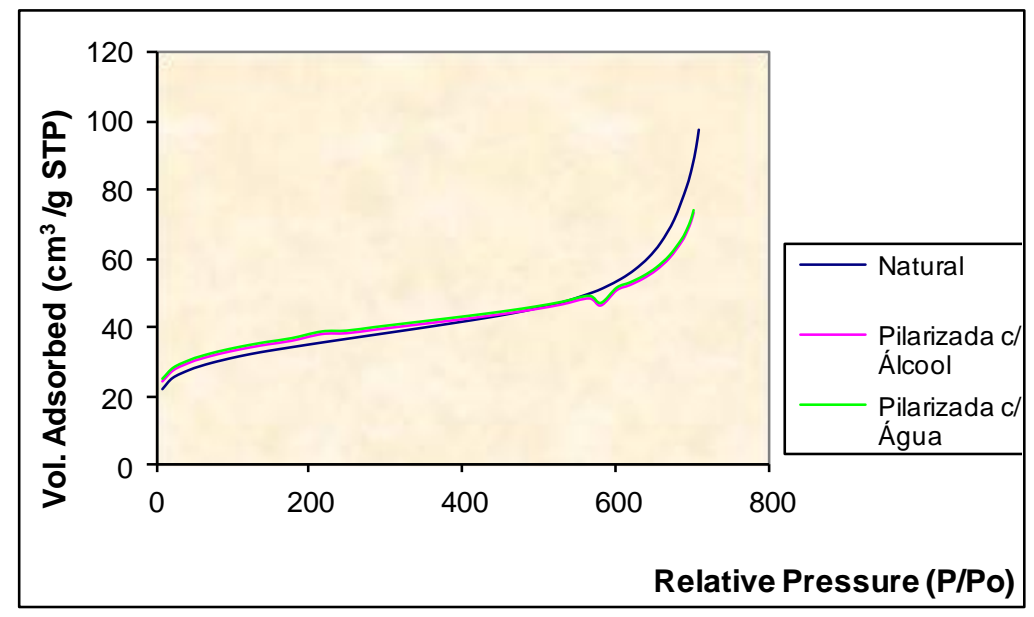

Figura 111: Isotermas Adsorção Física de Nitrogênio.

$\mathrm{Na}$ figura 111 apresentam-se as isotermas de adsorção de $\mathrm{N}_{2}$ a $196^{\circ} \mathrm{C}$, sobre as amostras: natural e pilarizadas, determinadas através das medidas de capacidade de adsorção.

As isotermas de adsorção para as amostras naturais e pilarizadas pertencem, segundo a classificação de BET, ao tipo III e são características da adsorção em multicamadas. Podem ocorrer em sólidos não porosos (neste caso, a adsorção ocorre na superfície externa das partículas do material), em sólidos macroporosos ou ainda em materiais com mesoporos de geometria tal que a condensação só pode ocorrer à pressão de situação.

Em trabalhos futuros, pretende-se testar esses materiais argilosos na reação catalítica de craqueamento de n-heptano, visando comprovar a eficiência destes como catalisadores.

\subsubsection{CONCLUSÕES OBTIDAS}

Com relação ao estudo do efeito da concentração do ácido clorídrico $(\mathrm{HCl})$ na estrutura da bentonita Sortida de Boa-Vista-PB, permitiu chegar as seguintes conclusões: 
- A concentração do ácido clorídrico usada (0,5 M a 3,0 M) constitui uma variável operatória importante;

- A partir da análise química foi possível verificar uma extração do teor de ferro da bentonita Sortida com o tratamento com $\mathrm{HCl}(3,0 \mathrm{M})$;

- Do ponto de vista estrutural, após o tratamento químico, os resultados de difração de raios $\mathrm{X}$ demonstram que à medida que ocorre um aumento da concentração do ácido, o pico característico da montmorilonita tende a diminuir até desaparecer;

- Os resultados de análise térmica diferencial e termogravimétrica concordam com os resultados de difração de raios $\mathrm{X}$.

A respeito do estudo de pilarização pode-se concluir que:

- Houve um aumento da área específica após a pilarização;

- Através das medidas de capacidade de adsorção destes materiais obteve-se isotermas do tipo III, segundo a classificação de BET.

Em resumo, através das caracterizações destes materiais argilosos tratados quimicamente foi possível observar que houveram modificações estruturais que provavelmente potencializaram as capacidades catalíticas destas argilas. Porém, pretende-se através de trabalhos futuros realizar testes com esses materiais argilosos na reação catalítica de craqueamento de n-heptano, visando comprovação de sua eficiência como catalisadores em algumas reações. 
CAPÍTULO 6 CONCLUSÕES 


\section{CAPÍTULO 6- CONCLUSÕES}

Diante dos resultados obtidos pode-se concluir que:

\section{Para a caracterizacão físico-química e mineralógica:}

As argilas estudadas apresentaram, após caracterização físico-química e mineralógica, resultados típicos de bentonitas do município de Boa Vista-PB:

$\left.1^{\circ}\right)$ As curvas de difração de raios $X$ confirmam que as argilas Chocolate, Bofe, Chocobofe, Sortida e Verde Lodo são amostras de bentonitas com argilominerais do grupo da esmectita, provavelmente, montmoriloníticos e com presença do mineral quartzo. A amostra Verde-Lodo apresenta ainda a caulinita.

$\left.2^{\circ}\right)$ Analisando conjuntamente os resultados das curvas de análises termicas das bentonitas naturais foi possível verificar que os mesmos bastante semelhantes e que todas as amostras apresentaram um perfil de curva característico das argilas contendo argilominerais do grupo montmorilonitas

$3^{\circ}$ ) Através dos resultados das micrografias foi possível verificar que as partículas lamelares encontram-se empilhadas e aglomeradas, formando aglomerados de morfologia irregular, com contornos bem definidos e com dimensões variáveis e maiores que $0,53 \mu \mathrm{m}$

$4^{\circ}$ ) Através da análise de EDS verificou-se que as todas as amostras de argila em estudo apresentam em sua composição basicamente Si e Al, característicos de bentonitas da Paraíba, traços de $\mathrm{Na}, \mathrm{Mg}$ e $\mathrm{Ca}$; apresentam também em sua composição o Fe.

$\left.5^{\circ}\right)$ Os espectros na região de infravermelho das amostras estudadas apresentaram espectros bastantes semelhantes, com bandas características da presença de hidroxilas, água adsorvida e de ligações Si-O-Si. Apresentando portanto espectros praticamente dentro da mesma faixa de comprimento de onda. Comparando-se os espectros das amostras, não foi percebida praticamente nenhuma alteração nas posições das bandas características das mesmas, já que todas tratam-se de amostras de bentonitas oriundas da Paraíba. 
6º) Através da análise textural (BET) foi possível observar e que as argilas que apresentaram uma maior área específica foram a Chocobofe, Sortida e da Bofe. Também percebeu-se que a argila Verde Lodo apresentou uma menor área específica. A mesma tendência da área superficial foi observada para o volume de poros e o diâmetro de poros

\section{Para as aplicacões e usos:}

Para os ensaios de aplicações realizados com as diversas amostras de argilas de Boa Vista-PB permitem as seguintes conclusões com relação aos usos da bentonitas:

1) Com relação ao Uso de Bentonitas para o tratamento de efluentes: Através da análise do teor de óleo/água verificou-se que as amostras apresentaram um comportamento similar, apresentando, um desempenho satisfatório de adsorção de óleo e comprovando a eficiência do processo de separação óleo/água, pois esses valores encontram-se de acordo com o exigido pelo CONAMA .Logo, as argilas organofílicas Chocolate (sal HDTMA-Cl com concentração $80 \mathrm{meq} / 100 \mathrm{~g}$ ), Fluid Gel (sal HDTMA-Cl com concentração $100 \mathrm{meq} / 100 \mathrm{~g}$ ) são materiais promissores para separação óleo/água.

$\left.2^{\circ}\right)$ Com relação ao Uso de Bentonitas como catalisadores para a produção de biodiesel: Uma avaliação dos resultados indica que é possível obter o biodiesel a partir de catalisadores argilosos, porém investigações adicionais sobre otimização das condições experimentais utilizando catalisadores heterogêneos são necessárias, tendo em vista a melhoria do processo de produção do biodiesel.

3) Com relação ao Uso de Bentonitas para nanocompósitos: conclui-se que, foi possível desenvolver com êxito nanocompósitos argila organofílica/borracha natural e que assim como Arroyo (2003), os nanocompósitos obtidos nessa pesquisa apresentaram notáveis melhorias nas propriedades mecânicas quando comparados com a borracha carregada com a mesma quantidade de negro de fumo.

$\left.4^{\circ}\right)$ Com relação ao Uso de Bentonitas modificadas com ácido e agente pilarizante visando sua utilização como catalisadores: A concentração do ácido clorídrico usada constitui uma variável operatória importante. Do ponto de vista estrutural, após o 
tratamento químico, os resultados de difração de raios $\mathrm{X}$ demonstram que a medida que ocorre um aumento da concentração do ácido o pico característico da montmorilonita tende a diminuir até desaparecer. Houve um aumento da área específica após a pilarização. Logo, os resultados indicaram que os tratamentos químicos realizados em argilas corroboraram para tornar possível o seu uso como catalisadores argilosos em diferentes reações catalíticas.

Tendo em vista os resultados relatados acima, pode ser concluído que as argilas de Boa Vista-PB ainda apresentam boas propriedades tecnológicas para diversos usos. E que passados 35 anos da tese do prof Dr. Pérsio de Souza Santos percebe-se que as bentonitas da Paraíba continuam sendo matérias- primas interessantes para as indústrias, pois pesquisas em todo país corroboram para o desenvolvimento de novas aplicações e usos destes materiais. 
CAPÍTULO 7- SUGESTÕES PARA TRABALHOS FUTUROS 


\section{CAPÍTULO 7- SUGESTÕES PARA TRABALHOS FUTUROS}

As sugestões estão descritas a seguir:

- Estudar o desempenho das variedades mineralógicas de outras jazidas de Boa Vista-PB;

- Aprofundar mais os estudos referentes às argilas da mina Lages, realizando mais ensaios de caracterização desses materiais (por exemplo: MET);

- Continuação de um estudo mais detalhado sobre os usos das argilas estudadas nessa tese;

- Estudo detalhado de caracterização mineralógica e física de bentonitas de outras regiões da Paraíba (por exemplo: Cubati e Pedra Lavrada);

- Realizar estudos econômicos para avaliar a viabilidade das bentonitas da Paraíba em aplicações tecnológicas diferenciadas; 
CAPÍTULO 8REFERÊNCIAS DA LITERATURA 


\section{CAPÍTULO 8- REFERÊNCIAS DA LITERATURA}

ABREU, S. F. Recursos minerais do Brasil, Ed. Edgard Blücher, $2^{\underline{a}}$ ed., V. 1, São Paulo-SP, 324p, 1973.

ALTHER, G. R. Using organoclays to enhance carbon filtration, Waste Management, 22 (5), 507-513, 2002.

AMORIM, L.V. Melhoria, proteção e recuperação da reologia de fluidos hidroargilosos para uso na perfuração de poços de petróleo. Tese (Doutorado) UFCG. Campina Grande-PB, 2003.

ARROYO, M., LÓPEZ-MACHADO, M. A., HERRERO, B. -Organo-montmorillonite as substitute of carbon black in natural rubber compounds, Polymer, 44, 2447-2453, 2003.

BAILEY,S.W, BRINDLEY,G.W.;JOHNS,W.D.;MARTIN,R.T,ROSS,M. Summary of national and international recommendations on clay mineral nomenclature, Clays and clay minerals $\mathrm{n}^{\circ}$ 19, 129,1971.

BARAÚNA, O. S. Argilas esmectíticas do Nordeste brasileiro. Anais do II Congresso Brasileiro de Engenharia de Minas, 2, 667-698, 1993.

BARRET, E. P.; JOIYNER, L.G.; HALENDA, P. P. The determination of pore volume and area distributions in porous substances. I Computations from nitrogen Isotherms, Journal of American Chemistry Society., v.73, p.373,1953.

BENTONIT, Disponível em: <http://www.trainweb.org/wyomingrails/ wymining/ wybentonite.html >. Acesso em: 10/01/2011.

BENTONIT UNIÃO NORDESTE S/A, Material explicativo fornecido pela empresa 2005.

BERTOLINO, L.C.; LUZ, A.B. da, TIMÓTEO, D.M.O., TONNESEN, D.A. PEÇANHA, E.R. Caracterização mineralógica e estudos de beneficiamento da bentonita de Pedra Lavrada-PB, II Simpósio de Minerais Industriais do Nordeste, 2010.

BERGAYA， F.; THENG,B.K.G.;LAGALY,G. Handbook of Clay Science. Developments in Clay Sciense, vol1. Elsevier Ltd. All rights reserved. 2006. 
BOREZEK, J. L.; HARRIS, W. G.; KIZZA, P. N. Clays and Clay Minerals, 50, 11, 2002.

BOTELHO,K.T. Synthesis and characterization of orgnophilic clay to use in polystyrene-clay nanocomposite. Program and proceedings the polymer processing society, 23 rd annual meeting, 2007.

BRUNAUER,S.; EMMETT, P. H.; TELLER, E. Adsorption of gases in multimolecular layers, Journal of the American Chemical society, v.60, p309, 1938.

CALDASSO, A. L. S. Jazida de Argila de Boa Vista - PB, Bol. Soc. Bras. Geol. 16(1), 1979.

CANDEIA, A. R. Biodiesel de soja: síntese, degradação e misturas binárias. Tese de doutorado, UFPB, João Pessoa-PB, 2008.

CAPONERO, J. Reciclagem de Pneus, Tese (Doutorado) apresentada ao Departamento de Engenharia Metalúrgica e de Materiais da Escola Politécnica da Universidade de São Paulo. São Paulo, 2002.

CIOLA, REMOLO - Fundamentos da Catálise, 1aㅡ Ed. Moderna, Ed. da Universidade de São Paulo- USP; 1981.

CHOY, J. H.; KWAK, S. Y.; HAN, Y. S.; KIM, B. W. New organo-montmorillonite complexes with hydrophobic and hydrophilic functions Materials Letters, 33, 143-147, 1997.

COELHO, M.J.; CABRAL JR.,M. Estudo prospectivo da bentonita: tendências de mercado. II Simpósio de Minerais Industriais do Nordeste, Campina Grande- PB, 2010.

CPRM, Serviço Geológico do Brasil. Diagnóstico do município de Boa Vista, 2005 (a).

CPRM, Serviço Geológico do Brasil. Diagnóstico do município de Cubati, 2005 (b).

CPRM, Serviço Geológico do Brasil. Diagnóstico do município de Pedra Lavrada 2005 (c). 
DNPM, Departamento Nacional de Produção Mineral. Anuário Mineral Brasileiro, Bentonita, 1973.

DNPM, Departamento Nacional de Produção Mineral. Anuário Mineral Brasileiro, Bentonita, 2006.

DNPM Departamento Nacional de Produção Mineral. Anuário Mineral Brasileiro, Bentonita, 2007.

DNPM, Departamento Nacional de Produção Mineral. Anuário Mineral Brasileiro, Bentonita,2008.

DNPM, Departamento Nacional de Produção Mineral. Anuário Mineral Brasileiro, Bentonita, 2009.

FAGUNDES, F. P. Influência das variações reacionais na obtenção do biodiesel de mamona e seu comportamento reológico em misturas binárias com o combustível diesel. Dissertação (Mestrado), Orientadora: Marta Costa, Natal - RN de agosto de 2006.

FERREIRA, H. C.; SILVA, A.R.V. Argilas bentoníticas: conceitos, estruturas, propriedades, usos industriais, reservas, produção e produtores/fornecedores nacionais e internacionais, REMAP v.3.2, 2008.

FERREIRA, H. C.; Obtenção de argilas organofílicas purificadas para uso em fluidos de perfuração base óleo. Dissertação (Mestrado) UFCG, Campina Grande-PB 2005.

FERRARI, R. A.; OLIVEIRA, V. S.; SCABIO, A. Biodiesel de soja - Taxa de conversão em ésteres etílicos, caracterização físico-química e consumo em gerador de energia, Química Nova, V. 28, 2005.

FREEDMAN, B.; PRYDE, E. H.; MOUNTS, T. L. Variable affecting the yields of fatty esters from transesterified vegetable oils. Journal of American Oil Chemical Society, v. 61, p. $1638-1643,1986$.

GALVÃO, L. P. F. C. Avaliação termoanalítica da eficiência de antioxidantes na estabilidade oxidativa do biodiesel de mamona. Dissertação (Mestrado), Orientador: Valter José Fernandes Júnior, Natal - RN, Novembro de 2007. 
GOPINATH, T.R., CRUZ, V.C.A., FREIRE, J.A. Estudo comparativo da composição química e as variedades de argilas bentoníticas da região de Boa Vista, Paraíba. Revista de Geologia, vol.16 no 1,35-48, 2003

GOPINATH, T. R.; LIMA, A. A. ; SARMENTO, H. J. L. ; COSTA, M. S. A. .Modelamento e lavra de depósitos de bentonita da região de Boa Vista, PB. In: III congresso Brasileiro de Mina a Céu Aberto, 2004, Belo Horizonte. Anais, 2004.

GOPINATH, T. R.; SCHUSTER, H.D; SCHUCKMANN, W.K.1981. Modelo de Ocorrência e gênese da argila bentonítica de Boa Vista, Campina Grande, Paraíba, Revista Brasileira de Geociência 11(3): 185 -192; - São Paulo.Set. 1981.

GREGG, W.T; GARDNER SUMMER, G. Adsorption surface area and porosity. Academic, New York, 1982.

JOSÉ, C. V., Obtenção e caracterização de argilas organofílicas preparadas em laboratório para adsorção de compostos fenólicos visando seu uso no controle ambiental de poluentes industriais, Tese (Doutorado) apresentada ao Departamento de Engenharia Química da Escola Politécnica da Universidade de São Paulo. Orientador Prof. Dr. Pedro M. Buchler. São Paulo, 2003.

KANNAN, S.; DUBEN, A.; KNOZINGER, H., Synthesis and characterization of CuMgAl ternary hydrotalcites as catalysts for the hydroxylation of phenol. Journal of Catalysis, v. 231, pp. 381-392, 2005.

KOJIMA, Y.A.; USUKI, K.; KAWASUMI, A.; OKADA, A.; FUKUSHIMA, Y.; KARAUCHI, T.; KAMIGAITO, O. Mechanical properties of nylon 6/clay hybrid. Journal of Materials Research, v. 6, 1017-1022, 1993.

KOUTROUBRAS, S. D.; PAPAKOSTA, D. K.; DOITSINIS, A. - Adaptation and yielding ability of castor plant (Ricinus communis L.) genotypes in a Mediterranean climate. European Journal of Agronomy, V. 11, p. 227-237, 1999.

LIMA, L. N. Obtenção de biodiesel a partir da mistura dos óleos de milho e algodão usando catalisador homogêneo e heterogêneo. Dissertação (Mestrado). Universidade Federal de Campina Grande, Centro de Ciências e Tecnologia. Campina Grande - PB, Brasil. 2008. 
LIMA. L. N.; CARVALHO, M. W. N. C.; SANTOS, J. C. O.; Estudo da estabilidade térmica e oxidativa do óleo de algodão. Revista Química no Brasil, v. 2, p. 91-96, 2008.

LUZ, A. B. SAMPAIO,J.A. ARAÚJO NETO,M.A. UBM. Usinas de beneficiamento de Minérios do Brasil. União Brasileira de Mineração . Sampaio, J. A; Luz, A.B. da ; Lins , F.A.F. (editores) ,CETEM-MCT, 371-376,2001.

LUZ, A. B ;OLIVEIRA, C. H. Rochas \& minerais industriais. Argila - bentonita. Centro de Tecnologia Mineral- CETEM, MCT, 2008.

Material explicativo fornecido pela empresa DOLOMIL INDUSTRIAL Ltda., 2005.

MENEZES, R.R;NEVES, G.A.; FERREIRA, H.C. Mapeamento de argilas do Estado da Paraíba, Cerâmica vol. 47 n 302,São Paulo 2001.

MENEZES, R.R.; SOUTO,P.M.; SANTANA, L.N.L.; NEVES, G.A.;KIMINAMI,R.H.G.A.;FERREIRA, H.C. Argilas bentoníticas de Cubati, Paraíba, Brasil: Caracterização física-mineralógica, Cerâmica vol 55, n0 334, São Paulo 2009. MEIRA, J. Visa Consultorias, 2001.

MOREIRA, A. G. Preparação e caracterização de nanocompósitos poli(vinil butiral)/argila esmectítica. Dissertação apresentada à Escola Politécnica da Universidade de São Paulo, São Paulo, 2004.

NEUMANN, M.G.; GESSNER, F.; CIONE. A.P.P.; ARTORI, R.A. CAVALHEIRO, C.C.S. Interações entre corantes e argilas em suspensão aquosa, Química nova 23(6) 2000.

NeAmAN, A., PELletieR, M., VILlieRAS, F., Applied Clay Science, 22, 153-168, 2003.

NOVICKIS, R. W.. Síntese de material carbonoso nanoestruturado e aplicações deste em tratamento de água como uma alternativa econômica ,(Monografia) EPUSP 2005. 
PEREIRA, K. R. O, Ativação ácida e preparação de argilas organofílicas partindo-se de argila esmectítica proveniente do Estado da Paraíba ., Dissertação (Mestrado), Orientadora: Meiry Gláucia Freire Rodrigues, Campina Grande- PB, Março de 2003.

PEREIRA, K. R. O; RAMOS VIANNA, M .M.G; RODRIGUES,M.G; VALEZUELA DIAZ, FR. Argila de alguns poluentes orgânicos em argilas organofílicas. Anais do XVI Congresso Brasileiro de Ciências e Engenharia dos Materiais (cd-rom), Porto Alegre- RS, 2004;

PEREIRA, K. R. O;HANNA, R.A.; RAMOS VIANNA, M.M.G; PINTO, C.A.; RODRIGUES,M.G.; VALENZUELA DIAZ, F.R. Brazilian organoclays as nanostructured sorbents of petroleum-derived hydrocarbons. Materials Research, v.8, n.1, p.77-80, 2005.

PETROBRAS, ensaio de viscosificante para fluido de perfuração base água na exploração e produção de petróleo, método N-2604, 1998.

PETROBRAS, ensaio de viscosificante para fluido de perfuração base água na exploração e produção de petróleo, método N-2605, 1998a.

PINTO, W. D.; Resoluções do CONAMA, 2000.

PINTO, G. G.; PIMENTEL, E. C. - Considerações geoeconômicas sobre os Depósitos Argilosos de Boa Vista - Paraíba 4- Distrito Nordeste DNPM / MME, Campina Grande - PB 1968.

PLÁ, J. A.; Perspectiva do biodiesel no Brasil. Indicadores Econômicos FEE, Porto Alegre, v. 30, n. 2, p. 179-190, setembro 2002.

RAMOS, L. P.; In: Anais do Congresso Brasileiro de Soja; Empresa Nacional de Pesquisa Agropecuária; Lodrina, PR, Brasil; 17 a 20 de maio, p 233, 1999.

RAMOS VIANNA, M.M.G. Desenvolvimento de argilas organofílicas visando a remediação de áreas contaminadas por componentes da gasolina. Tese (Doutorado), Departamento de Engenharia Química da Escola Politécnica da Universidade de São Paulo, São Paulo,2005. 
RAY, S. S.; OKAMOTO, M. - Polymer/layered silicate nanocomposites: a review from preparation to processing. Progess in Polymer Science, 28, 1593-1641, 2003.

REZENDE, M. J. C. ;FARIA, R. C. M; OLIVEIRA, C. H.; PINTO, A C.; Avaliação de Catalisador a base de argila na produção de Biodiesel, Anais: $3^{\circ}$ congressos Brasileiro de Petróleo e Gás. Salvador, 2005.

RODRIGUES, M. G. F.et.al. - Obtenção e caracterização de materiais argilosos quimicamente ativados para utilização em catálise. Cerâmica 52, 260-263, 2006.

ROSSI, L. F. S. Química Nova 23, 531, 2005.

SHEM, Y. H. Preparations of organobentonite using nonionic surfactants. Chemosphere, 44, 989-995, 2001.

SHARMASARKAR, S.; JAYNES, W. F.; VANCE, G. F. BTEX sorption by montmorillonite organo-clays: TMPA, ADAM, HDTMA. Water air and soil pollution, $v$. 119 , n. 1-4, p. 257-273, 2000.

SILVA, A.A, RODRIGUES,M.G.F., SILVA, M.C., Caracterização de argilas de Boa Vista- PB pilarizadas, Relatório final de iniciação científica PIBIC/CNPq, Campina Grande- PB, Agosto de 2000.

SILVA, A. A.; KOZIEVITCH, V. F. J.; JOSÉ, C. L. V.; TOFFOLI, S. M.; RODRIGUES, M. G. F.; LIRA, H. L.; FERREIRA, H. C.; VALENZUELA-DÍAZ, F. R. Preparação de argilas organofílicas partindo-se de bentonitas de Campina Grande, Paraíba. Anais do 46ํㅡㄹ Congresso Brasileiro de Cerâmica (CD-Rom), São Paulo-SP, 2002.

SILVA, A.A, LIRA, H.L., Estudo de membranas cerâmicas na separação de água/óleo , (Monografia) UFCG/ANP/PRH-25, Campina Grande- PB, Julho de 2003.

SILVA, A. A. Estudo de argilas Organofílicas destinadas à separação óleo/água. Dissertação (Mestrado) apresentada à Universidade Federal de Campina Grande, Campus I, Campina Grande, 2005. 
SILVA, A. A. Novos catalisadores a base de argilas para a produção do Biodiesel. Tese (Doutorado) apresentada à Universidade Federal de Campina Grande,Campus I, Campina Grande, 2008.

SILVA, A. A. Atividade catalítica em sistemas homogêneos e heterogêneos na produção do biodiesel utilizando a reação de transesterificação a partir do óleo de soja. Dissertação (Mestrado). Universidade Federal de Campina Grande, Centro de Ciências e Tecnologia. Campina Grande - PB, Brasil. Julho de 2007.

SILVA, C. C. C. M. Produção de biodiesel a partir do óleo de soja utilizando Hidrotalcita como catalisador. Dissertação (Mestrado). Escola de Química / Universidade Federal do Rio de Janeiro. Rio de Janeiro - RJ, Brasil. Setembro de 2008.

SING, K. S. W., GREGG, S. J., Adsorption, surface area and porosity, Academic, New York, (1982);

SORA, I. N., ZAMPORI, L., PELOSATO, R., BOTTA, D. DOTELLI, G. and VITELLI, M. - Matrix optimization for hazardous organic waste sorption, Applied Clay Science, 28, 43-54, 2005.

SOUZA SANTOS, S.P., SANTOS, S.H., KIYOHARA, P.K., ZANDONADI, A.R. Estudos de propriedades de argilas esmectíticas (montmoriloníticas) de Campina Grande, Paraíba I. Argilas de diferentes cores das localidades de Bravo. Revista cerâmica, 26 (131) Novembro de 1980.

SOUZA SANTOS, P. Ciência e tecnologia de argilas. São Paulo, Edgard Blücher, v.3, 2 $2^{\mathrm{a}}$ Ed., 1992.

SOUZA SANTOS, P. Tecnologia de argilas, Vol. 1 - fundamentos, Ed. da USP - Ed. Edgard Blücher Ltda, 1975.

SOUZA SANTOS , P - Estudo tecnológico de argilas montmoriloníticas do distrito de Boa Vista, Campina Grande, Paraíba- Tese para concurso à cátedra de Química Industrial, Departamento. de Engenharia Química EPUSP, São Paulo, (Publicação IPT no 862, São Paulo), 1976 . 
Sumário Mineral Brasileiro, Departamento Nacional de Produção Mineral (DNPM). Bentonita, 2007.

Sumário Mineral Brasileiro, Departamento Nacional de Produção Mineral (DNPM). Bentonita, 2009.

TEIXEIRA, V. G., Química Nova, 24, 808-8018, 2001.

TRINDADE, M. H. P. A. Bentonita . In: Sumário Mineral 2000. Departamento Nacional de Produção Mineral, Brasília, p. 31-32, 2000.

VALENZUELA-DÍAZ, F. R.; SOUZA SANTOS, P. de; SOUZA SANTOS, H. A importância das argilas industriais brasileiras. Química Industrial, v. 42, p. 33-37, 1992.

VALENZUELA-DÍAZ, F. R.; Preparação a nível de laboratório de algumas argilas esmectíticas organofílicas. Tese (Doutorado), Departamento de Engenharia Química da Escola Politécnica da Universidade de São Paulo, São Paulo, 1994.

VALENZUELA-DÍAZ, F. R.; SOUZA SANTOS, P. Studies on the acid ativation of Brazilian smectitic clays. Quimica Nova, v.24 ํ3, 2001.

VIEIRA COELHO, A.C; SOUZA SANTOS, P. Argilas Especiais: o que são, caracterização e propriedades. Revisão Quimica Nova, Vol30 № 01, 146-152, 2007.

XI, Y.; DING, Z.; HE, H.; FROST, R. L. Structure of organoclays an X-ray diffraction and thermogravimetric analysis study - Journal of Colloid and Interface Science, 277, 116-120, 2004.

WANG, C. C.; JUANG, L. C.; LEE, C. K.; HSU, T. C.; LEE, J. F.; CHAO, H. P. The effects of exchanged cation, compression, heating and hydration on textural properties of bulk bentonite and its corresponding purified montmorillonite Journal of Colloid and Science, 280, 27-35, 2004.

Disp. em: www.rawell.co.uk/products_technical_information/what_is_bentonite.php Acesso em: Out 2010. 